\title{
Mot bedre vitende
}

\section{i norsk matsektor}

\section{Frode Steen og Ivar Pettersen (red.)}

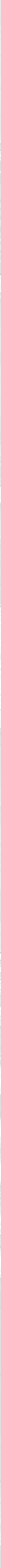



Frode Steen og Ivar Pettersen (red.)

\section{Mot bedre vitende inorsk matsektor}


(C) 2020 Frode Steen, Ivar Pettersen, Richard Friberg, Ivar Gaasland, Erling Hjelmeng, Magne Supphellen og Simen A. Ulsaker.

Dette verket omfattes av bestemmelsene i Lov om opphavsretten til åndsverk m.v. av 1961. Verket utgis Open Access under betingelsene i Creative Commons-lisensen CC BY-ND 4.0 (https://creativecommons.org/licenses/by-nd/4.0/). Denne tillater tredjepart å kopiere, distribuere og spre verket $\mathrm{i}$ hvilket som helst medium eller format under betingelse av korrekt kreditering og at en lenke til lisensen er oppgitt. Lisensen tillater ingen bearbeidelser.

Boka er utgitt med støtte fra NIBIO og NHHs forskningsprosjekt FOOD. FOOD er finansiert gjennom en større forskningsgave fra NorgesGruppen til NHH som er delvis toppfinansiert av Norges Forskningsråd.

ISBN trykt bok: 978-82-02-67183-9

ISBN PDF: 978-82-02-66975-1

ISBN EPUB: 978-82-02-67296-6

ISBN HTML: 978-82-02-67297-3

ISBN XML: 978-82-02-67298-0

DOI: https://doi.org/10.23865/noasp.93

Dette er en fagfellevurdert antologi.

Omslagsdesign: Cappelen Damm AS

Omslagsbilde: Gjøvikgatens kolonial. Foto: Rigmor Dahl Delphin, Oslo Museum, http://oslobilder.no/OMU/OB.RD4572b. Lisens for bildet: CC BY-SA 3.0 NO.

Cappelen Damm Akademisk/NOASP

noasp@cappelendamm.no 


\section{Innhold}

KAPITTEL 1

Mot bedre vitende i norsk matsektor

Ivar Pettersen og Frode Steen

KAPITTEL 2

Annerledeslandet Norge: butikktilgjengelighet og markedskonsentrasjon

i Sverige og Norge

Richard Friberg, Ivar Pettersen, Frode Steen og Simen A. Ulsaker

KAPITTEL 3

Produktivitetsutvikling i norsk matsektor

Ivar Pettersen, Frode Steen og Simen A. Ulsaker

KAPITTEL 4

Priser og marginer i verdikjeden for matvarer

Ivar Pettersen

KAPITTEL 5

Verdikjeden for mat - importbeskyttelse eller konkurranse?

158

Ivar Gaasland

KAPITTEL 6

Hvordan bygge sterke merkevarer med norsk identitet

i dagligvarehandelen?

193

Magne Supphellen

KAPITTEL 7

Det store forhandlingsspillet: vinnere, tapere og reguleringsbehovet

Erling Hjelmeng

Forfatterbiografier 



\title{
KAPITTEL 1
}

\section{Mot bedre vitende i norsk matsektor}

«We always plan too much and always think too little»

Joseph Schumpeter,

Capitalism, Socialism and Democracy

(1947-utg.) forord s. 11

\section{Ivar Pettersen}

\section{Norsk institutt for bioøkonomi, NIBIO}

\section{Frode Steen}

Norges Handelshøyskole, NHH

\begin{abstract}
This chapter summarizes our perspectives on the Norwegian grocery market, and why we have challenged scientific authors to contribute to the present book. Generally, we argue that much of the Norwegian public debate about the functioning of the food supply chain, concentration, market power and the potential competition remedies suggested, is taking place more 'despite of' than 'because of' empirical knowledge. The first part of this chapter summarizes the five primarily empirical articles of this book, drawing the bigger picture on the Norwegian grocery market. These contributions cover questions like: How do the Norwegian market structure and prices compare to other countries' market structure and prices? How has productivity developed over time? How are the Norwegian import restrictions functioning, and how do consumers think about national brands? Given this overview, we discuss potential remedies that might increase efficiency in this market. This discussion is mirroring parts of the sixth article in this book, where the Norwegian competition law and the negotiations in the vertical chain are discussed in more detail.
\end{abstract}

Keywords: Norwegian grocery market, competition challenges, competition remedies, competition policy, food supply-chains

Sitering av denne artikkelen: Pettersen, I. \& Steen, F. (2020). Mot bedre vitende i norsk matsektor. I F. Steen \& I. Pettersen (Red.), Mot bedre vitende i norsk matsektor (Kap. 1, s. 7-34). Oslo: Cappelen Damm Akademisk.

https://doi.org/10.23865/noasp.93.ch1

Lisens: CC BY-ND 4.0. 


\section{Introduksjon}

Det norske matmarkedet preges av sterke meninger og stor medieoppmerksomhet, med debatt om både behovet for regulering og hvordan man eventuelt kan regulere konkurranse mellom kjeder og kontrakter mellom kjeder og leverandører. Mange er involvert i debatten, og det er ikke uvanlig å trekke forskeres uavhengighet i tvil: Forskere engasjert av parter, forskere engasjert av konkurransemyndigheter og andre myndigheter, har alle brakt ulike analyser til torgs (Foros \& Kind, 2018a, 2018b, 2019; Gabrielsen, Moen \& Nilssen, 2020; Gjendemsjø \& Anchustegui, 2017; Hjelmeng \& von der Fehr, 2018; Midttømme, Myklebust, Vikøren \& Grimsby, 2019; Oslo Economics, 2019). Samtidig etterlyser landets politikere mer intensiv virkemiddelbruk. I mai 2018 ba Stortinget om utredning av tiltak som «vil virke konkurransefremmende og legger til rette for nyetablering og fremmer innovasjon i mat- og dagligvaremarkedet, herunder forbud mot prisdiskriminering for dominerende leverandører samt forhold knyttet til distribusjon» (Næringskomiteen, 2018). Det eneste som fremheves som ubevegelig, er importvernet som «må bestå», iflg. næringsministeren i 2018 (Isaksen, 2018).

Uenighet om faglig grunnlag koblet med politiske behov for tiltak gjør det naturlig å forsøke å se nærmere på situasjonsbeskrivelsen. Med unntak av bl.a. en kort rapport fra Konkurransetilsynet som avdekker til dels store forskjeller i rabatter mellom matvarekjeder (Konkurransetilsynet, 2019) og noen andre bidrag, er innspillene i stor grad teoretiske.

Denne boken har et litt annet utgangspunkt, og ønsker å gi et oppdatert bilde av landskapet når det kommer til den empiriske strukturen i det norske matmarkedet, og til dels også hvordan denne ser ut sammenlignet med våre naboland. Gitt den intense debatten har vi utfordret en av de sentrale deltagerne i diskusjonene rundt reguleringer av næringen over mer enn det siste tiåret, professor Erling Hjelmeng, og bedt ham tegne det større bildet når det kommer til hvordan partene i den vertikale kjeden møtes og forhandler. Han diskuterer også hvilke rammer og muligheter som ligger i konkurranseloven, samt ulike muligheter for endret regulering av markedet. 
Resten av boken samler en håndfull forskere som har jobbet med ulike tema vedrørende det norske matmarkedet over lengre tid. Primært har vi ønsket å skape et oppdatert faktagrunnlag rundt hele den vertikale kjeden i matmarkedet. Noen av artiklene er oppdateringer og utvidelse av analyser og tema som har vært gjort i tidligere artikkelsamlinger og rapporter (se f.eks. Gabrielsen \& Pettersen, 2011; Gabrielsen, Steen, Sørgard \& Vagstad, 2013) knyttet til tema som produktivitetsutviklingen på de ulike leddene i matkjeden, prisforskjeller mellom ulike land og effektene av det norske tollvernet. Flere nye funn kommer ut av disse nye, oppdaterte analysene. Boken presenterer også nye bidrag rundt markedsstruktur, butikktilgjengelighet og merkevarens betydning.

Mye av det man visste fra før om norsk matsektor bekreftes, dels med nye data, dels med nye analyser, men boken frembringer også en del nye funn som fortjener oppmerksomhet fra bransjen, medier og myndigheter. I så måte bidrar boken til større visshet og noe mer tilgjengelig kunnskapsgrunnlag, men også konstruktive skisser til styrking av kunnskapsgrunnlaget.

Bokens artikler dokumenterer tre empiriske hovedobservasjoner:

1. Markedsstruktur, konsentrasjon og butikktetthet skiller seg mindre fra våre naboland enn det debatten rundt dagligvaremarkedet gir inntrykk av. Selv om vi har tilsynelatende mange flere butikker enn våre naboland, er butikktilgjengelighet med utgangspunkt i hvor kundene bor (med unntak av hovedstadsområdet Oslo og Akershus) ikke like forskjellig i Sverige og Norge. Tilsvarende vises det at den ofte antatte høye norske opptattheten av «norskhet» i merkevaren kanskje er mindre enn påstått, eller i hvert fall at «norskmerking» er mindre effektiv enn det mange kanskje har trodd, noe som åpner dørene for større innslag av importerte produkter. Sammenlignet med våre naboland er konsentrasjonen på handelsleddet både lokalt og nasjonalt svært mye likere på tvers av skandinaviske land enn det debatten synes å ta inn over seg. En forskjell er imidlertid at muligheten for etablering med relativt små markedsandeler, av store, multinasjonale dagligvarekjeder, er sterkt begrenset i Norge. Det er vanskelig å peke på mer vesentlige årsaker 
til dette enn importvernet for jordbruksvarer og industrielt bearbeidede matvarer.

2. Produktivitetsveksten i matvaremarkedet er i endring. Samlet ser vi i likhet med det vi ser i resten av norsk næringsliv, en redusert arbeidsproduktivitet de siste tiår. Dagligvarehandelen har fremdeles, dels i likhet med primærnæringen, den største produktivitetsveksten i verdikjeden for matvarer. Dagligvarehandelen har vist stor historisk produktivitetsvekst i hele perioden fra 1970 til 2010, men vi ser en reduksjon i årlig produktivitetsvekst etter 2010. Næringsmiddelindustrien har forbedret seg fra et lavt historisk nivå, og er nærmere produktivitetsveksten til handelsleddet etter 2010.

3. Prisutviklingen til konsumenter relativt til våre naboland har vist en forverring siden sist den ble analysert. Maten i Norge er fremdeles dyrest i EØS-området, og ligger mer enn 30 prosent over det våre svenske og danske naboer betaler. Til forskjell fra ti år tilbake er det vanskeligere å forklare forskjellen med generelt høyere, norsk kostnadsnivå for distribusjonstjenester. Et slikt generelt høyere kostnadsnivå ble tidligere illustrert med at andre lett omsettelige konsumvarer som klær og skotøy også var typisk dyrere i Norge. Mens prisforskjellene over tid forsvinner for andre konsumvarer, er forskjellen minst opprettholdt for matvarer. En hovedårsak til den relative forverringen for matvarene de siste tiår ligger i vår bruk av importvernet for norsk jordbruk. Norske myndigheters prioritering av skjermingsstøtte og høye priser har størst direkte betydning for hvorfor prisene blir ekstra høye. I kapittel 5 peker Gaasland i tillegg på uheldige, indirekte virkninger av importvernet. Analysen viser at endringer i prosentvise, relative bruttomarginer tilsier at matindustri og engroshandel har bidratt noe til økende matprisulempe for norske husholdninger, mens detaljistleddet har hatt motsatt effekt.

I sum er det mye som taler for at høy konsentrasjon i dagligvarehandelen er et fenomen vi, som våre naboland, må leve med. Men høyere matvarepriser og fravær av mindre, gjerne internasjonale dagligvarekjeder i er i stor grad drevet frem av norsk jordbruks- og matpolitikk, hvor valg av importvern er et hovedvirkemiddel. Tilsynelatende synes ikke 
denne politikken så langt å ha gått ut over produktivitetsveksten verken i primærproduksjonen eller i norsk detaljhandel med dagligvarer. Detaljhandelen med dagligvarer har tvert imot hatt særlig høy produktivitetsvekst, noe som har bidratt til å dempe prisforskjellen mellom Norge og nabolandene. Det er imidlertid grunner til å være opptatt av bærekraften og holdbarheten i den produktivitetsveksten handelen og primærleddet har fremskaffet, og av styrking av konkurranseevne og produktivitetsvekst $\mathrm{i}$ industrien.

Så langt ser vi få tegn til at dagligvare- og matvarepolitikken har funnet frem til spesielt effektive tiltak. Det er en utbredt oppfatning at tiden er inne for ny politikk og reguleringer som er lite utprøvd. Spørsmålet kan imidlertid være om forbrukere og samfunn forøvrig er minst like tjent med mer konsekvent bruk av bestemmelsene i eksisterende norsk, EØS-basert konkurransepolitikk.

Lite av dette er grunnleggende nye erkjennelser. Noen observasjoner i artikkelsamlingen bringer ny innsikt, f.eks. om forholdet mellom engrosog detaljistledd, og om forholdet mellom konsentrasjon og butikktetthet i ulike regioner i Norge sammenlignet med Sverige. Videre er tilnærmingen og analysen av en annen karakter enn det som har vært presentert tidligere. Dette gjelder f.eks. analysen av strukturforskjeller med vekt på regionale særtrekk, pris- og marginforskjeller og databruken i analysen av produktivitet. Hovedinntrykket er likevel at mye av debatten om dagligvarepolitikk synes å skje «mot bedre vitende», dvs. som om vi hadde en gjennomgående ineffektiv matsektor som skiller seg fra våre naboland langs en rekke dimensjoner. Boken viser på sett og vis at vi er likere på tvers av landene enn hva man kan få inntrykk av. Vi kan ha problemer med fordeling og sosial bærekraft, men evnen til å skille effektivitet fra spørsmål om hvordan «kaken» bør fordeles, er avgjørende for å komme videre $\mathrm{i}$ arbeidet med fremtidsrettede rammebetingelser for verdikjeden for matvarer.

Artiklene forsøker å dokumentere utviklingstrekk som krever stort og detaljrikt datatilfang og grundig statistikkforståelse. Flere steder brukes nye data eller eksisterende statistikk på nye måter; som i analysen av «annerledeslandet» i kapittel 2, produktivitet i kapittel 3, priser og marginer i kapittel 4 og merkevare i kapittel 6. Et av resultatene er at vi ser 
flere svakheter i statistikken. Med den oppmerksomhet matsektoren både får og fortjener, er det grunn til å se nærmere på hvordan statistikk- og metodegrunnlaget for videre analyse av utviklingen i matsektoren kan styrkes.

Boken er kommet til gjennom et samarbeid mellom NIBIO og NHHs forskningsprosjekt FOOD. FOOD er finansiert gjennom en større forskningsgave fra NorgesGruppen til NHH, og er delvis toppfinansiert av Norges forskningsråd. Flere av artiklene bygger på tidligere arbeider utført med finansiering fra Forskningsrådet og jordbrukets og matindustriens forskningsmidler. Boken kan også sees som en oppfølging av temaene $\mathrm{i}$ «Dagligvarehandel og mat»-rapportene fra Norsk institutt for landbruksøkonomisk forskning, NILF (nå NIBIO), spesielt 2011-utgaven. Bokens forfattere har bidratt på grunnlag av vitenskapelige prinsipper med selvstendig ansvar for metodevalg og konklusjoner. Alle kapitler, med unntak av denne introduksjonen, er fagfellevurdert av minst én uavhengig forsker.

I dette kapittelet trekker vi sammen perspektivene fra artiklene. Først utdypes de tre hovedfunnene og empirien som presenteres i boken. Deretter drøftes mulige implikasjoner for dagligvare- og matpolitikken. Boken er tilsvarende organisert; der de fem hovedsakelig empiriske bidragene kommer først, før siste kapittel presenterer forhandlingsspillet mellom kjedene og diskuterer de konkurranserettslige rammenes relevans for norsk matvaremarked. Dette kapitlet presenterer redaktørenes oppfatning av bokens bidrag om norsk matvaremarked. Alle de andre kapitlene er selvfølgelig de respektive artikkelforfatterne ansvarlige for.

\section{Konsentrasjon og butikktetthet er mye som hos våre naboer, og det at produktet er merket «norsk» synes ikke så viktig}

\section{Konsentrasjonsgraden om lag som i andre land}

I kapittel 2 analyserer Friberg, Pettersen, Steen og Ulsaker konsentrasjon, markedsandeler og butikktilgjengelighet i primært Norge og Sverige, men konsentrasjonsanalysen ser også på Finland og Danmark. I likhet 
med våre naboland har Norge høy konsentrasjon i detaljhandelen av dagligvarer. Vi skiller oss ikke ut på nivå, men vi har hatt en sterkere vekst $\mathrm{i}$ konsentrasjonen det siste tiåret.

Dekomponerer vi konsentrasjonen regionalt finner vi at mens den høyeste konsentrasjonen i Sverige er i mindre sentrale len med lav befolkningstetthet, er konsentrasjonen i Norge høyest i de mer folkerike fylkene på Østlandet. Ser vi på de underliggende markedsandelene er Norge delt. NorgesGruppen dominerer sør for Trøndelag, mens Coop er dominerende fra Trøndelag og nordover. Rema 1000 er relativt jevnt til stede i alle landsdelene. Sammenligner vi med Sverige, er det kun de to største aktørene som er etablert i de mindre folkerike områdene i Nord-Sverige. I så måte skiller Norge seg ut ved å ha full distribusjon i alle fylker av alle de tre største kjedene.

Generelt er konsentrasjonen i Norge, Sverige og Finland høyest, og langt over det som EU oppfatter som bekymringsfullt, på tvers av næringer og sektorer. Dette er samtidig de nabolandene som har klart dyrest og mest krevende distribusjon, noe som spesielt gjelder for Norge. Der Norge skiller seg ut for øvrig, er ved fraværet av utenlandske kjeder som Lidl og Aldi, som typisk er til stede i våre naboland.

Friberg m.fl. (kapittel 2) og Gaasland (kapittel 5) argumenterer, i likhet med tidligere studier som Oslo Economics/Oeconomica (2017), for at dette primært skyldes at det ikke finnes importvern mellom EU-land, mens norsk importvern overfor EU i vesentlig grad hindrer import. Kjeder som Lidl og Aldi kan dermed i større grad dra nytte av sin internasjonale størrelse i andre land. Selv i Finland, der de to store kjedene (K- og S-gruppen) fullstendig dominerer, har Lidl doblet sin tilstedeværelse fra 2011 til 2018, og vokst fra 5 til 10 prosent av markedet. I Sverige har Lidl (om enn fra et lavt nivå) økt sin andel med 47 prosent over samme periode, og også i Danmark har Aldi og Lidl økt sin tilstedeværelse over perioden.

Lokal tilstedeværelse av disse internasjonale kjedene endrer også markedet $\mathrm{i}$ andre dimensjoner. Markedet differensieres gjennom import av produkter som vi typisk ikke finner hos de store nasjonale aktørene og andre driftskonsept (eksempelvis mer gjennomførte «hard core discount»-konsepter). Større grad av produktdifferensiering og muligheten for aktører som Aldi og Lidl til å «importere» sin forhandlingsstyrke 
påvirker dermed forhandlingsspillet mellom kjeder og leverandører. Trolig begrenser dette muligheten større nasjonale leverandører har til å kunne prisdiskriminere mellom kjeder, slik vi nylig har sett tall for i Norge. Over tid kan dermed etableringsmulighetene for internasjonale dagligvareaktører med egne leverandørrelasjoner innebære større muligheter for mer intensiv kamp om markedsandeler og strukturendring.

\section{Bedre butikkdekning}

Butikktilgjengelighet er så langt i litteraturen mest typisk beregnet som forholdet mellom antall butikker og antall innbyggere. Antall butikker har gått kraftig ned, men like fullt har Norge flere butikker i forhold til folketall enn det vi ser hos våre naboer. De norske butikkene er også mindre - gjennomsnittsbutikken i Norge er nesten 40 prosent mindre enn gjennomsnittsbutikken i Sverge.

Artikkelen til Friberg m.fl. i kapittel 2 presenterer nye mål på butikktilgjengelighet, der man benytter butikkers og kunders plassering regionalt og detaljert beregner butikktilgjengelighet lokalt der kundene bor. Her viser man at til tross for at Sverige har halvparten så mange dagligvarebutikker som Norge i forhold til befolkning, er landene overraskende like når det kommer til lokal butikktilgjengelighet. Mens innbyggeren i det mest typiske norske fylket har tilgang til 12 butikker innenfor 10 minutters reiseavstand, har innbyggeren fra det mest typiske svenske lenet tilgang til 7 butikker.

Der Norge skiller seg kraftig ut er i hovedstadsregionen. Her har Norge veldig stor butikktetthet både om vi sammenligner med andre fylker og len eller med hovedstadsområdet i Sverige. Innenfor 10 minutters reiseavstand har osloenserne 137 butikker å velge mellom. Selv når vi ser på gjennomsnittsinnbyggeren i Oslo og Akershus samlet (som er mer sammenlignbart med Stockholm len), har gjennomsnittskonsumenten 80 butikker innenfor denne radiusen. En Stockholmer har til forskjell bare 35 butikker å velge mellom. Med tanke på at bosettings- og urbaniseringsstrukturen neppe er så forskjellig mellom de to hovedstadsregionene, tyder dette på overetablering av dagligvarebutikker i den norske hovedstadsregionen. Tar vi hensyn til at de fleste kunder fra denne regionen bor 
mindre enn 90 minutter fra nærmeste svenske butikk med store vareutvalg og langt lavere priser, forsterkes konklusjonen om overetablering. Sammenligner vi gjennomsnitt på tvers av fylker og len, øker gjennomsnittlig antall butikker innenfor 10 minutters reiseavstand for begge land som følge av den høye tettheten i hovedstedene. Men der landssnittet for de svenske lenene i Sverige uten Stockholm går fra 10 til 9, går det for de norske fylkene fra 20 til 12.

Artikkelen gjør også en sammenligning av Nord-Sverige og NordNorge: to områder som er svært like i areal og folketetthet, men der det er mer enn dobbelt så mange butikker på norsk som på svensk side av grensen. På tross av denne forskjellen har gjennomsnittsinnbyggeren på begge sider tilgang til omtrent like mange butikker (6-7) innenfor 10 minutters reisetid.

Ser vi bort fra hovedstadsregionen, viser analysen av butikktetthet at det er nødvendig med mange flere butikker for å kunne gi nordmenn like god tilgjengelighet som svensker. Dette skyldes at vi har en helt annen topografi og bosettingsmønster koblet med et veinett som gjør at det simpelthen kreves flere butikker for å nå «hjem» til norske husholdninger. Dette betyr også at det blir langt mer effektivt med større og mer kostnadseffektive butikker i Sverige.

\section{Norsk merkevarelojalitet}

Merkevarer er en mulig kilde til markedsmakt, og det er kamp om kontroll med merkenavn i verdikjeden for matvarer. Spørsmålet om merkevarenes betydning for kundelojalitet er derfor like viktig for å forstå konkurransen i matmarkedet som i andre markeder for konsumvarer.

Norske konsumenter er trolig mer opptatt av norske merkevarer i daglighandelen enn hva svensker og dansker er av sine nasjonale merker. Noe av dette skyldes nok at et høyere tollvern har gjort norsk økonomi langt mer lukket når det kommer til mat. Noen av kommentatorene som vurderte Lidls exit i Norge pekte på at norske kunder var overraskende skeptiske til nye og annerledes produkter som typisk ble ført av Lidl. Tilsvarende har Norge en lav andel med private merkevarer, dvs. kjedenes 
egne merker, sammenlignet med andre nasjonale dagligvaremarkeder, noe som nok også kan tilskrives et mer lukket matmarked.

Samtidig har vi sett økt bransjeglidning, der norske merkevarer får konkurranse gjennom fremveksten av såkalte «dollar stores» (eksempelvis Europris og nå fremveksten av Dollarstore-kjeden). Her selger man gjerne produkter med mindre kjente merkenavn eller uten merkenavn i det hele tatt. Dette tyder på at den norske kunden kanskje er mer bevegelig enn det man lenge har tenkt.

For bedre å forstå merkevaren og dens viktighet, har Magne Supphellen i kapittel 6 beskrevet hva som driver folks preferanser og tanker rundt merkevaren, herunder hvilke assosiasjoner som typisk knyttes til merkevaren og hvilken nytte som driver merkepreferansene. Søkelyset rettes mot behovet for å forstå hvordan generisk markedsføring påvirker merkevarens norske identitet, og hvordan dette kan gjøres på en god og verifiserbar måte.

Videre diskuteres den nyeste forskningen på feltet, før Supphellen empirisk viser hvordan den generiske merkeordningen til stiftelsen Matmerk («NytNorge-merking» - en kvalifisering og tilleggsmerking av norske produkter) påvirker oppfatninger om «norskheten» av den aktuelle merkevaren. Han beskriver et simulert butikk-eksperiment med 300 deltagere og tre typer. Resultatene var entydige: NytNorge-merket hadde ikke signifikant effekt på valg av produkt for noen av de ni norske produktmerkene i testen.

Denne typen forskning viser dels at vi vet for lite om generisk effekt av markedsføring og produkters merkevarestyrke, men antyder også at konsumenter kanskje er mindre opptatt av nasjonalitet enn vi har tenkt. Noe som eksempelvis kan forklare at norske kunder nå tilsynelatende velger vaskepulver $\mathrm{i}$ «grå» forpakning fra nye «dollar stores» like lett som OMO fra Lilleborg. Å forstå merkevareeffekter er derfor viktig for å forstå fremtidig konkurranse i matvaresektoren. 


\section{Ingen klare tegn til ineffektivitet, men noe forskjell mellom industri og handel, engros og detalj}

I kapittel 3 analyserer Pettersen, Steen og Ulsaker endring i arbeidskraftens produktivitet over tid for tre ledd innenfor norsk matmarked: næringsmiddelindustrien, detaljist- og engrosleddet. Siden 1970-tallet har veksten i arbeidsproduktiviteten i Norge vært ganske jevn, men det siste tiåret viser fallende vekst for næringslivet inklusive matsektoren. Den brede trenden i produktivitetsveksten tyder på at det er sammenheng mellom produktivitetsvekst på tvers av næringer. Grunnen kan bl.a. være endrede, generelle rammebetingelser, endringer i arbeidskraftens sammensetning og brede teknologiendringer.

Matsektoren, som norsk næringsliv ellers, opplever samlet en svekkelse av produktivitetsveksten for perioden 2008 til 2017 sammenlignet med foregående tiår. Men på lengre sikt har næringsmiddelindustrien forbedret seg fra et lavt historisk nivå, og har nå årlig arbeidsproduktivitetsvekst på mellom to og tre prosent. Sjømatindustrien trekker opp matindustriens produktivitetsvekst. Lengre nede i den vertikale kjeden har varehandelen totalt, hatt en stor historisk produktivitetsvekst på årlig mer enn fem prosent i denne lange perioden frem til 2010, men opplever nå et markert fall i årlig produktivitetsvekst til noe over tre prosent etter 2010.

Primærproduksjonen har også relativt sterk produktivitetsvekst, men igjen skiller sjømatsektoren seg ut. Akvakultur har hatt meget høy produktivitetsvekst, men har et markert fall i arbeidsproduktivitetsvekst de seneste årene.

For å finne produktivitetsveksten i dagligvarehandelen er det nødvendig med egne beregninger hvor prisindeksene har avgjørende betydning. Prisveksten ut mot forbrukerne har vært lavere enn inn mot engroshandelen med matvarer. Det er noe av grunnen til at artikkelen viser at dagligvarehandelen har hatt relativt høy produktivitetsvekst. Samtidig er produktivitetsveksten også en årsak til at handelsleddet har dempet prisstigningen ut mot forbrukerne. Artikkelen viser også at det er høyere 
arbeidsproduktivitetsvekst på detaljistleddet enn på engrosleddet. Samtidig er engros- og detaljhandel i stor grad vertikalt integrert, slik at prisdannelsen mellom de to leddene kan sees som resultat av intern styring i virksomheter med varierte former for vertikal integrasjon og kontroll, mer enn som resultat av konkurranse og kjøper- eller selgermakt.

Forskjellen mellom dagligvarehandelen og industrien samsvarer med forskjellen mellom industri og varehandel generelt. Det tilsier at hovedforklaringen neppe finnes i forskjellene mellom matindustri og detaljleddet spesifikt i matsektoren. Det er mer sannsynlig at vi i hovedsak observerer generelle forskjeller mellom industri og tjenesteytende næringer som handel.

Forfatterne bruker en del plass på å kontrollere for utviklingen i sjømatsektoren, som er i ferd med å få en avgjørende betydning for produktivitetsutviklingen for næringsmiddelindustrien. Produktivitetsutviklingen skiller seg så vidt mye mellom næringsmiddelindustri generelt og sjømat at man bør analysere disse separat, noe forfatterne prøver å ta hensyn til. Det er for eksempel stor forskjell på prisutviklingen for innsatsvarer og handelsvarer til norsk matindustri og dagligvarehandel sammenlignet med den samlede førstehånds- eller engrosomsetningen av matvarer i Norge inklusiv all sjømat.

\section{Matvarer er dyre i Norge, og vi har et importvern som i stor grad understøtter dette}

\section{Prisutviklingen}

I kapittel 4 analyserer Pettersen konsumentpriser på matvarer og hvordan disse har utviklet seg siste tiår. Generelt har det skjedd en forverring relativ til prisutviklingen i Danmark og Sverige. I 2018 er gjennomsnittsprisen i Norge 32 prosent over snittet av våre naboland. I 2005 var forskjellen 22 prosent. Prisforskjellen for klær og skotøy har imidlertid sunket fra 22 prosent til minus en prosent (kapittel 4, figur 6). Med andre ord, mens man både i 2005 og 2010 kunne antyde at en generell merkostnad i distribusjon av lett omsettelige konsumvarer kunne forklare en stor del 
av prisforskjellen overfor nabolandene i matsektoren (Pettersen, Kjuus \& Lavik, 2011), er dette ikke lenger tilfellet.

Artikkelen viser betydningen av forskjeller i merverdisatser og skjermingsstøtte - dvs. importvernet - til jordbruket, og observerte prisforskjeller i andre konsumvaremarkeder enn for matvarer. Analysen viser mulige forklaringer på noe av prisforskjellen mellom Norge og nabolandene, og resulterer i et stort og voksende uforklart restledd.

I andre del av analysen bruker Pettersen regnskapsdata til å se om prisforskjellen, spesielt endringer i prisforskjellen, kan tilskrives bruttomarginer på industri-, engros- og detaljistleddet. Funnene viser at endringer i prosentvise, relative bruttomarginer tilsier at matindustri og engroshandel har bidratt noe til økende matprisulempe for norske husholdninger, mens detaljistleddet har hatt motsatt effekt.

Blant de faktorene som kan tallfestes, fremstår skjermingsstøtten til jordbruket som det største bidraget til økte prisforskjeller de siste årene. Siden år 2000 har skjermingsstøtten økt, mens den fra samme år er redusert med om lag to tredeler for EU-jordbruket. I analysen bruker Pettersen EUs skjermingsstøtte i prosent av verdensmarkedsverdier for sammenligning med norsk skjermingsstøtte. Dette impliserer at skjermingsstøtten i 2017 vil utgjøre 5 prosent av internasjonal markedsverdi i Sverige/Danmark mot 47 prosent for Norge. Skjermingsstøtten i Norge er altså ti ganger høyere enn i EU. Mens EU har fjernet 80 prosent av skjermingsstøtten siden 2000, har Norge fjernet vel 40 prosent. Det hører med til bildet av importvernet at skjermingsstøtten har falt de to siste årene, men da som følge av redusert kroneverdi, og ikke endret politikk.

\section{Det norske importvernet}

Uttalelsen til næringsministeren i begynnelsen av dette kapittelet, kan settes i sammenheng med en særegenhet ved den akademiske og politiske debatten i Norge om konkurransen i verdikjeden for mat: Nemlig at importvernet tas for gitt, og ikke drøftes spesifikt i relasjon til konkurranseutfordringene. Til sammenligning fremgår det av sammenligningen mellom politikken i EU og Norge at politikk som skaper store 
prisforskjeller mellom internt marked og omverden i stor grad er forkastet i EU. Dette skyldes ikke at det ikke finnes alternativer, som f.eks. målrettede tilskudd over statsbudsjettet. I sin artikkel drøfter Ivar Gaasland i kapittel 5 hvordan importvernet kan tenkes å påvirke konkurranse, samarbeidsformer og effektivitet i verdikjeden. En indirekte virkning av beskyttelsen mot utenlandske matvarer er høy konsentrasjon og svak konkurranse på leverandørleddet. Mangelen på utenlandske alternativ på leverandørsiden bidrar igjen til å skape etableringshindringer i dagligvaremarkedet. Når en utenlandsk dagligvarekjede hindres i å ta med seg sitt nettverk av leverandører, er det lite attraktivt å etablere seg i Norge.

Importvernet har også andre kostnader. Fravær av åpen, internasjonal handel gjør at norsk matsektor går glipp av flere mulige effektivitetsgevinster. Gevinster med handel er spesielt store for små land med lite variert ressursgrunnlag. Når hjemmemarkedet er for lite til å ta ut gevinster gjennom stordriftsfordeler og spesialisering, blir man avhengig av eksport for å oppnå effektiv produksjon, som vi ser eksempelvis for fisk. Gevinster ved næringsintern handel, dvs. handel som i særlig grad utnytter spesialiseringsfordeler og produktdifferensiering, utnyttes i liten grad når det er handelshindringer. Til tross for at næringsmiddelindustrien typisk kjennetegnes ved stordriftsfordeler i produksjonen og produktdifferensiering overfor handelsledd og forbrukere, blir det lite import av matvarer som står i et konkurranseforhold til norske jordbruksvarer.

Gaasland argumenterer også for at både jordbrukspolitiske mål og matsikkerhet kan ivaretas gjennom å reformere importvernet i en kombinasjon med kompenserende overføringer og subsidier. Spesielt argumenterer han for at et effektivt tiltak for å sikre økt konkurranse i verdikjeden kan være å redusere tollsatsene på jordbruksvarer så mye at det muliggjør løpende import innenfor alle produktkategorier. I dag er en rekke produkter overbeskyttet i den forstand at tollsatsene er så høye at all import utestenges.

En reduksjon i satsene slik at man på marginen ville få et elastisk, reelt tilbud av import, og kanskje i praksis en liten importandel, ville konkurranseutsette leverandørindustrien i større grad enn i dag, og muliggjøre etablering av internasjonale dagligvarekjeder som da vil få reelle utsidealternativ. Som vist i artikkelen om konsentrasjonsstruktur i kapittel 2, 
ville vi antagelig hatt om lag samme konsentrasjonsgrad, men også innslag av internasjonale detaljistkjeder. På leverandørsiden vil bønder og matindustri potensielt kunne få noe sterkere insentiver til produktutvikling og tydeliggjøring av fordeler med norske produkter. Eksempelvis produserer Norge sine grønnsaker med lavere bruk av sprøytemidler, og det stilles krav til særlig høy dyrehelse i produksjon av husdyrprodukter. Satt i sammenheng med klimaproblematikk, vil dette kunne gi merverdi til en sterkere merkevareprofilering.

Ytterligere omlegging fra skjermingsstøtte via importvernet til støtte over statsbudsjettet vil samtidig redusere behovet for råvarekompensasjon (RÅK-ordningen). Denne kompenserer konkurranseutsatt norsk matvareforedling for ulempen av dyrere norske råvarer i produksjonen, og andre byråkratiske ordninger.

Videre argumenterer Gaasland at en slik endring vil signifikant redusere konsumentprisene, og ha som sideeffekt en effektivisering av industrien. Kombinert med tilpassede subsidier og overføringer til primærnæringen, ville en slik effektivisering trolig være samfunnsøkonomisk lønnsom.

Mye taler for at en slik reform også ville øke variasjonen av varer og gjøre norsk dagligvarehandel mer lik det vi ser hos våre naboer. Boken har ikke analysert vareutvalg eller kvalitet. Spesielt vareutvalg har vært et mye diskutert tema i Norge. Flere rapporter fra SIFO (Alfnes \& Dulsrud, 2016; Alfnes, Schjøll \& Dulsrud, 2019) har analysert vareutvalget i Norge, og gjennomgående påvist at dette er gjennomsnittlig mindre enn det vi ser hos våre naboer. Menon Economics har også sett på dette, og har som hovedpoeng at sammenligner man likt-med-likt, dvs. butikker av lignende størrelse og utseende på tvers av land, er forskjellene mye mindre (Skogli \& Jenssen, 2016).

Utfordringen med denne typen sammenligninger er åpenbart at strukturforskjellene er store (jf. kapittel 2 «Annerledeslandet Norge»). Gjennomsnittsbutikkene i Norge er mye mindre enn i Sverige, og dermed er det ingen overraskelse at svensk gjennomsnittsutvalg også er større. På den annen side, eksistensen av større butikker avspeiler også det svenske konkurranse- og preferansebildet. Når Menon sammenligner Norge og Sverige, sammenligner de mer typiske norske butikker med mindre 
typiske svenske butikker. SIFO sammenligner på sin side ulike butikker på tvers av land - men de sammenligner mer representative butikker fra hvert av landene. I sum er det dermed ikke rett frem å konkludere denne typen sammenligninger. I tråd med konklusjonene rundt priser og effektivitet er det imidlertid mye som taler for at en lettelse i importvernet langs de linjene som Gaasland argumenterer for, trolig også ville økt variasjonsbredden i norske dagligvarer.

\section{Behov for en politikk som forbereder fremtiden og sikrer det vi har}

Ovenfor har vi oppsummert og oppdatert mye av det som må kunne kalles norsk «matmarkedstopografi». Som vi skrev innledningsvis er flere av observasjonene ikke nye, men vi mener analysene bidrar til både stadfesting, presisering og nyansering. I særdeleshet setter de norsk matmarked inn i et noe større perspektiv. En del klare konklusjoner kommer frem:

- Konsentrasjonen på handelsleddet er høy, men her er vi ikke så forskjellige fra våre naboland.

- Norge har ikke innslag av internasjonale kjeder - her er vi forskjellig fra våre naboland.

- Norge har høyere butikktilgjengelighet enn Sverige, men dette skyldes først og fremst spesielt stor forskjell mellom hovedstadsregionene. Med unntak av hovedstadsområdet Oslo/Akershus er butikktilgjengeligheten fortsatt høyere i Norge, men forskjellen er moderat.

- Produktivitetsutviklingen i matvaremarkedet er ikke veldig forskjellig fra det vi ser i annet norsk næringsliv det siste tiåret, men veksten $\mathrm{i}$ arbeidsproduktiviteten er stadig høyere i detaljhandel med dagligvarer enn i både matindustri og engroshandel med dagligvarer.

- I siste tiår har konsumentprisene i Norge økt (til dels kraftig) i forhold til våre naboland, mens det har vært motsatt utvikling for andre lett omsettelige konsumvarer. 
- Mens detaljistkjedeleddet har virket prisdempende på siste tiårs prisutvikling, har industrien og engroshandelen til dels vært prisdrivende over perioden.

- Viktigste prisdriver har imidlertid vært en substansiell økning i importvernet.

Særlig interessant er det at siste punkt også er en underliggende forklaring for det som er av både strukturelle svakheter og prisulemper. Ser vi nærmere på importvernet, viser Gaasland i kapittel 5 at mye av forklaringen ligger i at man velger å fullstendig beskytte det norske markedet gjennom å holde tollsatsene på så høye nivå at import av jordbruksråvarer og mange viktige kategorier bearbeidede varer er utenkelig.

Denne beskyttelsen gjør at det norske matvaremarkedet blir kunstig lite i størrelse, hvor både produsent- og kjedeledd er mer konsentrert enn det vi ønsker oss. Når ekstramarginene og ekstrakostnadene i norsk varehandel er konkurrert vekk (og i dag nærmest er borte) for lett omsettelige konsumvarer som klær og sko det siste tiåret, illustrerer det at lukketheten i matmarkedet skaper konkurranseproblemer. Den samme lukketheten gir rom for prisdiskriminering på tvers av dagligvarekjeder, den gir oss færre produkter og den gir oss trolig færre aktører.

Selv om det tilsynelatende hersker tverrpolitisk enighet om at importvernet skal bestå, virker det merkelig at man heller ikke skal diskutere graden av importvern og hvordan man implementerer dette. Er det politisk villet at importvernet gjennom siste tiår har økt i en slik utstrekning at prisforskjellene mellom oss og våre nærmeste naboland er forverret med nesten 50 prosent? Er måten vi implementerer importvernet på den beste samfunnsøkonomisk sett? Kan vi omforme importvernet slik at vi både beskytter norsk landbruk og samtidig oppnår lavere priser og bedre produktivitet?

Alt dette diskuteres i mer detalj av Gaasland. Han argumenterer for at en bedre løsning ville være å fjerne overbeskyttelsen i tollsatsene - altså redusere tollsatsene slik at prisen man må betale for utenlandske produkt kommer mye nærmere norsk markedspris. Selv bare en marginal importandel (heller enn null) ville effektivt begrense handlingsrommet i den nasjonale prissettingen, og åpne for import for nye matvarekjeder 
med internasjonal forankring. Gaasland mener det vil redusere muligheten for prisdiskriminering, som dagens lukkede matvaresystem tillater. Det ville trolig endre insentiver til produktdifferensiering og merkevarebygging for norske produkter (jf. analysen til Supphellen i kapittel 6), og produktutvalget ville økt. Prisene ville sannsynligvis også bli lavere.

I den grad dette ville påvirke landbruket negativt, vil effekten trolig være marginal og mulig å kompensere med direkte overføringer Og, som Gaasland diskuterer i detalj, matsikkerheten ville kunne ivaretas like fullt.

\section{Importvernet er også politisk bekvemt}

Subsidier kan enten betales over skatteseddelen eller av konsumentene gjennom kunstig høye priser. I 2015 var skjermingsstøtten, som Pettersen viser, nær nivået for hele landbruksstøtten over statsbudsjettet og skjermingsstøttes finansieres av importvernet. I stedet for at norsk primærproduksjon støttes via beskatning og statsbudsjett, må konsumenter og foredlingsindustri betale for landbruksnæringen ut fra eget forbruk. Vi har med andre ord valgmuligheter mellom virkemidler for å opprettholde norsk landbruk. Man kan derfor spørre seg om hvorvidt noe av grunnen til at man politisk har fredet importvernet, skyldes at den langt vesentligste delen av landbruksstøtten på denne måten «usynliggjøres» og unndras årlige politiske budsjettdebatter.

Budsjettdynamikken i norsk statsforvaltning gjør at ordninger som ikke går gjennom vanlig stortingsbehandling, men implementeres gjennom kryss-subsidierigsløsninger, typisk får mindre oppmerksomhet, både fra politikere, men også fra medier. Noe av grunnen er at tallene er vanskeligere tilgjengelige: Hvor mye subsidierer byboerne i sentrale strøk befolkningen i regional-Norge når det kommer til post-tjenester, eller for den del regionale flyplasser? Når tallene blir «usynlige» blir også oppmerksomheten lavere, og den politiske behandlingen blir potensielt mer «overfladisk». Tilfeller der mer eller mindre godt skjulte subsidier viser seg også mer robuste mot endring, enn sine mer synlige alternativer er velkjent fra andre deler av samfunnet. 
Skjermingsstøtten har sin klare parallell med hvordan store overskudd fra noen veldig få store flyplasser betaler for tilsvarende store underskudd for et veldig stort antall små flyplasser gjennom Avinor-systemet. Kostnadene med å drive (også politisk villet) distriktsvennlig samferdselspolitikk skjules for norske skattebetalere. I slike system er det vanskelig å få til endring. Illustrerende nok tar det mange år før man klarer å endre opplagt ulønnsom lufthavnstruktur. ${ }^{1}$ Vi tror derfor at en gradvis overgang mot et system med mer direkte subsidier til landbruket, bedre vil synliggjøre politiske valg, og veldig sannsynlig øke endringstakt og effektivitet.

\section{Hvis vi ikke skal «røre» importvernet blir alternative tiltak fort «second best»}

Istedenfor å gjøre noe med det som fremstår som et fundamentalt spørsmål - et lukket og lite norsk matvaremarked hvor det er stordriftsfordeler i råvarebearbeiding og distribusjon, og løse følgeproblemene av denne lukketheten - diskuteres i dag en rekke forslag til tilleggs- og konkurransereguleringer i matvaremarkedet. Alle løsninger har det til felles at de er såkalte best mulige løsninger under lite gunstige betingelser, dvs. «second best»-løsninger. De skal løse et reelt konkurranseproblem gjennom å styre markedseksternaliteter som følger av at vi har skapt økt risiko for et ineffektivt marked gjennom å «lukke» det norske matmarkedet. Det de ulike forslagene dermed har til felles, er at de gjennom å løse noe ofte skaper nye utfordringer. Eller, tiltak som begrenser ett problem, men som typisk kan skape nye problem. I tillegg har mange av tiltakene store administrative kostnader ved seg.

Flere slike tiltak diskuteres i detalj i siste kapittel av boken, der Hjelmeng viser det større bildet når det kommer til mulighetsrom for konkurranseregulering innenfor dagens rammeverk, men også peker på

$1 \quad$ Fagernes lufthavn ble lagt ned i 2018. Fagernes betjente et veldig lite antall kunder, og krevde Avinorsystemets langt største subsidier. I 2009 ble enkeltbilletter subsidiert med mer enn $4000 \mathrm{kr}$. Selv i 2015 flydde det knapt 6000 passasjerer fordelt på mer enn 2000 flybevegelser på Fagernes. 
utfordringer. Forslagene som kanskje har vært mest fremme i diskusjonen av mulige nye og ikke enda vedtatte reguleringer er: ${ }^{2}$

- Ekstra begrensninger på vertikalt samarbeid, herunder ny lovregulering av leverandørers mulighet til å diskriminere mellom dagligvareaktører.

- Pålegge dominerende distributører plikt til å distribuere ulike leverandørers og detaljistkjeders varer på ikke-diskriminerende vilkår.

- Sterkere regulering og kontroll av dagligvarekjedenes eiendomstransaksjoner.

- Maksimalgrenser for markedsandeler.

Alle tiltakene har det til felles at de løser noen problemer, men åpner for andre potensielle problemer. Under går vi gjennom de foreslåtte tiltakene, og diskuterer kort noen av utfordringene med disse.

\section{Ekstra begrensninger på prisforhandlinger og vertikalt samarbeid}

Her foreligger en rekke utredninger som vi ikke kan oppsummere fullt ut her. ${ }^{3}$ Det synes riktig å slå fast at avhengig av sentrale forutsetninger om viktigheten av kjedenes utsidealternativer, hvor reelle disse er, modellstruktur (lineære vs. ikke lineære kontrakter osv.), vil en slik regulering kunne gi både høyere og lavere priser til konsument. Generelt er noe av avveiningen i disse diskusjonene sentrert rundt i hvilken grad «lik innsatsfaktorpris» til kjedene motvirker konsekvensene fra at konkurranseeffektene av forhandlingene fjernes. Både kjeders og leverandørers forhandlingsmuligheter og -insentiver endres av forbud mot prisdiskriminering. Altså, man fjerner ett problem (etableringshindringer og skjev konkurranse som følge av ulike innkjøpspriser), men skaper et annet: svekkede motiv for å forhandle om lave innkjøpspriser, noe som kan gi høyere priser til alle. I tillegg argumenterer flere (se f.eks. Hjelmeng

2 Hjelmeng diskuterer også innføringen av Lov om god handelsskikk, som er bestemt implementert i 2020.

3 Se referansene i første avsnitt. 
i kapittel 7) for at de administrative utfordringene ved et slikt forbud er store.

At den fagøkonomiske debatten ikke gir en klar konklusjon, er i seg selv et tegn på usikkerhet og et argument for forsiktighet. Jo mer inngripende en regulering er, jo mer sikkerhet bør foreligge ved en eventuell implementering. Det er opplagt en bekymring at prisforskjellene mellom kjeder fra leverandør, i hvert fall for enkeltprodukter og enkeltleverandører, er store (Konkurransetilsynet, 2019). Det er sannsynlig at store forskjeller i innsatspriser gir vridninger i kjeders markedsposisjon. I så måte er det også usikkerhet rundt langsiktige konkurranseeffekter av å unnlate å gripe inn. På den annen side er det mye som taler for at en kraftigere sanksjonsbruk med støtte i konkurranseloven vil dekke samme formål og kan være et like egnet virkemiddel som en tilleggslov med forbud mot diskriminerende vilkår.

\section{Pålegge dominerende distributører forpliktelse om åpne distribusjonstjenester}

Pålegg om såkalt «åpne distribusjonstjenester» betyr at distributør må stille systemet til disposisjon for tredjeparter på ikke-diskriminerende vilkår. Et slikt påbud ligner på ovennevnte forbud mot prisdiskriminering. Begge tiltak skal hindre konkurransebegrensende forskjeller i konkurransevilkår for små og store dagligvareaktører.

Et slikt påbud kan hente sin modell fra teleregulering der myndighetene mener at markedsstrukturen gjennom store nettverk og dominerende aktører krever såkalt ex-ante regulering. Her pålegges dominerende nettverksoperatører ekstra forpliktelser for å oppnå virksom konkurranse, eksempelvis ved at dominerende foretak (i Norge gjelder dette for Telenor) er pålagt å tilby konkurrenter leietilgang til eget nett på ikke-diskriminerende vilkår (ekomloven, 2003). Altså, en konkurrent skal få kjøpe tilgang til nettet på vilkår som ikke avviker for mye fra dominerende aktørs egen sluttbrukervirksomhets vilkår. Reguleringen setter så opp vilkår for hvordan dette skal gjøres, og eventuelt for hvordan dette kan etterprøves. I dagligvaremarkedet er argumentet at så lenge det kan bli prohibitivt dyrt å bygge opp distribusjon i hele Norge, bør ASKO, som 
mulig dominerende aktør i distribusjonsmarkedet, pålegges å distribuere matvarer for alle som måtte be om det, på ikke-diskriminerende vilkår.

Grunnlaget for et slikt påbud virker imidlertid usikkert. For det første synes ikke det vi observerer i Norge uten videre å tilsi at etableringshindringer og stordriftsfordeler i distribusjon er et konkurranseproblem for produktiviteten eller prisutviklingen. Per i dag betjener allerede ASKO den fjerde kjeden, Bunnpris, som så vidt vi forstår har samme betingelser som NorgesGruppens egne butikker. Bunnpris har tidligere brukt distribusjonssystemet til Remagruppen, og så lenge aktører som Bunnpris kan sette tre landsdekkende aktører mot hverandre, er det neppe en overraskelse at vilkårene er ikke-diskriminerende. Sammenligner vi med Sverige, har man der kun to landsdekkende distributører (se kapittel 2).

At vilkårene ikke er diskriminerende betyr imidlertid ikke at priser og vilkår er identiske. Åpen tilgang til distribusjonssystemer vil ikke endre forskjeller i betingelser fra leverandør. Og, det er fortsatt slik at begrepet diskriminering vanskelig kan ramme forskjeller i vilkår som skyldes f.eks. kostnadsforskjeller og fordeler som følge av ulike mengder, sortimentsbredder og ulik geografisk spredning. Krav til ikke-diskriminering innebærer ikke nødvendigvis at de beste vilkår man har skal deles med den nye aktøren. Dersom hjemmelen for et slikt krav i tillegg skal finnes i konkurranselovens $₫ 11$, er terskelen svært høy for å innføre slike ordninger (se spesielt Hjelmengs diskusjon i kapittel 7). Alternativet er i så fall en egen regulering a la ekom-loven. I så fall må antagelig etableringshindringer som følger av at et mobilnettverk krever kanskje 6000 master fordelt over hele Norge kunne sammenlignes med tilgang til uavhengige lastebiler og lagerfasiliteter i utvalgte deler av Norge. En sammenligning som antyder at etablering av et fjerde distribusjonsnettverk av matvarer i Norge er langt enklere og billigere enn å bygge et nytt landsdekkende mobilnettverk.

Ikke-diskriminerende vilkår er heller ikke et presist begrep. Skal vi tro erfaringene fra teleregulering er det heller ikke like enkelt, hverken for dominerende aktør som selger tilgang eller for de som kjøper tilgang, å bli enige om hva ikke-diskriminerende vilkår innebærer. Årelange konflikter i og utenfor rettsalene mellom kjøpere og selgere, og ikke minst ansvarlig myndighet, viser at dette kan være en kostbar løsning for samfunnet. 
Så selv om reguleringen løser et mulig problem (tilgang til distribusjon), kan implementeringen og sikringen av regeloverholdelse bli kostnadskrevende og skape ekstra usikkerhet. Artiklene i denne boken tyder på at det ikke er et generelt effektivitetsproblem slike tiltak skal løse.

\section{Sterkere regulering og kontroll av dagligvarekjedenes eiendomstransaksjoner}

Dagligvarekjedene har i mer enn ti år gitt konkurransemyndighetene innsyn i sine kjøpskontrakter, og de må også informere om eiendomstransaksjoner. Dette skyldes at konkurransemyndighetene er redde for strategisk tilpasning i markedet for egnede butikklokasjoner. Kontroll med godt plasserte næringseiendommer og butikklokasjoner kan være avgjørende for evnen til å ta og forsvare markedsandeler lokalt. Det er naturlig å definere eierskap til butikklokaler som vertikal integrasjon mellom grossist eller detaljistkjede og en underleverandørsektor, og konkurranseloven pålegger myndighetene å påse at denne formen for vertikal integrasjon ikke har konkurransebegrensende effekt.

Mange kommentatorer har pekt på en tilsynelatende overetablering av butikker, noe som kan indikere at konkurransen om markedsandeler tas ut gjennom butikketablering heller enn konkurranse om pris og vareutvalg. Resultatene til Friberg mfl. i kapittel 2 tyder på at det kan være en overetablering av butikker i hovedstadsområdet (Oslo og Akershus). I så fall fører den strategiske utnyttelsen av butikklokasjoner til unødig høyt kostnadsnivå i dagligvarehandelen. I tillegg kan de reelle markedsandelene i kontrollen med eierskap av dagligvarebutikkene i seg selv avvike vesentlig fra strukturen i omsetningen av dagligvarer, med konsekvenser for mulighet for effektiv konkurranse om de beste lokalene.

Man finner også at sterk markedsmakt og manglende muligheter til å overføre butikklokaler mellom kjeder gir risiko for svekket produktivitetsvekst og ugunstig utvikling i marginene på distribusjonsleddene. All den tid konkurransemyndighetene allerede fortløpende oppdateres med informasjon rundt eiendomsdisponeringer, ligger forholdene til rette for mer aktiv kontroll når det kommer til denne delen av dagligvaremarkedet. Men igjen er dette et slags «både-og-problem». Reduseres muligheten til å etablere lokale butikker, reduseres faste kostnader i 
driften av Butikk-Norge. Dermed kan priser potensielt gå ned; men lokalt kan man gå glipp av økte konkurranseeffekter dersom man griper inn overfor etablering og kontroll med butikklokasjoner.

\section{Maksimalgrenser for markedsandeler}

Enkelte bidragsytere i debatten har vært inne på tanken om å innføre grenser for hvor store aktørene kan tillates å bli i dagligvaremarkedet, men dette er ikke uproblematisk. ${ }^{4}$ For det første er det ikke opplagt hvor en slik grense skal settes: i Finland har S-gruppen 46,4 prosent markedsandel, i Sverige har ICA 51,5 prosent. Hva skal norsk smerteterskel være? Men viktigere, hva vil da skje med insentivene til kjeden når denne nærmer seg markedsandelsgrensen? I en slik situasjon vil kjeden miste insentivene til videre organisk vekst, og dermed konkurrere mindre aggressivt. Samtidig kan man risikere at konkurransen svekkes i markedet. Faktum er at en slik ordning i verste fall kan gi en «markedsdelingsordning»noe som frivillig implementert ville vært ulovlig etter norsk konkurranselov. Igjen oppnår man noe med en slik regulering - redusert asymmetri i markedet, men prisen kan bli at de gunstige effektene av dette spises opp gjennom at den største kjeden «legger seg til hvile» rett under markedsandelsgrensen, og vi får redusert konkurranse.

\section{Effektivitet og rettferdighet}

Alle forslagene til regulering dreier seg om å sikre effektiv produksjon og distribusjon i verdikjeden for mat- og dagligvarer. Tiltak er også diskutert av Hjelmeng i kapittel 7. Spesielt gir Hjelmeng her også de konkurranserettslige rammene for de ulike alternativene. I sum, som vi diskuterer over, og i tråd med mye av Hjelmengs diskusjon, er det utfordrende å regulere seg vekk fra markedsproblemer som oppstår i et lukket matvaremarked i et langstrakt land med betydelige skalafordeler i distribusjon og foredling. At strukturen er ugunstig sett fra et konkurranseperspektiv, er 
udiskutabelt. Men det er ingen entydig sammenheng mellom struktur og konkurranse, og enda mindre mellom struktur og effektivitet.

Mye tyder samtidig på at strukturen og konkurransen vi har på distribusjonsleddene har gitt tilfredsstillende effektivitet, i hvert fall hvis vi sammenligner med effektivitet og produktivitetsutvikling i andre norske næringer (se mer i «produktivitetsanalysen» i kapittel 3). Det er betydelig risiko knyttet til sterke reguleringstiltak med usikker effekt. Så langt vi kan se er muligheten for effektivitetsgevinst begrenset, mens muligheten for effektivitetstap er stor. Reguleringer som ikke treffer reelle problemer, vil ha uønskede bivirkninger av usikker størrelsesordenen.

Derfor mener vi at hovedmålet med drøfting av mulige virkemidler bør være å sikre at utviklingen med god produktivitetsvekst fortsetter, og at den stimuleres der den i dag er svak. Blant mulige tiltak peker en viss, ganske forsiktig fjerning av unødig tollbeskyttelse seg ut som en opplagt kandidat for å håndtere kjernen i problemet: et for lukket matmarked. Skulle man ikke gjøre noe med hovedproblemet, gjenstår det konkurranseutfordringer i norsk matvaremarked, men skal man innføre tilleggsreguleringer ut over norsk konkurranselovgivning skal man tenke seg godt om. Da er det trolig en like attraktiv løsning å rette mer oppmerksomhet mot og ta i bruk de midlene myndighetene allerede har.

Artiklene i boken er ensidig opptatt av effektivitet, og vier så godt som ingen oppmerksomhet mot størrelsen på overskudd, formuen til dem som eier gårdsbruk, matindustri- eller dagligvareforetak. Det krever en forklaring.

Økonomisk og sosial bærekraft, effektivitet og rettferdighet, er i utgangspunktet like viktig. Fordelingen av verdier mellom bønder, industrieiere, arbeidere, eiere av grossist- og kjedeforetak, samt forbrukere er av stor betydning. Standarden for konkurransepolitikken er nettopp å sikre forbrukeren en størst mulig del av samlet verdiskaping, og unngå at nettopp forbrukerne påføres tap gjennom ineffektiv konkurranse.

Våre resultater og våre vurderinger av mulige tiltak for å sikre fortsatt produktivitetsvekst i matsektoren sier ikke noe om fordelingspolitikk, eller for den del rettferdighetshensyn. Men rettferdigheten blir ikke større om effektiviteten i dagligvarebransjen faller. Det er grunn til å vurdere om fordelingen av verdiskapingen er bærekraftig. Hvis svaret er nei, 
trenger vi fordelingspolitiske tiltak som i minst mulig grad reduserer den produktivitetsveksten vi så langt har nytt godt av. Det er vanskelig å se at rammebetingelser for en effektiv matsektor med god produktivitetsvekst er til hinder for god fordelingspolitikk.

Konkurransepolitikken er, ut fra diskusjonen i denne boken, egnet til å ivareta samfunnshensyn og forbrukerinteresser. En nyttig effekt av debatten om konkurranseutfordringene i det norske dagligvaremarkedet er at konkurransemyndighetene har fătt økte ressurser, og at oppmerksomheten rettet mot bransjen er styrket. Det er bra! Gjennom mer aktiv bruk av mulighetene som ligger i konkurranseloven, og en større synlighet av konkurransemyndighetene i bransjen, blir det vanskeligere for aktørene å lage avtaler som hindrer konkurransen å spille seg ut. En bieffekt kan også være at mulighetene for å styrke statistikk og vurderingsgrunnlaget, i tråd med anbefalinger i flere av artiklene i boken, kan få mer oppmerksomhet. 


\section{Referanser}

Alfnes, F. \& Dulsrud, A. (2016). Vareutvalg av mat og drikke i norske dagligvarebutikker: Utvikling, egne merkevarer og sammenligning med Sverige (SIFO rapport 7/2016). Hentet fra https://fil.forbrukerradet.no/wp-content/ uploads/2016/11/oppdragsrapport-nr-7-vareutvalg-av-mat-og-drikke-i-norskedagligvarebutikker.pdf

Alfnes, F., Schjøll, A. \& Dulsrud, A. (2019). Kartlegging av utviklingen $i$ butikkstruktur, dagligvareutvalg og dagligvarepriser (SIFO rapport 5/2019). Hentet fra https://www.regjeringen.no/globalassets/departementene/nfd/dokumenter/ rapporter/sifo-dagligvarerapport-korrigert-ver.pdf

ekomloven. (2003). Lov om elektronisk kommunikasjon (LOV-2003-07-04-83).

Hentet fra https://lovdata.no/dokument/NL/lov/2003-07-04-83

Foros, Ø. \& Kind, H. J. (2018a). Innkjøpspriser i dagligvaremarkedet. Samfunnsøkonomen, 132(4), 10-15.

Foros, Ø. \& Kind, H. J. (2018b). Asymmetriske innkjøpspriser $i$ dagligvaremarkedet. En vurdering av konsekvensene av et forbud mot prisdiskriminering fra dominerende leverandører (Rapport skrevet på oppdrag fra Rema 10oo). Hentet fra https://www.nhosh.no/contentassets/ b3e107a9593e4b9c9285ofbod9a318ao/8033315_1_foros-kind-asymmetriskeinnkjopspriser.pdf

Foros, Ø. \& Kind, H. J. (2019). Størrelsesbasert prisdiskriminering i det norske dagligvaremarkedet: teori og terreng. Samfunnsøkonomen 5/2019, 42-53.

Gabrielsen, T. S. \& Pettersen, I. (Red.) (2011). Dagligvarehandel og mat 2011. Perspektiver på verdikjeden for matvarer (NILF rapport). Hentet fra https://nibio.brage.unit.no/nibio-xmlui/bitstream/handle/11250/2463843/NILFDagligvarehandelogMat-2011.pdf? sequence $=2$ \&isAllowed $=\mathrm{y}$

Gabrielsen, T. S., Steen, F., Sørgard, L. \& Vagstad, S. (2013). Kjøpermakt i dagligvaresektoren (Rapport for Fornyings-, administrasjons- og kirkedepartementet). Hentet fra https://www.regjeringen.no/no/dokumenter/ kjopermakt-i-dagligvaresektoren/id723054/

Gabrielsen, T. S., Moen, E. R. \& Nilssen, T. (2020). Utredning om prisdiskriminering i dagligvarebransjen (Rapport for Nærings- og fiskeridepartementet). Hentet fra: https://www.regjeringen.no/contentassets/deac14c2eeef432487543fa5f7dedab5/ prisdiskriminering_170120.pdf

Gjendemsjø, R. \& Anchustegui, I. H. (2017). Høringsuttalelse - muligheten for å etablere en inngrepshjemmel mot ensidige handlinger $i$ verdikjeden for mat som ikke rammes av konkurranseloven $\$ 11$ (Utredning for Nærings- og 
fiskeridepartementet). Hentet fra https://www.regjeringen.no/contentassets/ eab200712f20412c997da6dee6ced5e6/utredning-av-inngrepshjemmel-motensidige-handlinger-1.pdf

Hjelmeng E. \& von der Fehr, N. H. (2018). Forbud mot prisdiskriminering - en overordnet og prinsipiell analyse (Rapport for NorgesGruppen). Hentet fra https://www.regjeringen.no/contentassets/4c26fo95eaaa4f9c9doo1762f78bcc72/ norgesgruppen-asa---vedlegg.pdf?uid=Norgesgruppen_ASA_-_vedlegg.pdf

Isaksen, T. R. (2018, april). Ncringsminister Torbjørn Røe Isaksens innlegg. Presentert ved åpningen av Dagligvarekonferansen 2018 i Oslo 9. april 2018. Hentet fra https://www.regjeringen.no/no/aktuelt/dagligvarekonferansen-2018/id2596586/

Konkurransetilsynet (2019). Kartlegging av innkjøpsbetingelser i norsk dagligvaresektor (2019). Hentet fra https://konkurransetilsynet.no/wp-content/ uploads/2019/11/Rapport-om-innkj\%C3\%B8psbetingelser_2019.pdf

Midttømme, K., Myklebust, A. Vikøren, S. \& Grimsby, G. (2019) Utredning av årsaker til ulike innkjøpspriser $i$ det norske dagligvaremarkedet (MENON rapport 103/2019). Hentet fra: https://www.menon.no/wp-content/uploads/2019-103\% 3 \% 85 rsaker-til-ulike-innkj\% $\mathrm{C}_{3} \%$ B8pspriser.pdf

Næringskomiteen. (2018). Innstilling fra noeringskomiteen om Representantforslag fra stortingsrepresentantene Terje Aasland, Ingvild Kjerkol og Anette Trettebergstuen om balansert makt $i$ verdikjeden for mat og dagligvarer (Innst. 292 S(20172018)). Hentet fra https://www.stortinget.no/globalassets/pdf/innstillinger/ stortinget/2017-2018/inns-201718-292s.pdf

Oslo Economics. (2019). Konsekvenser av et forbud mot prisdiskriminering i det norske dagligvaremarkedet (Rapport for NorgesGruppen). Hentet fra https://osloeconomics.no/wp-content/uploads/2019-36-Konsekvenser-av-etforbud-mot-prisdiskriminering.pdf

Oslo Economics \& Oeconomica. (2017). Etableringshindringer i dagligvaresektoren (Rapport for Nærings- og fiskeridepartementet 2017/46). Hentet fra https:/osloeconomics.no/wp-content/uploads/Etableringshindringer-idagligvaresektoren_ref2.pdf

Pettersen, I., Kjuus, J. \& Lavik, R. Stor prisforskjell - med naturlige, politiske og strukturelle forklaringer. I I. Pettersen \& T. S. Gabrielsen (Red.), Dagligvarehandel og mat 2011. Perspektiver på verdikjedene for matvarer (NILF Rapport, s. 67-86). Hentet fra http://hdl.handle.net/11250/2463843

Schumpeter, J. A. (2011). Capitalism, socialism and democracy (2. utg.). Eastford, CT: Martino Publishing. Originalverket utgitt 1947.

Skogli, E. \& Jenssen, T. B. (2016). Utvalget av mat og drikke i norsk og svensk dagligvare: En analyse av sammenlignbare butikker (MENON rapport 56/2016). Hentet fra https://www.menon.no/wp-content/uploads/2016-56-Utvalget-av-matog-drikke-i-svensk-og-norsk-dagligvare.pdf 


\title{
Annerledeslandet Norge: butikktilgjengelighet og markedskonsentrasjon i Sverige og Norge
}

\author{
Richard Friberg \\ Handelshögskolan i Stockholm
}

Ivar Pettersen

Norsk Institutt for bioøkonomi (NIBIO)

\section{Frode Steen}

Norges Handelshøyskole

\section{Simen A. Ulsaker}

Norges Handelshøyskole

\begin{abstract}
This chapter provides new numbers on retail concentration and grocery store availability in Norway. We compare Norway to the other Scandinavian countries and, in particular, to Sweden. Retail concentration is high, and highest in the countries with the highest distribution costs. As opposed to the neighboring countries, none of the internationally owned food chains are established in Norway. Decomposing concentration numbers on the county level in Sweden and Norway, we find concentration in Sweden to be highest in the most rural counties, with low population density. In Norway, we find highest concentration in some of the most central counties in the south of Norway, where population density is much higher than in the rest of the country. We also provide new numbers on the geographical distribution of grocery stores and grocery chains across Sweden and Norway. We find interesting new numbers on grocery store availability when comparing the two countries. Although Norway has more than twice as many grocery stores per inhabitant, the number of available stores within ten minutes' travelling time is surprisingly similar across the two countries. In fact, if we disregard the Norwegian capital area, the store
\end{abstract}

Sitering av denne artikkelen: Friberg, R., Pettersen, I., Steen, F. \& Ulsaker, S. A. (2020). Annerledeslandet Norge: butikktilgjengelighet og markedskonsentrasjon i Sverige og Norge. I F. Steen \& I. Pettersen (Red.), Mot bedre vitende i norsk matsektor (Kap. 2, s. 35-70). Oslo: Cappelen Damm Akademisk. https://doi.org/10.23865/noasp.93.ch2

Lisens: CC BY-ND 4.0. 
KAPITTEL 2

availability is even more equal across Swedish and Norwegian counties. Our results indicate that store density may be too high in the Norwegian capital area. This result is reinforced by the fact that Norwegian consumers in the capital area have access to Swedish border supermarkets with significantly lower prices and higher product variety within just 90 minutes' driving time.

Keywords: grocery retail, market shares, concentration indexes, HHI, store availability, store size distribution 


\section{Innledning}

Dagligvarebransjen har vært gjennom en kontinuerlig omstrukturering siden 1980-tallet, med færre, men større butikker, og langt høyere markedskonsentrasjon. ${ }^{1}$ I dag domineres de skandinaviske markedene av et fåtall integrerte paraplykjeder. Ifølge tall fra ACNielsen utgjorde uavhengige aktører 16,6 \% av norsk dagligvare i 1990; i 2018 var dette tallet 0,1\% (ACNielsen, 2000, slides 41, og 2019).

Noe av dette skyldes at forbrukere flytter til tettbygde strøk og behovet for mange små butikker dermed blir lavere. Dette er en internasjonal trend, men likevel har dagligvaremarkedet i Skandinavia endt opp med en større konsentrasjon enn det vi ser ellers i Europa (Nordic Competition Authorities, 2005). Et annet fenomen er at antall butikker per innbygger er høyere i Skandinavia enn i andre europeiske land som Tyskland, Belgia og Storbritannia (Jenssen \& Skogli, 2016).

I dette kapittelet vil vi se på noen av disse lange trendene, samt diskutere dagens situasjon i Norge mer inngående. Vi vil kontrastere den til situasjonen i Sverige, et nabomarked vi ofte sammenligner oss med.

Spesielt vil vi dekomponere butikk- og befolkningstetthet, samt markedsandeler og konsentrasjonsgrad regionalt på tvers av disse to landene. Basert på fullstendige butikkoversikter og detaljerte lokale tall på bosetning i Norge og Sverige beregner vi nye tall vi for butikk- og kjedekonsentrasjon, samt lokal butikktilgjengelighet.

I likhet med våre naboland har Norge høy konsentrasjon i detaljhandelen av dagligvarer. Vi skiller oss ikke ut på nivå, men vi har hatt en sterkere vekst i konsentrasjonen det siste tiåret. Den høyeste konsentrasjonen i Sverige er i mindre sentrale len med mindre befolkningstetthet. I Norge er konsentrasjonen høyest i de mer folkerike fylkene på Østlandet. NorgesGruppen dominerer sør for Trøndelag, mens Coop dominerer fra Trøndelag og nordover. Rema er relativt jevnt til stede i de ulike landsdelene. Vi finner også typisk internasjonale kjeder i andre nordiske land, men ikke i Norge.

Antall butikker har gått kraftig ned, men like fullt har Norge flere butikker i forhold til folketall enn det vi ser hos våre naboer.

1 For en detaljert beskrivelse av utviklingen i norsk dagligvaremarked se for eksempel Pettersen (2008). 
Gjennomsnittsbutikken i Norge er nesten $40 \%$ mindre enn gjennomsnittsbutikken i Sverge. Artikkelen beregner nye mål på butikktilgjengelighet, og viser at til tross for at Sverige har halvparten så mange dagligvarebutikker som Norge i forhold til befolkning, er landene overaskende like når det kommer til lokal butikktilgjengelighet. Mens innbyggeren i det mest typiske norske fylket har tilgang til 12 butikker innenfor 10 minutters reiseavstand, har innbyggeren fra det mest typiske, svenske lenet tilgang til 7 butikker. Landene blir enda mer like om vi ser bort fra hovedstadsområdene, da har gjennomsnittssvensken 9 butikker i nærheten, mens en norsk innbygger har 12. Sammenligner vi Nord-Sverige og Nord-Norge, er det mer enn dobbelt så mange butikker på norsk side (479) som på svensk side (204), men gjennomsnittsinnbyggeren på begge sider av grensen har tilgang til omtrent like mange butikker (6-7) innenfor 10 minutters reisetid.

Der Norge skiller seg kraftig ut er i hovedstadsregionen, hvor Norge har veldig stor butikktetthet, både om vi sammenligner med andre fylker og len, eller med hovedstadsområdet i Sverige. Innenfor 10 minutters reiseavstand har osloborgerne 137 butikker å velge mellom. Selv når vi ser på gjennomsnittsinnbyggeren i Oslo og Akershus samlet (som er mer sammenlignbart med Stockholm len), har gjennomsnittskonsumenten 80 butikker innenfor denne radiusen: En stockholmer har til forskjell bare 35 butikker å velge mellom. Med tanke på at bosettings- og urbaniseringsstrukturen neppe er så forskjellig mellom de to hovedstadsregionene, tyder dette på overetablering av dagligvarebutikker i den norske hovedstadsregionen. Tar vi hensyn til at de fleste kunder fra denne regionen bor mindre enn 90 minutter fra nærmeste svenske butikk med store vareutvalg og langt lavere priser, forsterkes konklusjonen om overetablering.

Sammenligner vi gjennomsnitt på tvers av fylker og len, øker landsnittene for begge land som følge av flere butikker i hovedstedene. Men der landsnittet i Sverige uten Stockholm går fra 10 til 9, går det i Norge fra 20 til 12 (samme som medianen).

Ser vi bort fra hovedstadsregionen viser butikktetthetsanalysen vår at det er nødvendig med mange flere butikker for å kunne gi nordmenn like god tilgjengelighet som svensker. Dette skyldes at vi har en helt annen topografi og bosettingsmønster koblet med et veinett som gjør at det 
simpelthen kreves flere butikker for å nå «hjem» til norske husholdninger. Dette burde også indikere at det blir mer effektivt med større og mer kostnadseffektive butikker i Sverige.

\section{Strukturendringer i butikktetthet og markedskonsentrasjon over tid}

\section{Butikk- og befolkningsutvikling}

I Norge fantes det i 1980 mer enn 8000 dagligvarebutikker, mens i 2018 var dette tallet mer enn halvert. Samtidig ble vi 1,2 millioner flere nordmenn i samme periode. I figur 1 viser vi befolkningsutvikling sammen med antall personer per butikk for disse fire tiårene. I 1980 fantes det 500 personer per butikk. I 2018 var dette tallet nesten tredoblet til nesten 1400 personer.

Sammenlignet med våre naboland er det imidlertid enda et stykke igjen. I Sverige har gjennomsnittsbutikken i 2018 mer enn dobbelt så mange svensker, mens man i Danmark synes å være noe gladere i nærbutikkene sine, og er midt mellom Norge og Sverige med i overkant av 1900 dansker per butikk (2015). Sammenlignet med land som Storbritannia og Belgia, har imidlertid alle tre landene langt færre personer per butikk (Nordic Competition Authorities, 2005).

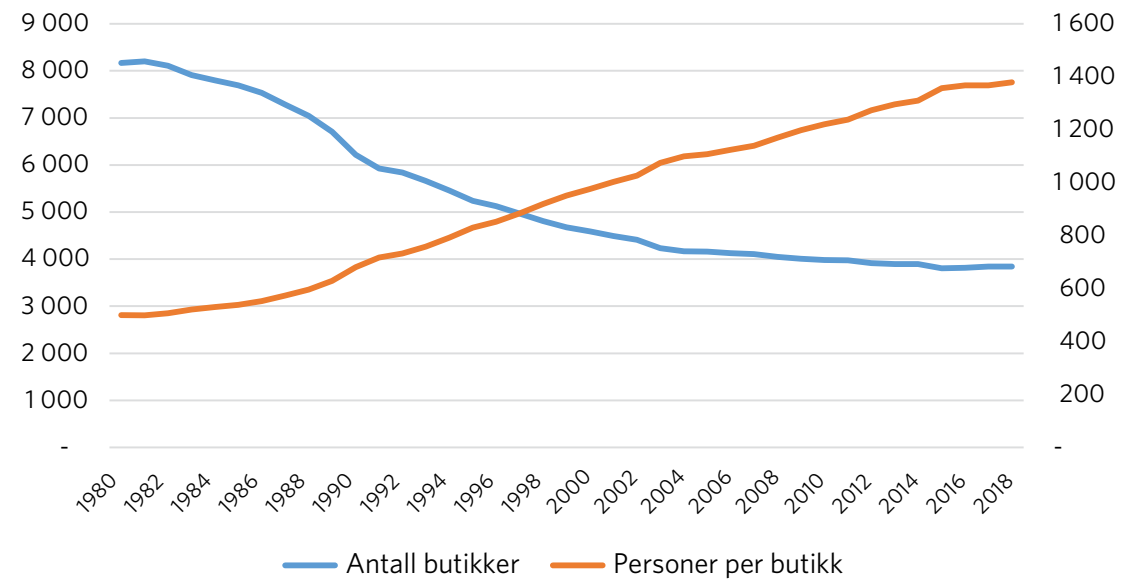

Figur 1 Utviklingen i antall butikker (venstre akse) og antall personer per dagligvarebutikk (høyre akse) i perioden 1980-2018. Kilder: ACNielsen og SSB. 
Forklaringene er flere og ikke minst knyttet til endringer i demografi og bosettingsmønster. Å betjene kunder i Skandinavia, der kundene er færre og mer spredtboende enn på store deler av kontinentet, krever en helt annen butikkstruktur. Vi vil senere se nærmere på dette når vi dekomponerer tallene regionalt.

\section{Utvikling i markedsandeler og konsentrasjon}

En annen endring, som man har blitt mer og mer opptatt av, er utviklingen i konsentrasjon. Markedene har gjennom fusjoner, oppkjøp, restrukturering og utstrakt «kjedifisering» blitt mye mer konsentrert over tid. Denne endringen reiser spørsmål om konkurranse- og forbrukerpolitikk siden høy konsentrasjon kan være forbundet med markedsmakt og lite konkurranse (se f.eks. Sexton, 2013).

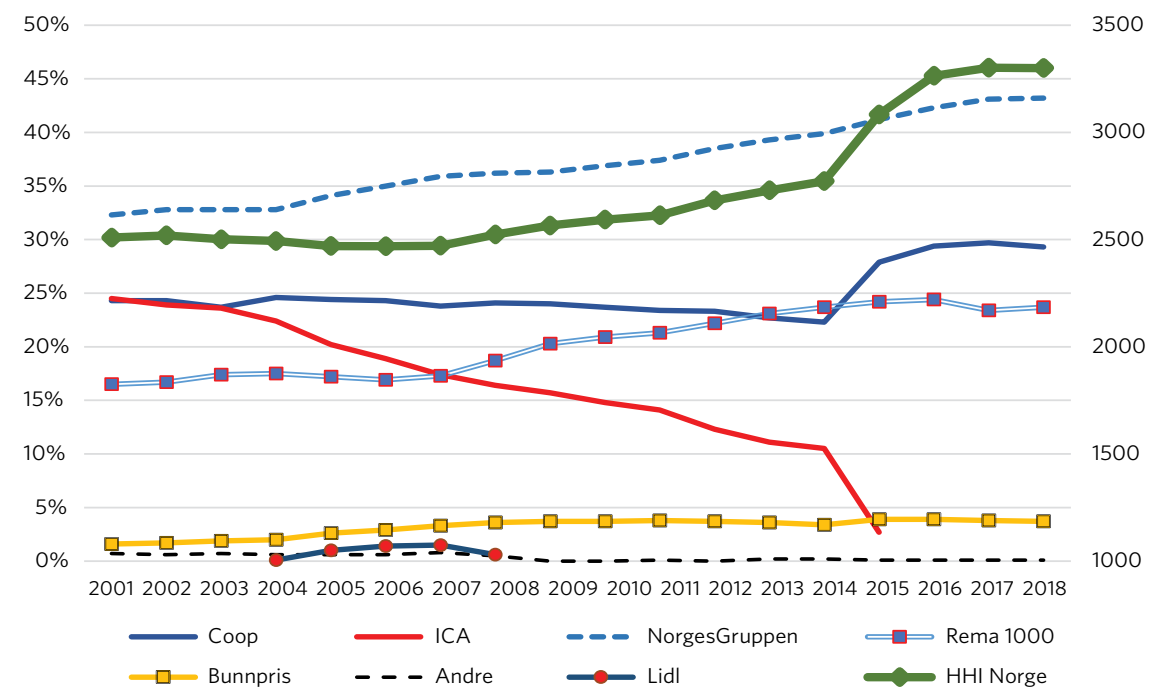

Figur 2 Utvikling i markedsandeler (venstre akse) og Herfindahls-indeksen (høyre akse) i det norske dagligvaremarkedet 1994-2018. Kilde: ACNielsen-rapporter.

I figur 2 ser vi utviklingen i markedsandeler tilbake til 2001. ${ }^{2}$ Utviklingen går klart i retning av færre og større aktører. ICA er ute av markedet, og Lidl var bare inne i fem år. I 2001 delte fire aktører markedet, der tre av

2 Merk at ACNielsen endret sin måte å beregne omsetning/markedsandeler på slik at kun tall 40 tilbake til 2001 er sammenlignbare over tid (ACNielsen, Dagligvarerapporten 2002). 
dem lå mellom 24 og $32 \%$, mens Rema 1000 som utfordrer hadde $17 \%$ av markedet. Uavhengige aktører utgjorde 2,3 \% av markedet. I 2018 har vi kun tre større aktører igjen, og NorgesGruppen har mer enn $40 \%$ av markedet alene. Tidsdynamikken preges mye av ICAs fall i markedsandel fra 25 til $11 \%$ over 18 -årsperioden, som kulminerte med Coops oppkjøp i 2014. Rema 1000 har den klart største veksten av de store aktørene over perioden: markedsandelen går fra 17 til $24 \%$, en relativ vekst på $44 \%$. NorgesGruppen vokser med 11 prosentpoeng, fra 32 til $43 \%$, noe som innebærer en relativ vekst på 34 \% over perioden, mens Coop vokser med 5 prosentpoeng fra 24 til $29 \%$ - en relativ vekst på $21 \%$. Selv om Bunnpris vokser fra et lavt utgangspunkt på 1,6 \% i 2001, mer enn dobler de andelen sin over perioden med en relativ vekst på $131 \%{ }^{3}$

Den vanligste måten å måle konsentrasjon er gjennom den såkalte Herfindahl-Hirschman indeksen (HHI), som er summen av aktørenes kvadrerte markedsandeler. ${ }^{4}$ Det er mye fokus på at oligopoler med tilstrekkelig høy HHI er bekymringsverdige. Konkurransemyndighetene har for eksempel kjøreregler for fusjonskontroll, der høyere nivåer på HHI typisk gjør ytterligere fusjoner vanskelige i et marked. ${ }^{5}$ Selv om konsentrasjon opplagt ikke er et entydig mål på konkurransepresset i et marked, har konsentrasjonsmåling blitt en av flere mulige indikatorer på konkurranse. ${ }^{6}$

3 Bunnpris har gjennom tiden kjøpt distribusjon gjennom Rema 1000 og NorgesGruppen. I så måte er de mindre uavhengig enn de tre store aktørene, eller hvordan ICA var da de var i det norske markedet.

4 Herfindahl-Hirschman-indeksen (HHI) gir et mål på markedskonsentrasjon og asymmetri i markedsandeler, hvor begge deler er funnet å kunne påvirke konkurransepresset i et marked. Rent teknisk beregnes den med å summere de kvadrerte markedsandelene: $H H I=\sum_{i=1}^{n} s_{i}^{2}$, hvor $i$ refererer til bedrift/firma og $s$ til markedsandel. Som det fremgår av formelen innebærer dette at HHI finner sitt maksimum for et monopol der $s=100$ og HHI=10 ooo. Herfindahl-Hirschman-indeksen har flere gode egenskaper siden den både tar hensyn til konsentrasjon og asymmetri i konsentrasjon. Både høy konsentrasjon og høy asymmetri kan lede til redusert konkurransepress i et marked.

5 EU har formulert terskelverdier for HHI, der de sier at det er usannsynlig at de griper inn mot en fusjon så lenge som HHI er under 1000 etter fusjonen, mens en HHI mellom 2000 og 3000 etter en eventuell fusjon gir grunnlag for bekymring i den forstand at endringen i HHI som følge av fusjonen bør være under 250. I markeder med HHI over 3000 er kravet enda strengere, da vil selv endringer over 150 være bekymringsfullt. Oppsummert betyr det at markeder med HHI over 2000 typisk gir grunn til bekymring rundt konkurransen i markedet.

6 Eksempler på forhold som kan tale for at markeder er mindre problematiske er store og velinformerte profesjonelle kjøpere (kjøpermakt) og lave etableringsbarrierer. 
I figur 3 har vi også beregnet HHI over perioden 2005 til 2018. Som et resultat av endringene i sammensetning og antall aktører stiger denne over perioden. Allerede i 2001 var den på 2509, et nivå som er over første kritiske EU-terskel. Trenden de første 10 årene er ganske flat, og i 2011 har vi fremdeles et konsentrasjonsnivå på nesten samme nivå (HHI i 2011=2613), men de neste syv årene øker den med 26 \%. I 2018 er HHI oppe i 330o, og overstiger EUs høyeste terskelverdi. Alene basert på konsentrasjon, indikerer dette at konkurransen mellom kjedene har falt over perioden.

Sammenligner vi med utviklingen i våre naboland - Sverige, Danmark og Finland - skiller ikke Norge seg mye ut med hensyn til nivå på konsentrasjonen, men vi skiller oss ut når det kommer til trend. I figur 4 viser vi utviklingen i HHI for de fire landene tilbake til 2005.

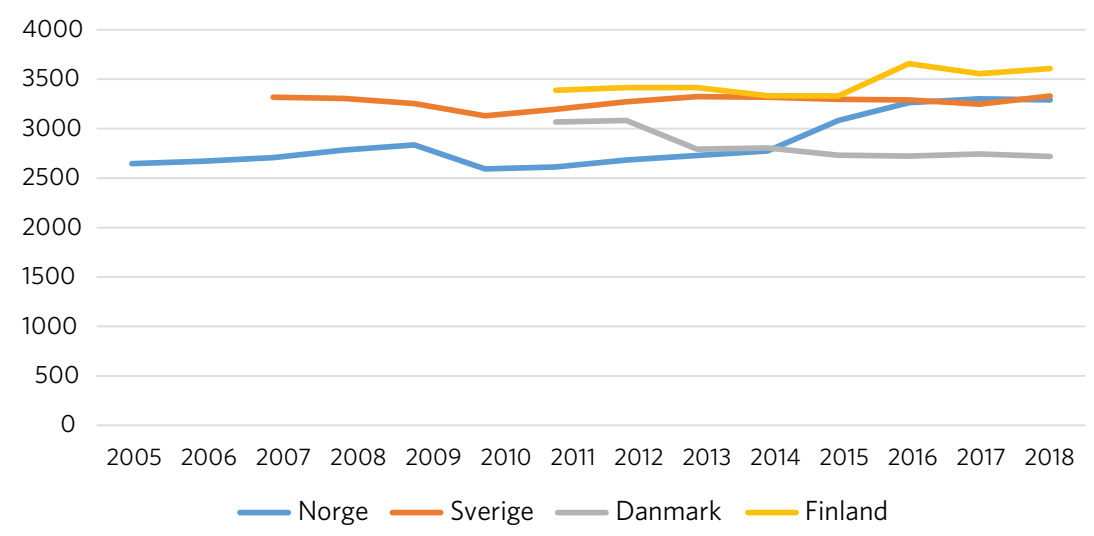

Figur 3 Utvikling i Herfindahl-Hirschman-indeksen i det norske, danske og svenske dagligvaremarkedet 2005-2018. Kilde: ACNielsen-rapporter.

Sverige har en flat utvikling, der HHI i perioden 2007-2018 ikke beveger seg vekk fra rundt 3300. Danmark starter fra en HHI over 3000 i 2011, men beveger seg nedover med $11 \%$ over perioden og har lavest HHI av alle fire i $2018(\mathrm{HHI}=2719)$. Finland har som Norge hatt en økning i konsentrasjonen over perioden. Finland hadde allerede i 2011 det høyeste konsentrasjonsnivået, men da ikke så langt over Sverige og Danmark. I 2018 hadde HHI økt til hele 3609. Norge starter ut fra det laveste nivå av de fire landene, men her vokser konsentrasjonen over hele perioden. 
HHI øker med 26 \% fra 2011 til 2018, og ender opp på 330o, noe som er på nivå med Sverige. I sum er alle de fire nordiske markedene svært konsentrert, og med unntak av Danmark er HHI over EUs øverste «bekymringsterskel» på $\mathrm{HHI}=3000$. Norge skiller seg lite ut på nivå i 2018, men har til gjengjeld gått fra å ha klart lavest konsentrasjon til å bli par med Sverige og Finland.

Strukturen i de fire landene er imidlertid forskjellig. Vi illustrerer markedsandeler i figur 4. I Danmark og Sverige har man, i tillegg til de tre store og dominerende aktørene, tre mindre aktører som deler mellom 14 og $17 \%$ av markedet. Selv om ICA i Sverige har halvparten av markedet er dermed konsentrasjonen likevel på nivå med i Norge. Finland og Norge mangler denne halen, men mens det i Norge er et triopol som deler $96 \%$ av markedet, er deltakerne langt mer jevnstore enn i Finland, der to aktører har mer enn fire femtedeler av markedet.

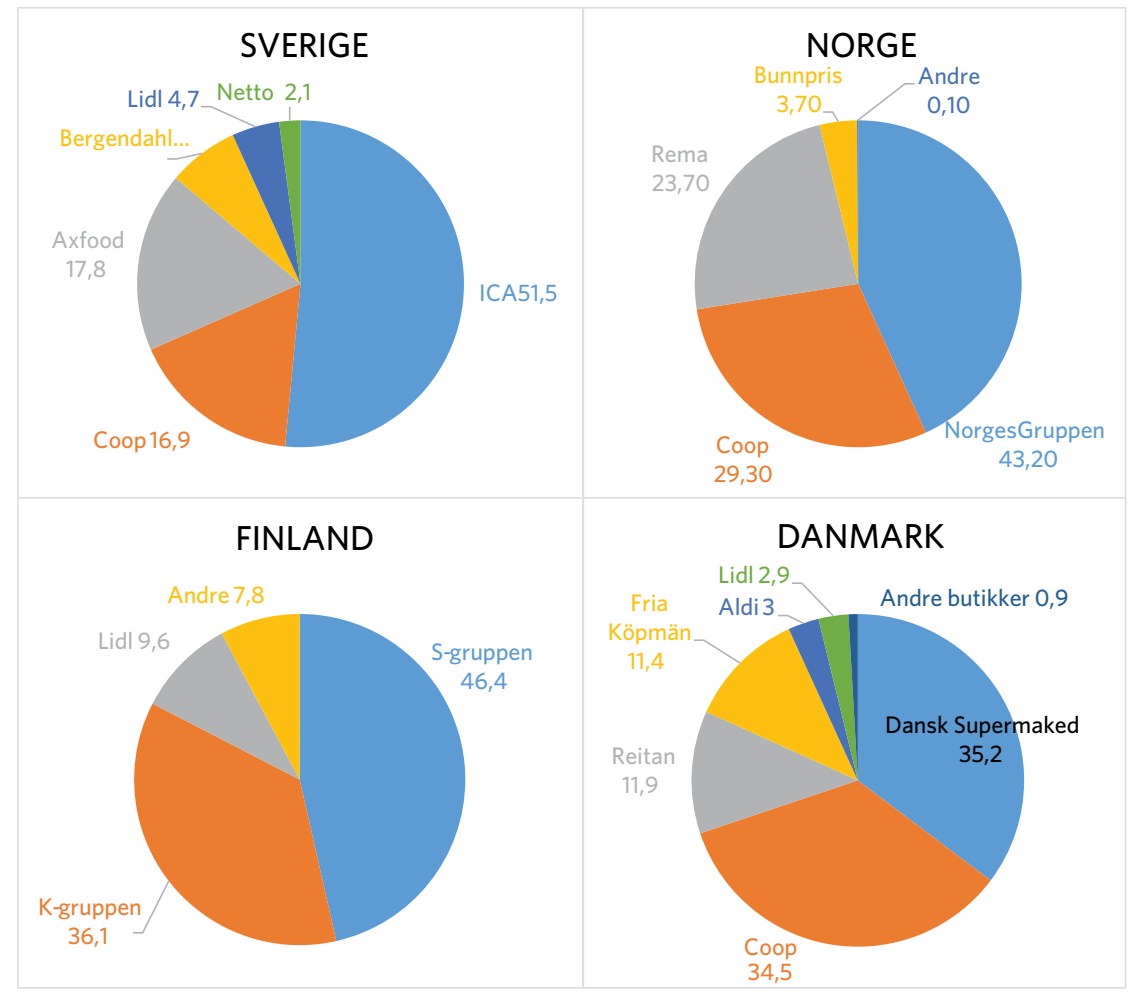

Figur 4 Markedsandeler 2018 for Norge, Sverige, Danmark og Finland. Kilde: Svensk Dagligvarukartan og Delfi, 2019. 
Forskjellene i 2018 som vi ser fra figur 4, er også rimelig stabile over tid. I tabell 1 ser vi på markedsandelene for de største aktørene over de siste 8 årene.

Tabell 1 Gjennomsnittlig konsentrasjonsgrad i prosent i Sverige, Danmark, Finland og Norge 2011-2018. Kilde: Dagligvarukartan, Delfi og ACNielsen.

\begin{tabular}{|l|r|r|r|r|}
\hline & Sverige & Danmark & Finland & Norge \\
\hline Største aktør & 50,5 & 36,9 & 45,9 & 40,6 \\
\hline To største aktører & 70,3 & 69,7 & 80,7 & 66,6 \\
\hline Tre største aktører & 86,5 & 86,3 & 88,1 & 89,9 \\
\hline
\end{tabular}

Den største aktøren har mellom 37 og 51 \% over åtteårsperioden.? Ser vi på de to største varierer tallet mellom 67 og $81 \%$, der Finland skiller seg kraftig ut med et sterkt duopol. De tre andre landene er tilforlatelig like, der de to største aktørene deler mellom 67 og $70 \%$ av sine nasjonale marked. Sammenligner vi land, ser vi at tre aktører typisk dominerer markedene i alle land, der de har markedsandeler på til sammen 86-90 \% over perioden. ${ }^{8}$

Siden de største aktørene er så vidt mye større enn de andre, er det $\mathrm{i}$ utgangspunktet liten grunn til å tro at de stores forhandlingsstyrke eller kjøpermakt er veldig forskjellig på tvers av land. I så måte skulle man vente at de mindre kjedene har like store etableringsbarrierer i de fire landene. Det er opplagt flere mulige forskjeller i etableringshindringer mellom disse landene, men en viktig forskjell er at i våre naboland er det større mulighet for de mindre kjedene å hente innkjøp utenfor de nasjonale markedene, da importvernet innenfor EU er lavere enn mellom Norge og EU. Kjeder som Lidl og Aldi kan dermed i større grad dra nytte av sin internasjonale størrelse og sine internasjonale distribusjonsnettverk. Selv i Finland, der de to store fullstendig dominerer, har Lidl doblet sin tilstedeværelse fra 2011 til 2018, og vokst fra 5 til $10 \%$ av markedet. I Sverige har Lidl (om enn fra et lavt nivå) økt sin andel med

7 ICA skiller seg litt fra de andre. De har relativt desentralisert drift og eierskap på butikknivå, og de har ikke nasjonal prising i Sverige. De har imidlertid felles distribusjon og innkjøp.

8 Siden ICA forlot markedet i Norge, har vi fått økt konsentrasjon, noe som opplagt påvirker tallene. Snittet for siste tre år i Norge er 42,7 \%, 72,4\% og 96,2 \% for henholdsvis største, to største og tre største aktører. Dette innebærer at Norge blir likere Finland over tid. 
47 \% over samme periode, og også i Danmark har Aldi og Lidl økt sin tilstedeværelse over perioden. Lokal tilstedeværelse av disse internasjonale kjedene endrer også markedet i andre dimensjoner. Gjennom import av produkter som vi typisk ikke finner hos de store nasjonale aktørene, og andre driftskonsept (eksempelvis mer gjennomførte «hard core discount»-konsepter) differensieres markedet. Større grad av produktdifferensiering og muligheten for aktører som Aldi og Lidl til å «importere» sin forhandlingsstyrke påvirker dermed forhandlingsspillet mellom kjeder og leverandører, og begrenser trolig muligheten for større nasjonale leverandører å kunne prisdiskriminere mellom kjeder, slik vi nylig har sett tall for i Norge (Konkurransetilsynet, 2019). Over tid kan dermed etableringsmulighetene for internasjonale dagligvareaktører med egne leverandørrelasjoner innebære større muligheter for mer intensiv kamp om markedsandeler og strukturendring over tid.

Endelig er de fire markedene svært forskjellige når det kommer til distribusjonskostnader. Norge, Sverige og Finland er alle mellom 8 og 10 ganger større i geografisk utstrekning enn Danmark, og i så måte er det større faste distribusjonskostnader i disse landene. ${ }^{9}$ Dette betyr at spesielt i mindre urbane områder vil oppbygging av nasjonalt dekkende butikktilbud være mer kostbart. Noe som nok forklarer hvorfor en aktør som Bunnpris ikke har valgt å bygge opp sin egen distribusjon i Norge, men kjøper dette av de store kjedene. I neste seksjon ser vi nærmere på konsentrasjons- og butikktall lokalt for Norge og Sverige.

9 Danmark har et flateinnhold på $43049 \mathrm{~km}^{2}$, mens Norge $\left(385207 \mathrm{~km}^{2}\right)$, Sverige $\left(449964 \mathrm{~km}^{2}\right) \mathrm{og}$ Finland $\left(338424 \mathrm{~km}^{2}\right)$ har langt større utstrekning. Vel har Sverige langt flere innbyggere, men her er Danmark, Finland og Norge svært like (mellom 5,3 og 5,6 millioner). 


\section{En sammenligning av butikktetthet og markedskonsentrasjon i Norge og Sverige}

Her benytter vi detaljerte butikkdata fra Delfi i Sverige og Geodata i Norge for å analysere både markedskonsentrasjon og butikkfordeling på tvers av norske fylker og svenske len. Vi har også estimert hvor mange butikker man har tilgjengelig lokalt innenfor 10 minutters reisetid. ${ }^{10}$

Butikkdataene gir oss nøyaktig beliggenhet og omsetning for alle butikker i begge land. I tillegg har vi detaljerte og svært disaggregerte data for hvor folk bor. For Norge benytter vi data på grunnkretsnivå, som er det mest detaljerte nivået for offentlig befolkningsstatistikk. Det tilsvarende nivået i Sverige er DeSo (Demografiska Statistikområden). Vi har dermed kunnet beregne reiseavstand fra senter av grunnkrets eller DeSo til nærmeste butikker, og aggregert disse tallene til fylkes- og lensnivå. ${ }^{11}$ Dette gir oss et svært detaljert bilde av markedsandeler og butikktilgjengelighet. Tidligere studier av butikktilgjengelighet har kun sett på butikker per fylke/len eller region. I så måte gir våre tall et mye bedre bilde av lokal butikktilgjengelighet enn det for eksempel fylkes-/lenstall for innbyggere per butikk kan gi oss. Gitt at alle norske tall er fra 2018, baserer analysen seg på fylkesfordelingen som gjaldt frem til 01.012020 for Norge. Opplagt vil antall butikker innenfor 10 minutters reiseavstand være korrelert med antall personer per butikk i en region, men det første tallet gir en mye mer presis beskrivelse av faktisk butikktilgjengelighet.

I tabellene 2 og 3 viser vi en regional oversikt over ulike variabler for Norge og Sverige for $2018 .^{12}$

10 Avstand er beregnet som 10 minutters reisetid med bil. Opplagt kan man velge andre definisjoner av nærhet. I et tett befolket område vil for eksempel 5 minutters reisetid kanskje være like relevant. Vi har valgt å benytte 10 minutter og en standardisert målemetode for å kunne sammenligne butikktilgjengelighet på tvers av regioner og land.

11 Tall på fylkesnivå (lensnivå) er et vektet snitt av tallene på grunnkretsnivå (DeSo-nivå), der hver grunnkrets (DeSo) vektes med befolkningsandelen. Den forenklende antagelsen vi gjør i denne analysen er at alle bor i midtpunktet av sin grunnkrets (DeSo).

12 For Norge er alle tall fra 2018, mens for Sverige er butikkdata fra 2018 og befolkningsdata fra 2016. 
Tabell 2 Fylkesvis fordeling av befolkning, butikker, nærhets- og konsentrasjonsgrad i Norge.

\begin{tabular}{|c|c|c|c|c|c|}
\hline Fylke & Befolkning & $\begin{array}{r}\text { Antall } \\
\text { butikker }\end{array}$ & $\begin{array}{r}\text { Personer } \\
\text { per } \\
\text { butikk }\end{array}$ & $\begin{array}{r}\text { Antall } \\
\text { butikker } \\
\text { innenfor } \\
10 \text { min } \\
\text { reiseavstand }\end{array}$ & $\begin{array}{r}\text { HHI } \\
\text { fylke }\end{array}$ \\
\hline Oslo & 673469 & 355 & 1897 & 137 & 3636 \\
\hline Akershus & 614026 & 296 & 2074 & 18 & 3713 \\
\hline Hordaland & 522539 & 378 & 1382 & 21 & 3282 \\
\hline Rogaland & 473526 & 302 & 1568 & 24 & 3376 \\
\hline Trøndelag & 458744 & 358 & 1281 & 21 & 3475 \\
\hline Østfold & 295420 & 164 & 1801 & 15 & 3397 \\
\hline Buskerud & 281769 & 178 & 1583 & 12 & 4937 \\
\hline Møre og Romsdal & 266856 & 266 & 1003 & 7 & 2893 \\
\hline Vestfold & 249058 & 142 & 1754 & 12 & 4694 \\
\hline Nordland & 243335 & 252 & 966 & 8 & 3208 \\
\hline Hedmark & 196966 & 169 & 1165 & 8 & 3985 \\
\hline Oppland & 189870 & 172 & 1104 & 5 & 3730 \\
\hline Vest-Agder & 186532 & 140 & 1332 & 12 & 3454 \\
\hline Telemark & 173391 & 144 & 1204 & 14 & 4741 \\
\hline Troms & 166499 & 142 & 1173 & 9 & 3738 \\
\hline Aust-Agder & 117222 & 102 & 1149 & 9 & 3573 \\
\hline Sogn og Fjordane & 110230 & 146 & 755 & 3 & 2988 \\
\hline Finnmark & 76167 & 85 & 896 & 4 & 3271 \\
\hline Norge (snitt) & 294201 & 211 & 1338 & 19 & 3672 \\
\hline Norge (median) & 246197 & 171 & 1243 & 12 & 3524 \\
\hline Norge totalt & 5295619 & 3791 & 1397 & & 3293 \\
\hline
\end{tabular}


Tabell 3 Lensvis fordeling av befolkning, butikker, nærhets- og konsentrasjonsgrad i Sverige.

\begin{tabular}{|c|c|c|c|c|c|}
\hline Len & Befolkning & $\begin{array}{r}\text { Antall } \\
\text { butikker }\end{array}$ & $\begin{array}{r}\text { Personer } \\
\text { per } \\
\text { butikk }\end{array}$ & $\begin{array}{r}\text { Antall } \\
\text { butikker } \\
\text { innenfor } \\
10 \mathrm{~min} \\
\text { reiseavstand }\end{array}$ & HHI fylke \\
\hline Stockholm & 2263172 & 561 & 4034 & 35 & 2817 \\
\hline Västra Götaland & 1669011 & 486 & 3434 & 16 & 3085 \\
\hline Skåne & 1321644 & 374 & 3534 & 20 & 2984 \\
\hline Östergötland & 451548 & 131 & 3447 & 12 & 2925 \\
\hline Uppsala & 360892 & 97 & 3721 & 13 & 3570 \\
\hline Jönköping & 352433 & 119 & 2962 & 7 & 2988 \\
\hline Halland & 320019 & 88 & 3637 & 6 & 3500 \\
\hline Örebro & 294547 & 96 & 3068 & 13 & 3396 \\
\hline Södermanland & 287711 & 97 & 2966 & 9 & 2858 \\
\hline Gävleborg & 284275 & 107 & 2657 & 8 & 3446 \\
\hline Dalarna & 284218 & 126 & 2256 & 5 & 3244 \\
\hline Värmland & 279057 & 132 & 2114 & 7 & 2894 \\
\hline Västmanland & 267195 & 77 & 3470 & 14 & 3453 \\
\hline Västerbotten & 265679 & 107 & 2483 & 8 & 4472 \\
\hline Norrbotten & 250386 & 97 & 2581 & 5 & 4086 \\
\hline Västernorrland & 245308 & 91 & 2696 & 6 & 3537 \\
\hline Kalmar & 242060 & 105 & 2305 & 5 & 3789 \\
\hline Kronoberg & 194435 & 71 & 2739 & 7 & 3305 \\
\hline Blekinge & 158302 & 50 & 3166 & 5 & 2804 \\
\hline Jämtland & 128584 & 74 & 1738 & 4 & 5034 \\
\hline Gotland & 57946 & 29 & 1998 & 5 & 4325 \\
\hline Sverige (snitt) & 475163 & 148 & 2905 & 10 & 3453 \\
\hline Sverige (median) & 284218 & 97 & 2962 & 7 & 3396 \\
\hline Sverige totalt & 9978422 & 3115 & 3203 & & 3066 \\
\hline
\end{tabular}




\section{Butikktetthet}

La oss først se på befolkning og antall butikker. Disse størrelsene er opplagt korrelert med hverandre - fylker med stor befolkning har mange butikker. Dette er illustrert i figur 5 , hvor vi også ser at antall butikker følger befolkningsstørrelsen mye tettere i Sverige enn i Norge. Interessant nok er korrelasjonen bortimot en for Sverige $(0,991)$, mens den er svakere for Norge $(0,891)$. Dette skyldes trolig at bosetningsmønsteret er forskjellig på tvers av landene, typisk bor for eksempel svenskene mer konsentrert rundt tettsteder enn nordmenn som har en mer fragmentert bosetting.

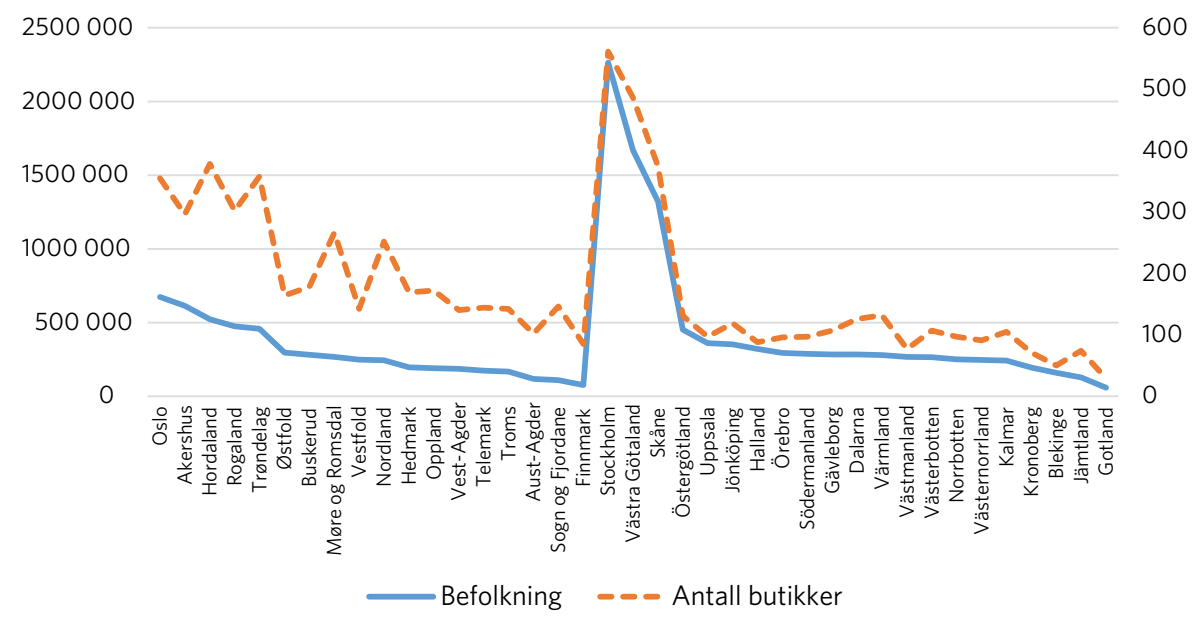

Figur 5 Befolkning og antall butikker på tvers av fylker og len i Norge og Sverige.

La oss nå fokusere på antall personer per butikk, som så langt har vært det vanligste målet på butikktilgjengelighet. ${ }^{13} \mathrm{Vi}$ observerer at antall personer per butikk er mye lavere i medianfylket i Norge (1243) enn i medianlenet i Sverige (2962), noe som avspeiler at det er flere butikker i Norge til tross for at det går nesten to svensker på hver nordmann. Det er imidlertid mye variasjon på tvers av fylker og len i begge land: I Sogn og Fjordane er det bare 755 innbyggere per butikk, noe som er 36 \% av nivået i Akershus (2074 innbyggere per butikk).

13 Ofte ser man det inverse tallet presentert: Tall for antall butikker per 10 ooo innbygger. Begge tall gir samme informasjon. 
Ser vi på tilsvarende for Sverige utgjør lenet med færrest innbyggere per butikk, Jämtland (1738), 43 \% av lenet med flest, Stockholm, som har 4034 innbyggere per butikk. Det betyr at begge land har en lignede stor spredning mellom fylker/len.

Vårt nye mål for butikktilgjengelighet viser mindre forskjeller mellom landene. Ser vi på antall butikker innenfor 10 minutters reiseavstand, er dette mye mer likt på tvers av land. Innbyggeren som lever i medianfylket i Norge har 12 butikker innenfor 10 minutters avstand, mens en svensk innbygger i medianlenet har 7 butikker innenfor 10 minutters reiseavstand. Størst avvik ser vi for Stockholm og Oslo, som har flere butikker tilgjengelig. Men her skiller Norge seg tydelig ut fra Sverige. Stockholm har 35 butikker innenfor 10 minutters reiseavstand, mens Oslo har utrolige 137 butikker innenfor 10 minutters reiseavstand. Sammenligner vi gjennomsnitt på tvers av fylker og len, øker landsnittene for begge land som følge av flere butikker i hovedstadsområdene, men mens landsnittet $\mathrm{i}$ Sverige uten Stockholm går fra 10 til 9, går det i Norge fra 20 til 12 (samme som medianen).

Siden størrelsen på Stockholm og Oslo er veldig forskjellig - Oslo er mye mindre i utstrekning, bare $454 \mathrm{~km}^{2}$, mens Stockholm strekker seg over $6488 \mathrm{~km}^{2}$ - er sammenligningen over ikke uproblematisk. Tar vi imidlertid med Akershus fylke, som ligger rundt Oslo og utgjør 4917 $\mathrm{km}^{2}$, blir områdene mer sammenlignbare. I Oslo og Akershus bor 1,3 millioner innbyggere, dvs. $24 \%$ av Norges befolkning. Tilsvarende bor det 2,3 millioner mennesker i Stockholms len, eller $23 \%$ av alle svensker. Landområdene utgjør begge $1,4 \%$ av sine respektive lands arealer.

Hvis vi nå regner ut butikktilgjengelighet innenfor 10 minutters reiseavstand i Oslo og Akershus, er dette fremdeles et veldig høyt tall. Innbyggerne i disse to fylkene har i gjennomsnitt (sett som én region, vektet med antall innbyggere) 80 butikker innenfor 10 minutters reiseavstand. Med tanke på at befolkningstettheten i Stockholms len er mye større - det bor 349 svensker per $\mathrm{km}^{2} \mathrm{i}$ denne regionen, til sammenligning bor det i Oslo og Akershus bare 240 innbyggere per $\mathrm{km}^{2}$ - betyr dette at butikktettheten i den norske hovedstadsregionen er veldig høy.

Noe som ytterligere peker i retning av en slik konklusjon, er det norske hovedstadsområdet nærhet til svenske grensesupermarked. 
Konsumentene i Oslo og Akershus har i hovedsak mindre enn 90 minutters reisetid til nærmeste svenske grensebutikk (Friberg, Steen \& Ulsaker, 2019). Svenske dagligvarepriser er, som vist kapittel 4 i denne boken av Pettersen (2020), vesentlig lavere enn de norske, og grensehandelen fra Norge er stor. Dette betyr at beboerne i det norske hovedstadsområdet har et signifikant tilbud også fra svenske butikker. Om noe skulle man tro at dette reduserte behovet for stor butikktetthet lokalt.

Oppsummerer vi sammenligningen i butikktilgjengelighet/-nærhet mellom disse to landene, så er Sverige og Norge overraskende like når det kommer til tilgjengelighet av butikker når vi ser bort fra hovedstadsområdene. Mens mye taler for at i hovedstadsregionen i Norge har en butikktetthet som langt overstiger det vi ser i Sverige i tilsvarende områder.

Dette ser vi svært godt også i figur 6, der vi viser disse størrelsene for begge land. Mens personer per butikk er mye mer forskjellig på tvers av land er landsforskjellene mye mindre når det kommer til butikker innenfor 10 minutters reiseavstand, med unntak av Oslo (eventuelt Oslo/ Akershus) som er langt utenfor skalaen.

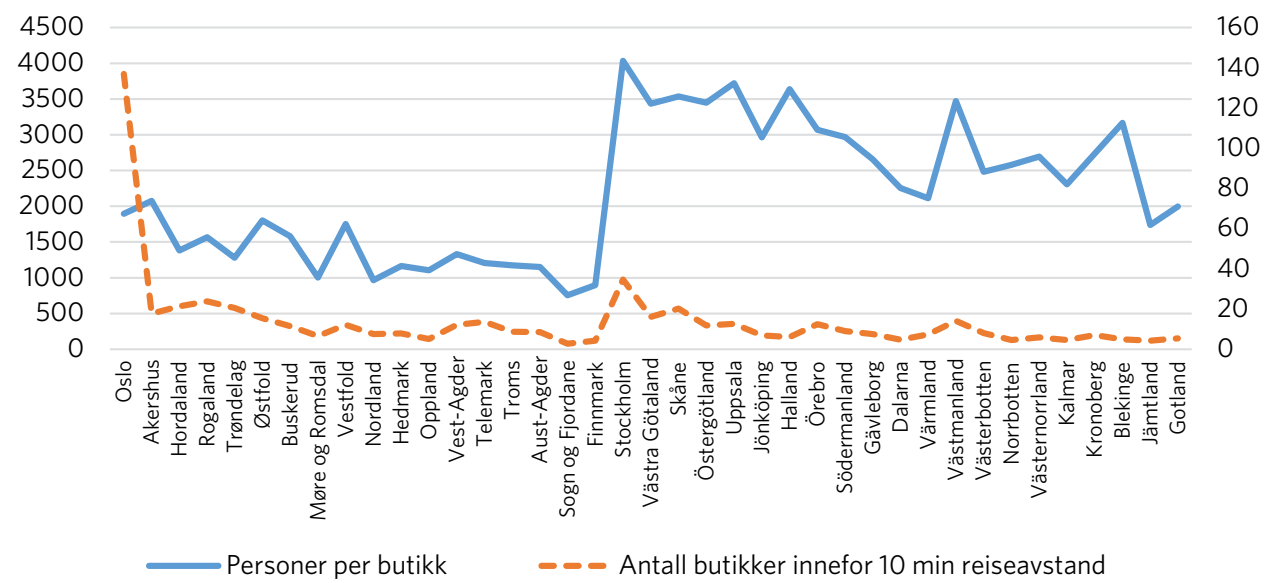

Figur 6 Personer per butikk (venstre akse) og antall butikker innenfor 10 minutters reiseavstand (høyre akse) på tvers av fylker og len i Norge og Sverige. 
Det er heller ikke noen åpenbar sammenheng mellom de to butikktilgjengelighets-/nærhetsmålene. Korrelasjonen mellom dem er for Sverige på 0,70 , for Norge så lav som 0,49 . Også her skiller Oslo seg ut, tar vi ut dette fylket fra de norske dataene er korrelasjonen på o,68, og sammenlignbar med Sverige.

I figurene 7 og 8 har vi vist to kart over Sverige og Norge for de to størrelsene. Mens det for personer per butikk kommer frem et veldig klart skille mellom landene, er dette mye mer fraværende i figuren for butikker innenfor 10 minutters reiseavstand. Vi ser mer variasjon på tvers av fylker og len og mye mindre klar variasjon som skyldes nasjonale forskjeller.

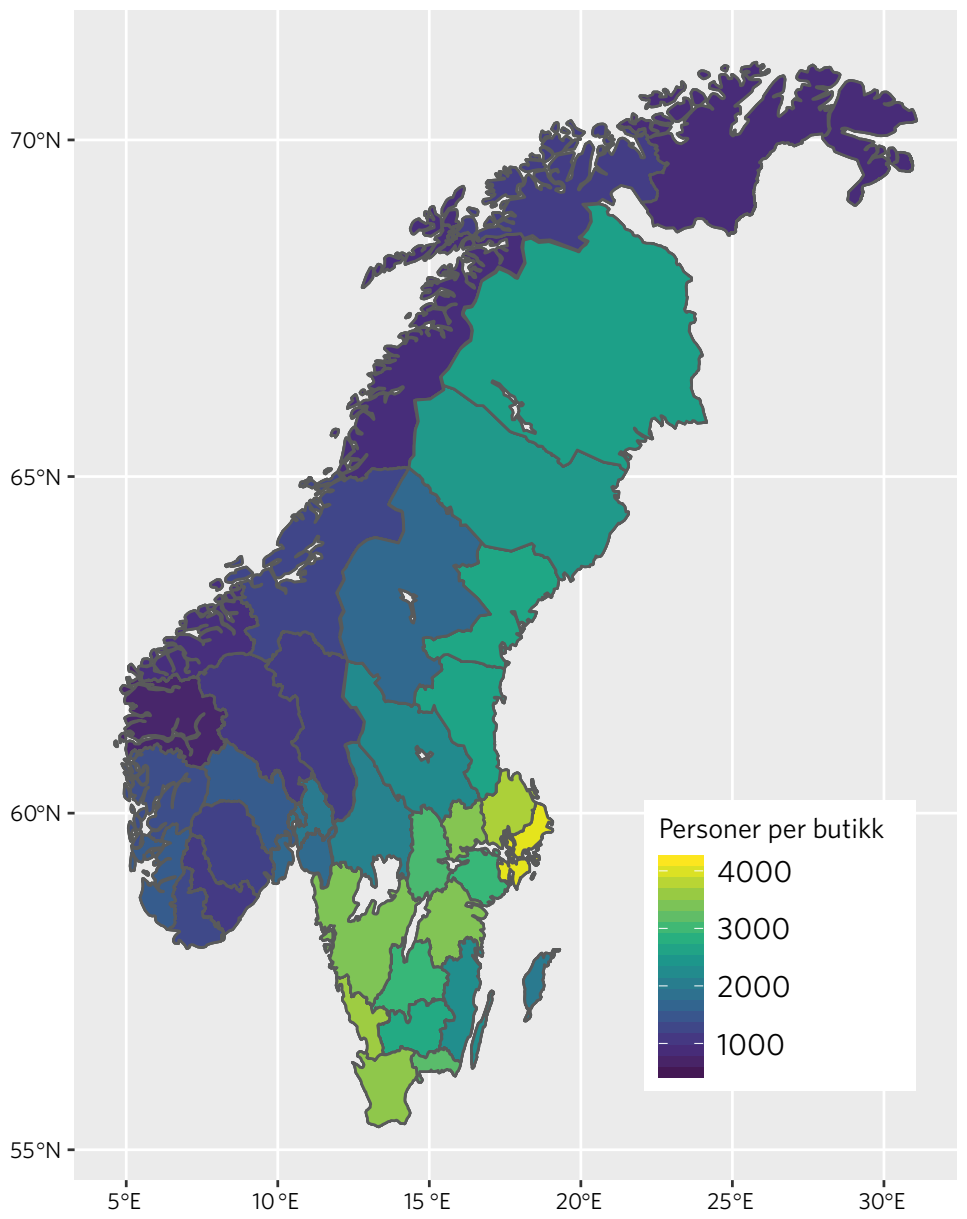

Figur 7 Personer per butikk i Norge og Sverige. 


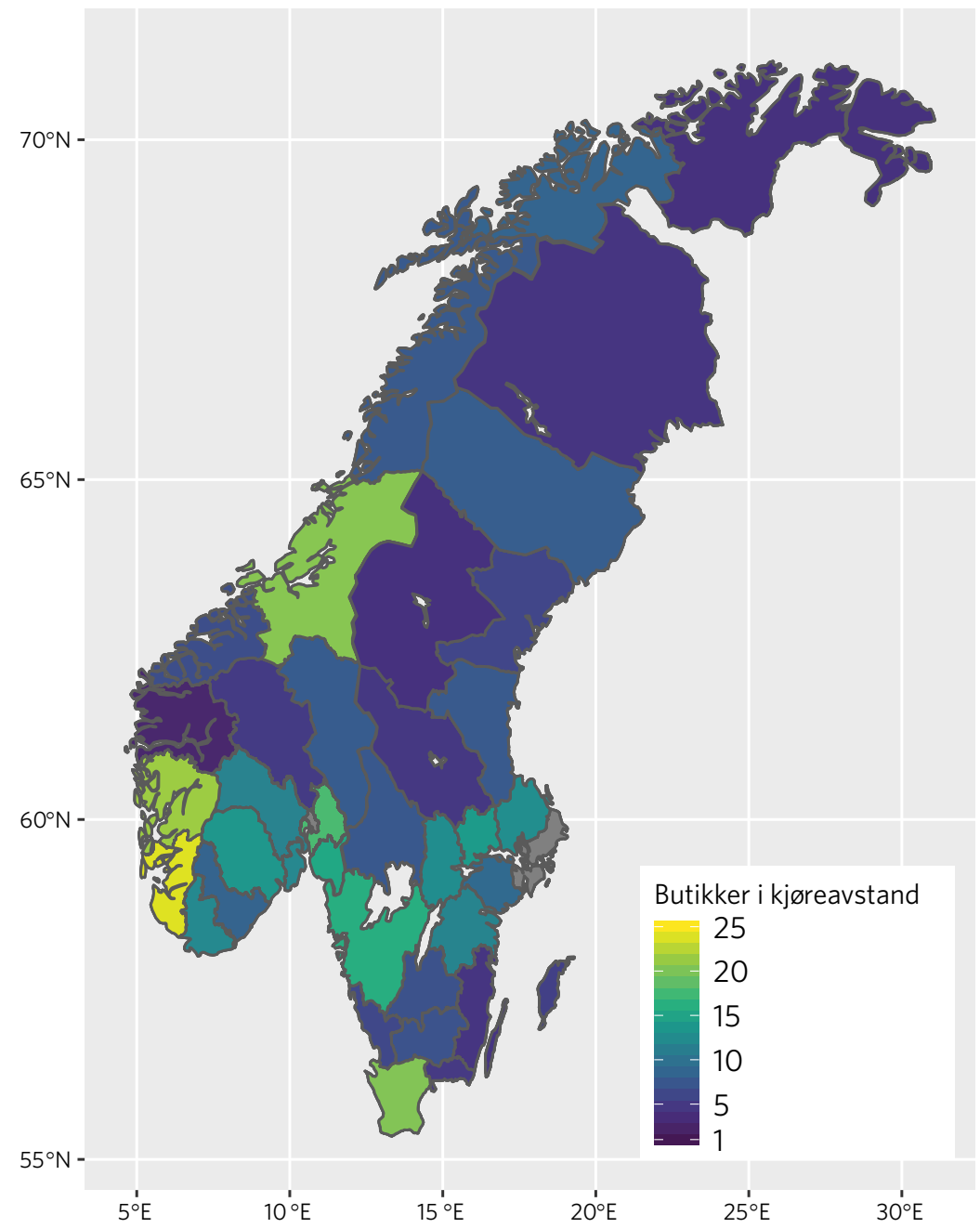

Figur 8 Antall butikker innenfor 10 minutters reiseavstand i Norge og Sverige.

I figurene 9 og 10 viser vi antall butikker innenfor 10 minutters kjøreavstand der vi konsentrerer oss om Oslo/Akershus og Stockholm. Vi ser for begge land en mye større butikktetthet sentralt i hovedstadsområdene, men mønsteret er mye skarpere mellom høy og lav butikktetthet i Stockholm. 


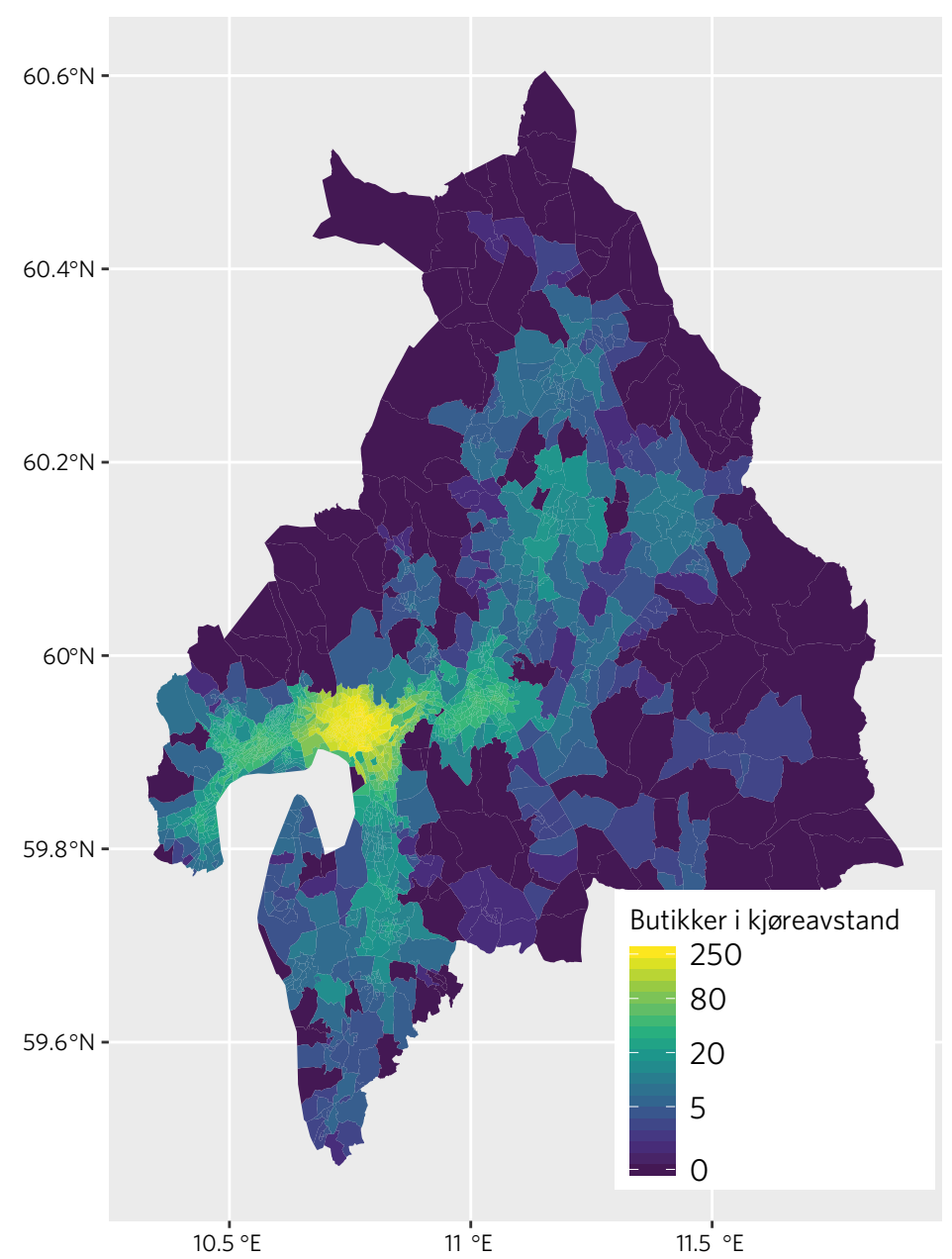

Figur 9 Antall butikker innenfor 10 minutters reiseavstand i fylkene Oslo og Akershus.

Vi ser også at de sentrale områdene av Oslo har mye høyere butikktetthet enn tilsvarende områder i Stockholm. Dette illustrerer igjen at hovedstadsområdene skiller seg kraftig ut, både innenfor sine respektive land, men enda mer på tvers av land.

Ser vi dermed bort fra Oslo og Akershus - som neppe skiller seg så mye i urbaniseringsstruktur fra Stockholm - er det nødvendig med mange flere butikker for å kunne gi nordmenn like god tilgjengelighet som svensker. Dette skyldes at vi har en helt annen topografi og et annet 


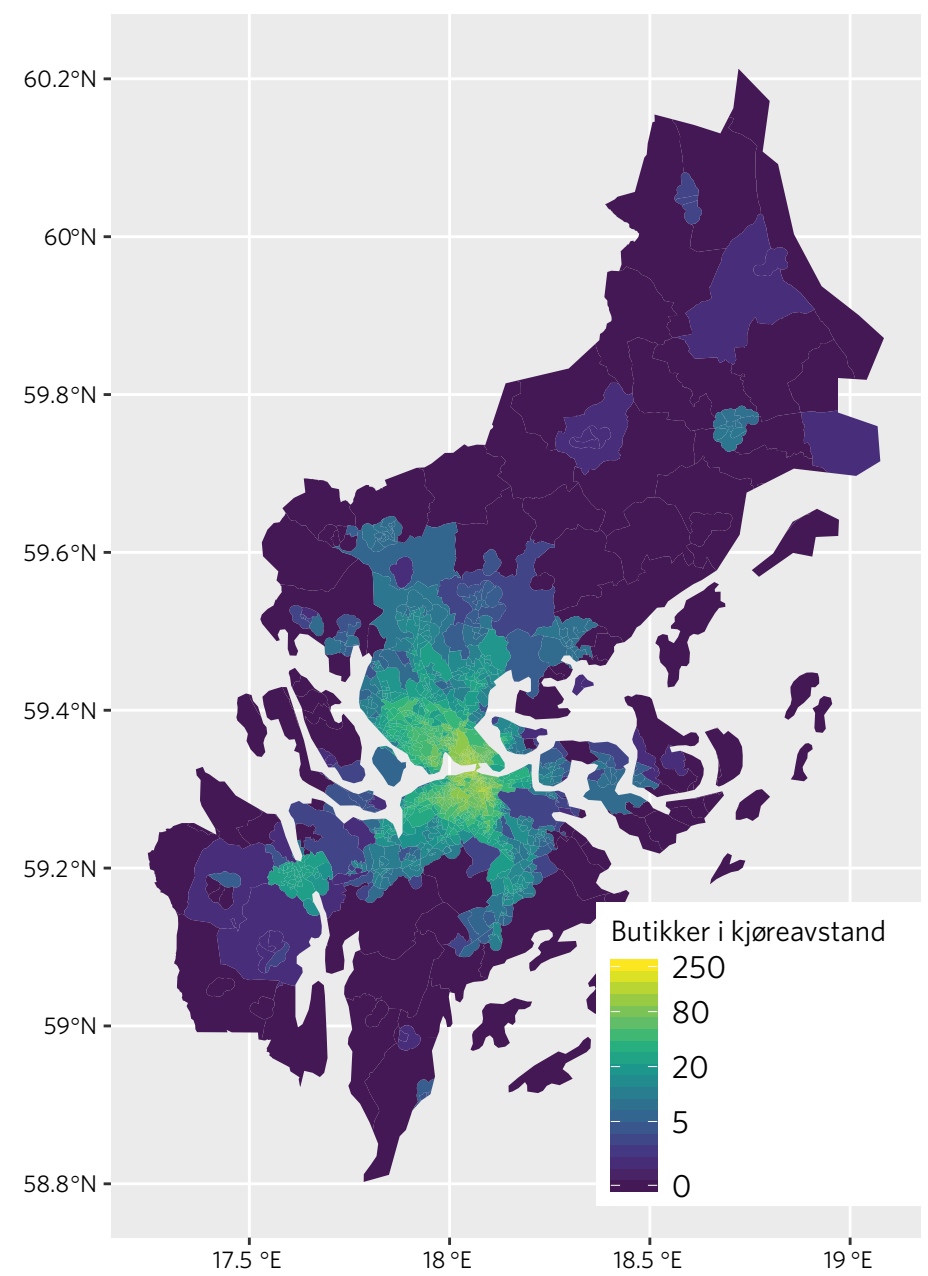

Figur 10 Antall butikker innenfor 10 minutters reiseavstand i Stockholms len.

bosettingsmønster som, koblet med det norske veinettet, sannsynligvis gjør at det simpelthen kreves flere butikker for å oppnå tilsvarende butikktilgjengelighet. Dette betyr også at det blir langt mer effektivt med større og mer kostnadseffektive butikker i Sverige.

Fokuserer vi derimot på den norske hovedstadsregionen, blir det vanskelig å skjønne at topografi eller veinett skal kunne forklare den ekstreme butikktetteheten vi observerer. Her er det opplagt rom for å ha mye færre butikker, og i så måte effektivisere distribusjonen av mat. 


\section{Markedskonsentrasjon}

I siste kolonne i tabellene 2 og 3 har vi beregnet HHI for fylker og len. Ettersom konkurransen i dagligvaremarkeder i stor grad er lokalt forankret, vil nasjonale konsentrasjonsmål kunne gi et misvisende bilde av den faktiske konkurransesituasjonen. Hvis enkelte kjeder først og fremst er aktive i noen deler av landet og andre kjeder først og fremst $i$ andre deler, vil nasjonale konsentrasjonsmål kunne overvurdere graden av konkurranse. Vi ser tegn til dette i dataene da konsentrasjonsgraden typisk er noe høyere lokalt enn for landene aggregert. Både gjennomsnittlig- og median-HHI er høyere enn de aggregerte tallene i begge land. Et annet mønster vi vil vente er at de minst urbane regionene ville ha høyere konsentrasjon da både aktører i Sverige og Norge ikke etablerer seg jevnt over hele landet. Det er imidlertid kun i Sverige vi kan se sporene av et slikt mønster.

I figur 11 viser vi sammenhengen mellom befolkning og HHI i de to landene. I Norge finner vi ingen klar sammenheng, og korrelasjonen mellom befolkningsstørrelse og HHI er bortimot null $(-0,06)$. For Sverige ser vi imidlertid en klarere negativ sammenheng. Lenene med høyest befolkningstall har lavere konsentrasjon enn de mindre lenene. Her finner vi også en negativ korrelasjon på -0,41.

Forskjellen mellom Norge og Sverige blir enda tydeligere i figur 12, hvor vi viser HHI fordelt over landene i et kartografisk bilde. Mens de høyeste HHI-lenene i Sverige finnes i Nord-Sverige, finner vi tilsvarende høye konsentrasjonstall bare på det sentrale Østlandet i Norge. I så måte er det vanskelig å se at urbaniseringsgraden og topografien kan forklare forskjellene mellom land her. Norge har fire fylker med HHI rundt 4000 eller høyere: Buskerud (HHI=4937), Hedmark (HHI=3985), Telemark $(\mathrm{HHI}=4741)$ og Vestfold $(\mathrm{HHI}=4694)$. Sverige også har fire len i denne gruppen, men disse er len med lav befolkningstetthet: Västerbotten, Norbotten, Jämtland og Gotland. Gjennomsnittsfylket med en HHI i Norge rundt 4000 eller over har 225296 innbyggere, mens i Sverige har gjennomsnittslenet med så høy HHI 175649 innbyggere. I absolutte tall er dermed disse regionene ikke så forskjellige på tvers av land, men svenske 


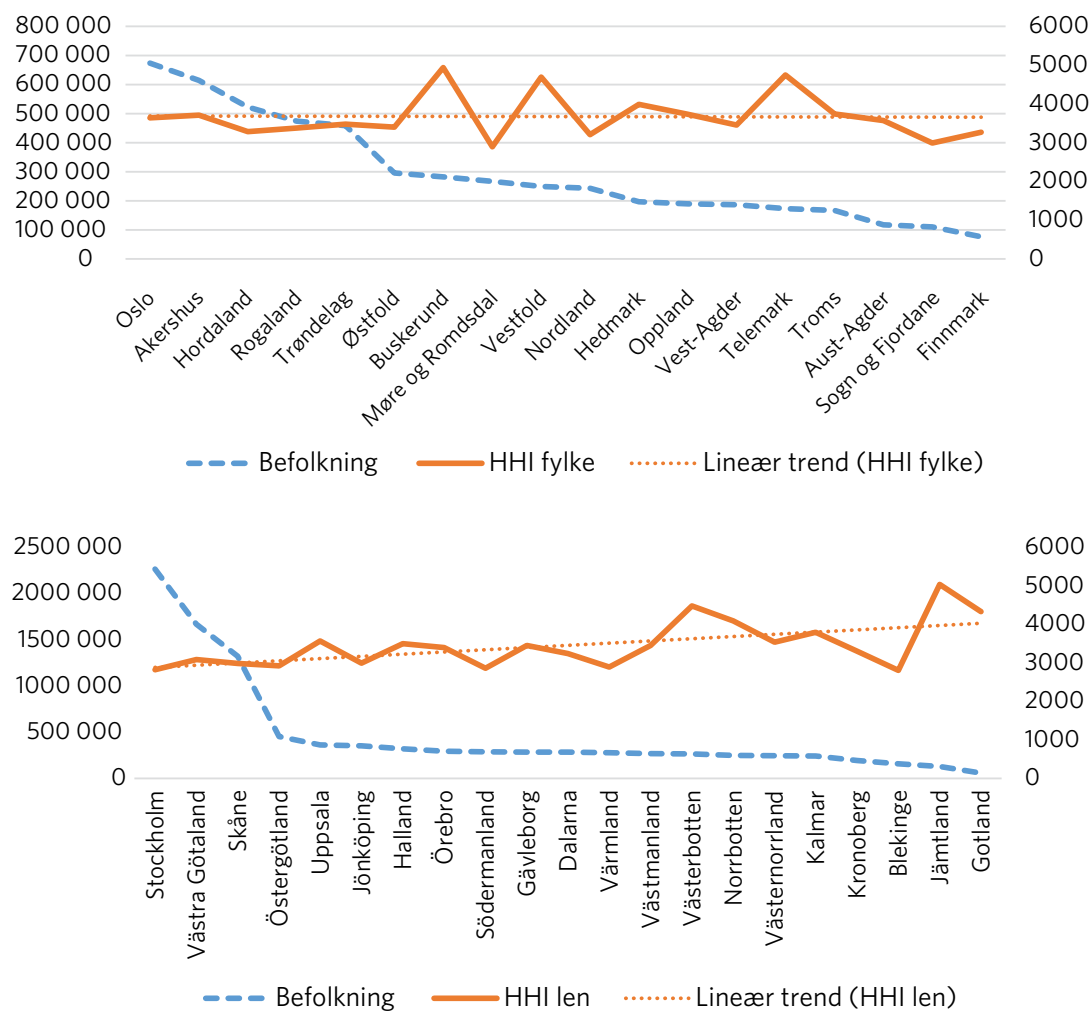

Figur 11 Befolkning og HHI på tvers av fylker og len i Norge og Sverige.

len er gjennomsnittlig nesten to ganger større enn de norske. Relativt til det norske og svenske gjennomsnittsfylket/lenet utgjør de norske høykonsentrasjonsfylkene $77 \%$ av gjennomsnittsstørrelsen av norske fylker, mens de svenske høykonsentrasjonslenene skiller seg ut med å være svært små relativt til gjennomsnittslenet, og utgjør i snitt bare $37 \%$ av gjennomsnittsstørrelsen til et svensk len. Sett i sammenheng med den langt mindre perifere plasseringen er det derfor vanskelig å se at det skulle være bosetting eller distribusjonskostnader som skulle kunne forklare forskjellene mellom fylker i Norge når det kommer til konsentrasjonsgrad. Til forskjell, så er dette en opplagt mulig forklaring på de svenske tallene. Det er også i tråd med at vi stort sett ser at utenlandske aktører 


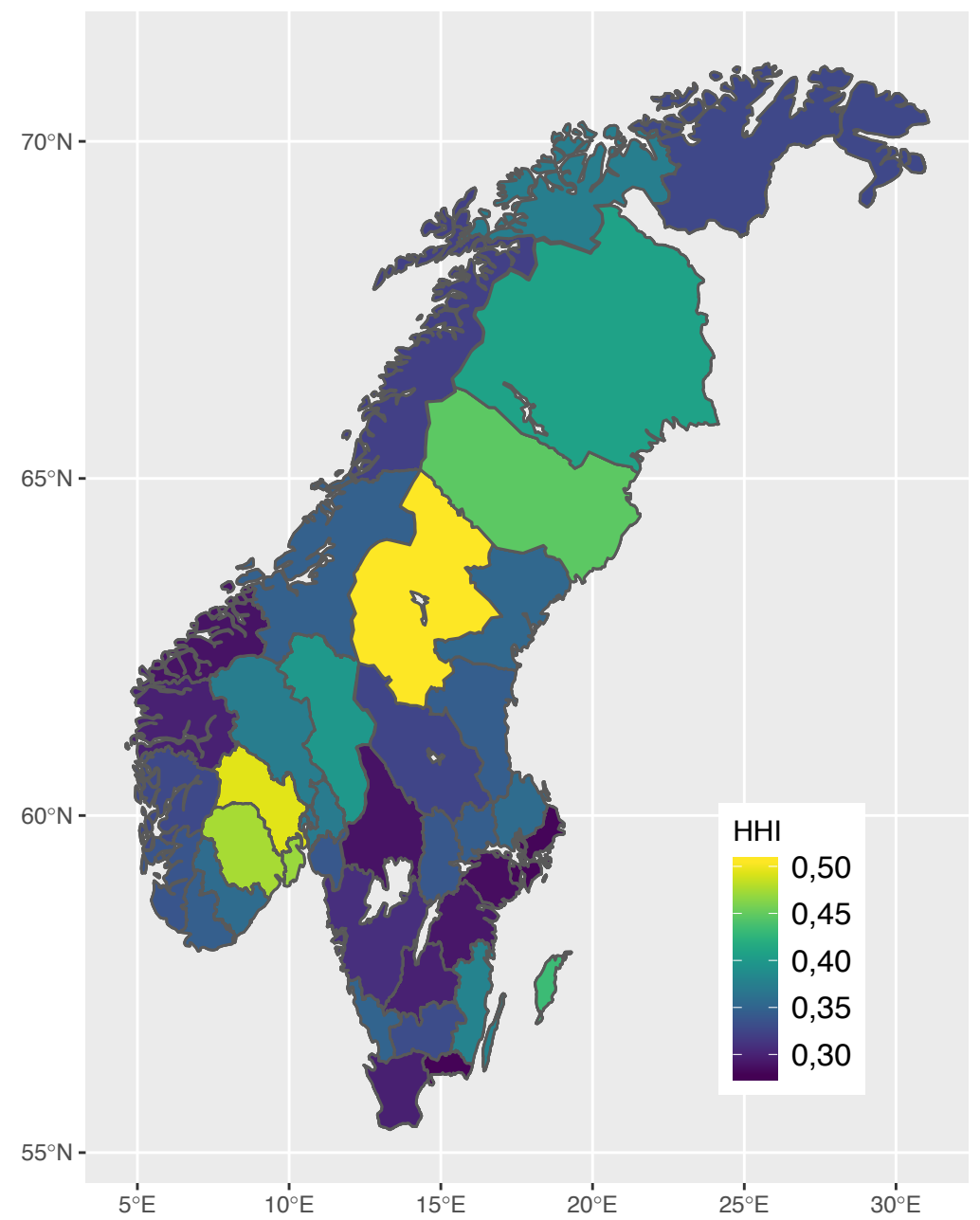

Figur $12 \mathrm{HHI}$ på tvers av fylker og len i Norge og Sverige.

som Lidl og Aldi etablerer seg i de mest urbane og befolkningsrike områdene først. ${ }^{14}$

14 Det er selvfølgelig mulige historiske årsaker til dette. Den langsiktige trenden med butikknedleggelser kan være ulik på tvers av fylker siden disse kan ha hatt i ulike utgangspunkt med hensyn til butikk- og kjedestruktur. På den annen side burde distribusjons- og effektiviseringseffekter være veldig sterke drivere for den butikkstrukturen vi sitter med i dag, slik at det ville være merkelig at konsentrasjonen regionalt ikke ble drevet av nettopp disse. 


\section{En sammenligning av Nord-Sverige og Nord-Norge}

For å ytterligere forstå betydningen av butikktetthet og konsentrasjonsgrad har vi i tabell 3 fokusert bare på Nord-Norge og de to nordligste lenene (Västerbotten og Norrbotten) i Sverige. Disse områdene er ikke så ulike på tvers av land. De utgjør omtrent en tredjedel av sine respektive land når det kommer til flateinnhold (29,3 \% i Norge, 34,3 \% i Sverige), og de er tynt befolket (4,30 innbyggere per $\mathrm{km}^{2}$ i Norge, 3,34 innbyggere per $\mathrm{km}^{2}$ i Sverige). ${ }^{15}$ I så måte burde det å tilby butikktjenester i disse områdene ikke være så forskjellig. I tabell 4 viser vi tall for disse to regionene.

Tabell 4 Befolkning, butikker, nærhets- og konsentrasjonsgrad i Nord-Norge og NordSverige (regionsgjennomsnitt er befolkningsvektet).

\begin{tabular}{|l|r|r|r|r|r|}
\hline Region & Befolkning & $\begin{array}{r}\text { Antall } \\
\text { butikker }\end{array}$ & $\begin{array}{r}\text { Personer } \\
\text { per } \\
\text { butikk }\end{array}$ & $\begin{array}{r}\text { Antall } \\
\text { butikker } \\
\text { innenfor } \\
\text { 10 min } \\
\text { reiseavstand }\end{array}$ & HHI \\
\hline Nord-Norge & & & & & \\
\hline Nordland & 243335 & 252 & 966 & 8 & 3208 \\
\hline Troms & 166499 & 142 & 1173 & 9 & 3738 \\
\hline Finnmark & 76167 & 85 & 896 & 4 & 3271 \\
\hline & 486001 & 479 & 1015 & 7 & 3406 \\
\hline Nord-Norge totalt & & & & & \\
\hline & & & & & \\
\hline Nord-Sverige & 265679 & 107 & 2483 & & 4472 \\
\hline Västerbotten & 250386 & 97 & 2581 & & 4086 \\
\hline Norrbotten & & & & 6 & 4279 \\
\hline
\end{tabular}

Når vi ser på innbyggere er regionene er omtrent jevnstore med en halv million innbyggere. Nord-Norge har likevel mer enn dobbelt så mange butikker som Nord-Sverige. Antall personer per butikk er noe lavere enn landsnittene på henholdsvis 3203 og 1397 for Sverige og Norge, men det relative forholdet er mye det samme. På landsnivå utgjør personer per

15 Västerbotten og Norrbotten utgjør $154212 \mathrm{~km}^{2}$, mens Nordland, Troms og Finnmark utgjør $112989 \mathrm{~km}^{2}$. 
butikk i Norge (1397/3203) 43,6 \% av antallet i Sverige, mens personer per butikk i Nord-Norge utgjør (1015/2530) 40,1 \% av antallet i Nord-Sverige.

Det som imidlertid er påfallende, er at både i Nord-Norge og i Nord-Sverige har gjennomsnittsinnbyggeren 6-7 butikker innenfor 10 minutters reiseavstand. Altså er tilgangen til butikker omtrent den samme i regionene.

Dette illustrerer dermed forskjellen i bosettingsmønster på tvers av land. Dels er Norge kommunikasjonsmessig mer krevende, og dels bor man lenger fra hverandre, slik at det krever 2,4 ganger flere butikker i Norge for å gi samme nærhetstilbudet som i Sverige.

Tabell 4 viser også tall for HHI. Her er regionene svært forskjellige. I Nord-Sverige er HHI i gjennomsnitt 4279, som er mye høyere enn sør i Sverige. I Nord-Norge er HHI bare på 3406, og tilforlatelig likt det norske landsgjennomsnittet. Gitt at distribusjonen av matvarer i disse regionene opplagt er mye dyrere enn sør i landene, er det overraskende at man i Norge har så bred dekning av aktørene. I Nord-Norge er alle de fire norske kjedene representert, og både Bunnpris og Rema har større andeler enn sine landssnitt (se tabell 5). I Nord-Sverige er det annerledes, der har ICA og Coop mellom 81 \% (Norrland) og $95 \%$ (Västerbotten) av markedet, og de andre aktørene er enten ikke representert, eller har små andeler. ${ }^{16}$ I den grad konsentrasjonsmål og markedsandeler avspeiler den lokale konkurransen er det dermed grunn til å tro at konkurransepresset i Nord-Norge er vesentlig høyere enn i Nord-Sverige.

\section{Markedsandeler butikker og omsetning på kjede og landsdelsnivå i Norge og Sverige}

Over så vi på butikktilgjengelighet og overordnet markedskonsentrasjon. Her vil vi se nærmere på kjedefordeling av butikker og omsetning på

16 På landsbasis har ICA og Coop 67 \% av markedet. De to neste på listen er Axfood og Bergendahl som henholdsvis har 18 og $8 \%$. I Västerbotten har Axfood $6 \%$, i Norrland $8 \%$, Bergendahl er ikke til stede i disse markedene. 
landsdelsnivå. Vi vil da kunne svare på spørsmål som: Er det slik at kjedene er likt representert over landsdeler? Hvordan er forholdet mellom kjedenes butikkandeler og deres omsetningsandeler? Vi har valgt å dele data inn i de landsdelene som Norge og Sverige selv benytter. I prinsippet kunne vi gjort analysen på fylke/len eller kommunenivå, men for å slippe å måtte forholde seg til alt for mange tall, og for få et oversiktlig bilde har vi holdt oss til landsdeler i denne analysen. Tabellene 5 og 6 viser landsdelstall for Norge og Sverige.

Tabell 5 Markedsandeler (verdi), konsentrasjonsgrad og antall butikker på tvers av landsdeler i Norge.

\begin{tabular}{|c|c|c|c|c|c|}
\hline Markedsandeler & $\begin{array}{l}\text { Norges- } \\
\text { Gruppen }\end{array}$ & Coop & Rema & Bunnpris & HHI \\
\hline Østlandet & $54,1 \%$ & $21,8 \%$ & $22,7 \%$ & $1,4 \%$ & 3923 \\
\hline Sørlandet & $44,3 \%$ & $31,2 \%$ & $23,2 \%$ & $1,3 \%$ & 3473 \\
\hline Vestlandet & $39,0 \%$ & $31,0 \%$ & $24,0 \%$ & $6,0 \%$ & 3092 \\
\hline Trøndelag & $15,5 \%$ & $49,6 \%$ & $26,6 \%$ & $8,3 \%$ & 3475 \\
\hline Nord-Norge & $25,9 \%$ & $45,4 \%$ & $24,0 \%$ & $4,7 \%$ & 3331 \\
\hline Norge & $42,6 \%$ & $30,1 \%$ & $23,6 \%$ & $3,7 \%$ & 3293 \\
\hline Butikker & $\begin{array}{c}\text { Norges- } \\
\text { Gruppen } \\
\end{array}$ & Coop & Rema & Bunnpris & $\begin{array}{r}\text { Butikker } \\
\text { Totalt } \\
\end{array}$ \\
\hline \multirow[t]{2}{*}{ Østlandet } & 890 & 386 & 296 & 48 & 1620 \\
\hline & $(54,9 \%)$ & $(23,8 \%)$ & $(18,3 \%)$ & $(3,0 \%)$ & \\
\hline \multirow[t]{2}{*}{ Sørlandet } & 125 & 74 & 37 & 6 & 242 \\
\hline & $(51,7 \%)$ & $(30,6 \%)$ & $(15,3 \%)$ & $(2,5 \%)$ & \\
\hline \multirow[t]{2}{*}{ Vestlandet } & 514 & 307 & 163 & 108 & 1092 \\
\hline & $(47,1 \%)$ & $(28,1 \%)$ & $(14,9 \%)$ & $(9,9 \%)$ & \\
\hline \multirow[t]{2}{*}{ Trøndelag } & 81 & 156 & 71 & 50 & 358 \\
\hline & $(22,6 \%)$ & $(43,6 \%)$ & $(19,8 \%)$ & $(14,0 \%)$ & \\
\hline \multirow[t]{2}{*}{ Nord-Norge } & 163 & 209 & 77 & 30 & 479 \\
\hline & $(34,0 \%)$ & $(43,6 \%)$ & $(16,1 \%)$ & $(6,3 \%)$ & \\
\hline \multirow[t]{2}{*}{ Norge } & 1773 & 1132 & 644 & 242 & 3791 \\
\hline & $(46,8 \%)$ & $(29,9 \%)$ & $(17,0 \%)$ & $(6,4 \%)$ & \\
\hline
\end{tabular}


KAPITTEL 2

Tabell 6 Markedsandeler (verdi), konsentrasjonsgrad og antall butikker på tvers av landsdeler i Sverige.

\begin{tabular}{|l|r|r|r|r|r|r|r|}
\hline Markedsandeler & ICA & Coop & Axfood & Bergendahls & Lidl & Andre & HHI \\
\hline Svealand & $45,1 \%$ & $19,8 \%$ & $19,7 \%$ & $8,3 \%$ & $4,9 \%$ & $2,3 \%$ & 2906 \\
\hline Götaland & $48,5 \%$ & $16,3 \%$ & $18,6 \%$ & $8,6 \%$ & $4,0 \%$ & $4,1 \%$ & 3066 \\
\hline Norrland & $53,8 \%$ & $29,9 \%$ & $11,3 \%$ & $1,4 \%$ & $2,9 \%$ & $0,7 \%$ & 3927 \\
\hline & & & & & & & \\
\hline Sverige & $47,8 \%$ & $19,4 \%$ & $18,1 \%$ & $7,6 \%$ & $4,2 \%$ & $3,0 \%$ & 3066 \\
\hline & & & & & & & \\
\hline Butikker & ICA & Coop & Axfood & Bergendahls & Lidl & Andre & $\begin{array}{r}\text { Butikker } \\
\text { Totalt }\end{array}$ \\
\hline & & & & & & & 1186 \\
\hline Svealand & 435 & 282 & 236 & 60 & 89 & 84 & \\
\hline & $(36,7 \%)$ & $(23,8 \%)$ & $(19,9 \%)$ & $(5,1 \%)$ & $(7,5 \%)$ & $(7,1 \%)$ & \\
\hline Götaland & 560 & 250 & 280 & 65 & 83 & 215 & 1453 \\
\hline & $(38,5 \%)$ & $(17,2 \%)$ & $(19,3 \%)$ & $(4,5 \%)$ & $(5,7 \%)$ & $(14,8 \%)$ & \\
\hline Norrland & 241 & 139 & 47 & 3 & 16 & 30 & 476 \\
\hline & $(50,6 \%)$ & $(29,2 \%)$ & $(9,9 \%)$ & $(0,6 \%)$ & $(3,4 \%)$ & $(6,3 \%)$ & \\
\hline & & & & 128 & 188 & 329 & 3115 \\
\hline Sverige & $(39,7 \%)$ & $(21,5 \%)$ & $(18,1 \%)$ & $(4,1 \%)$ & $(6,0 \%)$ & $(10,6 \%)$ & \\
\hline & & & & & & & \\
\hline
\end{tabular}

Ser vi på Norge først, er det en del slående forskjeller når det kommer til kjedenes posisjon i de ulike landsdelene. For det første har NorgesGruppen svært ulik posisjon på tvers av landsdeler. Landssnittet på $43 \%$ avspeiler en variasjon på 38,7 prosentpoeng. I Trøndelag har NorgesGruppen $15,5 \%$ av markedet, men kjeden er dominerende på Østlandet med en markedsandel på 54,1\%. I Nord-Norge står de relativt svakt med 25,9\% av markedet. Et motsvarende bilde viser seg i Coop-tallene. Bak deres landssnitt på 30,1 \% skjuler det seg en variasjon på 27,8 prosentpoeng. På Østlandet har de bare 21,8 \% av markedet, mens de i Trøndelag har rundt halvparten med 49,6\%. I Nord-Norge har Coop en markedsandel på 45,4\%. Rema 1000 har sin største andel i Trøndelag med 26,6\%, men er ikke mindre enn 22,7 \% i noe marked. Bunnpris har sin sterkeste posisjon i Trøndelag $(8,3 \%)$ og på Vestlandet (6\%), mens de knapt er til stede på Øst- og Sørlandet. 
Denne variasjonen leder til at konsentrasjonen i landsdelsmarkedene er større enn den nasjonale, med unntak av Vestlandet. I tillegg er det nærmest en «markedsdeling» mellom NorgesGruppen og Coop, der NorgesGruppen er størst i alle landsdelene sør for Trøndelag, mens Coop er den store fra Trøndelag og nordover. Overraskende nok er Østlandet det mest konsentrerte landsdelsmarkedet av alle, med en HHI på nesten 4000.

Fokuserer vi på butikk-konsentrasjon er denne parallell til det vi ser for omsetning, men med noen viktige forskjeller. For det første har NorgesGruppen høyere butikkandeler enn markedsandeler. De har nesten $47 \%$ av butikkene i Norge, men kun $43 \%$ av omsetningen. I fire av landsdelene har de mellom 7 og 8 prosentpoeng høyere butikkandel enn omsetningsandel. Dette skyldes opplagt at de har mange mindre Spar- og Joker butikker, og dermed lavere omsetning per butikk. På den annen side skiller de seg fra Coop, som også har en rekke mindre butikk-konsept. Coop har mye mindre ulikheter i butikkandeler og omsetningsandeler, og i den grad de har avvik, som i Trøndelag, er avvikene positive i 5 av 6 tilfeller. Rema 1000 har på sin side mye høyere omsetningsandeler enn butikkandeler. På landsbasis er omsetningsandelen 7 \% høyere enn butikkandelen, på Vestlandet hele 9 prosentpoeng høyere. Selv på Østlandet har de mer enn 4 prosentpoeng høyere omsetningsandel. Dette avspeiler selvfølgelig at de typisk har mer homogene og større butikker enn de andre. Bunnpris ligner på sett og vis mest på NorgesGruppen, i den forstand at de typisk har lavere omsetnings- enn butikkandeler. Dette er imidlertid enklere å forstå for Bunnpris, som i all hovedsak har små butikker. Den største forskjellen for Bunnpris er i Trøndelag der de har sin største omsetningsandel $(8,3 \%)$ men faktisk har så mye som $(14 \%)$ av butikkene.

For å forstå disse forskjellene bedre har vi i tabell 7 vist gjennomsnittlig butikkstørrelse fordelt på land og kjeder. Tallene for Norge avspeiler i stor grad forskjellene i butikk- og omsetningsandeler. Gjennomsnittsbutikken i Norge har $718 \mathrm{~m}^{2}$, og både NorgesGruppen og Bunnpris har gjennomsnittlig mindre butikker. Mens Coop-snittet ligger nærmest gjennomsnittsbutikken, har NorgesGruppen og Bunnpris 14-17 \% mindre butikkstørrelse, med tilsvarende lavere omsetnings- enn butikkandeler. For Bunnpris er det mye mer markert, mens butikkene deres bare 
er $17 \%$ mindre enn gjennomsnittet er omsetningsandelen $73 \%$ lavere enn butikkandelen. Butikkstørrelsesforskjellene forklarer langt på vei forskjellene vi fant mellom NorgesGruppen og Coop over. Coop har svært like omsetnings- og butikkandeler, og butikkene deres er på landsnittet størrelsesmessig. Rema 1000 gjennomsnittsbutikk er hele 39 \% større enn gjennomsnittsbutikken, noe vi ser igjen i at omsetningsandelen er $28 \%$ større enn butikkandelen deres.

Tabell 7 Gjennomsnittlig butikkstørrelse i $\mathrm{m}^{2}$ i Sverige og Norge. (Kilde: Delfia og Geodata, vektede landsnitt)

\begin{tabular}{|c|c|c|c|c|c|c|}
\hline Sverige & ICA & Coop & Axfood & Bergendahls & Lidl & Andre \\
\hline 1161 & 1087 & 1181 & 1256 & 3156 & 1114 & 453 \\
\hline Norge & NorgesGruppen & Coop & Rema 1000 & Bunnpris & & \\
\hline 718 & 618 & 744 & 996 & 599 & & \\
\hline
\end{tabular}

Ser vi nå på Sverige (tabell 6) er det både likheter og forskjeller. ${ }^{17}$ For det første er ICA alltid størst med hensyn til omsetning og har gjennomgående rundt halve markedet, med en variasjonsbredde mellom laveste og høyeste andel på $9 \%$ mellom Svealand, der de er minst, og Norrland der de er størst. Coop har størst variasjon i forhold til en nasjonal markedsandel på 19,4 \% der de kun har 16,3 \% i Götaland mens de har neste tredjedelen av markedet i Norrland (29,9\%). Det mest slående med de andre aktørene er at de har veldig mye lavere andeler i Norrland enn ellers i Sverige. Axfood har bare halvparten av sin nasjonale andel på 18,1 \% i Norrland, mens Bergendahl nærmest er ikke-eksisterende der. Også Lidl og andre viser et slikt mønster. Spesielt for Bergendahls skyldes nok deres «fravær» i Norrland deres veldig mye større butikkonsept med en gjennomsnittsstørrelse på butikkene som er bortimot tre ganger større enn både ICA og Coop sine butikker og derfor trenger et stort lokalt kundegrunnlag (tabell 7). Forskjellen mellom markedsandelen for små og store kjeder i ulike svenske regioner støtter dermed en hypotese om at det er enklest å etablere seg

17 Svealand består av lenene Stockholm, Uppsala, Södermanland, Värmland, Örebro, Västmanland og Dalarna. Götaland består av lenene Östergötland, Jönköping, Kronoberg, Kalmar, Gotland, Blekinge, Skåne, Halland og Västra Götaland. Norrland består av lenene Gävleborg, Västernorrland, Jämtland, Västerbotten og Norrbotten. 
i tett befolkede områder. At vi ikke ser dette mønstret i Norge, kan også være en indikasjon på at etableringshindringene er relativt store i Norge.

Også i Sverige er det et mønster i konsentrasjonsgraden, der konsentrasjonen her er høyest i Norrland som representere de minst urbane områdene i Sverige. Her er HHI nesten 400o, noe vi interessant nok kun fant for sentrale Østlandet i Norge. De andre to svenske landsdelene er par med HHI på nasjonalt svensk nivå. At distribusjonskostnader påvirker butikkstruktur og kjedeutbredelse i mindre urbane strøk synes lettere å forstå enn at konsentrasjonen - og slik sett konkurransetrykket - i Norge er lavest der flest nordmenn er bosatt.

Når det kommer til butikkstørrelse, har Sverige større butikker enn i Norge. Gjennomsnittsbutikken i Norge utgjør bare $62 \%$ av den svenske gjennomsnittsbutikken. ${ }^{18}$

Butikkstørrelse ser også her ut til å forklare mye av asymmetrien mellom butikk- og omsetningsandeler. Ser vi på enkeltkjeder er Sveriges største kjede ICA i motsatt situasjon av NorgesGruppen, der de har langt lavere butikkandeler enn omsetningsbaserte markedsandeler. Interessant nok er dette vanskelig å se ut fra variasjonen i butikkstørrelse. ICAs gjennomsnittsbutikk er også mindre enn den svenske gjennomsnittsbutikken (med $6 \%$ ), mens omsetningsandelen er $17 \%$ høyere enn butikkandelen, noe som synes å antyde at de selger mer per butikk $\left(\mathrm{m}^{2}\right)$ enn de andre svenske aktørene.

Butikkstørrelse forklarer også at "Andre» i Sverige har mye høyere butikkandeler enn omsetningsandeler, der deres butikker er $60 \%$ mindre enn det svenske landsgjennomsnittet. I Götaland har «Andre» en butikkandel på nesten $15 \%$, men en omsetningsandel på kun vel $4 \%$. Nasjonalt har de nesten $11 \%$ av butikkene, men kun $3 \%$ av omsetningen. I tillegg til å ha mindre butikker, finner vi i denne kategorien en rekke mindre og dels uavhengige aktører. Slik sett ser vi at aktører med små butikker har omsetningsandeler som til dels er mye mindre enn butikkandelene,

18 Dette skyldes nok mange faktorer, og vi har ikke tall til å si noe om dette her. Eksempler på forhold som typisk dras frem er ut over et mer urbanisert bosettingsmønster, lengre åpningstider (åpen også søndager), potensielle forskjeller i lokale reguleringsforhold og forskjellige handlevaner. Mens nordmenn synes å handle mindre og ofte, handler svensker mer og sjeldnere. I hvilken grad forskjeller i handlemønsteret er skapt av opprinnelige ulike kundepreferanser, eller gjennom ulike historiske butikkstrukturer er imidlertid vanskelig å mene noe om. 
og også mindre enn butikkstørrelsen skulle tilsi. Dette gjenspeiler det vi fant for Bunnpris i Norge. Dette avspeiler trolig en ikke-linearitet mellom butikkstørrelse og omsetning. Små butikker selger både et smalere utvalg og har mye mindre handlekurver enn de større butikkene.

Lidl har også en mismatch mellom omsetnings- og butikkandel, der omsetningsandelen er $43 \%$ mindre enn butikkandelen. Samtidig er den gjennomsnittlige Lidlbutikken i Sverige på $1114 \mathrm{~m}^{2}$, bare så vidt mindre enn snittbutikken på $1161 \mathrm{~m}^{2}$, noe som nok avspeiler deres lavpriskonsept («hard discount»).

På den andre siden av spekteret har vi Bergendahl med sine mye større butikker, som dermed også har mer omsetning per butikk. Som at de mindre butikkene ikke klarer å ta ut omsetning relativt til butikkstørrelse ser det ut som at det er vanskelig å få ut full effekt av butikkstørrelse for de store butikkene i tilsvarende omsetning. Mens omsetningsandelen er $46 \%$ høyere enn butikkandelen, er gjennomsnittsstørrelsen på en Bergendahlbutikk neste tre ganger $(2,72)$ større enn den svenske gjennomsnittsbutikken.

Sammenligner vi de to landene ser vi dermed at Sverige har mindre variasjon på tvers av landsdeler når det kommer til sammensetning av aktører. I Norge bytter NorgesGruppen og Coop på å være størst, der NorgesGruppen dominerer sør for Trøndelag mens Coop dominerer Nord- og Midt-Norge. ICA og Coop i Sverige er derimot typisk store og til stede på tvers av landsdelene. Ser vi på resten av aktørene er det også forskjeller. I Norge har spesielt Rema 1000 og dels Bunnpris et tilbud over hele landet, også i nord, mens i Sverige er de mindre aktørene enten ikke til stede eller mye mindre til stede i Norrland. Generelt er Norge mer konsentrert, både nasjonalt og i landsdelene. I Sverige øker ikke konsentrasjonen så mye når vi disaggregerer på regionsnivå som i Norge.

Ser vi på butikk- og omsetningsandeler, er også landskapet forskjellig. I Sverige er ICA som dominerende kjede vesentlig større i omsetning enn i antall butikker, også når vi tar høyde for gjennomsnittlig butikkstørrelse. Det motsatte er tilfelle for NorgesGruppen i Norge. NorgesGruppen har typisk høyere butikkandel enn omsetningsandel, noe som bare dels kan forklares med at de har mindre størrelse på butikkene. Med tanke på at både ICA og NorgesGruppen dominerer sine respektive land 
er forskjellen mellom kjedene tilsynelatende at omsetningsmessig gjør ICA det bedre både når vi kontrollerer for antall butikker og størrelse på butikkene.

\section{Konklusjon}

På tross av en utvikling der antall butikker er kraftig redusert over tid, har Norge fremdeles flere butikker enn våre naboland. Ser vi på forholdet mellom befolkning og antall butikker og sammenligner med Sverige, blir forskjellene enda større. Vi har her estimert et nytt mål for lokalbutikktilgjengelighet: antall butikker innenfor 10 minutters reiseavstand. Aggregert opp på fylkes- og lensnivå gir dette målet mye mindre forskjeller mellom Sverige og Norge enn det man finner ved å se på antall personer per butikk.

Spesielt gjelder dette utenfor hovedstadsregionene. Resultatene våre viser dermed at det er nødvendig med mange flere butikker for å kunne gi nordmenn like god tilgjengelighet som svensker. Dette skyldes trolig forskjeller i topografi og bosettingsmønster, koblet med et veinett som trolig innebærer at det kreves flere butikker for å oppnå tilstrekkelig butikktilgjengelighet for norske husholdninger. Dette innebærer trolig også at det blir mer effektivt med større og mer kostnadseffektive butikker i Sverige.

Den norske hovedstadsregionen skiller seg imidlertid kraftig ut, både i forhold til andre fylker og len generelt, men også i forhold til Stockholmsregionen. Mens en stockholmer har 35 butikker innenfor 10 minutters reiseavstand, har en osloborger 137, og tar vi med de som bor i Akershus faller ikke det vektede gjennomsnittet til mindre enn 8o. Siden det er mye som taler for at urbaniseringsstrukturen i Oslo og Akershus og Stockholms len er mye lik, tyder dette på en overetablering av dagligvarebutikker i Oslo.

Ser vi på markedskonsentrasjon på detaljnivå, skiller Norge seg noe fra sine naboer. Når det kommer til nivå er vi par med Sverige og Finland, men ikke med Danmark som har opplevd redusert konsentrasjon i detaljmarkedet siden 2011. Fra å ha hatt lavest konsentrasjon blant de nordiske landene i 2011, har norsk konsentrasjonsnivå målt gjennom 
Herfindahl-Hirschman-indeksen økt med $24 \%$ frem til 2018. Konsentrasjonsnivået målt i 2018 er høyt for alle landene i sammenligningen, for de tre landene som ligger høyest ligger konsentrasjonsnivået godt over EUs høyeste «bekymringsnivå». På den annen side er det et typisk trekk at de tre nordiske markedene med desidert lavest folketetthet - og klart mest kostbar distribusjon av dagligvarer - alle har jevnstore, høye konsentrasjonsnivåer.

En annen forskjell er at mens de høyeste «HHI-lenene» i Sverige finnes i Nord-Sverige, finner vi tilsvarende høye konsentrasjonstall bare på det sentrale Østlandet i Norge. Norge har fire fylker med HHI rundt 4000 eller over (Buskerud, Hedmark, Telemark og Vestfold), mens Sverige også har fire len i denne gruppen, men disse er «mer perifere» len med lav befolkningstetthet: Västerbotten, Norbotten, Jämtland og Gotland. Høyere regionale distribusjonskostnader i områder med lav befolkningstetthet kan tenkes som en forklaring på heterogeniteten $\mathrm{i}$ konsentrasjon og kjedetilstedeværelsen i Sverige, men kan vanskelig fungere som forklaringsmodell for de norske tallene. At distribusjonskostnader påvirker butikkstruktur og kjedeutbredelse i mindre urbane strøk, synes lettere å forstå enn at konsentrasjonen - og sånn sett konkurransetrykket i Norge, er lavest der flest nordmenn er bosatt.

For bedre å forstå fylkes- og lensresultatene zoomer vi i tillegg inn på Nord-Norge og Nord-Sverige. Disse regionene er omtrent jevnstore med en halv million innbyggere, og de utgjør om lag en tredjedel av sine respektive lands landområder. Nord-Norge har mer enn dobbelt så mange butikker som Nord-Sverige. Det som imidlertid er påfallende, er at både i Nord-Norge og i Nord-Sverige har gjennomsnittsinnbyggeren 6-7 butikker innenfor 10 minutters reiseavstand. Altså er tilgangen til butikker den omtrent den samme i regionene. Dette illustrerer dermed forskjellen i bosettingsmønster på tvers av land. Dels er Norge kommunikasjonsmessig mer krevende, og dels lever man lengre fra hverandre, slik at det kreves 2,4 ganger flere butikker i Nord-Norge for å gi samme nærhetstilbudet som i Nord-Sverige.

I siste del har vi sett på landsdeler på tvers av Norge og Sverige, og sammenligner butikk- og omsetningsandeler for paraplykjedene. Sverige har mindre variasjon på tvers av landsdeler når det kommer til 
sammensetning av aktører. I Norge bytter NorgesGruppen og Coop på å være størst, der NorgesGruppen dominerer sør for Trøndelag, mens Coop dominerer Nord- og Midt-Norge. ICA og Coop i Sverige er derimot typisk store og til stede på tvers av landsdelene. Ser vi på resten av aktørene er det også forskjeller. I Norge har spesielt Rema 1000 og dels Bunnpris et tilbud på tvers av hele landet, også i nord, mens i Sverige er de mindre aktørene enten ikke til stede eller mye mindre til stede i Norrland.

I Sverige er ICA som dominerende kjede vesentlig større i omsetning enn i antall butikker, også i forhold til sin gjennomsnittlige butikkstørrelse. NorgesGruppen har ikke tilsvarende rolle i Norge, og selv om man tar høyde for butikkstørrelse har de relativt sett mindre omsetningsandeler enn butikkandeler. Noe av forklaringen på forskjellen i butikkstørrelse mellom land, og muligens også for de lavere omsetningsandelen i norske butikker, er nok også at store deler av norske konsumenter bor nær nok Sverige til å kunne handle i svenske grensesupermarked. Mer enn $40 \%$ av norske konsumenter bor innen 90 minutters kjøreavstand til Norge, og innenfor denne gruppen svarer mer enn halvparten at de handler i Sverige (Friberg, Steen \& Ulsaker, 2019). Prisnivået er som vist også i kapittel 4 (Pettersen, 2020) i størrelsesorden 30 \% lavere i Sverige, noe som gjør at grensehandelen har vokst seg betydelig over tid, og utgjør kanskje så mye som 10 \% av norsk dagligvareomsetningen per 2019. Dette reduserer trolig etterspørselen etter større supermarked i Norge, og da spesielt i folkerike områder som på Østlandet og regionen rundt Oslo.

For begge land ser vi videre at det synes å være en ikke-lineær sammenheng mellom butikk- og omsetningsandeler. Kjedene med færrest butikker omsetter enda mindre enn hva størrelse og butikktetthet skulle tilsi, og tilsvarende ser det ut som at kjedene med størst butikker ikke klarer å ta dette ut i tilsvarende stor omsetning i forhold til butikktetthet og arealstørrelse.

Analysen i denne artikkelen har sett på markedsandeler og butikktilgjengelighet, uten å ta hensyn til forskjeller i kvalitet og vareutvalg som opplagt også påvirker konkurranseintensiteten i et marked (Sexton, 2013). Tilsvarende har vi sett bort fra dagligvarer som selges gjennom «convenience-stores», som eksempelvis kiosker og bensinstasjoner, og 
slik sett ikke tatt hensyn til mulige regionale og nasjonale forskjeller som skyldes ulike strukturer i dette markedet.

Takk for nyttige kommentarer til Olvar Bergland og Per Ingvar Olsen.

\section{Referanser}

ACNielsen. (2000). Strukturrapport dagligvareregisteret 2000 (juni 2000).

ACNielsen. (2002-2016). Dagligvarerapporten 2002-2016.

Dagligvarukartan. (2012-2019). Delfi, DLF og Fri Köpmanskap,

Konkurransetilsynet. (2019). Kartlegging av innkjøpsbetingelser i norsk dagligvaresektor. Hentet fra https://konkurransetilsynet.no/wp-content/ uploads/2019/11/Rapport-om-innkj\%C3\%B8psbetingelser_2019.pdf

Friberg, R., Steen, F. \& Ulsaker, S. A. (2019). Hump-shaped cross-price effects and the extensive margin in cross-border shopping. DP 29, Institutt for samfunnsøkonomi, Norges Handelshøyskole. Hentet fra http://hdl.handle.net/11250/2578608 Utgis snart i American Economic Journal: Microeconomics.

Jensen, T. B. \& Skogli, E. (2016). Utvalget av mat og drikke i norsk og svensk dagligvare - en analyse av sammenlignbare butikker (Menon rapport 1/56). Hentet fra https://www.menon.no/wp-content/uploads/2016-56-Utvalget-av-mat-ogdrikke-i-svensk-og-norsk-dagligvare.pdf

Nordic Competition Authorities. (2005). Nordic food markets: A taste for competition (Rapport fra de nordiske konkurransemyndighetene 1/2005). Hentet fra http:// www.konkurrensverket.se/globalassets/english/publications-and-decisions/ nordic-food-markets--a-taste-for-competition.pdf

Pettersen, I. (Red.). (2008). Dagligvarehandel og mat 2008 (Norsk institutt for landbruksøkonomisk forskning rapport 1/2008, prosjekt Fo37). Hentet fra https://nibio.brage.unit.no/nibio-xmlui/bitstream/handle/11250/2488825/NILFRapport-2008-01.pdf?sequence $=2$ \&isAllowed $=y$

Pettersen, I. (2020). Priser og marginer i verdikjeden for matvarer. I F. Steen \& I. Pettersen (Red.), Mot bedre vitende i norsk matsektor (Kap. 4, s. 124-157). Oslo: Cappelen Damm Akademisk.

Sexton, R. J. (2013). Market power, misconceptions, and modern agricultural markets. American Journal of Agricultural Economics, 95(2), 209-219. 


\title{
KAPITTEL 3
}

\section{Produktivitetsutvikling i norsk matsektor}

\author{
Ivar Pettersen
}

Norsk Institutt for Bioøkonomi, NIBIO

\section{Frode Steen}

\author{
Norges Handelshøyskole, NHH
}

\section{Simen A. Ulsaker}

Norges Handelshøyskole, NHH

\begin{abstract}
This chapter examines productivity changes in the Norwegian grocery industry. We analyze three levels in the vertical chain: the food industry, wholesale and distribution, and the retail level. We provide new, updated numbers on labor productivity change up until 2017. Generally, and in line with all other industry and service sectors, labor productivity growth has decreased the last ten years. The retail sector (and partly the primary producers, not analyzed in detail here) have the highest productivity growth by far, but the food industry has increased its productivity growth the last decade, following forty years of low growth. The wholesale and distribution level seems to have a weaker productivity growth in the last ten years. We point to various sources of productivity growth in the grocery industry, and discuss potential implications of the observed productivity growth patterns. Our analysis shows that this kind of productivity analysis is very sensitive to data like choices of price indexes, labor measures and aggregation levels, and clearly point to weaknesses in publicly available information and a lack of sufficiently detailed data on this industry.
\end{abstract}

Keywords: labor productivity, food industry, wholesale and distribution, grocery retail, productivity growth, food prices, food supply chains

Sitering av denne artikkelen: Pettersen, I., Steen, F. \& Ulsaker, S. A. (2020). Produktivitetsutvikling i norsk matsektor. I F. Steen \& I. Pettersen (Red.), Mot bedre vitende i norsk matsektor (Kap. 3, s. 71-123). Oslo: Cappelen Damm Akademisk.

https://doi.org/10.23865/noasp.93.ch3

Lisens: CC BY-ND 4.0. 


\section{Innledning}

I denne artikkelen skal vi primært drøfte vekst i arbeidsproduktivitet. Produktivitet er, enkelt sagt, produsert mengde per enhet innsatsfaktor. Arbeidsproduktivitet er bearbeidingsverdi eller i nasjonalregnskapet bruttoprodukt - dividert med arbeidsinnsats. Artikkelen handler om endringer i arbeidsproduktivitet i matindustri og dagligvarehandel.

Matsektoren er en stor sektor i norsk økonomi. Verdikjeden er relativt komplett fra avls- og fôrindustri til norskeide distribusjonsledd. Norske verdikjeder står for den dominerende delen av omsetningen av mat og næringsmidler i Norge, og Norge er en stor sjømateksportør. Primærproduksjonen av matråvarer for det norske markedet utgjør en liten del av norsk verdiskaping, men matindustrien er den største enkeltsektoren innenfor norsk industri, og dagligvarehandel tilsvarende innenfor varehandelen.

Siden 1970-tallet har veksten i arbeidsproduktiviteten vært ganske jevn, men det siste tiåret viser fallende vekst for næringslivet inklusive matsektoren. Den brede trenden i produktivitetsveksten tyder på at det er sammenheng mellom produktivitetsvekst på tvers av næringer. Grunnen kan være endrede rammebetingelser, endringer i arbeidskraftens sammensetning, brede teknologiendringer osv.

Det er vedvarende forskjell i produktivitetsutviklingen på primær-, industri- og handelsleddet, og flere studier har påvist og drøftet disse forskjellene. Det er sannsynlig at sammenhengene mellom næringer dreier seg om blant annet vertikale relasjoner. Primærprodusenter, matindustri og dagligvarehandel må «spille på lag»om produktiviteten skal øke for verdikjeden som helhet. Samtidig er flere analyser først og fremst opptatt av konflikt og makt i verdikjeden.

Denne artikkelen skal se nærmere på den relative produktivitetsveksten fordelt på de tre siste leddene i verdikjeden: engros- og detaljhandel med matvarer og matindustri. Vi ser etter forskjeller mellom industri- og handelsledd og om det kan være en sammenheng mellom endringen over tid. Artikkelen kan gjerne sees i sammenheng med to andre artikler om priser og marginer og struktur (Pettersen, 2020; Friberg, Pettersen, Steen \& Ulsaker, 2020; se hhv. kap 4 og 2).

For å gi et bakteppe før vi beregner egne mål, gir vi i neste del et bilde av hva vi vet og litt om usikkerheten i produktivitetsmåling på et noe mer 
aggregert nivå. Del 3 diskuterer sentrale begreper og utfordringer med produktivitetsmålinger, og spesifikt hva dette innebærer for den vertikale kjeden som utgjør norsk matsektor. Endelig presenterer fjerde del nye utregninger for produktivitetsutvikling, før vi oppsummerer med en diskusjon rundt egne funn og mulige veier fremover.

Artikkelen viser nye beregninger for arbeidsproduktivitetsvekst i dagligvarehandelen, og oppdaterer estimatene for matindustrien. Vi legger samtidig vekt på usikkerheten i produktivitetsberegningene. Et av formålene er å skissere steg for å styrke dokumentasjonen av produktivitetsutviklingen i matsektoren. Produktivitet dreier seg om endring i marginer. Det betyr at feil i prisstatistikk eller misvisende måling av arbeidskraftsforbruk lett kan gi feilaktige konklusjoner.

Analysen peker på svakheter med tallgrunnlag og aggregeringsnivået i offentlig statistikk, noe som påvirker både resultater og muligheten for analyser, men like fullt synes fire konklusjoner å utkrystallisere seg.

- Matsektoren, som norsk næringsliv ellers, opplever samlet en svekkelse av produktivitetsveksten for perioden 2008 til 2017 sammenlignet med foregående tiår. Men på lang sikt har næringsmiddelindustrien forbedret seg fra et lavt historisk nivå; der det for eksempel var negativ produktivitetsvekst på 1980-tallet, ligger nå årlig arbeidsproduktivitetsvekst på mellom to og tre prosent. Sjømatindustrien trekker opp matindustriens produktivitetsvekst. Lengre nede i den vertikale kjeden har dagligvarehandelen hatt en historisk produktivitetsvekst på mer enn $5 \%$ årlig i denne lange perioden frem til 2010, men opplever nå et kraftig fall i årlig produktivitetsvekst til 3,1\% etter 2010.

- Produktivitetsveksten har dermed vært høyere i dagligvarehandelen enn i næringsmiddelindustrien, men tallene ser ut til å konvergere i perioden etter 2010. Primærproduksjonen har også relativt sterk produktivitetsvekst, men igjen skiller sjømatsektoren seg ut. Akvakultur har et markert fall i produktivitetsvekst de seneste årene. Siden forskjellen mellom dagligvarehandelen og industrien samsvarer med forskjellen mellom industri og varehandel generelt, finnes neppe hovedforklaringen på forskjellene mellom industri og detaljledd spesifikt i matsektoren. 
- I dagligvarehandelen er det høyere produktivitetsvekst på detaljistleddet enn på engrosleddet. Forklaringen er knyttet til ulik prisutvikling på de to leddene. Samtidig er engros- og detaljhandel $\mathrm{i}$ stor grad vertikalt integrert, slik at prisdannelsen mellom de to leddene kan sees som resultat av intern styring i virksomheter med varierte former for vertikal integrasjon og kontroll, mer enn som et resultat av konkurranse og kjøper- eller selgermakt.

- Den fjerde observasjonen er at sjømatsektoren er i ferd med å få en avgjørende betydning for produktivitetsutviklingen for næringsmiddelindustrien og matsektoren som helhet. Produktivitetsutviklingen skiller seg så vidt mye mellom næringsmiddelindustri generelt og sjømat at man bør analysere disse separat. Det er videre stor forskjell på prisutviklingen for innsatsvarer og handelsvarer til norsk matindustri og dagligvarehandel sammenlignet med den samlede førstehåndseller engrosomsetningen av matvarer i Norge, inklusiv all sjømat.

Bakgrunnen for konklusjonene, begreper og regnemåter, gjennomgås og drøftes i resten av artikkelen.

\section{Arbeidsproduktivitet}

Presentasjonen starter med hovedtrekkene i produktivitetsutviklingen i primærnæring, industri og handel, før vi redegjør for usikkerheten i produktivitetstallene.

\section{Det store bildet}

Hovedtrekkene ved utviklingen i arbeidsproduktiviteten i markedsrettet fastlandsøkonomi, inkl. fiske og akvakultur, kan oppsummeres slik:

- Klart høyest produktivitetsvekst i primærnæringer de siste 20 år, og vesentlig høyere produktivitetsvekst i varehandel enn industri.

- Produktivitetsveksten er fallende for alle hovedsektorer: Snittet for de siste ti årene er lavere enn for tyveårsperioden under ett. 
- Tre enkeltsektorer har særlig sterkt fall i produktivitetsveksten: Akvakultur, fiske og fangst og agentur og engroshandel. Veksten i arbeidsproduktiviteten er relativt stabil for samlet detaljhandel og næringsmiddelindustri, samt industri totalt.

Figur 1 presenterer hovedtrekkene for de to siste tiårsperiodene frem til 2017. I denne delen av artikkelen må vi sammenligne næringsmiddelindustri med varehandel totalt. Skillet mellom dagligvarehandel og annen varehandel gjøres senere i artikkelen.

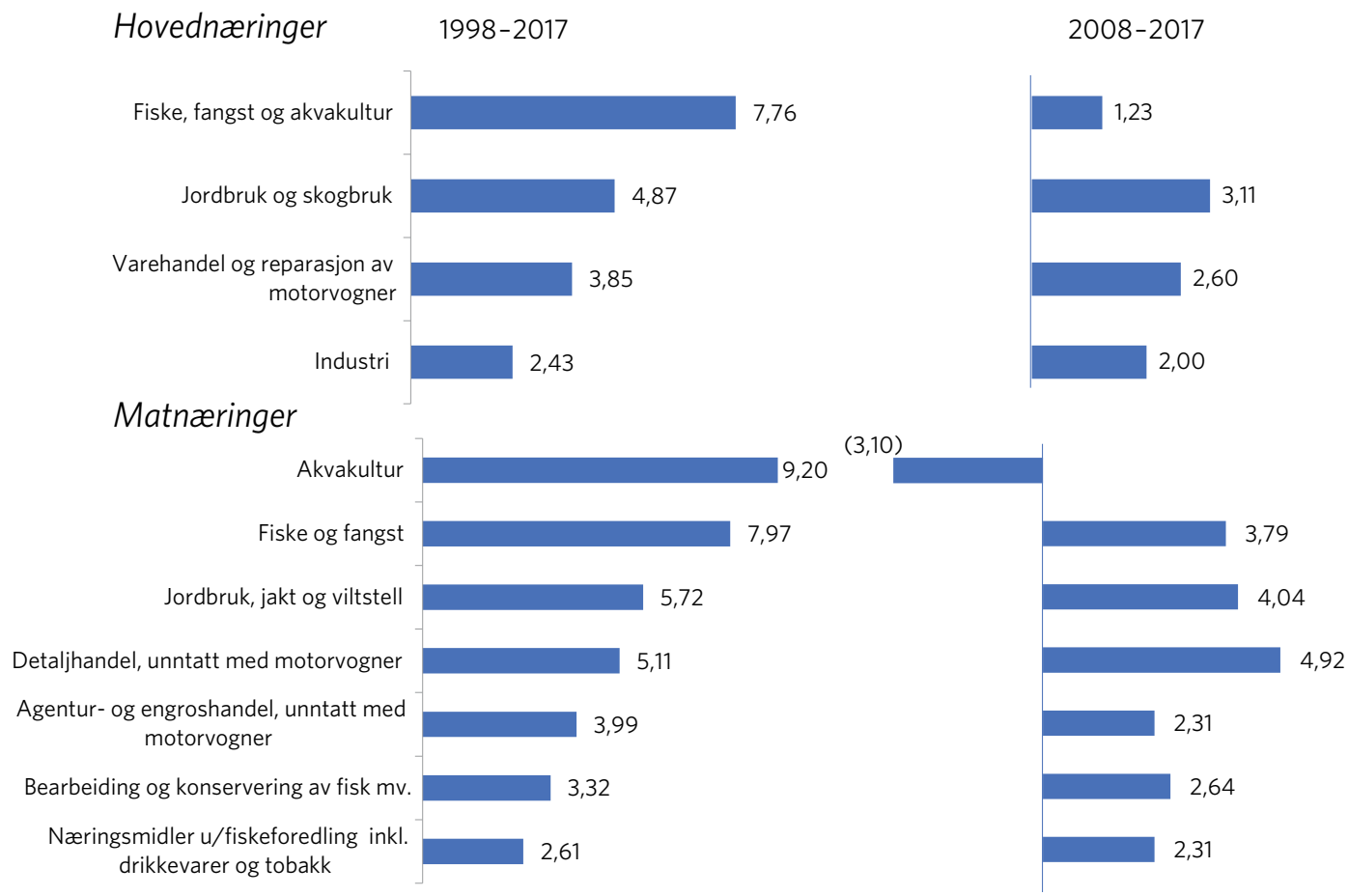

Figur 1 Årlig endring i arbeidsproduktivitet, primærnæringer og industri. Tall i prosent, snitt 1998-2017 og 2008-2017.

Kilde: SSB, nasjonalregnskap.

Bakgrunnsbildet med synkende produktivitetsvekst for hovednæringene er noe mer sammensatt når vi ser på produktivitetsveksten for enkeltsektorer innenfor matrelaterte næringer på primær-, industri- og handelsleddet (nederste del av figur 1). 
Tiltagende, relativ produktivitetsvekst i næringsmiddelindustrien har redusert forskjellene i produktivitetsvekst mellom varehandel totalt og næringsmiddelindustri over tid. Etter å ha ligget under vekstraten for industrien samlet, er produktivitetsveksten høyere i næringsmiddelindustrien enn i samlet industri. Forskjellen i produktivitetsvekst mellom næringsmiddelindustri og varehandel totalt er redusert det siste tiåret (figur 2).

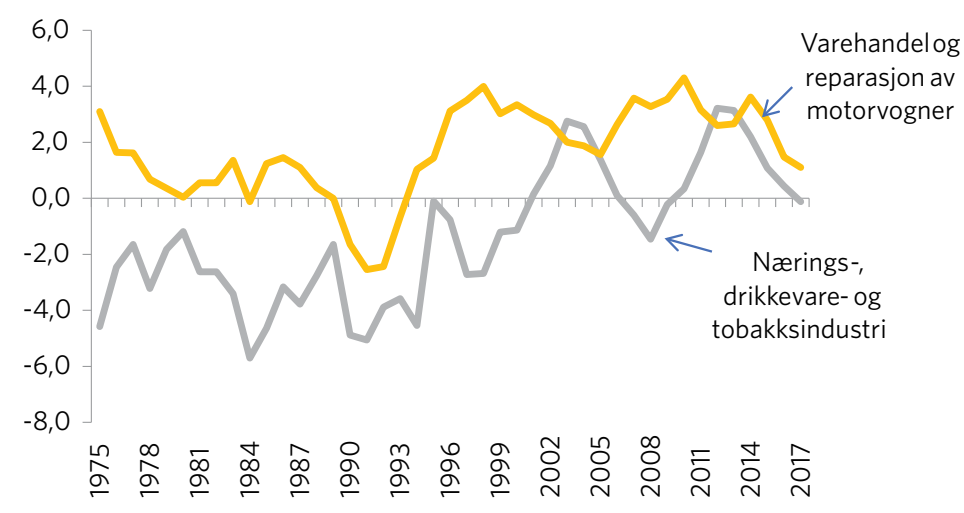

\begin{tabular}{lrrrrr} 
Samlet produktivitetsvekst i ulike peroder & $1971-81$ & $1981-91$ & $1991-2001$ & $2001-11$ & $2011-17$ \\
\hline Nærings-, drikkevare- og tobakksindustri & $6 \%$ & $-10 \%$ & $24 \%$ & $8 \%$ & $18 \%$ \\
Varehandel og reparasjon av motorvogner & $82 \%$ & $29 \%$ & $73 \%$ & $33 \%$ & $22 \%$ \\
\hline
\end{tabular}

Figur 2 Relativ arbeidsproduktivitetsvekst i næringsmiddelindustri og varehandel totalt. Prosentvise, årlige observasjoner, differanse til arbeidsproduktivitetsvekst for næringer totalt. 1975-2017. Alle observasjoner er femårs glidende gjennomsnitt. Kilde: SSB, nasjonalregnskap. Produksjon og inntekt etter næring, statistikkvariabel og år.

Produktivitetsveksten i matsektoren som helhet kan økes ved at enkeltnæringene innoverer og utnytter produksjonsressursene mer effektivt, men også ved at sektorer med høy produktivitetsvekst trekker ressurser fra sektorer med relativt lav produktivitetsvekst. Det gjør det interessant å se produktivitetsvekst og sysselsettingsvekst i sammenheng. Figur 3 viser arbeidsproduktivitetsvekst slik den måles i nasjonalregnskapet samt vekst i sysselsetting målt $i$ antall timeverk for matrelaterte næringer.

For tyveårsperioden under ett viser figuren en tendens til at sektorer med høy produktivitetsvekst øker sysselsettingen mest, eller reduserer sysselsettingen minst. Det er to naturlige unntak: jordbruk og fiske. Begge 
disse sektorene er begrenset enten av markedets størrelse, som følge av handelsbarrierer, eller av tilgang på fiskekvoter og råstoff. Samtidig utmerker de seg med høy produktivitetsvekst og nedgang i sysselsettingen.

I siste del av perioden, nederste del av figur 3, er utviklingen mindre systematisk. Akvakultur har fall i produktivitetsveksten og vekst i sysselsettingen målt i antall timeverk. Fiskeindustrien går fra negativ til positiv sysselsettingsvekst, fortsatt med relativt høy produktivitetsvekst. Næringsmiddelindustrien for øvrig, går motsatt vei, fra positiv til negativ sysselsettingsvekst med en svak nedgang i gjennomsnittlig årlig produktivitetsvekst.

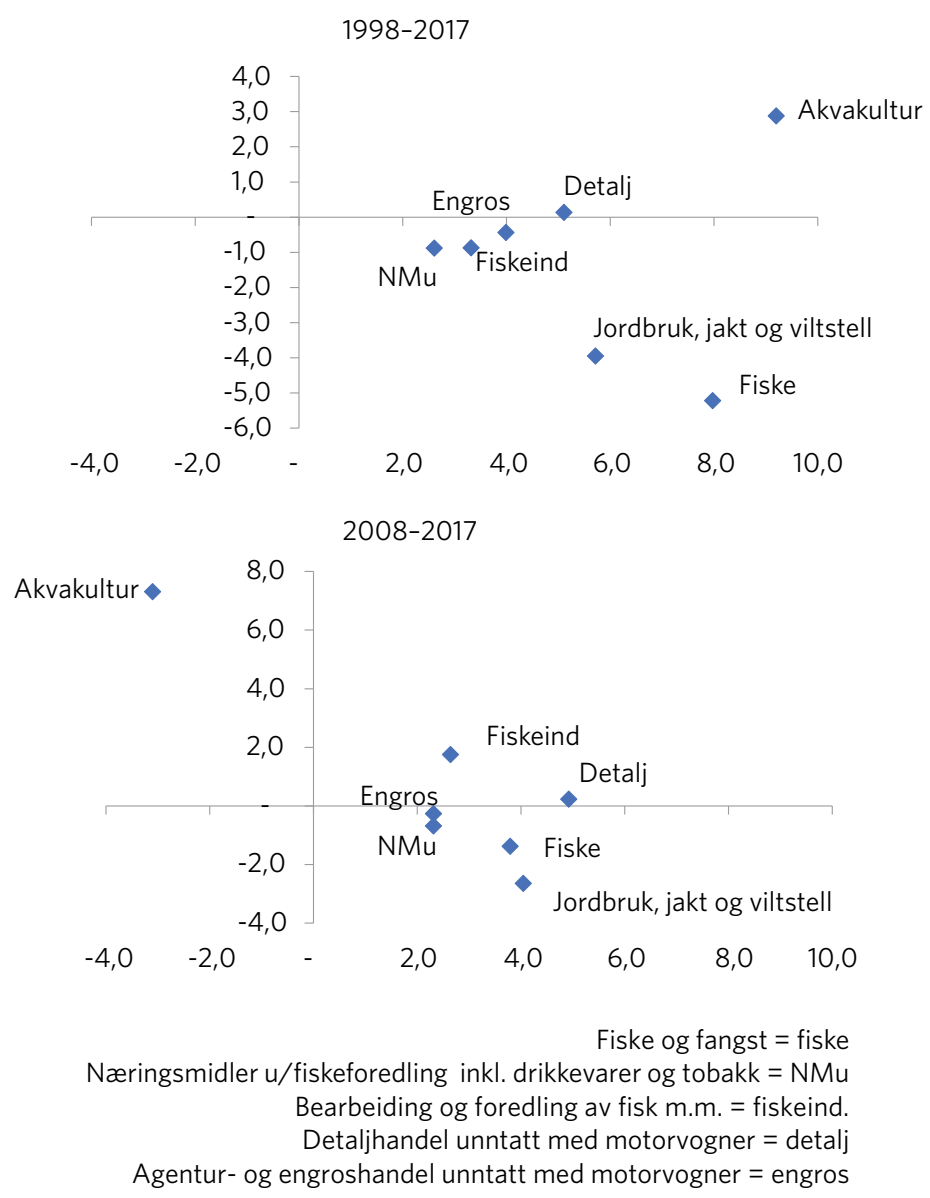

Figur 3 Vekst i timeverk (vertikal akse) og arbeidsproduktivitetsvekst (horisontal akse). 1998-2017 øverst, 2008-2017 nederst. Kilde: SSB, nasjonalregnskap. 
Varehandelen, spesielt i detaljhandelen, har relativt stabil, svak sysselsettingsvekst og høy, stabil produktivitetsvekst. Agentur- og engroshandelen har konsekvent nedgang i sysselsettingen og redusert produktivitetsvekst over tid.

Disse hovedtrekkene er også funnet i tidligere studier. Vagstad (2011) og Gabrielsen, Steen, Sørgard og Vagstad (2013) viser begge at norsk varehandel generelt og dagligvarehandelen spesielt hadde sterk målt produktivitetsvekst sammenlignet med matindustrien og industrien generelt, både i et langsiktig perspektiv og for det første tiåret etter 200o. Resultatet gjaldt både for arbeidsproduktivitet og såkalt multifaktorproduktivitet (MFP), som tar hensyn til kapitalinnsats.

\section{Litt om usikkerhet i eksisterende målinger}

Alle disse registrerte vekstratene for arbeidsproduktiviteten er basert på offisielle nasjonalregnskapstall, med ett unntak: For å kunne se på næring rettet mot norske verdikjeder er næringsmiddelindustri beregnet som næringsmiddel-, drikkevare- og tobakksindustri med en nedjustert andel sjømatindustri som tilsvarer andelen av sjømat i samlet matvarekonsum.

Stor variasjon fra år til år gjør at fallene i arbeidsproduktivitetsveksten bare i få tilfeller er statistisk signifikante. Sammenligning av tyveårsperioder viste kun én signifikant endring ved bruk av treårs gjennomsnittstall: økningen i vekstraten for produktiviteten i nærings-, drikkevare og tobakksindustrien (se forklaring i boks 1).

\section{Boks 1. Signifikante endringer i vekstrater}

Det er store svingninger mellom årlige observerte vekstrater for arbeidsproduktivitet. Svingningene er størst for relativt snevert definerte næringer, som akvakultur og sjømatindustri, og mindre for brede, som f.eks. samlet industri eller varehandel. For å redusere betydningen av mulige tilfeldige årlige svingninger, er signifikanstestene utført på treårs gjennomsnittstall. 
Det er ved oppdeling av den siste tyveårsperioden vi finner flere signifikante endringer. Tabellen nedenfor oppsummerer signifikanstester for forskjellene mellom de to siste tiårsperiodene med seks signifikante fall i vekstrater. Ved siden av det markerte fallet for akvakulturnæringen er reduksjonen i vekstraten for varehandelen, spesielt for agentur- og engroshandel, tydelig. Veksten for varehandelen, spesielt detaljhandelen, er imidlertid fortsatt relativt høy. Skiftet for varehandelen gir grunn til å forsøke å se nærmere på endringene i dagligvarehandelen atskilt fra øvrig varehandel.

Tabell 1 Tilfeller med signifikant endring i arbeidsproduktivitetens vekstrater basert på treårs glidende gjennomsnitt. Kilde: SSB, regnskapsstatistikk.

\begin{tabular}{|l|r|r|r|r|}
\hline & 1978-1997 & 1998-2007 & 2008-2017 & $\begin{array}{r}\text { Signifikans; endring } \\
\text { fra 1998-2007 til } \\
\text { 2008-2017 }\end{array}$ \\
\hline $\begin{array}{l}\text { Varehandel og reparasjon } \\
\text { av motorvogner }\end{array}$ & 3,8 & 5,1 & 2,6 & Under 5\% \\
\hline Akvakultur & 23,0 & 21,5 & $-3,1$ & Under 5\% \\
\hline $\begin{array}{l}\text { Agentur- og } \\
\text { engroshandel, unntatt } \\
\text { med motorvogner }\end{array}$ & 4,4 & 5,7 & 2,3 & Under 5\% \\
\hline $\begin{array}{l}\text { Detaljhandel, unntatt } \\
\text { med motorvogner }\end{array}$ & 5,0 & 5,3 & 4,9 & Under 5\% \\
\hline $\begin{array}{l}\text { Fiske, fangst og } \\
\text { akvakultur }\end{array}$ & 7,3 & 14,3 & 1,2 & Under 5\% \\
\hline Industri, totalt & 2,0 & 2,9 & 2,0 & Under 5\% \\
\hline $\begin{array}{l}\text { Bearbeiding og } \\
\text { konservering av fisk mv. }\end{array}$ & $-0,6$ & 4,0 & 2,6 & Under $10 \%$ \\
\hline
\end{tabular}

\section{Måling av produktivitet}

Nedenfor redegjør vi først for selve produktivitetsbegrepet, deretter bearbeidingsverdi og prisindekser som kan belyse prisene for selve bearbeidingsverdien. Til sist undersøker vi arbeidsinnsatsen.

\section{Arbeidsproduktivitet og produktivitetsvekst}

Arbeidsproduktivitetsvekst er vekst i bearbeidingsverdi justert for prisendringer dividert med vekst i arbeidsinnsats, dvs. produsert mengde pr. 
årsverk eller timeverk. Vi ser ikke på forskjeller i produktivitetsnivå, selv om både forskjeller i bearbeidingsverdi pr. timeverk og endring i vekstrater ble vist i Vagstad (2011) og i Gabrielsen et al. (2013). Sammenligning av nivå er mer usikkert jo mer ulike næringer er med hensyn til teknologi, kapitalinnsats osv. Endringer over tid er imidlertid mer sammenlignbart siden vi da ser på hvordan en næring med sin teknologi er i stand til å øke sin egen produktivitet. Her er vi opptatt av å belyse drivkreftene for produktivitetsvekst innenfor enkeltsektorer over tid, og da velger vi å sammenligne endringstall, heller enn nivå.

Bearbeidingsverdien er samlet ressurs til godtgjørelse av arbeidskraft og kapital i virksomhetene. Verdiene avhenger av behandling av f.eks. kapitalslit samt offentlige tilskudd og avgifter. I våre beregninger regnes bearbeidingsverdien som et bruttobegrep, altså før fradrag for kapitalslit. Vi kommer tilbake til avgifter og subsidier.

Produktiviteten regnes ut fra mengdetall. Vi skal se hvor mange enheter vi får igjen for bestemt mengde arbeidsinnsats, dvs. renset for inflasjon og andre, rene priseffekter. Økt markedsmakt, som gir seg utslag i økte salgspriser eller reduserte innkjøpspriser, skal altså ikke påvirke produktivitetsveksten, bare lønnsomheten. Om markedsmakt derimot resulterer i mer sløsing med fysiske ressurser, reduseres produktiviteten. I vår analyse vil det ikke være nivået av markedsmakt eller sløsing som påvirker tallene, men økende eller redusert sløsing over tid.

Mengdetall må beregnes fra verditall for sammensatt omsetning som prisjusteres med prisindekser for brede varegrupper. Vi finner da ikke nivåer av mengder, og heller ikke nivåer på produktivitet; kun endringer, dvs. vekstrater over tid. Veksten i arbeidsproduktivitet regnes som endring i bearbeidingsverdi per enhet arbeidskraft, justert for prisendringer. Prisjusteringen skjer ved at bearbeidingsverdier i løpende priser erstattes av differansen mellom prisjusterte tall for produksjonsverdi og prisjusterte verdier av forbruk av innkjøpte varer og tjenester. I nasjonalregnskapet oppgis en prisindeks for bearbeidingsverdien. Denne prisindeksen blir imidlertid ikke utledet fra prisobservasjoner direkte, men ved å sammenligne beregnet bearbeidingsverdi i løpende priser med den avledede bearbeidingsverdien etter prisjustering av produksjon og vareforbruk. 


\section{Bearbeidingsverdier}

Tekstboksen (boks 2) beskriver bearbeidingsverdiberegningen i nasjonalregnskapet. Ved omregning av bearbeidingsverdi i løpende priser til verdier i faste priser må bearbeidingsverdien i løpende priser justeres ved å prisjustere hvert element for seg - omsetning, kjøp av handelsvarer og forbruk av andre varer og tjenester - hvert element med ulike prisindekser.

Bearbeidingsverdiens andel av samlet omsetning viser hvor stor andel av omsetningen næringen bruker for å bearbeide innkjøpte varer og tjenester til salgbare produkter ved hjelp av virksomhetens arbeidskraft og kapital. Selv om ulike produksjoner og handelssektorer nødvendigvis må ha ulike teknologier og produksjonsforhold, kan sammenligning av bearbeidingsverdienes andeler gi en idé om hvilke sektorer som krever mest ressurser til interne bearbeidings- og varehåndteringsprosesser.

Sammenligning av handelssektorene tyder på at dagligvarehandel er relativt lite ressurskrevende. Figur 4 viser at andelen for bearbeidingsverdier er lavere i dagligvarehandel enn i annen handel med forbruksvarer. For hver krone omsatt i engroshandel med vanlige dagligvarer, dvs. engroshandel med bredt utvalg av nærings- og nytelsesmidler som dekker de store

Boks 2. Bearbeidingsverdi og bruttomarginer i nasjonalregnskap og regnskapsstatistikk

Bearbeidingsverdien (B) beregnes i offisiell statistikk ut fra produksjonsverdi $(\mathrm{P})$ minus forbruk av varer og tjenester (F). Produksjonsverdien er, grovt regnet, lik omsetning (O) minus innkjøp av handelsvarer $(\mathrm{H})$ justert for beholdningsendringer. Denne regnes netto for merverdiavgift og produktavgifter. $\mathrm{H}$ er innkjøpsverdi av varer som omsettes uten bearbeiding. I nasjonalregnskapet oppgis bare produksjonsverdi, ikke omsetning. Det gir stor forskjell i rapporteringen for varehandel og industri. I handelen er omsetning av handelsvarer hovedaktivitet, og bruttomarginen $(\mathrm{O} / \mathrm{H})$ en sentral styringsparameter. I industrien er omsetningen av handelsvarer normalt en mindre biaktivitet, mens $\mathrm{B} / \mathrm{F}$ blir en viktig styringsparameter. kjedene, blir under 6 prosent igjen til arbeidskraft og samlet kapital i engrosforetakene. Innkjøpte handelsvarer dekker 89,8 prosent av omsetningen, mot 78,6 prosent $\mathrm{i}$ annen engrosvirksomhet med næringsmidler, og 66,6 prosent for engroshandel med andre konsumvarer. For detaljhandel er forskjellene av samme karakter. Detaljhandel med bredt vareutvalg 
(supermarkedene) bruker 13,8 prosent til egen arbeidskraft og kapital, mens innkjøpte handelsvarer dekker 75,2 prosent av omsetningen. For annen detaljhandel enn med nærings- og nytelsesmidler, utgjør handelsvarene 62,9 prosent. Handelsforetakene «beholder» vel 20 prosent $(15,8+4,5$ til henholdsvis lønnskostnader og driftsresultat) til egen bearbeiding.

Engroshandel

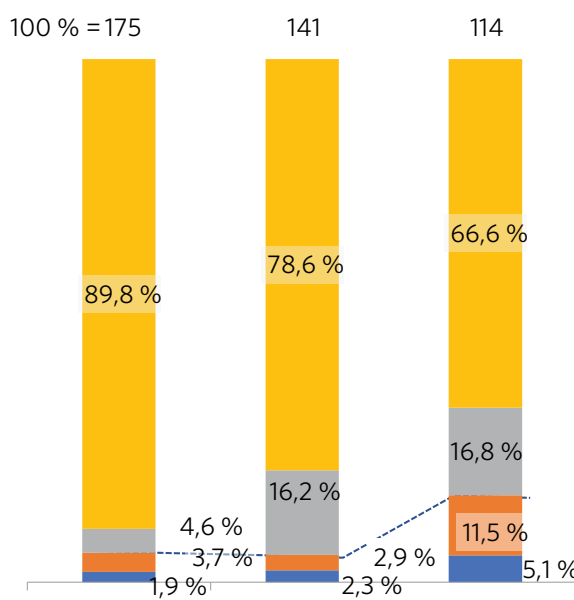

Bredt vareutvalg av nærings- og nytelsesmidler
Nærings-og Andre nytelsesmidler konsumvarer
Detaljhandel

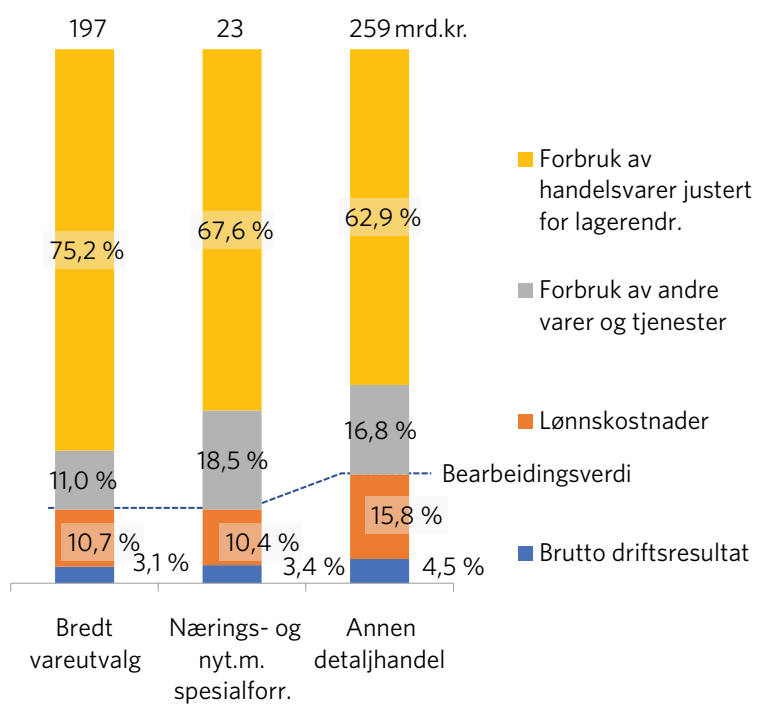

Figur 4 Bearbeidingsverdier i dagligvarehandel og handel totalt. Andeler av omsetning. Snitt 2015-2016. Kilde: SSB, strukturstatistikk, varehandel.

\section{Prisindekser}

Som nevnt tidligere, skal produktivitetsveksten renses for rene priseffekter, dvs. prisendringer som ikke skyldes endret produkt, kvalitet eller service. Skillet er krevende både for enkeltbedrifter som skal rapportere, og for utarbeidelse av statistikk. Prisjusteringen innebærer dermed stor usikkerhet for beregningen. Siden bearbeidingsverdien bare utgjør en liten del av total omsetning, kan valg av prisindeks eller små feil i prisindeksene ha stor betydning for beregnet bearbeidingsverdi i faste priser (von Brasch, 2015). Som vi skal se i de neste avsnittene, er den perioden vi primært studerer, 2007 til 2017, preget av betydelige forskjeller i prisutvikling på ulike ledd i verdikjeden. 
Prisindeksenes betydning ser vi ved å sammenligne prisindekser for bearbeidingsverdi (bruttoprodukt) for varehandel totalt og for matindustrien. Offisiell statistikk mangler prisindekser for enkeltsektorer innenfor varehandel. Vi skal senere analysere og illustrere prisutviklingen for bearbeidingsverdien i dagligvarehandelen nærmere.

Figur 5 viser bruttoproduktprisindeksene for varehandel totalt og for matindustrien. Bruttoprodukt er betegnelsen for bearbeidingsverdi i nasjonalregnskapet før fradrag for kapitalslit. Prisutviklingen har over tid vært mer gunstig for matindustriens bearbeiding enn for samlet varehandel. Som nevnt ovenfor er prisene for selve bearbeidingen (bruttoproduktprisene) avledet fra innkjøpsverdier, innkjøpspriser, omsetningsverdier og salgspriser. Bare for årene 2007-2012 finner vi omtrent samme bruttoproduktprisutvikling for de to sektorene. Gunstig utvikling i prisindeksen for bruttoproduktet i matindustrien tyder på sterkere prisvekst for omsatte produkter enn for innkjøpte råvarer og tjenester. Mens Vagstad (2011) åpner for at produktivitetsveksten i dagligvarehandelen kan henge sammen med gunstigere innkjøpspriser fra industrien, er det vanskelig å se at prisindeksen for bruttoproduktet til matindustrien tyder på en mindre gunstig prisutvikling på matindustriens omsetning enn på innkjøpte råvarer.

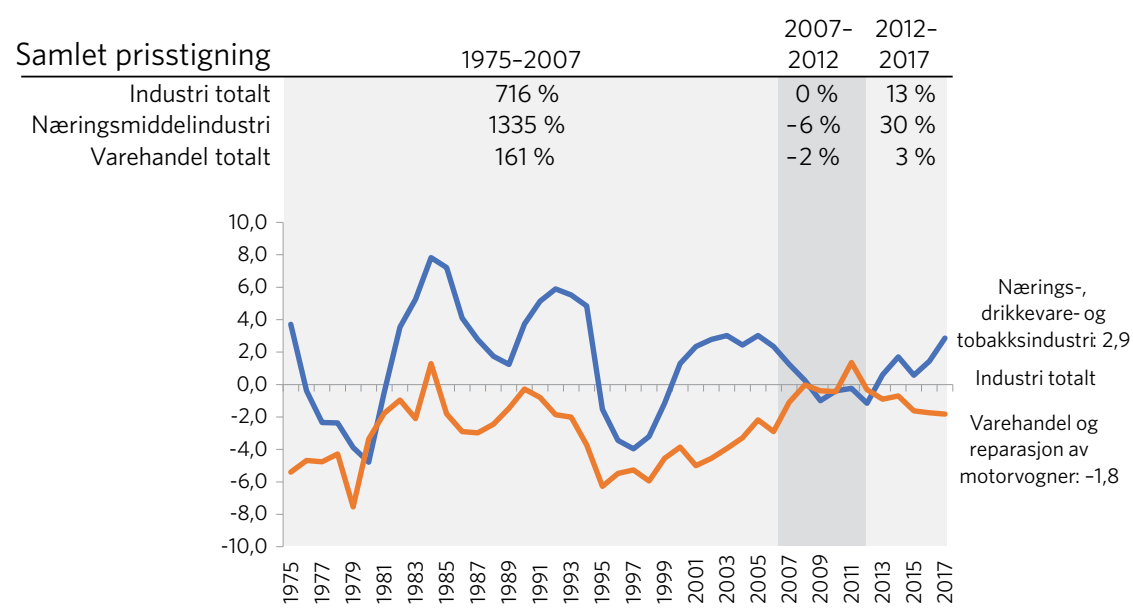

Figur 5 Utvikling i relative bruttoproduktpriser, varehandel totalt og matindustri.

Årlige relative prisendringer for bearbeidingsverdier. Prosent pr. år, femårs glidende gjennomsnitt. Differanse til prisutviklingen for industrien totalt. Kilde: SSB, nasjonalregnskap. Produksjon og inntekt, etter næring, statistikkvariabel og år. 


\section{Arbeidsinnsats}

Som mål på arbeidsinnsats bruker vi nasjonalregnskapstall for antall timeverk for summen av lønnstakere og selvstendige næringsdrivende og antall sysselsatte fra strukturstatistikken. Det er minst tre feilkilder.

For det første må timeverk for selvstendige næringsutøvere beregnes. Også for lønnstagere kan det være usikkerhet om timetallet, siden årsverket kan ha ulike timetall hos ulike arbeidsgivere. For det andre vil de fleste virksomheter ha noe innleie av arbeidskraft eller bruk av entrepriser som erstatter egne tilsatte. Pettersen og Romsaas (2019) viser f.eks. at andelen innleie i prosent samlede kostnader til arbeidskraft har økt kraftig i deler av både dagligvarehandel og matindustri. Det foretas, så langt vi forstår, ingen korreksjon i timeverkstallene for andelen innleid arbeidskraft.

Timeverk betraktes som homogen ressurs uavhengig av fagopplæring, utdanning, språklige ferdigheter osv. Endringer i sammensetningen av arbeidskraften over tid blir ikke hensyntatt $\mathrm{i}$ vår analyse, man kan ha vesentlige konsekvenser (von Brasch, Cappelen \& Iancu, 2018).

\section{Faktorer som skaper forskjeller i produktivitetsvekst}

Det finnes ingen enkle forklaringer til variasjoner i produktivitetsvekst over tid og mellom næringer. Studier på mikronivå viser gjerne større forskjeller i produktivitetsvekst mellom foretak innenfor enkeltnæringer enn vi finner når vi sammenligninger næringer (Syverson, 2011).

\section{Konkurranse}

Produktivitetskommisjonens første rapport pekte bl.a. på faktorer som bidrar til produktivitetsvekst, som å ta i bruk bedre teknologi og overflytting av ressurser fra lavproduktiv til høyproduktiv aktivitet (NOU 2015:1). Tradisjonell innovasjonsteori viser at konkurranse kan motivere virksomheter til å ta i bruk ny teknologi og annen form for innovasjon (Schumpeter, 1947/2011). En effekt er også såkalte overflyttingsgevinster som følge av at ressurser flyttes fra lavproduktive til høyproduktive aktiviteter, virksomheter og næringer.

Å ta i bruk ny teknologi blir satt i sammenheng med internasjonal orientering siden teknologiutvikling og nye forretningsmodeller, av gode 
grunner, har større sannsynlighet for å skje utenfor Norges grenser enn her hjemme. Åpenhet og importkonkurranse er egenskaper hvor matsektoren skiller seg fra annen norsk industri (Gaasland, 2020, se kap. 5). På den annen side kan det hevdes at det er tilstrekkelig at markedet for kunnskap og teknologi er det viktigste, og det er neppe vesentlige hindringer for import av teknologitjenester til noen del av norsk matsektor.

Sammenhengen er imidlertid ikke entydig. Produktivitetskommisjonen peker på at konkurranse også kan virke begrensende for innovasjon og dermed for produktivitetsvekst; en sammenheng beskrevet som den «omvendte U» (Aghion, Bloom, Blundell, Griffith \& Howitt, 2005). Økt konkurranse kan stimulere innovasjon inntil et visst nivå på konkurransen, for deretter å utarme innovasjonsevnen. Økt markedsmakt kan også gi $ø k t$ evne til å finansiere forskning og innovasjon, mens sterk markedsmakt kan svekke motivasjonen for innovasjon og lede til såkalt «X-inefficiency» (Leibenstein, 1978). Konkurransen kan ha ulik effekt avhengig av forskjeller i teknologi og skalaforhold. Institusjonelle rammebetingelser kan også ha betydning. Man kan f.eks. ikke utelukke en positiv sammenheng mellom etableringshindringer, innovasjonstakt og produktivitetsvekst. Schumpeter (1947/2011) illustrerer dette ved et enkelt poeng: Det gir lite mening å sammenligne en situasjon med høy grad av konkurranse med en med høy konsentrasjon og markedsmakt, fordi det er lite realistisk å anta at teknologi, kostnadsfunksjoner og etterspørselsforhold er like i de to situasjonene.

Det er heller ikke slik at produktivitetsvekst alltid er et gode (Tinbergen, 1952). Det kan være svakheter i arbeidsmarkedet, eller i samhandelen med andre land, som begrenser velferdseffekten. Arbeidsproduktiviteten kan også øke som følge av høyt forbruk av ressurser som virksomheten ikke betaler for, f.eks. miljøgoder som rent vann og luft. Avhengig av hvordan man definerer innsatsen av arbeidskraft, kan også overbelastning av arbeidstagere som fører til økt sykefravær eller mindre trygge arbeidsforhold, være skjulte bieffekter av høy produktivitetsvekt. Sammenligning av veksten i arbeidsproduktivitet over tid og mellom sektorer gir derfor først og fremst mening om man kan dokumentere om det samtidig er skjedd betydelige endringer i utnyttelsen av ressurser som ikke blir hensyntatt i beregningen, som kapital eller miljøressurser som det ikke betales for. 


\section{Vertikale relasjoner produktivitetsvekst gjennom koordinering og datadeling}

Produktivitetsvekst påvirkes av de vertikale relasjonene mellom bransjer og virksomheter. Det er grunn til å regne med en viss gjensidig avhengighet mellom produktivitetsveksten på ulike ledd i verdikjeden. Vertikal organisering og samhandling har vært en viktig kilde til den produktivitetsveksten som har preget handelsleddet siden 1980-tallet. Handels- og distribusjonsleddene med logistikkaktørene har stått sentralt i en utvikling som er forbundet med teorier og ledelsesfilosofier som Supply-Chain

\section{Boks 3. Vertikal koordinering - eksemplet NGFLYT}

Koordinasjonsverktøyet NGFLYT er NorgesGruppens system for automatisk etterfylling av varer, og ble innført i 1997. I 2017 hadde 79 prosent av butikkene til NorgesGruppen implementert NGFLYT, herav alle KIWI-butikker. Systemet består bl.a. av «planogramdesign» som viser hvor i butikken varene ligger, prognoser, bestillingsforslag, vareplassering og varekjøp. I en masteravhandling avlagt ved FOODNHH analyserer Aahjem og Andersen (2017) effektene av innføringen av NGFLYT for brødvarer.

De analyserer både effekten på mersalg og matsvinn i 15 KIWI-butikker i perioden 2015-2017, og sammenligner disse med en kontrollgruppe med 15 lignende KIWI-butikker som ikke har innført NGFLYT. De kan benytte såkalt «forskjell-iforskjell-analyse», der de kan sammenligne salg og svinn før vs. etter introduksjonen av NGFLYT («forskjell») og kontrollerer for felles trender mellom butikker som har og ikke har innført NGFLYT («-i-forskjell»).

De finner klare signifikante effekter på begge størrelser. Butikkene øker sitt salg etter innføring av koordineringsverktøyet, og de reduserer matsvinnet. Interessant nok finner de større økonomiske effekter for dagsferske produkt som utgjør en større andel salgsmessig, men prediksjonsmodellene for etterspørselen er trolig bedre for langtidsholdbart brød der relativ salgsandel øker mer.

De regner også på kostnadsreduksjonen i de lokale KIWI-butikkene, der de verdsetter kostnadene av spart tidsbruk hos lokale kjøpmenn som tidligere måtte både prognostisere og bestille neste dags brød. Når de tallfester totaleffekten av innføringen av NGFLYT på denne ene varegruppen snakker vi om et tresifret antall millioner per år. 
Management (SCM), Efficient Consumer Response (ECR) (King \& Phumpiu, 1996) og Lean Thinking (Womack, Jones \& Roos, 1990). Bak disse begrepene ligger informasjonsteknologi og endringer i næringsstruktur både vertikalt og horisontalt. Vertikal koordinering av varestrømmer, vareutvalg og markedsføring har fått stor konsekvens for innovasjon og produktivitet, og også reist nye problemstillinger for konkurransepolitikken (Gabrielsen et al., 2013).

En ukoordinert forsyningskjede skader både fleksibiliteten og øker kostnadene (reduserer effektiviteten) ved å gjøre det dyrere å tilby et gitt nivå av produkttilgjengelighet. Et eksempel er «bullwhip-effekten» (Chopra \& Meindl, 2016); unødige og sterkt svingende lagerbeholdninger jo lenger vekk fra konsumenten man beveger seg. Hvis salgsleddet vet mer om lokal etterspørsel enn produsenten, og disse leddene ikke deler data, oppstår nevnte effekt som en konsekvens av dårlig koordinasjon og kommunikasjon.

Bullwhip-effekten begrenses ved bruk av informasjonsteknologi som gir bedre vertikal koordinering ved bruk av åpne koordineringsverktøy på tvers av salgs- og forsyningsledd. Dette kan dermed øke både fleksibilitet og effektivitet. Ved å analysere historiske data, samt hele tiden kunne forbedre og oppdatere prognosene for hver butikk, kan man få økt presisjon på det kvantum som leveres (økt fleksibilitet). Samtidig vil informasjonskoordineringen skape bedre og mer forutsigbare vilkår for produsentene, ettersom de nå på en bedre måte kan forutse det forventede bestillingskvantumet (økt effektivitet). Alle dagligvareaktører driver omfattende koordinering mot leverandører. Det kan være grunn til å se f.eks. Rema 10oos «Bestevenn»-satsing som et forsøk på å styrke koordineringen, selv om flere kommentatorer fremhever selve leverandørbetingelsene. NorgesGruppens system NGFLYT er et eksempel som har vært studert i mastergradsoppgaver (se boks 3). I dag er det meste av dagligvarelogistikken kontrollert av handelsleddet. På leverandørsiden er Tines Phønix-prosjekt fra 2016 et eksempel på tilsvarende ambisjoner i en leverandørkontrollert forsyningskjede.

Phønix prosjektet illustrerer at det er store og signifikante produktivitetseffekter som kan oppnås gjennom å dele data mellom handels- og industriledd ${ }^{1}$. Ofte vil en slik deling forutsette vertikal integrasjon, og

1 Se for eksempel beskrivelse i Logistikk og Ledelse: https://www.tungt.no/logistikk/kunstena-distribuere-2031679 
i så måte illustrerer dette sammenfallet mellom bedre vertikal koordinering, sterk produktivitetsvekst og omfattende vertikal integrering av grossist- og detaljistledd. Videre integrasjon mot leverandørleddet har også bidratt. NorgesGruppen fikk f.eks. mulighet til å implementere NGFLYT for bakervarer da de integrerte vertikalt med brødleverandøren Bakehuset (Aahjem \& Andersen, 2017). Fra en situasjon der den lokale kjøpmannen bestilte antall brød for levering neste dag, overtok statistisk baserte prediksjonsmodeller jobben.

Vertikal integrasjon åpner en del konkurransemessige utfordringer generelt, som bl.a. er forklart i Tirole (2014) og viet stor oppmerksomhet i Matkjedeutvalget (NOU 2011:44). En slik utfordring er spørsmålet om hvorvidt vertikal integrasjon virker ekskluderende ved å stenge konkurrenter ute. I så fall kan den virke begrensende på konkurransen og produktivitetsveksten. Diskusjonen gjelder spesielt om man skal tillate den typen datadeling som er nødvendig for effektivt koordinert vareflyt også mellom uavhengige bedrifter, enten direkte, eller via tredjeaktør. Deling av informasjon vertikalt kan øke kaken for alle, inkludert forbrukerne og i så måte er det en potensiell vinn-vinn situasjon, men det kan også oppstå ekskluderingseffekter og konkurransebegrensende atferd. Tar vi i tillegg inn over oss den hurtige utviklingen vi har sett de siste årene $i$ maskinlæring og kunstig intelligens, øker potensialet for økt produktivitetsvekst trolig ytterligere gjennom datadeling vertikalt.

Som nevnt mener Vagstad (2011) at lavere innsatsfaktorpriser ikke kan utelukkes som forklaring til økt produktivitet på handelsleddet, men at $ø$ kte forbrukerpriser vanskelig kan være en forklaring. Det åpner for forklaringer som dreier seg om mulige endringer i forhandlingsstyrke mellom industri og dagligvarehandel, til gunst for dagligvarehandelen.

\section{Produktivitetsvekst gjennom bruk av ny teknologi}

På alle ledd i kjeden innføres det ny teknologi som effektiviserer driften, f.eks. robotisering og annen automasjon i industrien. I distribusjonen er nye lagerløsninger med bruk av robotteknologi, bedre pakkeløsninger og skalafordeler gjennom større sentrallagre årsaker til produktivitetsvekst. For kjedeleddet har vi også sett at teknologien gir nye muligheter. Helt tilbake til overgangen fra kjøpmannsdiskbutikker til selvbetjening har 


\section{Boks 4. Sevbetjente kasser - eksempel fra Meny}

Henrik Nøkleby og Christian Søreng analyserer i en masteravhandling på NHH forskningsprosjektet FOOD (2019) produktivitetseffekten av innføring av selvbetjente kasser i kassepunktet i Meny-butikker. De benytter tre år med kvitteringsdata fra ni Meny-butikker på Østlandet. Produktiviteten til kassepunktet måles ved å se på butikkenes omsetning relativt til tiden de ansatte er i kassene. Kassepunktet defineres som stedet hvor kundene registrerer og betaler varer, og kan bestå av betjente kasser, selvbetjente kasser eller en kombinasjon. Det er naturlig å anta at selvbetjente kasser reduserer behovet for ansatte i de betjente kassene, men samtidig oppstår det et behov for arbeidskraft i de selvbetjente kassene. Etter innføringen blir dermed tiden til de ansatte delt mellom de to kassetypene, og kassetiden blir da summen av tidsbruken i de betjente og i de selvbetjente kassene. Nøkleby og Søreng ser dermed på nettoeffekten på produktiviteten i kassepunktet. Den gjennomsnittlige innføringseffekten estimeres, men de ser også på effekten av ulik omsetningsandel gjennom de selvbetjente kassene og ulike andeler selvbetjente kasser. De utarbeidet fire scenarioer for ansattes tidsbruk i de selvbetjente kassene, og i det antatt mest virkelighetsnære finner de at innføringen av selvbetjente kasser i gjennomsnitt øker produktiviteten i kassepunktet med 5-15\%, alt annet likt. Videre finner de en produktivitetsforbedring per prosentpoengs økning i omsetningsandelen gjennom de selvbetjente kassene. Endelig finner de at en økning i andelen selvbetjente kasser forbedrer produktiviteten i kassepunktet. I et ekstremscenario der de selvbetjente kassene krever en ansatt til stede hele åpningstiden, vil selvbetjente kasser imidlertid ha en negativ effekt på produktiviteten i kassepunktet. De finner ingen bevis for at innføringen av selvbetjente kasser reduserer totalomsetningen.

kjedene tatt i bruk mer effektive teknologier. I nyere tid er for eksempel digitaliseringen av prislappene i butikkene en svært arbeidsreduserende teknologi. Nå ser vi at også kassepunktet i butikkene er i endring. Coop har gått så langt at de har introdusert sin første kasseløse butikk, og var først ute med selvscanning av varer i butikk. De andre aktørene er også i ferd med å innføre nye kassepunkt. I særdeleshet ser vi at man innfører selvbetjente kasser i flere og flere butikker. Gitt at de nye kassene også krever tilsyn i form av hjelp og kontroller, er det ikke opplagt hvor store 
produktivitetseffekter man har av slike systemer. I en ny masteroppgave fra FOOD-prosjektet analyserer Nøkleby og Søreng (2019) innføring av selvbetjente kasser hos Meny (se boks 4 ovenfor). I det de mener er det mest sannsynlige scenarioet, finner de signifikante og klare effekter av innføringen, der nettoeffekten av innføringen gir en reduksjon i bruken av arbeidstid til betjening av alle kasser i butikkene. De finner heller ikke tegn på at omsetningen reduseres av innføringen.

\section{Kapitalinnsats og produktkvalitet}

Produktive investeringer, uten tilsvarende økt sysselsetting, øker bearbeidingsverdien, og dermed den målte produktiviteten til arbeidskraften. Det betyr imidlertid ikke at samlet effektivitet, eller lønnsomheten, øker. For å kunne vurdere endring i samlet effektivitet i utnyttelsen av produksjonsressurser, kapital og arbeidskraft, er det nødvendig å måle vekst i total faktorproduktivitet, dvs. bidraget til økt verdiskaping fra annet enn innsats av ressurser utenfra. En klassisk artikkel som gjør nettopp dette for dagligvaresektoren i USA, fant at dagligvaresektoren på 1970-tallet hadde relativt lav produktivitetsvekst sammenlignet med økonomien for øvrig (Ratchford \& Brown, 1985). I Norge viste SSB (2012) både vekst i arbeidsproduktivitet og total faktorproduktivitet (TFP) fra 1970-tallet til 2011. Studien har en grov inndeling av norsk næringsliv i fire sektorer, hvorav varehandel inngår i privat tjenesteyting og matindustri er en del av industrien. For de to siste tiårsperiodene viser studien høyest produktivitetsvekst for privat tjenesteyting, etter begge produktivitetsmålene. Veksten i arbeidsproduktiviteten ligger o,6 til o,8 prosentpoeng høyere enn TFP for privat tjenesteyting, mens de to ligger på samme nivå for industrien.

Selv om Norge har knapphet på arbeidskraft og et høyt lønnsnivå sammenlignet med andre land, er det nødvendig å unngå ensidig vekt på arbeidsproduktivitet. Her tar vi hensyn til kapitalinnsatsen ved å se på bruttoinvesteringene. Figur 6 viser investeringene i verdikjeden for matvarer. Matindustrien har hatt om lag dobbelt så høyt investeringsnivå som dagligvarehandelen regnet i forhold til antall årsverk, lønnskostnader og bearbeidingsverdi. Høyere investeringer pr. sysselsatt bør isolert sett, om kapitalslitet er omtrent likt, bidra til høyere produktivitetsvekst $i$ industrien 
enn i varehandelen. Forskjellen i investeringsnivåer forsterker altså de produktivitetsforskjellene som er antydet fra oversikten ovenfor, dvs. høyere produktivitetsvekst i handel enn i industri. Samtidig utgjør investeringene en begrenset andel av lønnskostnadene, noe som tilsier at arbeidskraftens produktivitetsvekst er dominerende for total produktivitetsvekst.

\section{Pr. årsverk (1000 kr)}

\section{Nærings-, drikkevare- og tobakksindustri}

Engroshandel med næringsog nytelsesmidler

Sum engros og detalj med nærings- og...

Butikkhandel med bredt vareutvalg

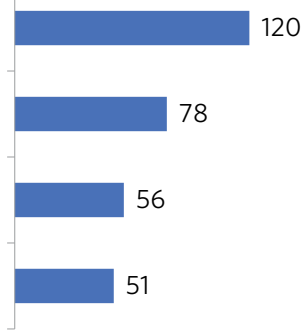

$\%$ av bearb. verd

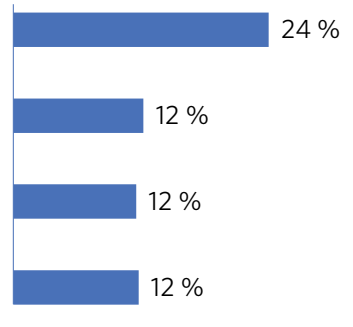

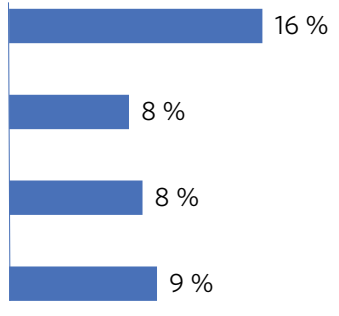

Figur 6 Bruttoinvesteringer pr. årsverk, i prosent av lønnskostnader og bearbeidingsverdi. Årsgjennomsnitt for perioden 2007-2017. Kilde: SSB, strukturstatistikk.

Vi finner det samme mønsteret når det gjelder vekstratene for bruttoinvesteringer på industri- og handelsleddet for matvarer. Industrileddet har hatt en nominell vekst i bruttoinvesteringer fra 2008 til 2017 på rundt fem prosent, engrosleddet om lag to prosent, og detaljistleddet rundt en prosent årlig (figur 7).
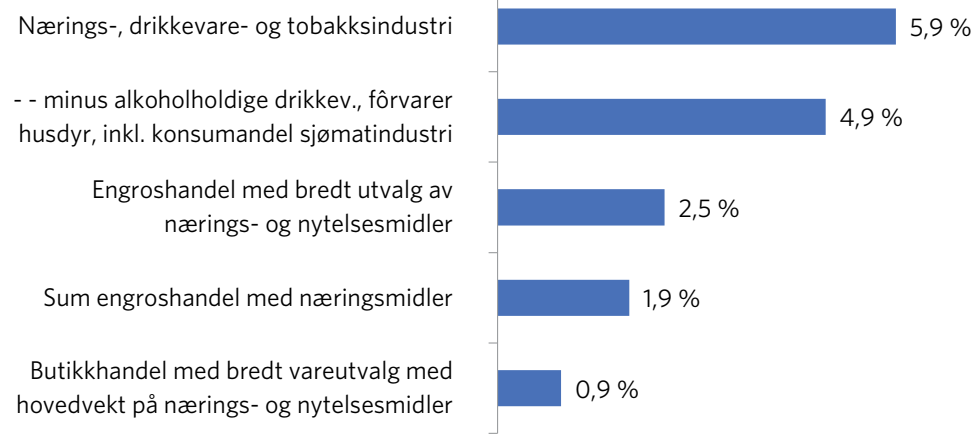

Figur 7 Vekst i bruttoinvesteringer over tid. Næringsmiddelindustri, engroshandel og detaljhandel med matvarer. Utvalgte sektorer. Årlige vekstrater i prosent fra snitt 2007-2008 til snitt 2016-2017. Kilde: SSB, strukturstatistikk. 
I tillegg til kapitalinnsatsen (investeringene) kan arbeidsproduktivitetsvekst også påvirkes av andre faktorer. Eksempler på slike kan være' produktforbedring, $ø$ kt butikktetthet, utvidede åpningstider, mer service til forbrukere og forhandlere eller flere tjenester til leverandører. Det er imidlertid usikkert om slike kvalitetsforbedringer vil gi seg utslag i bearbeidingsverdiene etter justering for prisendringer. Kvalitetsforbedringer i selve varetilbudet som gir prisøkninger må registreres som priser på nye produkter, om ikke også disse prisøkningen skal elimineres gjennom prisjusteringen. Det er derfor lett å tenke seg både kvalitetsforbedringer som ikke gir utslag i realpriser, og verdiøkende tjenester som ikke blir inkludert i produktivitetsveksten.

\section{Konjunkturer}

Over tid vil produktivitetsveksten sannsynligvis variere med konjunktursituasjonen. Nedgang i økonomisk aktivitet vil gjerne redusere kapasitetsutnyttelsen. Redusert kapasitetsutnyttelse vil si redusert bearbeidingsverdi sammenlignet med innsats av produksjonsfaktorer. Av denne grunn er analysen av produktivitetsutviklingen i norsk økonomi (SSB, 2012) basert på endringer mellom bunnen av konjunktursykluser. I den grad konjunkturutviklingen er ulik for ulike sektorer, vil konjunkturforløpet påvirke relativ produktivitetsvekst i ulike sektorer. ${ }^{2}$

\section{Sektor- og bransjeinndeling samt bransjeglidning}

Her vil vi studere vekstrater for arbeidsproduktivitet for de leddene i verdikjeden som bidrar til omsetning i supermarkedkjedene, dvs. detaljhandel og engroshandel med brede utvalg dominert av næringsmidler, inklusive engroshandel med frukt og grønt rettet mot supermarkedene, samt dagligvarehandelens leverandørindustri.

Innholdet i enkeltbransjene kan ikke bli helt konsistent gjennom verdikjeden og over tid; bl.a. fordi arbeidsdelingen mellom ulike ledd i verdikjeden er i endring. Et eksempel er overføringen av distribusjonstjenester fra leverandørene til grossistene (Oslo Economics/Oeconomica,

2 Gabrielsen et al. (2013) løste dette ved å benytte økonometriske modeller og kontrollere for BNP i sine sammenligninger mellom sektorer. 
2017), som overfører både bearbeidingsverdi og sysselsetting mellom leddene. Etablering av kjedenes egne merkevarer (Pettersen, 2013) og markedsføringssamarbeid mellom dagligvareledd og industri (NOU 2011:4; Pettersen, Dombu, Hegrenes \& Sørbye, 2015), har effekter på fordeling av verdiskaping og ressursinnsats.

For grossistleddet skiller ikke statistikken mellom foretak som først og fremst driver import- eller eksportvirksomhet og grossister som ligger innenfor de tre dominerende dagligvarekjedene. Det er også utfordringer på industrileddet. Vi må eksempelvis korrigere for andelen sjømatindustri for å gjenspeile den verdikjeden som retter seg mot norsk forbruk.

Bransjeglidningen betyr at mat og dagligvarehandelens husholdningsartikler omsettes gjennom mange ulike kanaler og bransjer som møbelutsalg, hagesentra, kiosker, bensinstasjoner og detaljistutsalg med brede vareutvalg som er dominert av andre varer enn matvarer, som f.eks. Europris. Varegrupper som tradisjonelt kun var solgt gjennom dagligvarehandel, selges nå i disse andre kjedene. Kanskje ser vi dette spesielt tydelig gjennom fremveksten av kjeden Normal, som har spist av dagligvarens omsetning innenfor vaskemidler og kroppshygiene. ${ }^{3}$ Omsetningen utenfor dagligvarehandelen er dermed økende. Analyser som vår, favner ikke økende gjennom alternative kanaler med mindre vekt på matvarer. Vi tar heller ikke hensyn til at dagligvarehandel i supermarkeder inkluderer varer som ikke kommer fra næringsmiddel- eller matindustrien.

Det er heller ikke mulig å avgrense verdikjedene presist. Dagligvarehandelen kjøper, som nevnt, fra andre leverandører enn næringsmiddelog drikkevareindustri. Matindustrien har andre, store kundegrupper enn dagligvarehandel. Grossistene har også andre kunder enn supermarkedene, og det er i praksis umulig å skille produktiviteten i én del av vareutvalget fra produktiviteten i andre deler. Bransjeinndelingen gir grunn til forsiktighet i bruken av resultatene for analyse av relasjoner i verdikjeden for matvarer.

3 I en masteroppgave på FOOD-prosjektet analyserer Eide og Syverinsen (2019) hvordan Normaletableringer i perioden 2016-2019 påvirket omsetningen i nærliggende Meny-butikker. De finner dels klare indikasjoner på at Meny sitt salg ble negativt påvirket, og dels at etableringen førte til reduserte priser i overlappende varesegment. 


\section{Beregnet produktivitetsvekst i dagligvarehandel og matindustri}

Beregningen av produktivitetsveksten i dagligvarehandelen dreier seg om tre hovedutfordringer for to sektorer: identifikasjon av egnede prisserier for omregning fra løpende verdier til mengdeindekser, beregning av bearbeidingsverdier og avgrensning av de to sektorene engroshandel og detaljhandel med dagligvarer.

\section{Prisindekser for engroshandel med dagligvarer}

Bearbeidingsverdi i faste priser beregnes ved å omregne både omsetning og forbruk av varer og tjenester til verdier i faste priser. Vedlegg 2 presenterer syv eksempler på prisindekser som er vurdert.

Statistikken viser stor forskjell i vekst i engrospriser, førstehånds- eller produsentpriser og forbrukerpriser. Forskjellene har betydning for prisjusteringen av bearbeidingsverdier. Matpriser på engros-, produsent- og førstehåndsledd har alle steget vesentlig mer enn konsumprisindeksen for matvarer. På 16 år har engrosprisene og førstehåndspriser for matvarer, ifølge offisiell statistikk, økt henholdsvis 51 prosent og 32 prosent mer enn konsumprisindeksen for matvarer. Det er store forskjeller i prisindekser for mellomleddene. Det har liten betydning om vi ser på matvarepriser med eller uten drikkevarer og tobakk (se figur 8). 


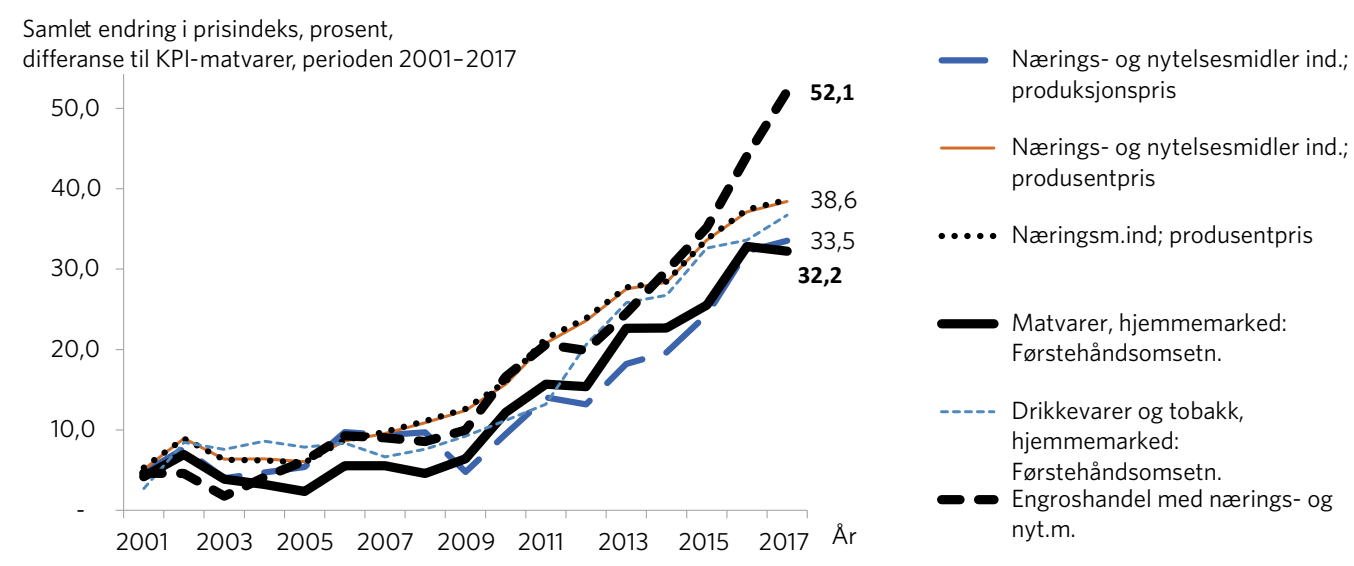

Figur 8 Seks matprisindekser for innkjøp av handelsvarer til engrosleddet. Sammenligning av utvikling over tid. Differanse til konsumprisindeks for matvarer. Prisindeks, $2000=100$, differanse til KPI-matvarer, perioden 2000-2018. Kilde: SSB, nasjonalregnskap og prisindekser.

Fire relevante prisindekser for engrosleddets kjøp av handelsvarer og for næringsmiddelindustriens utsalgspriser ligger innenfor en differanse i samlet prisstigning relativt til konsumprisindeksen for matvarer på 6,4 prosentpoeng over en periode på 16 år (jf. figur 8). Sammenlignet med utviklingen i bearbeidingsverdi pr. sysselsatt, er forskjellen mellom disse indeksene begrenset.

Det er imidlertid stort sprik mellom prisvekst for engrosleddets salgsog innkjøpsside. Prisindeksen for engroshandel med nærings- og nytelsesmidler har steget 13,5 prosentpoeng mer enn næringsmiddelindustriens produsentpris. Bruker vi denne prisindeksen for engroshandelens omsetning, får vi sterk vekst i avledet prisindeks for engroshandelens bearbeidingsverdi. Det er grunn til å regne med at engrosprisindeksen for sjømatprodukter, med sterk variasjon i prisene på eksportert laks, og det at frukt og grønt i liten grad omsettes til handelsleddene som industriprodukter, har betydning. Videre er en viktig del av innkjøpene til engroshandel med dagligvarer andre varer enn matvarer.

Konsekvenser av justeringer for disse faktorene innenfor den perioden vi ser på, 2007-2017, er begrensede (tabell 2). For det første får vi ingen nedgang i prisstigningen ved å ekskludere eksporten av næringsmidler 
fra industrien, dvs. at vi i praksis primært tar bort effekten av engroshandelens eksport av sjømat. Men registrert prisvekst øker mer markant når vi justerer prisindeksen med en forutsetning om at 90 prosent av frukt og grønt kjøpes inn til engrosleddet fra førstehånds omsetningsledd, dvs. fra importør eller direkte fra primærprodusent, og ikke via industrien. 90 prosent er her et skjønnsmessig anslag, og skal gjenspeile at pakkerier for frukt og grønt ikke regnes som industri, men som del av primærproduksjonen.

For å få et anslag for samlet innkjøp av både handelsvarer og forbruksvarer til engrosleddet, er siste justering en inkludering av kjøp av varer og tjenester utenom handelsvarer til norsk engroshandel generelt. Andelen på 15 prosent er anslått ut fra strukturstatistikkens andel handelsvarer av totale kjøp av varer og tjenester.

Tabell 2 Prisindekser for omsetning mellom leverandørledd og dagligvarehandelens engrosledd, årlig prosentvis prisendring, gjennomsnitt for 2007-2017. Endringene fra øverst til nederst i tabellen er kumulative, dvs. de er justeringer av anslagene i linjen ovenfor.

\begin{tabular}{|l|r|}
\hline Sektor & $\begin{array}{r}\text { Årlig } \\
\text { prisvekst }\end{array}$ \\
\hline $\begin{array}{l}\text { Næringsmidler, alkoholfrie drikkevarer og tobakk. Produsentpris. Hjemme- og } \\
\text { eksportmarked i alt }\end{array}$ & $4,1 \%$ \\
\hline Kun hjemmemarked & $4,2 \%$ \\
\hline $\begin{array}{l}\text { Erstatter produsentpris frukt og grønt med 90 \% prisindeks for } \\
\text { førstehåndsomsetning frukt og grønt. }\end{array}$ & $4,5 \%$ \\
\hline $\begin{array}{l}\text { Korrigerer for andelen ikke handelsvarer i totalt kjøp av varer og tjenester } \\
\text { - beregner prisindeks for engrosleddets samlede kjøp av varer og tjenester, } \\
\text { handelsvarer og forbruksvarer og -tjenester }\end{array}$ & $4,4 \%$ \\
\hline
\end{tabular}

Med innkjøpspriser som stiger mer enn fire prosent $\mathrm{i}$ året for perioden 2007-2017, er innkjøpsprisene i seg selv en kilde til lav prisvekst for engroshandelens bearbeidingsverdi. Som vi så av figur 5 er imidlertid stigningen i engrosprisindeksen for nærings- og nytelsesmidler høyere enn de prisindeksene som er vist i tabell 2.

Figur 9 gir en mer detaljert beskrivelse av engrosprisutviklingen i SSBs prisstatistikk. Sammenligningen av utviklingen i engrosprisindekser med konsumprisindeks viser store forskjeller. Engrospriser for nærings- og 
nytelsesmidler har hatt sterkere prisvekst enn andre konsumvarer som inngår i dagligvaresortimentet, og, som nevnt, betydelig sterkere enn for konsumpris for mat. Forskjellen mellom engrospris nærings- og nytelsesmidler og KPI for matvarer er 45,9 prosent akkumulert fra 2000 til 2018. Figuren viser også en konstruert engrosprisindeks for dagligvarer som er satt sammen av engroshandel med nærings- og nytelsesmiddel (84\%) og engroshandel med husholdsvarer og varer til personlig bruk (16\%) som er skjønnsmessig anslått andel andre varer enn matvarer i omsetningen. Denne indeksen ligger i 2018 nær engrosprisindeksen for total engroshandel, men 11,1 prosentpoeng lavere enn engroshandel for nærings- og nytelsesmidler. Andelen av husholdningsvarer og varer til personlig forbruk som regnes inn i dagligvaresortimentet har altså stor betydning for prisindeksen (se figur 9). Andre husholdningsvarer enn matvarer har vesentlig lavere prisvekst på engrosleddet. Det kan både ha sin bakgrunn i prisutviklingen på primær- og industriledd sammenlignet med importerte dagligvarer, og i struktur og atferd på engrosleddet for matvarer sammenlignet med andre dagligvarer.

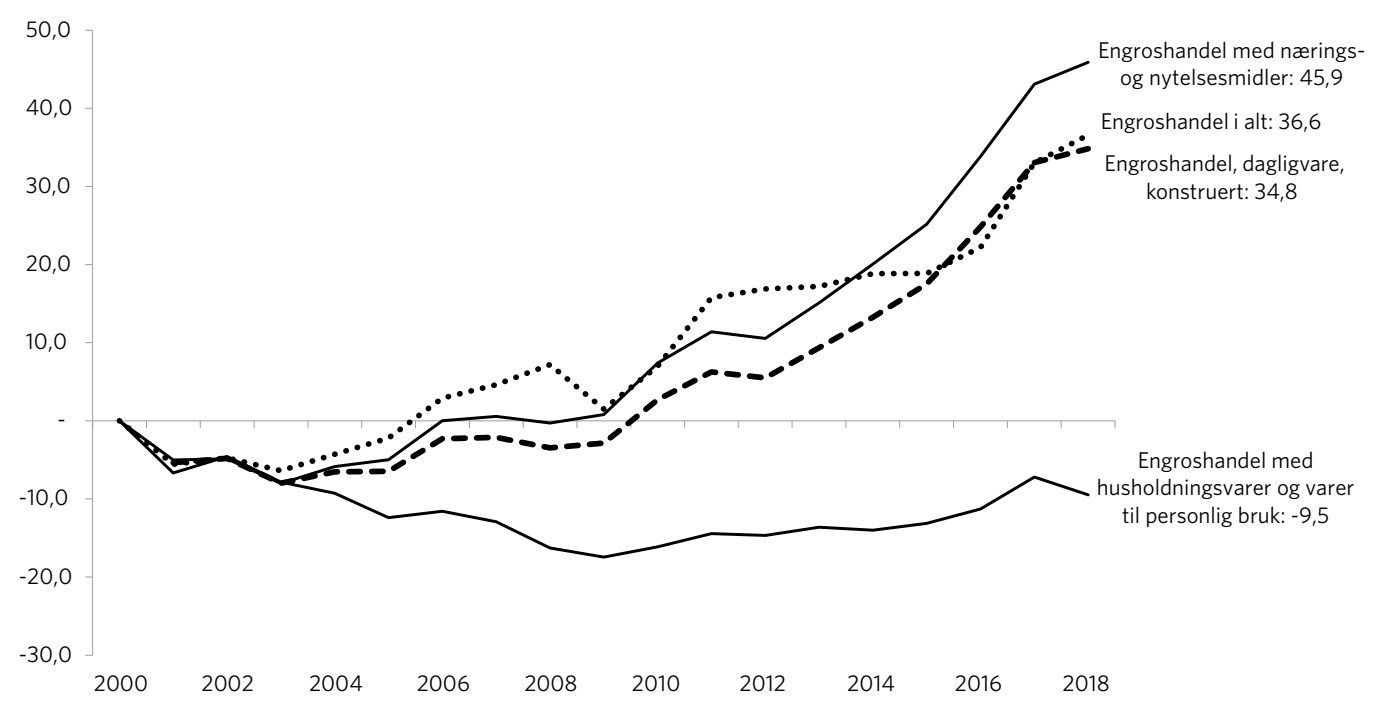

Figur 9 Engrosprisindekser, matvarer og husholdningsvarer, samt konstruert indeks for dagligvarer. Differanse i prosentpoeng til konsumprisindeks (KPI), matvarer, basert på indekser, 2000=100. Kilde: SSB. 
Detaljistleddet har dempet den prisstigningen vi så på produsent og engrosleddet for konsumentene. For detaljhandel med bredt vareutvalg (supermarkeder dominert av næringsmidler) gir prisindeksene en nedgang i prisindeksen for bearbeidingsverdien som, isolert sett, bidrar til økt arbeidsproduktivitet for gitt produksjons- eller omsetningsverdi og sysselsetting. Sammenligningen av prisindeksene tyder altså, isolert sett, på reduserte bruttomarginer i prosent på dagligvareleddet totalt og detaljistleddet spesielt. Prisindeksen for innkjøp av handelsvarer, dvs. den konstruerte engrosprisindeksen for dagligvarer, har steget 34,8 prosent mer enn konsumprisindeksen for matvarer (jf. figur 9 og Pettersen, 202O, se kap 4).

Figur 10 viser beregnet prisindeks for dagligvarehandel på detaljistleddet. Prisindeksen er kompensert for endringer i merverdiavgiften og medregnet samme andel andre forbruksvarer enn matvarer, som for den konstruerte engrosprisindeksen i figur 9. Justeringen for momsendringer $ø$ ker prisindeksen i 2018 med 9,2 prosentpoeng, mens selve forskjellen på normal moms på 25 prosent og matmoms på 15 prosent utgjør en pris$ø$ kning på 8,7 prosent.

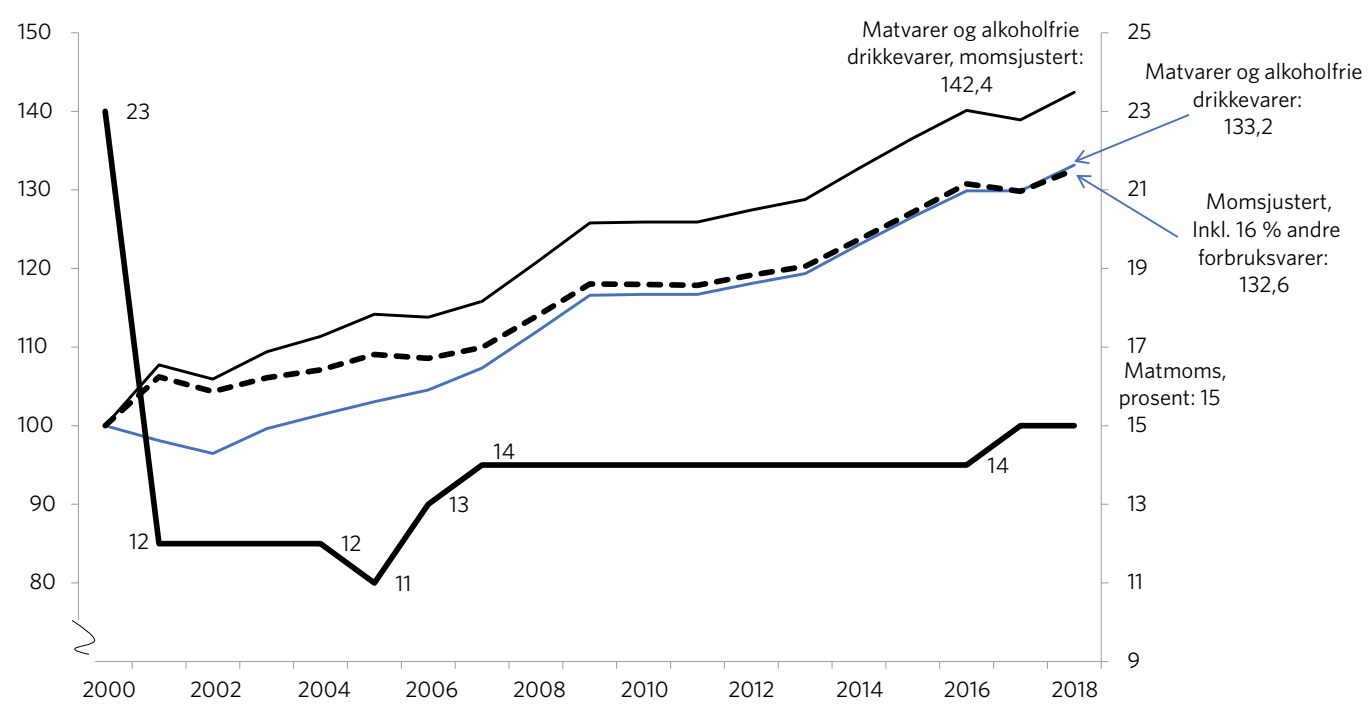

Figur $10 \mathrm{KPI}$ for matvarer og alkoholfrie drikkevarer, samt konstruert prisindeks for omsetning fra dagligvarehandel, detaljistleddet. Prisindekser og momssats for matvarer, prosent (høyre akse), 2000-2018. 2000=100. Kilde: SSB prisstatistikk, egne beregninger. 


\section{Bransjeavgrensning}

Før vi beregner bearbeidingsverdiene, må vi avgrense bransjer og næringer. Figur 11 viser at engroshandel med bredt utvalg av nærings- og nytelsesmidler stort sett utgjør minst halvparten av samlet engroshandel med nærings- og nytelsesmidler, med unntak for antall foretak. Resten av engroshandelen domineres av sjømat. Når det gjelder antall foretak er sjømat den største bransjen.
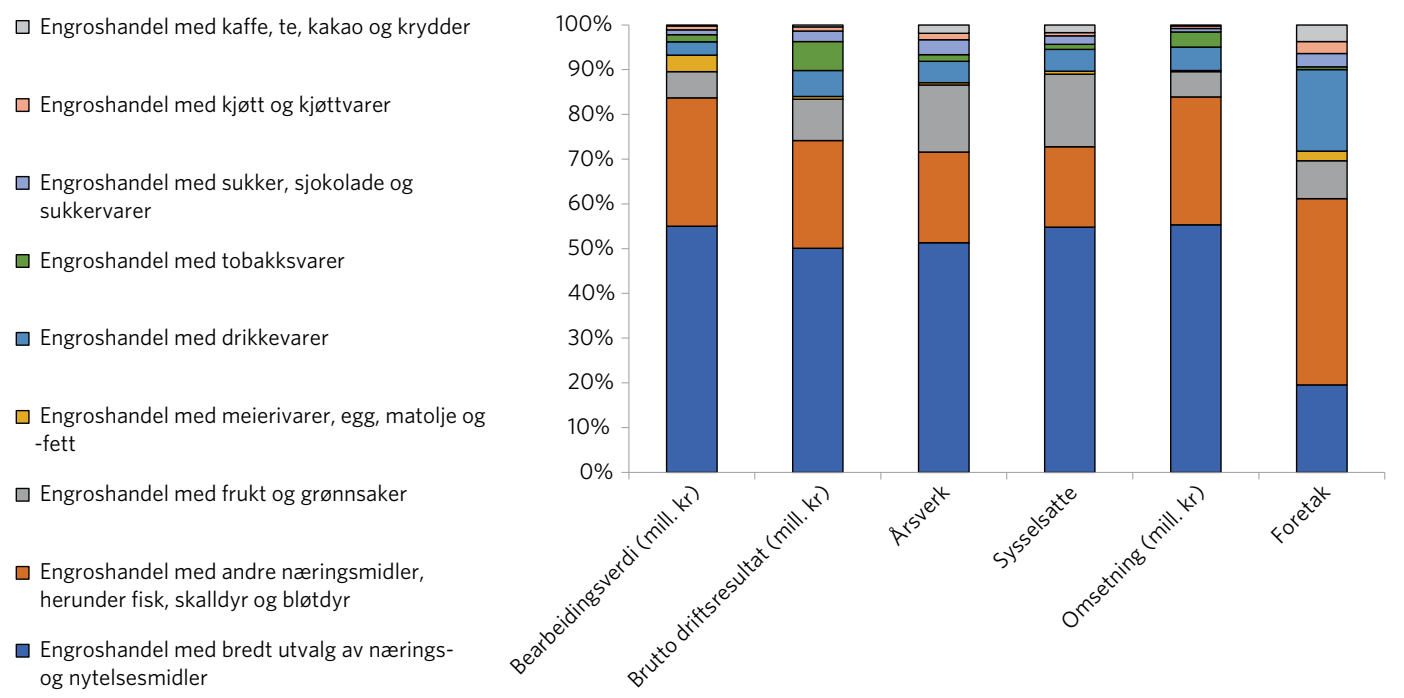

Figur 11 Sammensetning av engroshandel med matvarer og andre nærings- og nytelsesmidler, fordeling på enkeltbransjer. Gjennomsnittstall for 2015-2017. Kilde: SSB, strukturstatistikk for varehandel.

I vår definisjon av relevant engroshandel inkluderer vi engroshandel med bredt utvalg av nærings- og nytelsesmidler (næring 46.39) pluss engroshandel med frukt og grønnsaker (næring 46.31). Denne delen av engroshandelsleddet, som betjener supermarkedkjedene med frukt og grønnsaker, er spesialisert og drives utenfor engroshandel med bredt vareutvalg, primært gjennom Bama-gruppen, som betjener både NorgesGruppen og Rema-gruppen.

På detaljistleddet ser vi kun på detaljhandel med bredt vareutvalg med hovedvekt på nærings- og nytelsesmidler (næring 47.11). Denne 
kategorien favner supermarkedene hvor matvarer og andre nærings- og nytelsesmidler dominerer varesortimentene.

\section{Bearbeidingsverdier}

Figur 12 viser den delen av dagligvarehandelen som analyseres nærmere ved omsetningsverdier og bearbeidingsverdier i løpende priser. Omsetningstallene viser at engroshandelen for supermarkedsdelen i 2017 har høyere omsetning enn detaljistleddet. En rimelig forklaring er at grossister omsetter en stor andel varer utenfor dagligvarehandelen, i tillegg til bransjeintern handel og, antagelig, noe til eksport. Bransjeintern omsetning kan f.eks. foregå mellom sentrale grossistledd og regionale grossistforetak. Det er neppe grunn til å regne med vesentlig bransjeintern omsetning mellom detaljistkjedene.

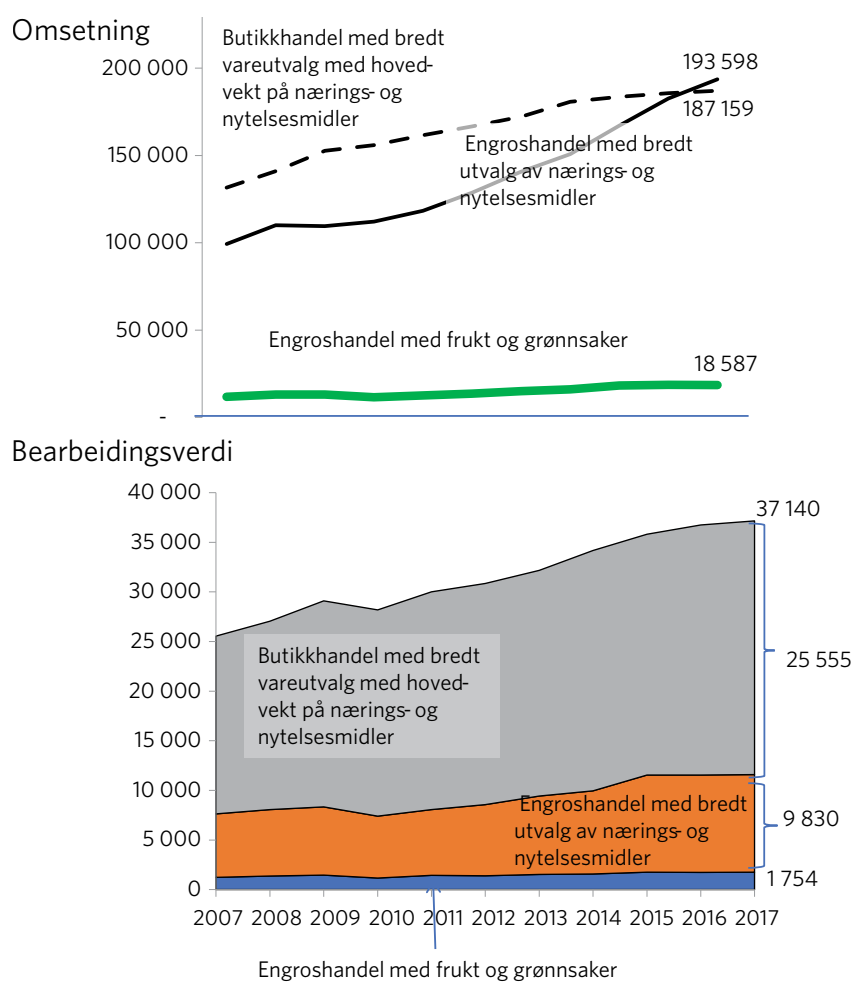

Figur 12 Avgrenset dagligvarehandel, engros og detaljistledd. Omsetning og bearbeidingsverdi i løpende priser. Mill. kroner. 2007-2017. Kilde: SSB, strukturstatistikk. 
Fordelingen av bearbeidingsverdier (nederst i figur 12) understøtter forklaringen med bl.a. stor, bransjeintern omsetning på engrosleddet. Detaljistleddet har mellom to og tre ganger så høy bearbeidingsverdi som engrosleddet. Engroshandel med frukt og grønt med bearbeidingsverdi på ca. 1,8 milliarder i 2017 (se nederste del av arealet i figuren) regnes, som nevnt, med til den relevante engroshandelen for butikkhandel med bredt vareutvalg, dvs. supermarkedene.

Omregning av bearbeidingsverdi til faste priser skjer ved prisindekser som er gjennomgått og beskrevet ovenfor. Figur 13 viser beregningen av bearbeidingsverdi. Figuren viser, steg for steg, endringen fra gjennomsnittet av 2007 og 2008 til gjennomsnittet ni år senere. Endringen blir fordelt på endring i omsetning, endring i kostnad for handelsvarer, endring i kostnad for andre varer og tjenester som forbrukes i produksjonen, og, til sist, en uforklart residual. Endringen beregnes for løpende og faste priser (henholdsvis øvre og nedre del av figuren) slik at man kan se priseffektene. Beregningen er gjort for dagligvarehandel under ett, dvs. samlet for grossistledd og detaljistledd. Nedre del refererer også hvilke prisindekser som er benyttet ved beregningen. Prisjusteringen skjer med indekser som har 2015 som basisår. Figuren viser at bearbeidingsverdi i løpende priser er økt med 53 prosent, mens økningen regnet i faste priser er på 83 prosent. 
KAPITTEL 3

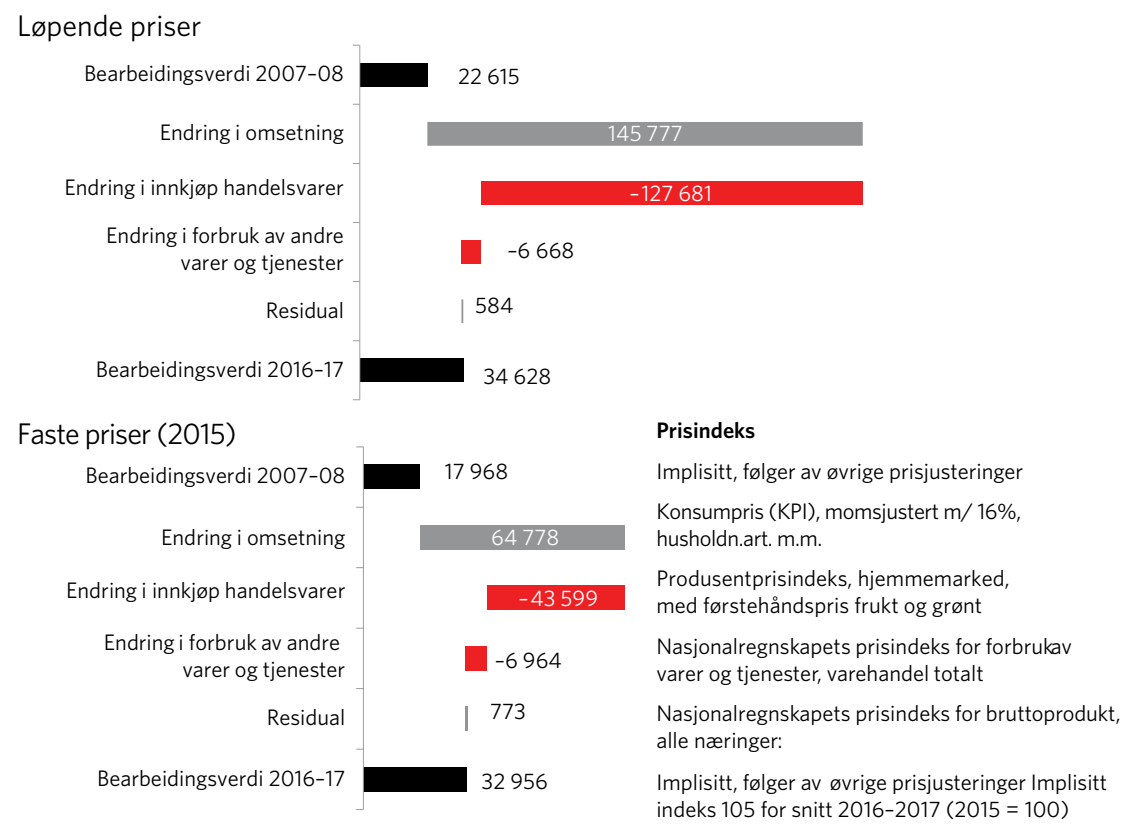

Figur 13 Endring i bearbeidingsverdier fra snitt 2007-08 til 2016-17, oppdelt i fire faktorer. Dagligvarehandel samlet for engros- og detaljistledd. Løpende og faste 2015-priser. Kilde: SSB strukturstatistikk varehandel, diverse prisstatistikk: konsumpriser og nasjonalregnskapets prisindekser.

Klart sterkere vekst i bearbeidingsverdi i faste enn i løpende priser skyldes at distribusjonsleddene har dempet prisstigningen fra førstehånds- og industrileddet før den treffer forbrukerne. Årsakene finnes i gjennomgangen av prisindeksene ovenfor. For det første har innkjøpsprisene fra industrien til dagligvarehandelen steget mer enn forbrukerprisene. En viktig bidragsyter til vekst i bearbeidingsverdien er også at forbruket av varer og tjenester på distribusjonsleddene har sunket, både regnet i løpende og faste priser. Dagligvarehandelen yter altså mer til å redusere prisene over perioden, særlig når vi måler i faste priser. Den økte ytelsen må sees i forhold til endringen i arbeidskraftforbruket for å se om arbeidsproduktiviteten er økt. 
Analysen av endringen i bearbeidingsverdi gir ingen fullstendig forklaring. Residualen i figuren er forklart nærmere i boks 5 nedenfor.

\section{Boks 5. Residualen i beregnet bearbeidingsverdi}

Strukturstatistikken til SSB gir ikke mulighet for å følge beregningen av bearbeidingsverdi fullt ut. Bruker vi symbolene i avsnittet om nøkkelbegreper, boks 2, er residualen denne:

$$
\text { Residual }=\text { O-H-F-B. }
$$

Residualen vil ut fra definisjonene hos SSB være relatert til beholdningsendringer - spesielt varelagre, og, antagelig, subsidier og avgifter (jf. Pettersen 2020, se kap 4). Strukturstatistikken gir ikke mulighet for å definere denne nærmere. Den residualen som fremkommer er varierende, og stor, i starten av perioden. Av en grunn vi ikke har kunnet identifisere, er residualen særlig stor i 2008, og dette året er derfor erstattet med interpolering i løpende statistikk.

Bruken av arbeidskraft i dagligvarehandelen regnes i årsverk som finnes i strukturstatistikk for varehandel. Figur 14 viser at detaljistleddet utgjør om lag 80 prosent av samlet årsverkstall. Det er altså igjen detaljistleddet som dominerer i beregningen for dagligvarehandelen under ett. Sysselsettingen er totalt sett relativt stabil for perioden sett under ett. 


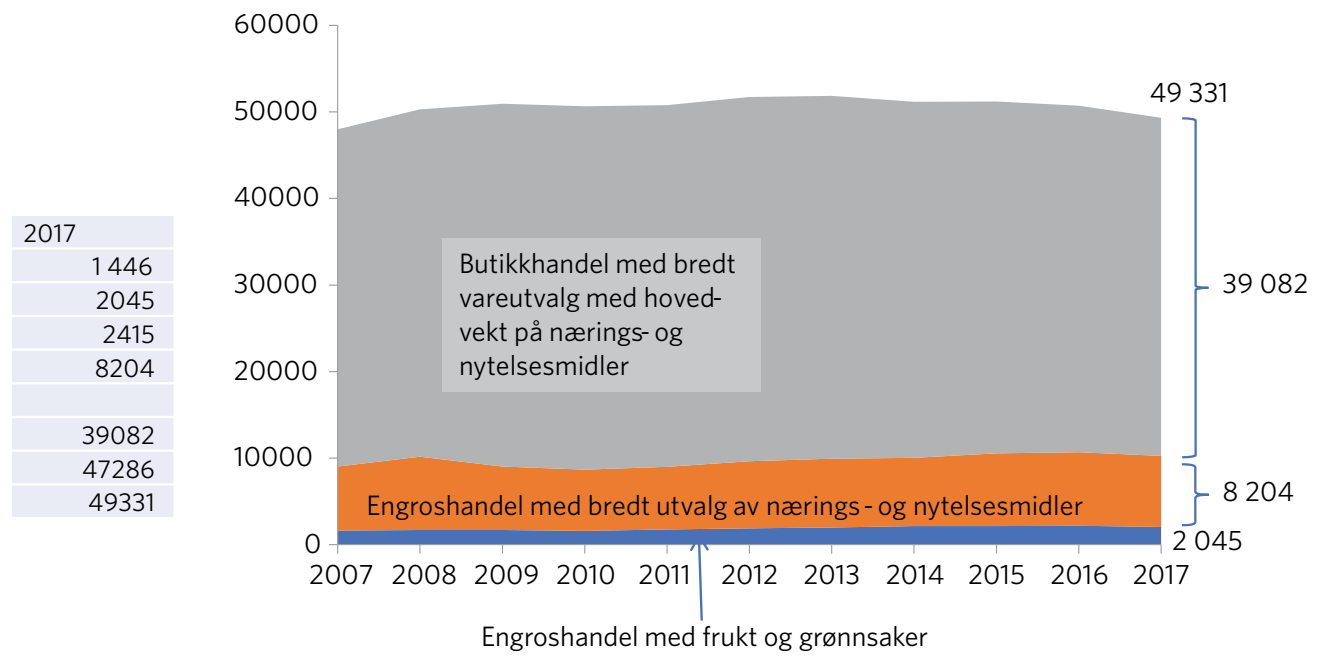

Figur 14 Antall årsverk i dagligvarehandel; engros og detalj. 2007-2017. Kilde: SSB, strukturstatistikk for varehandel.

\section{Veksten i dagligvarehandelens arbeidsproduktivitet}

Endringen i arbeidsproduktivitet framkommer, som nevnt, ved at årlig bearbeidingsverdi i faste priser divideres med arbeidsinnsats. Figur 15 viser beregnet arbeidsproduktivitet i løpende og faste priser for dagligvarehandelen, dvs. sum av engros- og detaljhandel, under ett. Det er to varianter for begge variabler; medregnet og uten residual. Residualen fremkommer ved sammenligning av differansen omsetning minus kjøp av handelsvarer og øvrig forbruk av varer og tjenester, og oppgitt bearbeidingsverdi (jf. boks 4 ovenfor). 


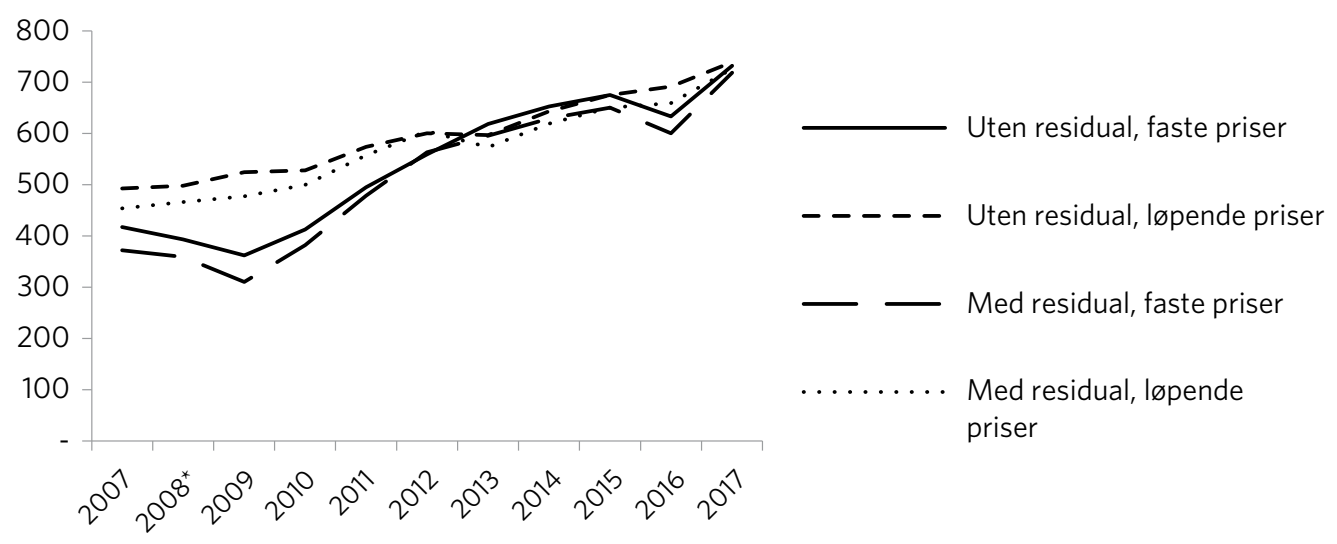

Figur 15 Arbeidsproduktivitet; estimater for dagligvarehandel engros- pluss detaljistledd under ett. 1000 kroner, faste og løpende priser. 2007-2017. Note: * betyr at år 2008 er beregnet verdi ved lineær regresjon basert på øvrige årsdata (jf. boks 4 for forklaring). Kilde: SSB regnskaps- og prisstatistikk; egne beregninger.

Figuren viser at overgangen fra løpende priser til faste priser gir økt vekst i bearbeidingsverdi pr. enhet arbeidsinnsats og at denne, regnet $\mathrm{i}$ faste priser, har en «knekk» i 2008 og 2009. Knekken skyldes svingninger i relative prisindekser for inngående og utgående varer. Tidspunktet henger sammen med den internasjonale finanskrisen som startet 2008, omtrent samtidig med en foreløpig topp i verdens matvarepriser som ble betegnet som en global matvarekrise (FAO, 2011, s. 21-31). Residualen er, som nevnt i boks 5, særlig stor i 2008. Som en konsekvens er statistikken for 2008 erstattet av en lineær funksjon av observasjonene i 2007 og årene 2009-2017.

På grunn av priseffekten og usikkerheten rundt tallene for $2008 \mathrm{og}$ 2009 i starten av perioden viser tabell 3 (under) beregnet gjennomsnittlig produktivitetsvekst i prosent per år fra 2007 til 2017 og fra snitt 2007-08 til snitt 2016-17. Tabell 3 viser enkeltelementene i regnestykket for bearbeidingsverdien og produktivitetsveksten for utvalgte år. Fullstendig tabell finnes i vedlegg.

Tabellens tall for bearbeidingsverdi pr. årsverk viser at det er grunn til å konkludere at produktivitetsveksten for arbeidskraften i dagligvarehandelen samlet (med engrosledd og supermarkeder) ligger over fire prosent årlig. Den kan være høyere, men store variasjoner i priseffekter og i verdien av den omtalte residualen gir grunn til å en viss forsiktighet. 
Estimatet på noe over fire prosent ligger relativt nær nasjonalregnskapets beregnede produktivitetsvekst for butikkhandel totalt, dvs. innenlandsk detaljhandel for alle bransjer (jf. figur 1), men er vesentlig høyere enn estimatet for samlet varehandel. Det er engroshandelen som trekker samlet norsk varehandel ned. Vi skiller ikke mellom engros- og detaljhandel i tabell 3. Det skyldes stor usikkerhet om engrosleddet, f.eks. når det gjelder prisindekser. Det er imidlertid neppe grunn til tvil om at forholdet mellom engros- og detaljistledd, grovt sett, er det samme i dagligvarehandelen som i varehandel totalt. Våre data tilsier vesentlig lavere produktivitetsvekst i engrosleddet enn på detaljistleddet i dagligvarehandelen, noe som i seg selv fortjener nærmere analyse.

Tabell 3 Beregnet arbeidsproduktivitet, dagligvarehandel; engros- og detaljistledd. Utvalgte år, 2007-2017, med gjennomsnittlige årlige vekstrater.

\begin{tabular}{|c|c|c|c|c|c|c|c|}
\hline & 2007 & $2008^{\star}$ & 2009 & 2016 & 2017 & $\begin{array}{r}2007- \\
17\end{array}$ & $\begin{array}{r}2007 / 08- \\
2016 / 17\end{array}$ \\
\hline & \multicolumn{5}{|c|}{ Milliarder kroner, faste priser } & \multicolumn{2}{|c|}{ Årlig endring, \% } \\
\hline Omsetning & 303 & 309 & 319 & 369 & 373 & 2,0 & 2,1 \\
\hline Handelsvarer & 261 & 266 & 274 & 307 & 307 & 1,6 & 1,7 \\
\hline $\begin{array}{l}\text { Andre varer og } \\
\text { tjenester }\end{array}$ & 22 & 24 & 26 & 29 & 30 & 2,8 & 2,4 \\
\hline $\begin{array}{l}\text { Estimert } \\
\text { bearbeidingsverdi, } \\
\text { før residual }\end{array}$ & 20 & 20 & 18 & 32 & 36 & 4,8 & 5,9 \\
\hline Residual & $-2,2$ & $-1,7$ & $-2,6$ & $-1,7$ & $-0,7$ & 2,5 & $-2,9$ \\
\hline $\begin{array}{l}\text { Estimert } \\
\text { bearbeidingsverdi, } \\
\text { medr. residual }\end{array}$ & 18 & 18 & 16 & 30 & 35 & 5,2 & 6,4 \\
\hline Årsverk (1000) & 48,0 & 50,3 & 50,9 & 50,7 & 49,3 & 0,6 & 0,4 \\
\hline $\begin{array}{l}\text { Bearbeidingsverdi pr. } \\
\text { årsverk, } \\
\text { før residual, } \\
\text { faste priser (1000 kr) }\end{array}$ & 417 & 393 & 362 & 633 & 732 & 4,3 & 5,5 \\
\hline $\begin{array}{l}\text {--- løpende priser } \\
\text { (1000 kr) }\end{array}$ & 493 & 498 & 524 & 692 & 740 & 3,4 & 3,6 \\
\hline $\begin{array}{l}\text { Bearbeidingsverdi pr. } \\
\text { årsverk, medregnet } \\
\text { residual, faste priser } \\
\text { (1000 kr) }\end{array}$ & 372 & 359 & 311 & 600 & 719 & 4,9 & 6,1 \\
\hline $\begin{array}{l}\text {-- løpende priser } \\
\text { (1000 kr) }\end{array}$ & 454 & 466 & 478 & 659 & 726 & 3,8 & 4,0 \\
\hline
\end{tabular}

Note: * betyr at år 2008 er beregnet verdi ved lineær regresjon basert på øvrige årsdata (jf. boks 4). Kilde: SSB regnskaps- og prisstatistikk; egne beregninger. 


\section{Veksten i næringsmiddelindustriens arbeidsproduktivitet}

Statistikken for produktivitetsveksten i næringsmiddelindustrien finnes i nasjonalregnskapet. Det er også mulig å skille mellom elementene i beregningen og foreta prisjusteringer for hvert element enkeltvis for næringsmiddelindustrien, som vi har gjort for dagligvarehandelen. Dette er forsøkt, og kan gi noe mer innsikt i betydningen av prisindeksene. Men ut fra de dataene vi har blir avvikene store, og usikkerheten knyttet f.eks. til forståelsen av avgifter og tilskudd er også stor. Vi holder oss derfor til nasjonalregnskapstallene.

Anslagene for vekst i bruttoprodukt (bearbeidingsverdi) i løpende priser ligger på 2,3 prosent årlig for samlet næringsmiddelindustri i nasjonalregnskapet. Når vi ekskluderer den primært eksportrettede sjømatdelen av verdiskapingen, halveres veksttakten i bruttoproduktet. Figur 16 viser også antall timeverk for tre ulike avgrensninger av næringsmiddelindustrien. Skillet mellom næringsmiddelindustrien som helhet og den delen av næringsmiddelindustrien som retter seg mot norsk detaljhandel, har stor betydning for resultatene.

Nederste del av figuren viser at endringen i sysselsettingen oppveier noe av forskjellen mellom sjømatindustri og annen næringsmiddelindustri. Mens sysselsettingen i perioden falt med 0,2 prosent årlig for næringsmiddelindustrien under ett, falt den med ett prosent årlig når vi korrigerer for den eksportrettede delen av sjømatindustrien. Hverken for bearbeidingsverdi eller sysselsetting er det særlig vesentlig om vi inkluderer produksjon av drikkevarer utenom øl og mineralvann og fôrindustrien for husdyrfôr eller ikke. 
Bearbeidingsverdi, løpende priser. Millioner kroner

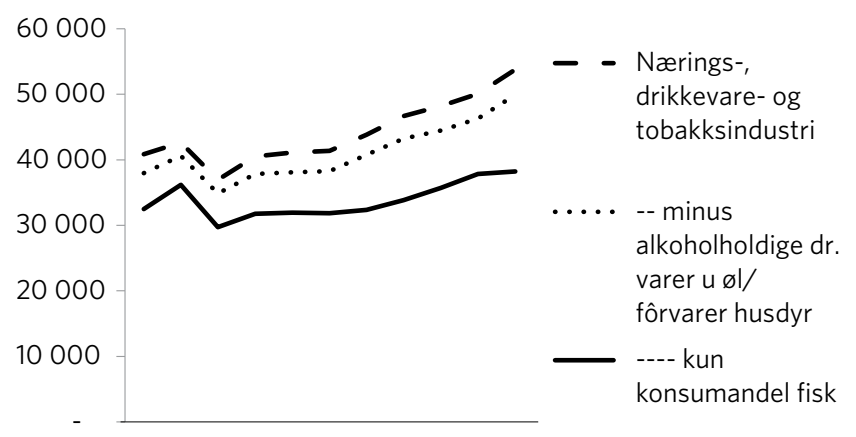

Gjennomsnittlige årlige vekstrater fra 2007/08 til 2016/17

$2,4 \%$

$2,3 \%$

$1,1 \%$

Timeverk, millioner

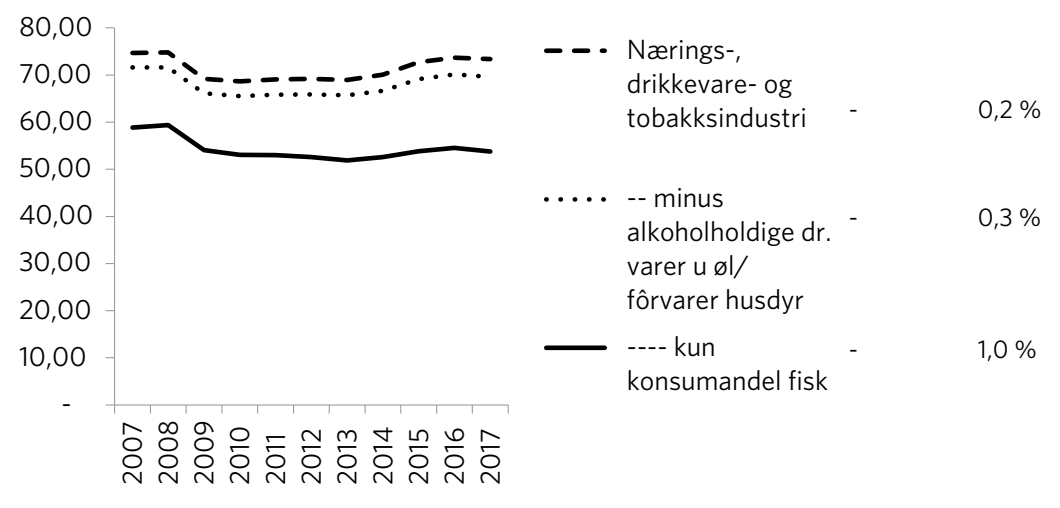

Figur 16 Næringsmiddelindustri. Bearbeidingsverdi til markedspriser og antall timeverk, tre alternative avgrensninger av næringen, 2007-2017. Kilde: SSB, strukturstatistikk.

Fra nasjonalregnskapets produktivitetstall finner vi offisielle tall for arbeidsproduktivitet, som i hovedtrekk ble vist i figur 1 . Her har vi ingen fininndeling av næringsmiddelindustrien som tilsvarer inndelingen i figuren ovenfor, men vi kan skille mellom sjømatindustri og annen næringsmiddelindustri. Figuren viser at de alternative avgrensningene av næringen her har liten betydning for arbeidsproduktivtetsveksten som uansett ligger mellom 2,5 og 3 prosent årlig (figur 17). 


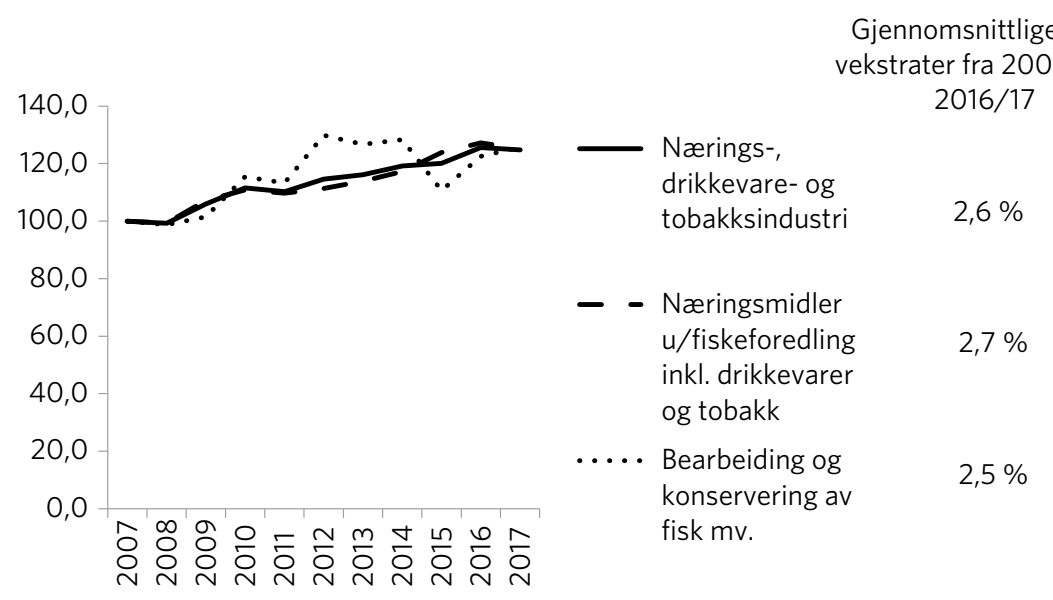

Figur 17 Utvikling i arbeidsproduktivitet. Nærings-, drikkevare og tobakksindustri, alternative avgrensninger. Indeks i faste priser, 2007-2017. 2007=100. Kilde: SSB, nasjonalregnskap.

\section{Arbeidsproduktivitet oppsummert}

Analysen avdekker en del usikkerhet rundt beregningen av produktivitet, men vi ser fire ganske sikre trekk ved utviklingen i arbeidsproduktiviteten i verdikjeden for matvarer.

\section{Fire konklusjoner}

Matsektoren, som norsk noringsliv ellers, gjennomgår en svekkelse av produktivitetsveksten. Den svekkelsen som vi for perioden 2011 til 2017 sammenlignet med foregående tiår, er signifikant for bl.a. detalj- og engroshandel totalt. Med høy andel dagligvarehandel, er det grunn til å regne med at svekkelsen også gjelder dagligvarehandelen. Våre egne estimater for produktivitetsveksten i dagligvarehandel fra 2007-2017 ligger også noe under estimatene for varehandel totalt i tiåret fra 1998 (jf. tabell 1). Det er også svekket produktivitetsvekst i de siste ti år for 
næringsmiddelindustrien, men den er mindre signifikant og mest markant for sjømatindustrien, som for øvrig er i sterk vekst (jf. figur 1).

Produktivitetsveksten er høyere i dagligvarehandelen enn i noeringsmiddelindustrien. Primærproduksjonen har også relativt sterk produktivitetsvekst, men er klart svekket for akvakultur. Forskjellen mellom dagligvarehandelen og matindustrien samsvarer med forskjellen mellom industri og varehandel generelt. Forklaringene er derfor neppe at dagligvarehandelen er annerledes enn annen varehandel. Snarere kan digitale løsninger, mer strømlinjeformet logistikk og automasjon i håndtering av varestrømmer generelt være mer til gunst for handelsleddene enn for industrileddet.

Videre forklarer prisutviklingen alene i stor grad konklusjonen. Det er over tid vesentlig lavere prisvekst fra dagligvarehandel mot forbruker, enn det er på leddet inn mot engroshandel med næringsmidler. Det tilsier i seg selv økt effektivitet, eller billigere dagligvaretjenester. I beregningen betyr det at all omregning fra løpende priser til faste priser vil gi et løft for produktivitetsveksten i dagligvarehandelen. Sammenligningen av investeringstallene gir ikke grunn til å regne med at konklusjonen ville blitt annerledes om vi hadde sett på total faktorproduktivitet.

Produktivitetsveksten er høyere på detaljistleddet enn på engrosleddet $i$ dagligvarehandelen. Vi finner betydelige forskjeller på utviklingen på de to leddene i varehandel totalt, og sannsynligvis gjelder tilsvarende forskjell også dagligvarehandelen. I kapittel 4 finner Pettersen (2020) også betydelig forskjell i bruttomarginutviklingen for de to leddene, sammenlignet med utviklingen i Danmark og Sverige. Om resultatene skal brukes til å indikere hvor konsentrasjonen i dagligvarehandelen kan ha ført til markedsmakt og ekstraordinær marginvekst, er det derfor mest naturlig å se på engrosleddet. Som nevnt har detaljistleddet virket dempende på prisveksten for dagligvarer. På grunn av betydelig vertikal integrasjon mellom de to leddene, er det imidlertid heller ikke uten videre relevant å drøfte tradisjonell markedsmakt i forholdet mellom engros- og detaljistleddet. Spørsmålet kan heller dreie seg om hvordan kjedene regulerer forholdet mellom de to vertikale leddene, og her vil variasjonen i vertikale styrings- og koordineringsformer kunne ha stor betydning. Norsk dagligvarehandel har både innslag av full vertikal integrasjon, selvstendig detaljistforetak og franchise-modeller. 
Stadig mer betydningsfull sjømatnoring. Den fjerde robuste observasjonen er at sjømatsektoren er i ferd med å få en avgjørende betydning for næringsmiddelindustrien og matsektoren som helhet. Det er forskjell på utviklingen i en næringsmiddelindustri medregnet hele sjømatindustrien, og den næringsmiddelindustrien som retter seg mot norsk forbruk. Videre er det stor forskjell på prisutviklingen for innsatsvarer og handelsvarer til norsk matindustri og dagligvarehandel sammenlignet med den samlede førstehånds- eller engrosomsetningen av matvarer i Norge inklusiv all sjømat. De store endringene i internasjonale priser på sjømat, samt sterk vekst i volumene, gjør det viktig å skille mellom en eksportrettet, norsk matindustri og engroshandel, og den delen som er hjemmemarkedsorientert.

Når det gjelder usikkerhet og nødvendige forbehold, er det flere momenter som kan nevnes. I det følgende organiseres momentene etter gangen i beregningene, før noen avsluttende kommentarer om tolkning og fremtidige arbeidsoppgaver.

\section{Hvor står vi, og hvor bør veien gå videre?}

Som det fremgår av analysen vår er det både utfordringer med hensyn til datatilgang, usikkerhet med hensyn til hva som måles, og dermed generell usikkerhet med hensyn til faktisk produktivitetsutvikling i matvarebransjen. Under oppsummerer vi og diskuterer noen av disse.

\section{Usikkerhet og datasvakheter}

Nedenfor peker vi på fire usikkerhetsmomenter som bl.a. skyldes datatilfanget.

\section{Bearbeidingsverdiene}

Bearbeidingsverdien i nasjonalregnskapet (bruttoproduktet) uttrykker næringens bidrag til den nasjonale verdiskapingen. I matsektoren skaper håndteringen av avgifter og subsidier betydelig usikkerhet. Matsektoren 
er en stor avgifts- og subsidiesektor, og det er langt fra bare primærleddet i jordbruket som er omfattet av tung, offentlig avgiftspolitikk.

Fordelingen av bearbeidingsverdiene mellom enkeltledd avhenger av prisobservasjonene, som omtales i neste avsnitt. Feil i prisstatistikken kan gi feil fordeling mellom leddene som bl.a. er omtalt i Pettersen et al. (2015).

\section{Prisindeksene}

Prisindeksene er avgjørende. Relativ vekst i arbeidsproduktivitet er i stor grad forklart av relativ utvikling i omsetnings- og innkjøpspriser for handelsvarer. Siden bearbeidingsverdien bare utgjør en liten del av total omsetning, vil små feil i prisindeksene ha stor betydning for beregnet bearbeidingsverdi i faste priser. Beregningene viser da også betydelige utslag av prisjusteringen fra år til år og mellom sektorer.

Registreringen av priser på ulike ledd, og etableringen av indekser, skaper utfordringer. Det skal f.eks. skilles mellom nye og allerede eksisterende produkter, produktene skal vektes og indekser skal kobles sammen til kontinuerlige indekser over tid gitt varierende vareutvalg og vekting av enkeltprodukter. Det finnes mye teori om hvordan indeksene utarbeides, men langt mindre forskningsbasert kunnskap om hva man registrerer og hvordan sikre at tallene uttrykker det vi ønsker. Pettersen et al. (2015) drøfter bl.a. spørsmål om registrering av rabatter og sidebetalinger for tilleggstjenester ut over selve varene. Praksis har betydning både for prismål og verdimål, dvs. både selve prisindeksen og beregnet bearbeidingsverdi. Bearbeidingsverdi definert som lønnskostnader og brutto driftsresultat inkluderer alle betalinger mellom leverandør og kunde som ikke føres som varekostnad. Slike betalinger kan være betalinger for tjenester, som f.eks. felles markedsføring (joint marketing), men økning i disse kan også overdrive bearbeidingsverdien og undervurdere innkjøpsprisene for handelsleddet, motsatt for leverandørleddet, dvs. overdrive produktivitetsveksten.

Eventuelle feil i føringen av slike poster vil trolig først og fremst gjelde for engrosledd, og ikke for detaljistledd. Prisutviklingen for engroshandel med dagligvarer tyder på en gunstig prisutvikling for dette leddet. Det er publisert prisobservasjoner som kan tyde på at engroshandelens 
innkjøpspriser har hatt en mer gunstig utvikling for engroshandelen, enn det den offisielle statistikken viser (Oslo Economics, 2015). Denne alternative prisstatistikken er imidlertid ikke godt dokumentert. Om den skulle være riktig, vil produktivitetsveksten på industrileddet være noe undervurdert, og på engrosleddet noe overvurdert. På detaljistleddet er den alternative prisstatistikken uten betydning. Detaljistleddet utgjør minst dobbelt så høy bearbeidingsverdi som engrosleddet. Hovedkonklusjonene blir derfor ikke endret.

I analysen har vi brukt ulike regnemåter for handelsledd og industriledd. Grunnen er dataene i offisiell statistikk. Nasjonalregnskapet offentliggjør produktivitetstall for næringsmiddelindustri på flere nivår av aggregering, mens vi for varehandelen kun finner oppdeling på samlet detaljhandel og samlet engroshandel. Derfor har vi vurdert alternative prisindekser. Valget av prisindekser har betydning for resultatet, men vi har også vist at forskjellen mellom de alternative prisindeksene er begrensede. Det er først og fremst engrosprisindeksen som skiller seg fra andre indekser. Den høye engrosprisindeksen gir negativ effekt på produktivitetsveksten i engrosleddet, og påvirker ikke produktivitetsveksten i samlet dagligvarehandel.

For nasjonalregnskapet er det ikke enkelt å finne informasjon om selve sammensetningen av prisindeksene for beregning av bruttoprodukt $\mathrm{i}$ faste priser. Vi har derfor også forsøkt en alternativ beregning av produktivitetsveksten i næringsmiddelindustrien som trinnvis omregner omsetning, handelsvarer og andre varer, endog forskjellen mellom bruttoprodukt til markeds- og faktorpriser, fra nominelle til realstørrelser. Det foreløpige resultatet avviker fra de offisielle produktivitetstallene i negativ retning. Så langt har vi ikke hatt grunnlag for å gå nærmere inn på disse beregningene. Dette krever ytterligere detaljeringsgrad i data, samt tilgang til bakenforliggende tall benyttet i nasjonalregnskapet før man kan være tilstrekkelig trygg på resultatene.

\section{Usikkerhet ved arbeidskraftforbruket}

For arbeidskraften har vi mengdetall som kan skjule variasjon mellom ulike typer arbeidskraft og innleie. I en nylig rapport har Pettersen og Romsaas (2019) vist at bruk av innleid arbeidskraft er sterkt økende i deler 
av matindustrien, og også i enkelte deler av engroshandelen. Sannsynligvis kan dette være medvirkende til observert vekst i produktiviteten i matindustrien. Et korrekt estimat skulle korrigert for denne bokholderifeilen. Korreksjon ville imidlertid kreve bruk av data for enkeltvirksomheter. I den grad sysselsettingsveksten i industrien er undervurdert, f.eks. som følge av innleie og entrepriser, vil produktivitetsveksten være overvurdert.

Vi har tidligere nevnt at arbeidskraften er behandlet som en homogen ressurs, tross betydelige endringer i sammensetningen av arbeidskraften over tid (von Brasch et al., 2018) og forskjell mellom næringer. I et samfunnsperspektiv kan det også være grunn til å ta hensyn til hvilke slitasjeproblemer virksomhetene medfører i form av yrkesrelatert sykefravær. Når det gjelder sammenligningen mellom næringer er det imidlertid all grunn til å tro at slike utfordringer gjelder på tvers av industri og servicesektorer, og slik sett er det vanskelig å mene noe om hvilken vei dette påvirker det relative forholdet.

\section{Bransjeinndelingen er uklar og til dels overlappende i statistikken}

Bransjeinndelingen er, ved siden av prisindeksene, antagelig den største usikkerhetskilden. Detaljistleddet for dagligvarer er definert ut fra «bredt vareutvalg». Det gir usikkerhet om avgrensing mot brede vareutvalg av konsumvarer med matvarer. Vi har forsøkt å avgrense oss til verdikjeden rettet mot supermarkedene. Det betyr at voksende deler av dagligvareomsetningen holdes utenfor (jf. drøfting av struktur i dagligvarehandel; Friberg, Pettersen, Steen \& Ulsaker, 2020, se kapittel 2).

Som nevnt tidligere selger supermarkedene mange varer som ikke kommer fra næringsmiddelindustrien. Vi har brukt skjønnsmessige anslag for denne delen av omsetningen. Siden prisutviklingen for disse varene avviker fra øvrig prisutvikling, får andelens størrelse også betydning.

På engrosleddet er det også stor usikkerhet om bransjeinndelingen. Dette er diskutert ovenfor. 


\section{Veien videre}

Når man diskuterer produktivitetsvekst kommer ofte spørsmålet om hvorvidt restruktureringen i verdikjeden for matvarer har vært gunstig for forbrukerne.

På bakgrunn av studien, og først og fremst på bakgrunn av en enkel sammenligning av prisserier på de ulike vertikale nivåene, er det grunn til å hevde at dagligvarehandelen demper prisøkningen for forbrukerne i den forstand at prisøkningen på distribusjonsleddene samlet, og særlig siste leddet, er svakere enn på foregående ledd. Høy produktivitetsvekst indikerer at strukturen i dagligvarehandelen ikke er et noe tydelig hinder for omstilling og innovasjon. Den indikerer også at økende effektivitet bidrar til prisdempingen for forbrukerne.

Kartleggingen av produktivitetsvekst er imidlertid ingen analyse av årsaker til denne veksten. Det er f.eks. ikke mulig å si at produktivitetsveksten hadde vært annerledes om vi fortsatt hadde fire større paraplykjeder i Norge, slik situasjon var for noen år siden (dagens tre pluss ICA). ${ }^{4}$ Som diskutert over er det ikke faglig grunnlag for å anta en enkel sammenheng mellom struktur, innovasjon og produktivitetsvekst.

Vår analyse gjør det derfor vanskelig å bruke argument om lav produktivitetsvekst som begrunnelse for endringer i rammebetingelsene for verdikjeden for matvarer. Nærmere analyser kan selvsagt tenkes å avdekke unødige effektivitetstap som vi ikke har kunnet identifisere. I så fall kreves imidlertid andre analyser. Tre veier til mer dyptgående analyse kan være:

- Å styrke statistikkgrunnlaget både når det gjelder prisindekser og bransjeinndeling. Det er underlig at en så stor sektor i norsk økonomi som dagligvarehandelen ikke kan gjenfinnes i nasjonalregnskapet og de offisielle produktivitetsberegningene. Gjennomgående bør det etterlyses et bedre datagrunnlag. For det første er det grunn

4 Lidl var inne i markedet fra 2004 til 2008. Slik sett var det fem aktører disse årene, men Lidl kom aldri opp i mer enn 1,4 \% markedsandel. Til sammenligning har dagens Bunnpris, som er til stede i hele landet, en konsistent markedsandel på mellom 3,5 og $4 \%$. En analyse av Lidls exit fra norsk dagligvarehandel finnes i Utgård (2008) og er også omtalt i Kjuus (2010). 
til å prioritere bedre kilder for forståelsen av avgiftsregnskapet for matnæringene. For det andre er det en bemerkelsesverdig inkonsistens mellom strukturstatistikk for industri og handel som gjør at årsverkstall kun er tilgjengelig for handelen, og ikke for industrien. Det skaper problemer når det gjelder produktivitetsberegninger på relativt detaljert nivå. Grunnlagsdata om produktrelaterte og næringsrelaterte avgifter og subsidier samt prisindekser bør være tilgjengelige. Enkelte av utfordringene kan antagelig løses med spesialkjøringer fra SSB, men det synes klart at denne typen statistikk burde foreligge uten behov for slike kjøringer. Vi har ikke hatt ressurser til å gjøre slike innenfor rammene for denne artikkelen.

- Gjennomgang av bransjeinndelingen. Særlig på engrosleddet er det stor usikkerhet. Ved bruk av mikrodata på foretaksnivå vil det være gode muligheter for å skille landsdekkende distribusjonssentra fra regionale anlegg, og, ikke minst; å skille eksportrettet handelsvirksomhet fra virksomhet rettet mot nasjonale verdikjeder.

- Regionaliserte analyser. Dagligvarehandel er lokal virksomhet understøttet av sentraliserte logistikksystemer. Derfor har konkurransepolitiske vurderinger av strukturendringer, som ved Lidls og ICAs uttreden fra det norske markedet, alltid et lokalt fokus. For dagligvarehandelen er forutsetningen for produktivitetsvekst varierende mellom regioner, mens det for samfunnet er viktige nytteeffekter av et finmasket distribusjonsnett for matvarer. Det er derfor god grunn tilå nedbryte produktivitetsutviklingen på regioner, slik det er gjort for konsentrasjon og butikktetthet f.eks. i Friberg et al. (2020, kapittel 2).

- Renekvantitativeproduktivitetsindikatorer. I næringslivet går sjelden produktivitetsmåling veien om verdier og prisjusteringer. Vi mener næringslivet i større grad kan ha nytte av å vurdere hva som er rene inflasjonseffekter på lønnsomhet, og hva som er effektivitet. Men undersøkelser av produktivitet på næringsnivå kan også ha nytte av den typen kvantitative mål som bedriftene bruker i sine effektivitetsmålinger. I så fall kan indikatorer som måler butikktetthet, antall varelinjer og sortimentsbredde, antall kundetransaksjoner 
osv. være til hjelp ved sammenligning av produktivitet over tid. Av hensyn til bærekraften er det også grunn til å føye til transportarbeid, matsvinn og samlet energibruk.

I sum kan vi fastslå at det gjenstår mer arbeid før man har solid grunnlag for å vurdere utfordringer og virkemidler for å styrke grunnlaget for innovasjon og produktivitetsvekst i norsk verdikjede for matvarer og andre næringsmidler.

Takk for nyttige kommentarer til kapitlet fra Per Ingvar Olsen, BI, og til Siri Voll Dombu, Menon og kollega Agnar Hegrenes for samarbeid spesielt $i$ forbindelse med forutgående studier av produktivitetsutvikling $i$ verdikjeden for matvarer. 


\section{Referanser}

Aahjem, E. P. \& Andersen, H. G. (2017). Koordinering og effektivitivisering i forsyningskjeden: Effektivitetsendringer $i$ KIWI som følge av NGFLYT (Mastergradsavhandling, Norges Handelshøyskole). Hentet fra https://www.nhh. no/contentassets/ef25235953bd4af58671fa1bd5771495/aahjem_andersen.pdf

Aghion P., Bloom, N., Blundell, R., Griffith, R. \& Howitt, P. (2005). Competition and innovation: An inverted-U relationship. The Quarterly Journal of Economics, 120(2), 701-728. https://doi.org/10.1093/qje/120.2.701

Bessonova, E. \& Gonchar, K. (2019). How the innovation-competition link is shaped by technology distance in a high-barrier catch-up economy. Technovation, (86/87), 15-32. https://doi.org/10.1016/j.technovation.2019.01.002

Chopra, S. \& Meindl, P. (2016). Supply chain management (6. utg.). Essex: Pearson.

Eide, K. L. \& Syverinsen, M. H. (2019). Hvordan påvirkes dagligvaremarkedet av nyetablerte bredsortimentsbutikker? En empirisk studie av hvordan Normal-etableringer påvirker Meny-butikker på norske kjøpesentre (Mastergradsavhandling, Norges Handelshøyskole). Hentet fra https://www.nhh. no/contentassets/ef25235953bd4af58671fa1bd5771495/syverinsen_eide.pdf

Food and Agriculture Organization of the United Nations. (2011). The state of food insecurity in the world 2011. Hentet fra http://www.fao.org/3/i2330e/i2330eo4.pdf

Friberg, R., Steen, F., Pettersen, I. \& Ulsaker, S.A. (2020). Annerledeslandet Norge: Butikktilgjengelighet og markedskonsentrasjon i Sverige og Norge. I F. Steen \& I. Pettersen (Red.), Mot bedre vitende i norsk matsektor (Kap. 2, s. 36-71). Oslo: Cappelen Damm Akademisk.

Gabrielsen, T. S. (2010). Betydningen av ulike vertikale relasjoner på konkurranseforhold $i$ verdikjeden for mat (Rapport, Universitetet i Bergen, avlevert Matkjedeutvalget. Vedlegg til NOU 2011:4). Hentet fra https://beccle.no/files/2011/12/rapport-matkjede-endelig10112010.pdf

Gabrielsen, T. S., Steen, F., Sørgard, L. \& Vagstad, S. (2013). Kjøpermakt $i$ dagligvaresektoren (Rapport skrevet for Fornyings-, administrasjons- og kirkedepartementet). Hentet fra https://www.regjeringen.no/no/dokumenter/ kjopermakt-i-dagligvaresektoren/id723054/

Gaasland, I. (2020). Verdikjeden for mat - importbeskyttelse eller konkurranse? I F. Steen \& I. Pettersen (Red.), Mot bedre vitende i norsk matsektor (Kap. 5, s. 158-192). Oslo: Cappelen Damm Akademisk.

Kay, C. D. \& Sørlie, J. F. (2017). Produktivitet i dagligvarehandel: En analyse av produktivitetsutviklingen i NorgesGruppen og ulike norske bransjer 
(Masteravhandling, Norges Handelshøyskole). Hentet fra https://www.nhh.no/ contentassets/ef25235953bd4af58671fa1bd5771495/kay_sorlie.pdf

King, R. P. \& Phumpiu, P. F. (1996). Reengineering the food supply chain: The ECR initiative in the grocery industry. American Journal of Agricultural Economics, 78(5), 1181-1186. http://doi.org/ 10.2307/1243488

Kjuus, J. (Red.) (2010). Dagligvarehandel og mat 2008 (NILF rapport). Oslo: Norsk institutt for landbruksøkonomisk forskning.

Leibenstein, H. (1978). On the basic proposition of x-efficiency theory. The American Economic Review, 78(2), 328-332. Hentet fra https://www.jstor.org/ stable/1816715

NOU 2011: 4. (2011). Mat, makt og avmakt - om styrkeforholdene i verdikjeden for mat. Oslo: Landbruks- og matdepartementet.

NOU 2015: 1. (2015). Produktivitet - grunnlag for vekst og velferd Produktivitetskommisjonens første rapport. Oslo: Finansdepartementet.

NOU 2016: 3. (2016). Ved et vendepunkt: Fra ressursøkonomi til kunnskapsøkonomi Produktivitetskommisjonens andre rapport. Oslo: Finansdepartementet.

Nøkleby, H. \& Søreng, C. (2019). Hva skjer med produktiviteten i kassepunktet når kundene gjør jobben? En empirisk studie av produktivitetseffekten ved innføring av selvbetjente kasser i MENY-butikker (Masteravhandling, Norges Handelshøyskole). Hentet fra https://www.nhh.no/contentassets/ ef25235953bd4af58671fa1bd5771495/nokleby_soreng.pdf

Oslo Economics \& Oeconomica. (2017). Etableringshindringer i dagligvaresektoren (Rapport utarbeidet på oppdrag fra Nærings- og fiskeridepartementet, 2017-46). Hentet fra https://osloeconomics.no/wp-content/uploads/Etableringshindringeri-dagligvaresektoren_ref2.pdf

Oslo Economics. (2015). Prisutvikling i dagligvaremarkedet og butikkprise.

Oslo Economics 2015

Pettersen, I. (2013). Dine og mine merkevarer. I I. Pettersen (Red.), Dagligvarehandel og mat 2013 (s. 135-142). Oslo: Norsk institutt for landbruksøkonomisk forskning. Hentet fra https://nnn.no/wp-content/uploads/2013/11/ DagligvarehandelOgMat2013.pdf

Pettersen, I. (2020). Priser og marginer i verdikjeden for matvarer. I F. Steen \& I. Pettersen (Red.), Mot bedre vitende i norsk matsektor (Kap. 4, s. 124-157). Oslo: Cappelen Damm Akademisk.

Pettersen, I., Dombu, S. V., Hegrenes, A. \& Sørbye, S. E. (2015). Produktivitet i norsk matindustri (NIBIO rapport 2015/1(2)). Hentet fra http://hdl.handle.net/11250/299068

Pettersen, I. \& Romsaas, I. M. (2019). Arbeidskraftens tilknytningsformer i matindustrien; bruk av innleie og underentrepriser vurdert ut fra regnskapsdata (Rapport nr. 5/159/2019). Ås: Norsk institutt for bioøkonomi. 
Ratchford, B. T. \& Brown, J. R. (1985). Study of productivity changes in food retailing. Marketing Science, 4(4), 292-311. https://doi.org/10.1287/mksc.4.4.292

Schumpeter, J. A. (2011). Capitalism, socialism and democracy (2. utg.). Eastford, CT: Martino Publishing. Originalverket utgitt 1947.

Statistisk sentralbyrå. (2012). Produktivitet og noeringsutvikling (Økonomisk utsyn, Økonomiske analyser 1/2012). Hentet fra https://www.ssb.no/a/publikasjoner/ pdf/oa_201201/o4prod.pdf

Syverson, C. (2011). What determines productivity? Journal of Economic Literature, 49(2), 326-365. http://doi.org/ 10.1257/jel.49.2.326

Tinbergen, J. (1952). The influence of productivity on economic welfare. The Economic Journal, 62(245), 68-86. Hentet fra http://hdl.handle.net/1765/9745

Tirole, J. (2014, desember). Market failures and public policy. Nobelforedrag, Stockholms universitet, 8. desember 2014.

Utgård, J. (2008). Lidl i Norge: Problematisk etablering med varige effekter. I I. Pettersen (Red.), Dagligvarehandel og mat 2008 (s. 59-94)(NILF rapport). Oslo: Norsk institutt for landbruksøkonomisk forskning. Hentet fra http://hdl.handle.net/11250/2488825

Vagstad, S. (2011). Produktivitetsutvikling i leveringskjeden for matvarer.

I I. Pettersen \& T. S. Gabrielsen (Red.), Dagligvarehandel og mat 2011: Perspektiver på verdikjedene for matvarer (s. 37-48)(NILF rapport). Oslo: Norsk institutt for landbruksøkonomisk forskning. Hentet fra http://hdl.handle.net/11250/2463843 von Brasch, T. (2015). The Norwegian productivity puzzle - not so puzzling after all?

(Discussion Papers No. 796, Statistics Norway, Research Department). Hentet fra https://www.ssb.no/en/forskning/discussion-papers/_attachment/216926? ts $=14 \mathrm{~b} 4 \mathrm{a} 2 \mathrm{c} 1168$

von Brasch, T., Cappelen, Å. \& Iancu, D-C. (2018). Measuring labour services:

Quality-adjusting the entry and exit of workers. Scandinavian Journal of

Economics, 120 (2), 597-623. https://doi.org/10.1111/sjoe.12242

von der Fehr, N-H. M. (2013). Vertikale relasjoner. I I. Pettersen (Red.),

Dagligvarehandel og mat 2013 (s. 116-134)(NILF rapport). Oslo: Norsk institutt

for landbruksøkonomisk forskning. Hentet fra https://nnn.no/wp-content/ uploads/2013/11/DagligvarehandelOgMat2013.pdf

Womack, J. P., Jones, D. T. \& Roos, D. (1990). The machine that changed the world. New York: Free Press. 


\section{Vedlegg}

Vedleggstabell V-1 Sammenligning av prisindekser som kan benyttes til å omregne dagligvarehandelens bearbeidingsverdier i løpende priser til faste priser.

\begin{tabular}{|c|c|c|c|}
\hline & Prisindeks & Forklaring & Kilde \\
\hline 1 & $\begin{array}{l}\text { Nærings- og nyt.m.ind.: } \\
\text { produksjonspris }\end{array}$ & $\begin{array}{l}\text { Prisindeks for varer } \\
\text { produsert i nærings- og } \\
\text { nytelsesmidddelindustrien, skal } \\
\text { ekskludere rene handelsvarer. } \\
\text { Aktuell for innkjøp til grossistleddet. }\end{array}$ & $\begin{array}{l}\text { SSB, } \\
\text { nasjonalregnskapet }\end{array}$ \\
\hline 2 & $\begin{array}{l}\text { Nærings- og nyt.m.ind.: } \\
\text { produsentpris }\end{array}$ & $\begin{array}{l}\text { Prisindeks for varer } \\
\text { levert fra nærings- og } \\
\text { nytelsesmiddelindustrien (kan trolig } \\
\text { inkludere handelsvarer). Aktuell for } \\
\text { innkjøp til grossistleddet. }\end{array}$ & SSB, prisindekser \\
\hline 3 & $\begin{array}{l}\text { Næringsm.ind.: } \\
\text { produsentpris }\end{array}$ & $\begin{array}{l}\text { Samme som over, men uten } \\
\text { drikkevarer og tobakk. }\end{array}$ & SSB, prisindekser \\
\hline 4 & $\begin{array}{l}\text { Matvarer, } \\
\text { hjemmemarked: } \\
\text { førstehåndsomsetn. }\end{array}$ & $\begin{array}{l}\text { Prisindeks for alle varer på første } \\
\text { omsetningsledd innenlands, dvs. } \\
\text { inkluderer import. Vil trolig dekke } \\
\text { både råvarer til industri og innkjøp } \\
\text { hos grossist. Aktuell for innkjøp til } \\
\text { grossistleddet. }\end{array}$ & SSB, prisindekser \\
\hline 5 & $\begin{array}{l}\text { Drikkevarer og tobakk, } \\
\text { hjemmemarked: } \\
\text { førstehåndsomsetn. }\end{array}$ & $\begin{array}{l}\text { Samme som over, for drikkevarer og } \\
\text { tobakk. }\end{array}$ & SSB, prisindekser \\
\hline 6 & $\begin{array}{l}\text { Engroshandel med } \\
\text { nærings og nyt.m.ind. }\end{array}$ & $\begin{array}{l}\text { Prisindeks for «Prisar verksemda } \\
\text { oppnår ved sal til sine kunder som } \\
\text { er detaljistar. Prisane vert oppgitt } \\
\text { den 15. i månaden og er eksklusive } \\
\text { meirverdiavgift, men inklusive andre } \\
\text { avgifter.» (https://www.ssb.no/ } \\
\text { engrospris ). Aktuell for innkjøp til } \\
\text { detaljistleddet. }\end{array}$ & SSB, prisindekser \\
\hline 7 & $\begin{array}{l}\text { Konsumpris-indeks: } \\
\text { matvarer og alkoholfrie } \\
\text { drikkevarer }\end{array}$ & $\begin{array}{l}\text { Pris på konsumentleddet, dvs. fra } \\
\text { detaljist. Eneste prisindeks basert } \\
\text { på priser inklusive moms. Brukes for } \\
\text { omsetning fra detaljistleddet. }\end{array}$ & SSB, prisindekser \\
\hline
\end{tabular}


Vedleggstabell V-2 Årlig vekst i arbeidsproduktivitet for sektorer og perioder. Prosent. Beregnede t-verdier på treårs glidende gjennomsnittstall. Observasjonene er rangert etter synkende t-verdi for forskjellen mellom snitt 1998-2007 og snitt 2008-2017.

\begin{tabular}{|c|c|c|c|c|c|c|}
\hline Sektor & $\begin{array}{r}1978- \\
1997\end{array}$ & $\begin{array}{r}1998- \\
2017\end{array}$ & $\begin{array}{r}\text { t-verdi } \\
(\text { kritisk=1,72) }\end{array}$ & $\begin{array}{r}1998- \\
2007\end{array}$ & $\begin{array}{r}2008- \\
2017\end{array}$ & $\begin{array}{r}\text { t-verdi } \\
\text { (kritisk=1,83) }\end{array}$ \\
\hline $\begin{array}{l}\text { Varehandel og } \\
\text { reparasjon av } \\
\text { motorvogner }\end{array}$ & 3,8 & 3,9 & $-0,60$ & 5,1 & 2,6 & 6,44 \\
\hline Akvakultur & 23,0 & 9,2 & 1,51 & 21,5 & $-3,1$ & 6,02 \\
\hline $\begin{array}{l}\text { Agentur- og } \\
\text { engroshandel, unntatt } \\
\text { med motorvogner }\end{array}$ & 4,4 & 4,0 & $-0,05$ & 5,7 & 2,3 & 5,44 \\
\hline $\begin{array}{l}\text { Detaljhandel, unntatt } \\
\text { med motorvogner }\end{array}$ & 5,0 & 5,1 & $-0,43$ & 5,3 & 4,9 & 5,00 \\
\hline $\begin{array}{l}\text { Fiske, fangst og } \\
\text { akvakultur }\end{array}$ & 7,3 & 7,8 & $-0,14$ & 14,3 & 1,2 & 2,22 \\
\hline Industri & 2,0 & 2,4 & $-0,98$ & 2,9 & 2,0 & 1,87 \\
\hline $\begin{array}{l}\text { Bearbeiding og } \\
\text { konservering av fisk mv. }\end{array}$ & $-0,6$ & 3,3 & $-1,56$ & 4,0 & 2,6 & 1,48 \\
\hline $\begin{array}{l}\text { Nærings-, drikkevare- } \\
\text { og tobakksindustri }\end{array}$ & $-0,1$ & 2,4 & $-1,84$ & 2,5 & 2,3 & 1,27 \\
\hline Fiske og fangst & 3,4 & 8,0 & $-1,00$ & 12,2 & 3,8 & 1,21 \\
\hline Jordbruk og skogbruk & 3,7 & 4,9 & $-0,76$ & 6,6 & 3,1 & 0,94 \\
\hline Jordbruk, jakt og viltstell & 2,9 & 5,7 & $-1,56$ & 7,4 & 4,0 & 0,43 \\
\hline $\begin{array}{l}\text { Næringsmidler med } 6 \% \\
\text { sjømat }\end{array}$ & $-0,1$ & 2,6 & $-1,57$ & 3,0 & 2,3 & 0,35 \\
\hline $\begin{array}{l}\text { Næringsmidler u/ } \\
\text { fiskeforedling inkl. } \\
\text { drikkevarer og tobakk }\end{array}$ & $-0,0$ & 2,6 & $-1,34$ & 2,9 & 2,3 & 0,09 \\
\hline
\end{tabular}

Kilde: Analysene er basert på SSB, nasjonalregnskapsstatistikk. Næringsmidler med $6 \%$ sjømat er sammensatt av Næringsmidler u/fiskeforedling inkl. drikkevarer og tobakk og en andel av Bearbeiding og konservering av fisk mv. som tilsvarer andelen sjømat i husholdningenes samlet matvareforbruk regnet i kroner. 
Forklaring:

Tabellen viser, for sammenligning av tyveårsperiodene 1978-1997 og 1998-2017, at

- Alle viste sektorer utenom akvakultur og agentur- og engroshandel har en økning i gjennomsnittlig årlig vekst i arbeidsproduktivitet.

- Kun en av endringene er signifikante på fem prosentnivå; det er økningen for nærings-, drikkevare- og tobakksindustrien.

- Økningen for bearbeiding og konservering av fisk mv., jordbruk, jakt og viltstell og næringsmidler med $6 \%$ sjømat, er signifikante på ti prosentnivå.

Tabellen viser for sammenligning av tiårsperiodene 1998-2007 og 20082017 at:

- De seks øverste sektorene har signifikant lavere gjennomsnittlig vekst i siste tiårsperiode sammenlignet med foregående periode. Dette gjelder de tre handelssektorene akvakultur, samlet industri, samt fiske, fangst og akvakultur.

- Bearbeiding og konservering av fisk mv. har en signifikant nedgang på ti prosentnivå 


\title{
Priser og marginer i verdikjeden for matvarer
}

\author{
Ivar Pettersen
}

Norsk institutt for bioøkonomi - NIBIO

\begin{abstract}
Food prices are higher in Norway than in neighbouring EU-countries like Sweden and Denmark. This article aims to understand the sources of price differences, i.e. where in the food value chain and the regulatory environment extra costs and margins originate. The analysis performed applies both data on the effects of import protection for national raw material prices, data on industry subsidies and duties and comparative price differentials in other, comparable sectors for fast moving consumer goods. In the second part of the article, accounts statistics are used to compare gross margins of value added between Norway, Denmark and Sweden on average. The results indicate differences in margin levels between the countries and, in particular, shifts in differences over time. Results show that the main contributor to a growing price margin for food between Norway and the average of Sweden and Denmark is increasing value of import protection for agricultural production, while gross margins at grocery retail level seem to reduce the price differential to the benefit of Norwegian consumers. The study also reveals weaknesses in the available statistics, and suggests avenues for improved analysis based on accounts statistics.
\end{abstract}

Keywords: food supply chain, vertical price analysis, food market policies, price surveillance, competition policy

Sitering av denne artikkelen: Pettersen, I. (2020). Priser og marginer i verdikjeden for matvarer. I F. Steen \& I. Pettersen (Red.), Mot bedre vitende i norsk matsektor (Kap. 4, s. 124-157). Oslo: Cappelen Damm Akademisk.

https://doi.org/10.23865/noasp.93.ch4

Lisens: CC BY-ND 4.0. 


\section{Introduksjon}

I denne artikkelen fordeler vi prisforskjeller for matvarer mellom Norge og gjennomsnitt for Sverige Danmark på forklaringsfaktorer og ledd i verdikjeden for matvarer. Vi bruker to tilnærminger. Først viser vi betydningen av forskjeller i merverdisatser, skjermingsstøtte dvs. importvernet - til jordbruket og observerte prisforskjeller i andre konsumvaremarkeder enn for matvarer. Analysen viser mulige forklaringer på noe av prisforskjellen mellom Norge og nabolandene, og resulterer i et stort og voksende uforklart restledd. Mest tydelig er endringen i relativ prisforskjell for matvarer og andre lett omsettelige konsumvarer som sko og klær. For sistnevnte er prisforskjellen forsvunnet over de senere år, mens den er økende for matvarer. Den uforklarte prisforskjellen øker kraftig.

I den andre delen av analysen bruker vi regnskapsdata til å se om prisforskjellen, spesielt endringer i prisforskjellen, kan tilskrives bruttomarginer på industri-, engros- og detaljistleddet. Vi begrenser oss til forhold som dreier seg om forskjeller bl.a. i bearbeidingsverdier, som andel samlet omsetning ut over jordbruksråvarer. Analysen viser hvordan samlet omsetningsverdi regnet ut fra norske og svenske/danske pris- og marginforhold fordeler seg på de enkelte leddene i verdikjeden. Analysen viser at endringer i prosentvise, relative bruttomarginer tilsier at matindustri og engroshandel har bidratt noe til økende matprisulempe for norske husholdninger, mens detaljistleddet har hatt motsatt effekt. Skjermingsstøtten til jordbruket har de siste syv årene gitt det største enkeltbidraget til $ø$ kte prisforskjeller.

Også den regnskapsbaserte analysen viser et voksende, uforklart restledd. Forklaringsfaktorer som ikke inngår i beregningen, er mulige forskjeller i importpriser for matvarer, eller andre prisforskjeller for innsatsvarer og -tjenester på industrileddet. Det hefter usikkerhet ved metode og datagrunnlag, dels på grunn av mangler og inkonsistenser i statistikkgrunnlaget, dels fordi beregningene er komplekse, og atter andre at bransjedefinisjoner og -avgrensninger i statistikken ikke gir mulighet for å følge en klart definert verdikjede eller et bestemt vareutvalg fra «jord til bord». I en relativt kortfattet artikkel er det vanskelig å gjøre fullstendig 
rede for alle regneoperasjoner. Vi har derfor lagt vekt på å få fram prinsippene i beregningen. Resultatene bør brukes med forsiktighet. Etter vår vurdering gir analysen likevel indikasjoner om viktige endringer over tid. Analysen avdekker også muligheter, og ikke minst behov, for å styrke og videreutvikle både statistikkgrunnlag og metode.

Det kan være endringer i norske verdikjeder eller i verdikjedene i Sverige eller Danmark som trekker prisnivåforskjellene mellom Norge og nabolandene i ugunstig retning for norske forbrukere. Slike mulige forklaringer blir ikke drøftet her. Fordeling av prisforskjeller på mulige forklaringsfaktorer og ledd i verdikjeden, gir i seg selv ingen forklaring på prisforskjeller. Artikkelen skal bidra til å lede oppmerksomheten mot de viktigste faktorene. På de fleste områder gjenstår drøfting av årsaker.

\section{Prisforskjeller mellom Norge og EU-land: Nivå og enkeltfaktorer}

Undersøkelser og analyser av prisutvikling for matvarer varierer både når det gjelder innhold og dokumentasjon (NOU 2011:4; Oslo Economics, 2015). I EU har arbeidet med oppfølgingen av dagligvaresektoren i stor grad dreid seg om å overvåke pristransmisjon, dvs. forholdet mellom prisindekser på ulike ledd i verdikjeden for matvarer over tid (EU/ High Level Forum, 2014). Dagligvarehandel og mat 2011 publiserte en sammenligning av prisnivået på matvarer i Norge, Sverige og Danmark (Pettersen, Kjuus \& Lavik, 2011). Senere er arbeidet oppdatert og videreutviklet med støtte først og fremst fra Forskningsmidlene for jordbruk og matindustri og også i en viss grad fra NorgesGruppen.

Vår erfaring er at det finnes lite forskning som benytter regnskapsdata for å belyse prisforskjeller for sektorer og hele verdikjeder. Usikkerhet og kompleksitet kan være en forklaring. De vertikale prisanalysene som ble gjennomført tidlig på 2000-tallet i Norge, forsøkte derfor å følge spesifikke varer fra råvareledd til butikkhylle (se f.eks. Bergset, Svennerud, 
Pettersen \& Kjuus, 2008; Strøm et al., 1999). Mye av litteraturen om prisdannelsen i det norske matvaremarkedet er også preget av spørsmålet om maktforhold og fordeling av overskudd mellom leddene i verdikjeden (Gabrielsen, Steen, Sørgard \& Vagstad, 2013). Det er mye teori, og relativt begrenset med empirisk belegg.

Første del av artikkelen tar utgangspunkt i norsk matvarekonsum, og viser prisforskjellene regnet i euro. Deretter ser vi på tre forklaringsfaktorer; generelt kostnadsnivå for distribusjon av forbruksvarer, skjermingen av jordbruket og matindustriens nettosubsidier.

\section{Matvareforbruk: Fra 20 til nær 10 prosent av husholdningenes forbruk}

Analysen tar utgangspunkt i verdien av norsk forbruk av matvarer og alkoholfrie drikkevarer. Ved hjelp av relative prisindekser for denne konsumgruppen, beregnes samlet verdiforskjell regnet i norske kontra gjennomsnittet av svenske og danske priser.

Figur 1 viser utviklingen i verdien av det norske forbruket av ulike varegrupper. Den velkjente trenden med fallende andel for mat- og drikkevarer og økende andeler for annet, ikke spesifisert konsum, er tydelig både regnet i løpende og faste 2015-priser. Matvarer og alkoholfrie drikkevarer har mer enn halvert andelen av samlet forbruk i husholdningene siden 1970. Det er liten forskjell på andel regnet i løpende og faste priser, dvs. det er mengden matvarer vi konsumerer som har vokst mindre enn mengden av andre konsumgoder. Prisutviklingen for matvarer er om lag som for konsum generelt. Bildet samsvarer godt med undersøkelser som viser at etterspørselen etter matvarer i liten grad øker med økte inntektsnivåer. Matvarer og alkoholfrie drikkevarer er imidlertid en bred varegruppe. Som vi vil vise har prisutviklingen vært ulik for ulike deler av varegruppen. Det betyr at forholdet mellom utvikling i mengde og verdi har variert innenfor varegruppen. 


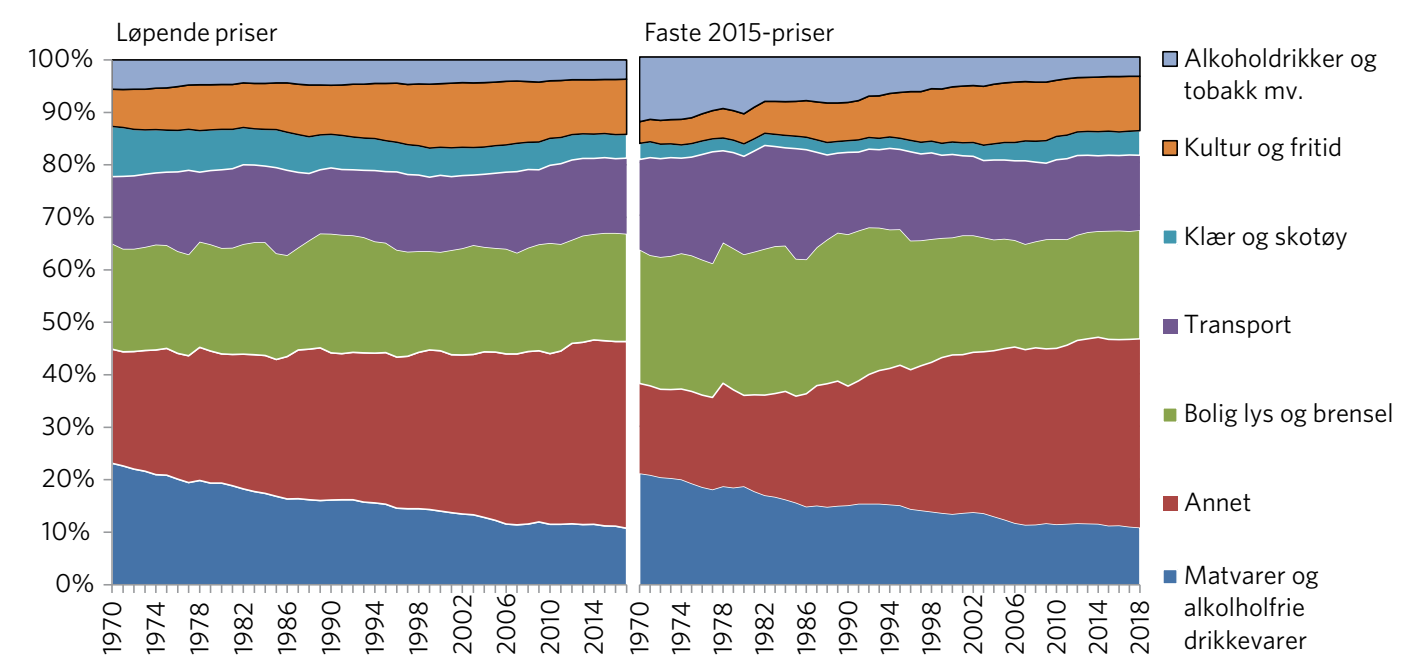

Figur 1 Norsk konsum i husholdninger fordelt på kategorier av forbruk. Løpende og faste priser. 1970-2018. Kilde: SSB, nasjonalregnskap.

\section{Matprisnivået i Norge, nabolandene og EU}

Relative kjøpekraftspariteter måler prisforskjeller mellom land inkludert avgifter som merverdiavgift (mva) og andre produktavgifter og subsidier. Figur 2 viser prisnivået på matvarer og alkoholfrie drikkevarer i Norge og utvalgte EU-land sammenlignet med gjennomsnittlig prisnivå i EU28 for årene 2003-2018. Forskjellen mellom Norge og EU varierer bl.a. med valutakurser. Det meste av perioden har norske priser på matvarer og alkoholfrie drikkevarer ligget 60 prosent over gjennomsnittsnivået for EU, men har i enkelte år vært 80 prosent høyere. Fra å øke frem til 2013, har forskjellen falt siden. Danmark ligger nærmest av de nordiske landene, men har i dag også ti prosentpoeng høyere matmoms enn Norge, mens matmomsen i Sverige ligger stabilt på 12 prosent. Sverige ligger mer enn 40 prosentpoeng lavere enn Norge i $2018\left(\mathrm{EU}_{28}=100\right)$. For vår analyse er det grunn til å merke seg endringen i danske og svenske relative matvarepriser etter 2015. Prisforskjellen mellom Norge og Sverige/Danmark øker markant i denne perioden, noe som gjenspeiles i våre videre analyser. 


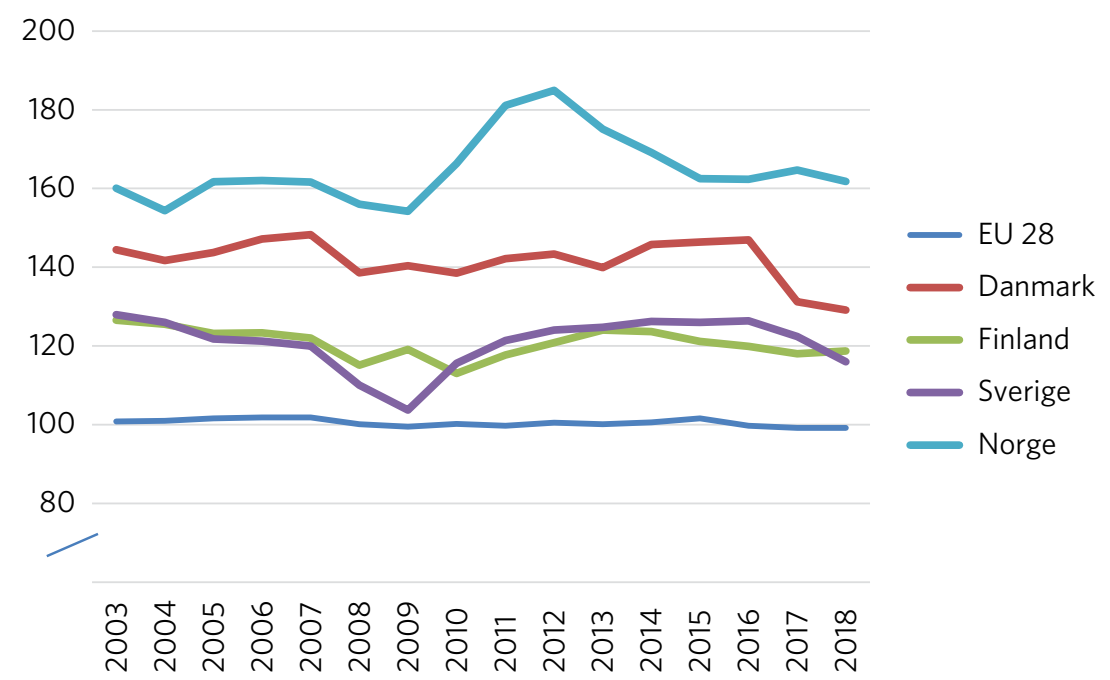

Figur 2 Relative kjøpekraftspariteter på mat- og alkoholfrie drikkevarer i et utvalg europeiske land, 2003-2018. Indeks EU27=100 i 2019. Prisnivåindeks inkl. merverdi avgift. Kilde: Eurostat, 2019.

Det er betydelig variasjon mellom matvaregrupper. Det norske relative prisnivået er høyest for andre matvarer, alkoholfrie drikkevarer og meieriprodukter inklusive egg. Sammenlignet med Sverige og Danmark er de norske meieriproduktene relativt mest kostbare. Prisforskjellen for kjøttvarer, frukt og grønt er om lag seksti prosent lavere enn for meieriproduktene. Prisforskjellen sammenlignet med EU er bare seks prosent for fisk, en varegruppe som er ti prosent billigere i Norge enn i våre naboland i 2018 (figur 3). At andre matvarer har høyt prisnivå sammenlignet med EU, kan skyldes at dette er varer som har høy grad av bearbeiding og som gjennomgår mange bearbeidingsledd. Samtidig skal den såkalte $\mathrm{RÅK}$-ordningen sørge for at det nettopp for disse varene er konkurranse mellom bearbeiding i Norge og EU, noe som skulle bidratt til å redusere prisforskjellen for disse varene (Gaasland, 2020). Det er også i denne varegruppen vi kan anta at det finnes en del eksempler på tollfri matvareimport. Når vi finner at importvernet er en sentral forklaringsfaktor for å forstå prisforskjeller, kan det altså være grunn til å se om en nærmere analyse av gruppene andre matvarer og alkoholfrie drikkevarer kan nyansere dette inntrykket. 


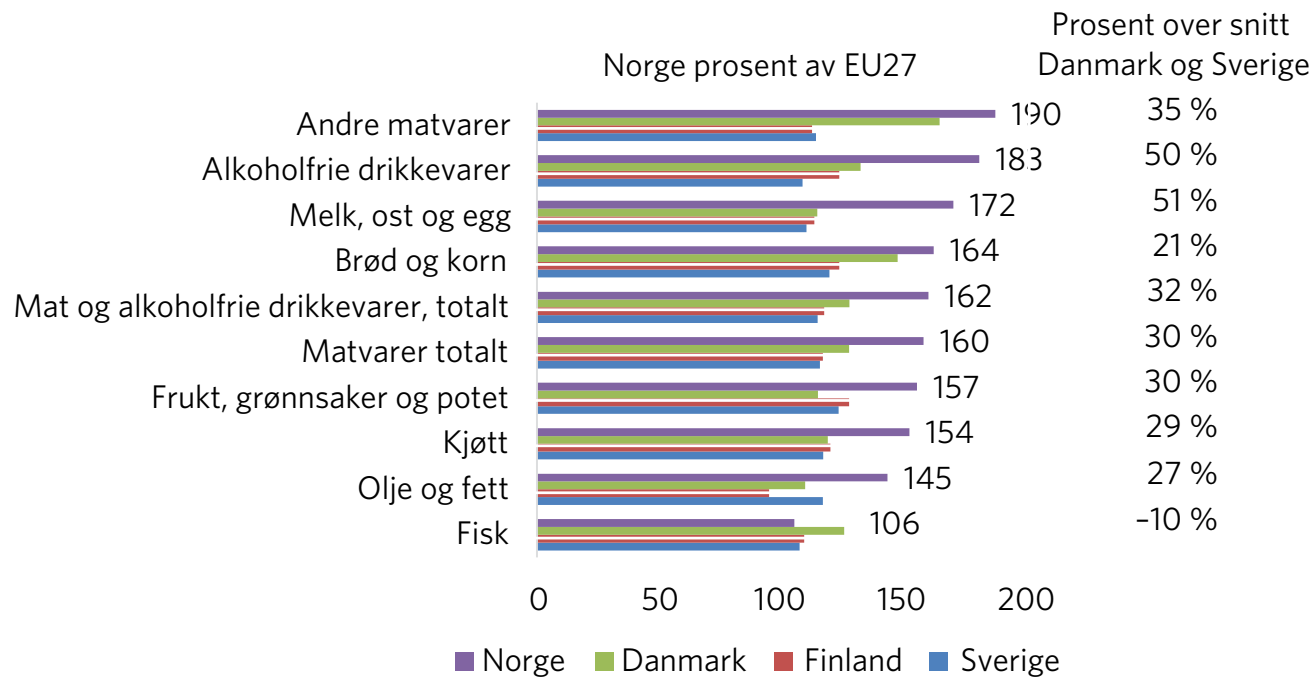

Figur 3 Relative kjøpekraftspariteter på et utvalg matvarer i et utvalg europeiske land. Indeks EU27 =100, 2018. Prisnivåindeks inkl. mva. Kilde: Eurostat.

Figur 3 viser også at variasjon i relative prisforskjeller ikke er særegent for Norge. Av figuren fremgår det f.eks. at snittet for Sverige og Danmark for fisk ligger 18 prosent over prisnivået for EU27 (lik 1,06/o,9), mens prisnivået for andre matvarer, meierivarer og kjøtt ligger hhv. 41, 14 og 19 prosent over nivået for EU27. Også for Sverige og Danmark er det andre matvarer som skiller seg sterkest ut.

Ulike matvarer har hatt ulik utvikling over tid. Figur 4 viser at seks av åtte matvaregrupper hadde høyere prisdifferanse til snitt for Sverige og Danmark i 2018 enn i 2005, mens to kategorier ligger lavere; sjømat og kjøtt. Avstanden til den diagonale linjen i figuren viser størrelsen på endringen. Alkoholfrie drikkevarer har femdoblet differansen, fra 10 til 50 prosent. For frukt og grønnsaker, andre matvarer og brød og kornvarer er differansen omkring doblet. Meierivarer og egg hadde størst prisdifferanse i 2005. Differansen er siden økt, og har dermed fortsatt høyest prisdifferanse i 2018. 
Differanse 2018, prosent

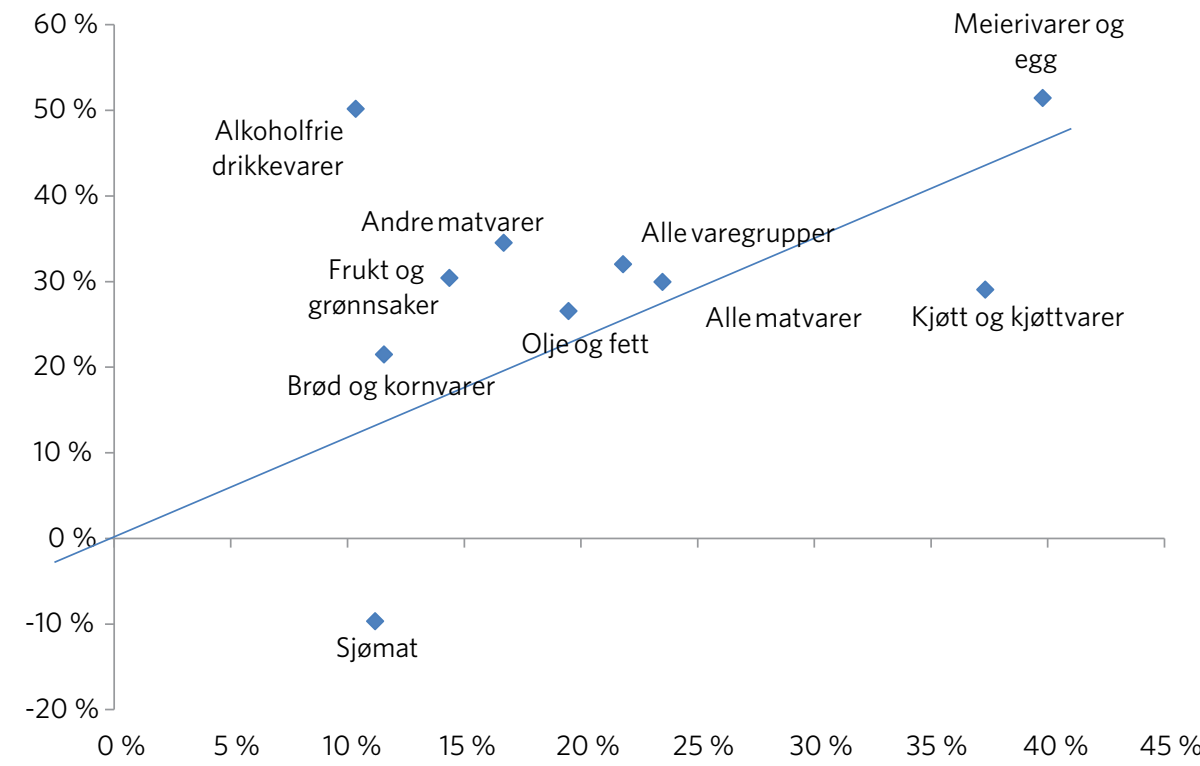

Differanse i prosent, 2005

Figur 4 Prisforskjeller for kategorier matvarer i 2005 og 2018; norske priser sammenlignet med snitt Sverige og Danmark. Prisnivåindekser inkl. mva. Kilde: Eurostat.

\section{«Generell kostnadsulempe» er forsvunnet}

Det er ikke bare prisnivået på matvarer og alkoholfrie drikkevarer som er høyere i Norge enn i EU-landene. I 2018 lå det generelle konsumprisnivået, inklusive matvarer, 55 prosent høyere i Norge enn gjennomsnittet i EU28. Det er bare litt lavere enn prisforskjellen for mat og alkoholfrie drikkevarer på 63 prosent. Sterke bidragsytere er de typiske særavgiftsvarene tobakk og alkoholholdige drikkevarer, men figur 5 viser at også typiske lett omsettelige konsumvarer som klær og skotøy har markert høyere prisnivå i Norge enn i EU; henholdsvis 28 og 31 prosent (figur 5). Når vi i det følgende bruker klær og skotøy som sammenligning, er det 
både fordi vi sammenligner lett omsettelige konsumvarer, og fordi en sammenligning med klær og skotøy er en sammenligning med varer som nærmest utelukkende er importerte. I tillegg har endringer i tollsatser osv. ingen betydning i den perioden vi ser på. Det er også små forskjeller i momssatser mellom de nordiske landene. Vi får altså et uttrykk for en merkostnad primært i distribusjon.

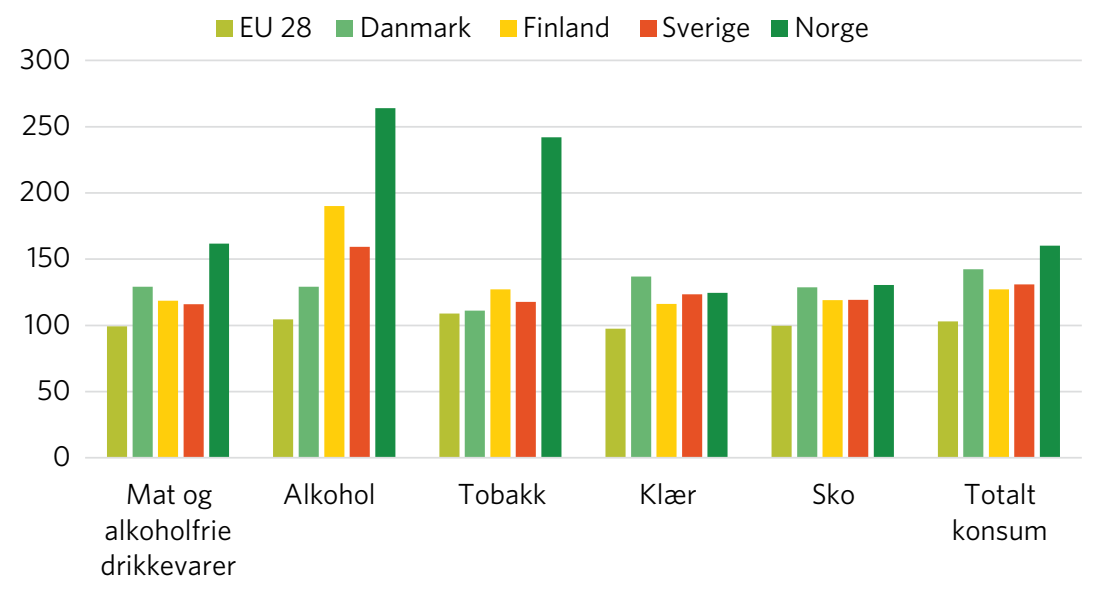

Figur 5 Prisnivåindekser for grupper av varer og tjenester i Norge, EU28, Danmark, Finland og Sverige i 2018. Indeks EU27=100 i 2019. Inkl. mva. Kilde: Eurostat, 2019.

Varegruppene har hatt ulik utvikling sammenlignet med nabolandene. Sammenligner vi norske priser med gjennomsnittet for Sverige og Danmark, ser vi at norske priser for mat og alkoholfrie drikkevarer har steget fra 22 til 32 prosent over svensk/dansk prisnivå, mens prisforskjellen for klær og skotøy har sunket fra 22 prosent til minus en prosent (figur 6). Med andre ord, både i 2005 og 2010 kunne man antyde at vi hadde en «generell kostnadsulempe», en merkostnad som man kunne anse som relativt normal, i distribusjon av lett omsettelige konsumvarer, og at denne kostnadsulempen kunne forklare en stor del av prisforskjellen overfor nabolandene i matsektoren (Pettersen et al., 2011). Slik er det ikke lenger. Merprisen for disse andre konsumvarene er snudd til en liten fordel for Norge. At vi samtidig får kraftig økning i uforklart forskjell, reiser spørsmål om det er forhold innenfor matverdikjeden som er vesentlig 
endret; men det kan også være slik at klær og skotøy har gjennomgått en spesiell utvikling som gjør disse mindre relevante for sammenligning. En årsak kan være økt netthandel. Forskjellen mellom de to konsumvaresektorene er i så fall verdt å studere nærmere.

Endringen $\mathrm{i}$ kronekursen mot euro og dermed også mot danske og svenske kroner, spiller en rolle. Svekkelsen av norske kroner etter oljeprisfallet $i$ 2014 skulle imidlertid virket i motsatt retning enn det vi observerer. Mens matvarepriser i stor grad er en funksjon av rene nasjonale forhold som jordbruksoppgjør osv., og dermed skulle ha en fordel av svekket kronekurs, er prisene på klær og skotøy nær 100 prosent basert på import, hvor svekket kronekurs ikke skulle hatt betydning for prissammenligningen i euro. ${ }^{1}$

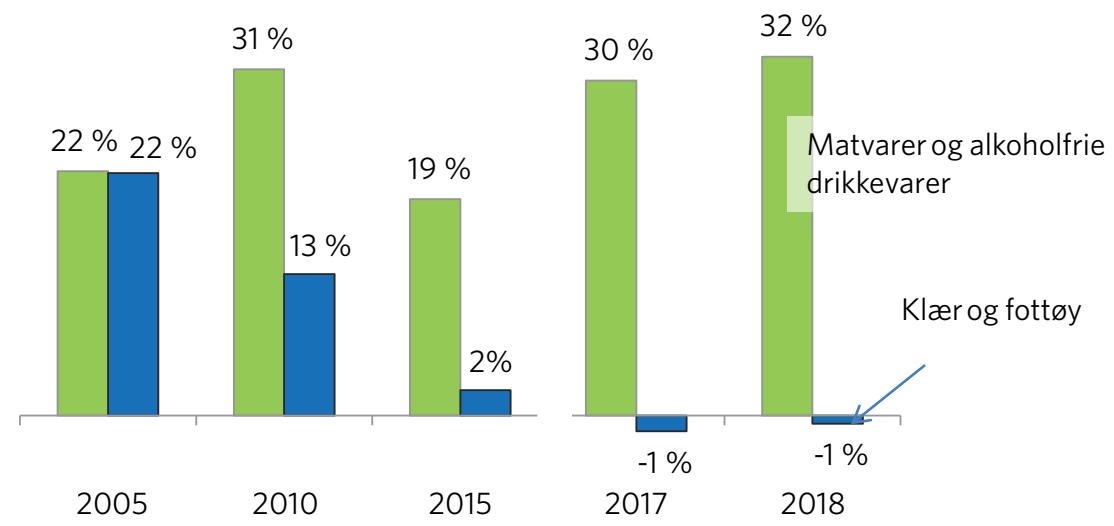

Matvarer og alkoholfrie drikkevarer. Prisdifferanse sammenlignet med EU27.

$\begin{array}{llllll}\text { Danmark-Sverige } & 31 \% & 27 \% & 34 \% & 28 \% & 24 \% \\ \text { Norge } & 59 \% & 66 \% & 60 \% & 66 \% & 63 \%\end{array}$

Figur 6 Norske prisnivåer sammenlignet med snitt i Sverige og Danmark. Prisnivådifferanser i euro i prosent. 2005-2017, utvalgte år. Matvarer og alkoholfrie drikkevarer og klær og skotøy. Nederst: Prisdifferanser for snitt Danmark/Sverige og Norge, i prosent, sammenlignet med EU27 for matvarer og alkoholfrie drikkevarer. Kilde: Eurostat.

1 Det kan være forskjeller i importvernet for sko og klær i Norge og EU, men i vår analyse er det eventuelle endringer i det relative importvernet som skulle hatt betydning. Vi kjenner ikke til slike endringer i den perioden vi drøfter her. Endringer i importvernet for matvarer er imidlertid en viktig del av analysen i resten av artikkelen. 
Den voksende prisforskjellen for matvarer mellom Norge og gjennomsnitt for Sverige og Danmark henger sammen med at det svensk/danske prisnivået har nærmet seg gjennomsnittet for EU, mens norsk prisnivå altså er steget relativt til EU (se tallene nederst i figur 6). Norges prisforskjell overfor EU er økt med fire prosentpoeng, mens den er sunket med syv prosentpoeng for Sverige og Danmark i perioden 2005-2018. Siden vi kun ser på relative prisnivåer, er det viktig å være klar over at figur 6 tyder på forklaringen til endringene relative prisforhold i større grad kan ligge i nabolandene enn i Norge.

\section{Skjermingsstøtten til jordbruket varierer, med stigende trend}

Skjermingsstøtten til det norske jordbruket viser hvor mye av tollsatsene i importvernet som utnyttes til å ta ut høyere priser på jordbruksråvarer i Norge enn i verdensmarkedet. ${ }^{2}$ Figur 7 viser produksjonsverdien i jordbruket i Norge og EU fordelt på verdi regnet til internasjonale priser, skjermingsstøtte og støtte over statsbudsjettet (budsjettstøtte). Skjermingsstøtten til norsk jordbruk er økt siden år 2000, men sank mer enn 20 prosent i løpende kroner fra 2015 til 2017, dvs. i den perioden kronekursen falt. Fallet i kronekursen har, alt annet like, ført til en oppskrivning av verdien av jordbruksproduksjonen vurdert til verdensmarkedspriser, og dermed reduksjon i utmålt skjermingsstøtte. For EU-jordbruket er skjermingsstøtten redusert med om lag to tredeler fra 2000, men den økte noe i løpende euro fra 2015 til 2017.

2 Skjermingsstøtten er definert som forskjellen mellom innenlandsk produsentpris og en referansepris multiplisert med produsert mengde. Referanseprisen er et uttrykk for verdensmarkedsprisen. Det norske importvernet og betydningen av dette er nærmere drøftet i Gaasland (2011, 2020). 
Markedsverdi ekskl. skjermingsstøtte $\square$ Pris-(skjermings-)støtte $\square$ Budsjettstøtte

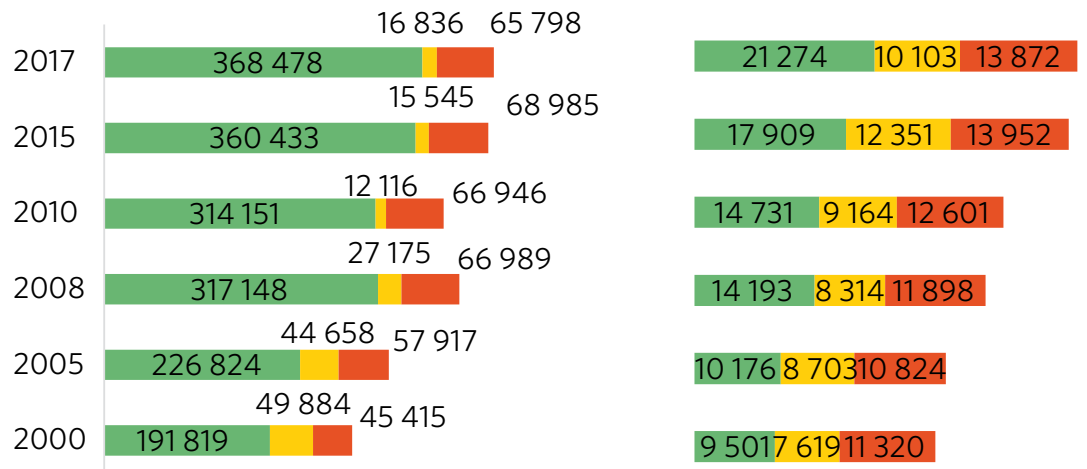

Figur $\mathbf{7}$ Internasjonal markedsverdi av norsk produksjon og EU-produksjon av jordbruksprodukter, skjermingsstøtte og budsjettstøtte. 2000, 2005, 2010, 2015 og 2017. Løpende priser, euro for EU og norske kroner for Norge. Kilde: OECD (2019) og egne beregninger.

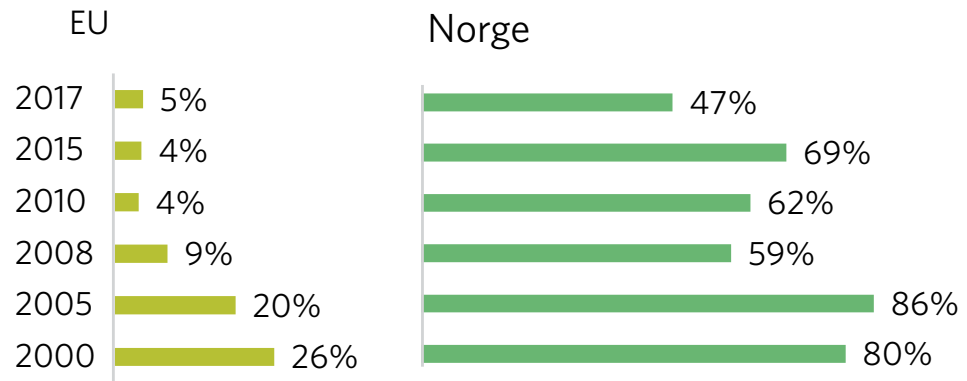

Figur 8 Skjermingsstøtte i prosent av verdi regnet til internasjonale priser. EU og Norge, 2000, 2005, 2010, 2015 og 2017. Kilde: OECD (2019) og egne beregninger.

For sammenligningen med nabolandene bruker vi støttenivåt i EU, siden Sverige og Danmark er del av EUs indre marked for jordbruksvarer. Selv om tollvernet er det samme, finnes det betydelige prisforskjeller for matvarer innad i EU. Statistikken gir ikke grunnlag for å skille mellom prisforskjeller som skyldes importvern og prisforskjeller som skyldes naturlige handelshindringer, preferanser for nasjonalt produserte 
matvarer osv. (jf. Gaasland, 2020). Mange av disse forholdene påvirker prisnivået både for norske og svensk/danske primærprodusenter. Dersom prisene til primærprodusentene i Danmark og Sverige ligger merkbart over prisnivået i EU, og norske primærprodusenter har en naturlig, ikke politisk bestemt, prisfordel sammenlignet med verdensmarkedet, vil vi i analysen overdrive betydningen av importvernet for den observerte prisforskjellen mellom Norge og nabolandene.

I analysen bruker vi EUs skjermingsstøtte i prosent av verdensmarkedsverdier for sammenligning med norsk skjermingsstøtte (figur 8). Det betyr at vi antar at skjermingsstøtten i 2017 vil utgjøre 5 prosent av internasjonal markedsverdi i Sverige og Danmark mot 47 prosent for Norge. Forskjellen på 42, ned fra 65 prosent i 2005, utgjør 8,9 milliarder kroner av en total produksjonsverdi på 21,27 milliarder kroner i 2017. Skjermingsstøtten i Norge er altså om lag ti ganger høyere enn i EU, og mens EU har fjernet 80 prosent av skjermingsstøtten, har Norge fjernet vel 40 prosent, alt regnet i prosent av produksjonsverdi til verdensmarkedspriser.

\section{Matindustriens netto næringssubsidie}

Norsk nærings- og nytelsesmiddelindustri er pålagt et mangfold av avgifter og nyter samtidig godt av subsidier (Rålm, 2014). Avgiftene kan deles i negative og positive produkt- og næringsavgifter. Særavgiftene ble

\section{Håndtering av avgifter og tilskudd}

I analysen bruker vi tilskudds- og avgiftsberegningen i nasjonalregnskapet. Bearbeidingsmarginene vi regner med er regnet til basispriser som er eksklusive næringsavgifter og subsidier. Vi bruker differansen mellom bearbeidingsverdi i basispriser og faktorpriser som estimat for netto næringsavgifter.

Ut fra de undersøkelsene vi har gjort, er subsidiene som er ført på matindustrien de senere årene først og fremst arbeidsmarkedstiltak fra kommune, fylkeskommune eller stat. Næringsavgiftene dreier seg om motorvognavgifter og f.eks. utslippsavgifter. Føringen av den beregnede nettosubsidien blir dermed negativ korreksjonspost til beregnet bearbeidingsverdi til basispris når det gjelder å forklare prisforskjell mellom Norge og nabolandene. 
grundig drøftet i NOU 2007:8, og sukkervare- og sjokoladeavgiften igjen i NOU 2019:8. Rålm fant at samlede avgifter på nærings- og nytelsesmiddelindustrien utgjorde vel 24 milliarder kroner i 2013 (Rålm, 2014, op.cit. tabell 3.2). Av dette regnet han med at ca. 80 prosent gjaldt produktavgifter for tobakk og alkoholholdige drikkevarer. I forbindelse med budsjettet for 2018 ble avgiften på sjokolade- og sukkervarer og avgiften på alkoholfrie drikkevarer økt med henholdsvis 80 og 40 prosent.

Vi har ikke oppdatert denne beregningen, først og fremst fordi det er krevende å sammenligne avgiftsstatistikk mellom land. Nasjonalregnskapet gir imidlertid holdepunkter for å identifisere en undergruppe av avgiftene og subsidiene. I nasjonalregnskapet på næringsnivå oppgis bruttoprodukt i basispriser og faktorpriser. Basispriser vil si netto for inngående og eksklusive utgående produktavgifter. Moms er ikke medregnet. Faktorpriser inkluderer næringsstøtte og tar hensyn til ikke-produktrettede næringsavgifter. Forskjellen mellom basis- og faktorpris er netto næringsstøtte, dvs. den nettoen som bidrar til å øke betalingsevnen for arbeidskraft og kapitalinnsats. Det er netto næringsstøtte vi her vil måle og sammenligne mellom land.

Figur 9 viser beregnede netto næringsavgifter for produksjon av matvarer og alkoholfrie drikkevarer for Norge, Sverige og Danmark: Prosent av bruttoprodukt til basisverdi til venstre, og omregnet til løpende euro til høyre. Matindustrien har en nettoavgift på ti prosent i Sverige, en nettosubsidie på 2 prosent i Norge, og tilnærmet nøytral næringsavgift i Danmark (se forklaring i boks).

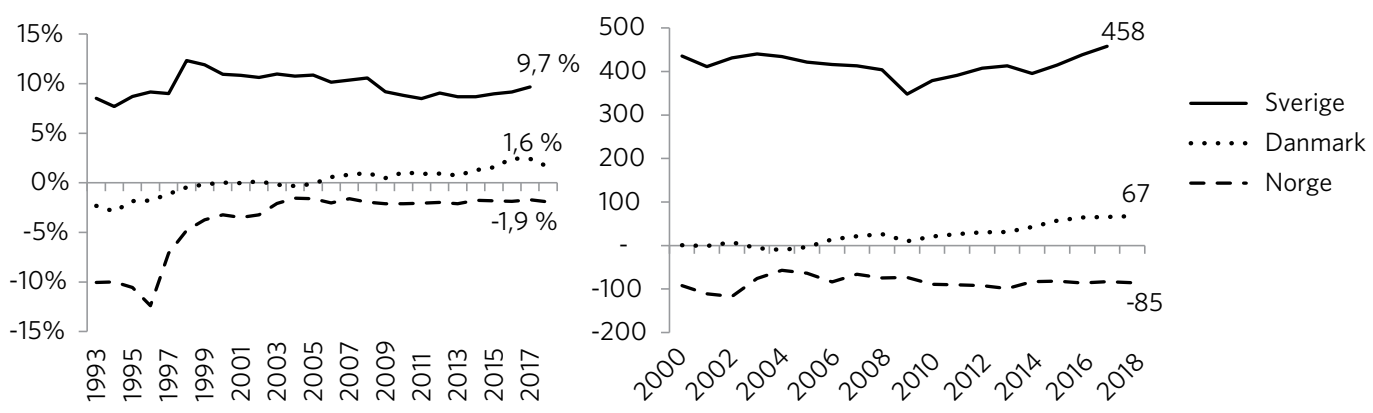

Figur 9 Netto næringsavgifter for produksjon av matvarer og alkoholfrie drikkevarer i Danmark, Norge og Sverige. Venstre del: Prosent av bruttoprodukt til basispriser 1993-2018. Høyre del: absolutte tall, dvs. omregnet til løpende euro. 2000-2018. Kilde: Nasjonalregnskapsstatistikk for Danmark, Norge og Sverige. Danmarks statistikk, SSB og SCB. 


\section{Prisforskjell fordelt på enkeltfaktorer}

Med utgangspunkt i tallene ovenfor og forskjeller i merverdisatser, kan vi gi en grov illustrasjon av elementene bak prisforskjellen på matvarer mellom Norge og våre naboland. Vi måler prisforskjellen ut fra et valgt mål for samlet konsum av matvarer, og fordeler deretter forskjellen på bidrag fra ulike merverdiavgifter, skjermingsstøtte til jordbruket osv.

Samlet forbruk i Norge av matvarer og alkoholfrie drikkevarer er i vår analyse regnet som samlet forbruk i husholdninger, som SSB beregner til 154 milliarder kroner i 2017 (jf. figur 1). Forskjellen i husholdningenes utlegg regnet til norske og svensk/danske priser vil ut fra de beregnede prisforskjellene være lik 22,31 og 30 prosent i henholdsvis 2005, 2010 og 2017. Tabell 1 (jf. figur 6) viser forskjell i både prosent og kroner. De som handler matvarer og alkoholfrie drikkevarer i Norge, antas altså å betale 30 prosent mer i 2017 enn gjennomsnitt for handling i Sverige og Danmark med samme handlekurv. Dette merutlegget utgjør ca. 35,5 milliarder kroner.

Tabell 1 Forskjell i utlegg til matvarer og alkoholfrie drikkevarer med norsk kontra svensk/dansk prisnivå. Norske husholdninger. Prosent og millioner kroner. Utvalgte år. Kilde: SSB forbrukstall i nasjonalregenskapet og Eurostats prisindekser.

\begin{tabular}{|l|r|r|r|r|r|r|}
\hline & $\mathbf{2 0 0 5}$ & $\mathbf{2 0 0 8}$ & $\mathbf{2 0 1 0}$ & $\mathbf{2 0 1 5}$ & $\mathbf{2 0 1 7}$ & $\mathbf{2 0 1 8}$ \\
\hline Prosent & $22 \%$ & $26 \%$ & $31 \%$ & $19 \%$ & $30 \%$ & $32 \%$ \\
\hline NOK, mill. & 18009 & 23067 & 29031 & 23988 & 35534 & 38477 \\
\hline
\end{tabular}

Tallene i tabell 1 gir grunn til refleksjon, både over trenden, men kanskje like mye over variasjonen, over tid. Som vist i figur 2 var 2015 et år med historisk lave priser for Norge og tilsvarende høye for Danmark, relativt til prisnivået for EU under ett. Det er god grunn til å være forsiktig når vi tolker data for enkeltår.

I figur 10 setter vi sammen enkeltfaktorene som er gjennomgått ovenfor og viser hvor mye av den samlede prisforskjellen som kan forklares. Av en samlet prisforskjell i 2017 på 35,5 milliarder kroner, er det største enkeltbidraget skjermingsstøtten, dvs. importvernet. Vi omtaler enkeltfaktorene nærmere nedenfor. Figuren har imidlertid ett enkelt hovedbudskap: Forskjellen var i 2005 knyttet til de faktorene vi har beregnet, først og fremst det vi kunne regne som en naturlig merkostnad, men er i 2017 
i all hovedsak uforklart. Endringen er primært skjedd fra 2015-2017, altså i en periode hvor prisutviklingen i Danmark har vært spesielt forskjellig fra norsk prisutvikling (jf. figur 2), og hvor kronekursen overfor snittkurs for svenske og danske kroner er svekket. Fra 2015 har alle enkeltfaktorer redusert sine bidrag til å forklare prisforskjellen. Uforklart rest er vesentlig økt. Resultatet gir dermed god grunn til å forsøke å bryte ned også restleddet ved å se på marginene i verdikjeden.

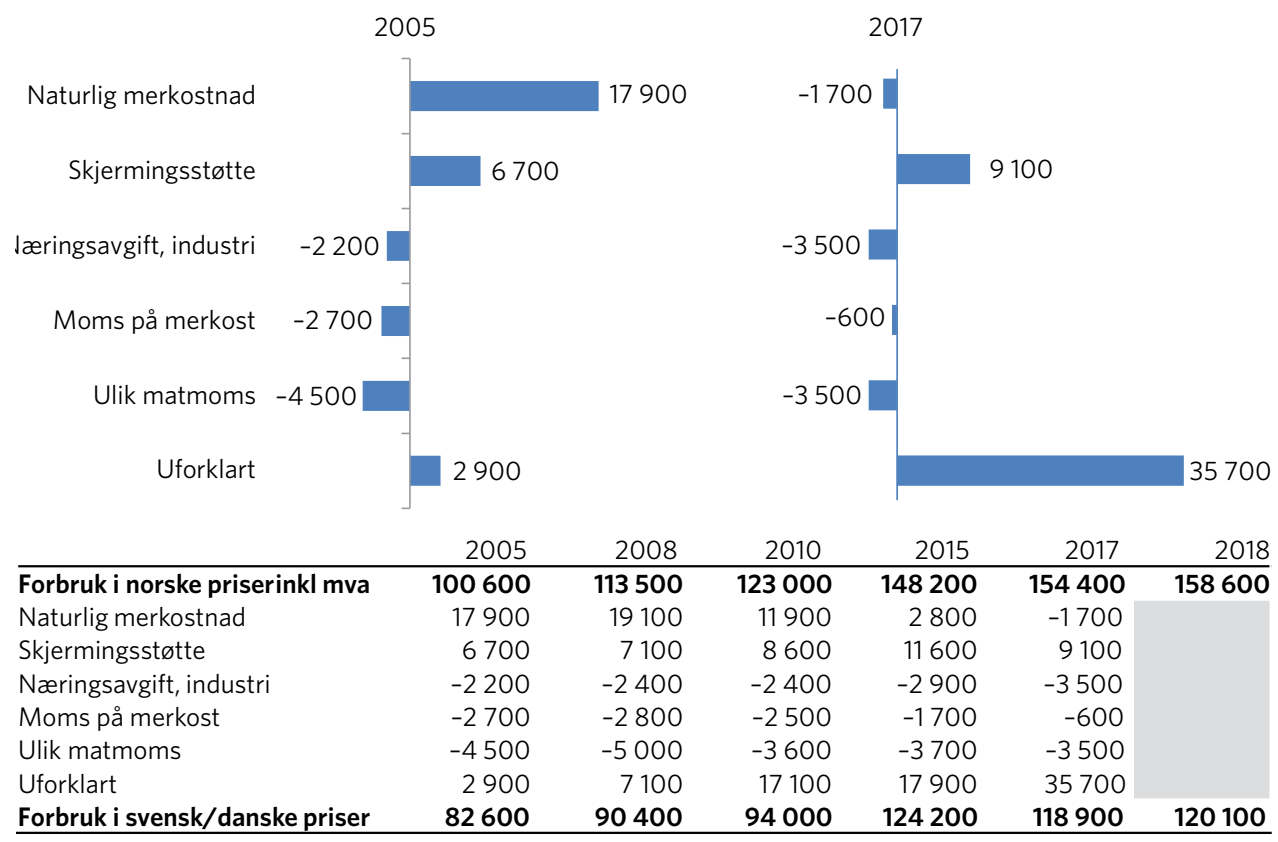

Figur 10 Differanse mellom de norske husholdningenes forbruk av matvarer og alkoholfrie drikkevarer i norske og gjennomsnitt for svenske og danske matvarepriser, nedbryting av differanse på fem mulige forklaringsfaktorer og en uforklart rest. Kilder: Eurostat, OECD, nasjonalregnskapsstatistikk for Norge (SSB), Sverige (SCB) og Danmark (Danmarks statistikk).

Beregningen av både enkeltfaktorer og prisgap er usikker. Sammenligning mellom år, dvs. endring, er mer pålitelig enn sammenligning av nivåer på enkeltfaktorer på ett tidspunkt. Men logikken i regnestykket er enkel: skjermingsstøtten vil, per definisjon, bidra til å øke prisnivået på førsteleddet. Videre vil momsen ha to effekter. Den ene er at norsk matmoms på 15 prosent i 2017 demper differansen mellom norske og 
gjennomsnittet av svenske og danske priser med vel tre prosent. I tillegg må merkostnadene på de faktorene vi har identifisert, tillegges moms. Differansen mellom næringsstøtte til norsk matindustri og tilsvarende for snittet av svensk og dansk, demper det relative prisnivået for Norge, for gitte driftsresultater og gitt effektivitet for øvrig.

Den naturlige merkostnaden har, som nevnt ovenfor, en intuitiv forklaring: Det virker rimelig å legge til grunn at distribusjon av matvarer og alkoholholdige drikkevarer vil ha en merkostnad sammenlignet med andre land, om man også observerer slike merkostnader for annen norsk distribusjon av lett omsettelige forbruksvarer. Merkostnaden kan ha flere mulige årsaker, som alminnelig kostnadsnivå for arbeidskraft og transport, butikkstruktur m.m., som er hovedtema i Pettersen, Steen og Ulsaker (2020). Grunnen til at den generelle kostnadsulempen som vi ser i andre konsumvaresektorer er forsvunnet, kan tenkes å ha med ulik grad av alternativer til tradisjonell distribusjon å gjøre, som netthandel, noe som foreløpig ikke har vært like fremtredende for matsektoren. I denne artikkelen har vi, som nevnt, ikke kunnet drøfte slike mulige forklaringer nærmere.

\section{Regnskapsbasert fordeling av marginer i verdikjeden}

I dette avsnittet bruker vi norsk og internasjonal regnskapsstatistikk for å fordele prisdifferansen på ulike ledd i verdikjeden. Mens vi så på enkeltfaktorer på tvers av aktører og ledd i verdikjeden i forrige avsnitt, analyser vi her enkeltleddene etter primærleddet. I stedet for å bruke en naturlig pris- og kostnadsforskjell som skal gjenspeile det generelle forholdet mellom produksjons- og distribusjonskostnader i Norge og nabolandene, forsøker vi å indikere forskjeller i bruttomarginer direkte. Metoden fordeler om lag halvparten av forskjellen i norsk matvareforbruk regnet til norske kontra gjennomsnitt av svenske og danske priser. Regnestykket viser en ganske stabil fordeling av forskjellen mellom de ulike leddene i Norge. Når det gjelder økningen i samlet prisforskjell mellom Norge og nabolandene fra 2008/2010 til 2015/2017, bidrar alle ledd utenom detaljistleddet til økt forskjell. Den største veksten i den norske prisulempen ligger i skjermingsstøtten, dvs. i importvernet for primærleddet og økt relativ 
matmoms, mens utviklingen i detaljistleddets prosentvise bruttomarginer har bidratt til å redusere prisulempen over de syv årene. Beregningen er kompleks, og resultatene må brukes med forsiktighet.

\section{Metode, datakilder og begreper}

Metoden beskrives stegvis i punktene nedenfor:

1. Forbruk til norsk og svensk/dansk prisnivå: Utgangspunktet er også her verdien av forbruk av matvarer og alkoholfrie drikkevarer regnet til norske priser, basert på nasjonalregnskapets forbruk i husholdninger (jf. tabelldelen i figur 10). Omregning til svenske og danske priser skjer også her ved Eurostats prisindekser for forbruk av matvarer og alkoholfrie drikkevarer omregnet til samme valuta (jf. tabell 1).

2. Primoerleddet: Markedsverdien av norsk produksjon av jordbruksvarer regnet til internasjonale priser finnes i OECDs statistikk for produsentstøtte i ulike land (jf. figur 7). Det er de samme internasjonale prisene som ligger til grunn for beregnet markedsverdi for norskproduserte og EU-produserte varer på primærleddet. Beregningen av skjermingsstøtten til jordbruket er forklart ovenfor, og utgjør priseffekten for norske råvarer av tollvernet mot import av jordbruksprodukter. Skjermingsstøtten i prosent av markedsverdien av jordbruksråvarer i Norge og for EU som helhet benyttes til å beregne skjermingsstøtte som andel av norsk forbruksverdi ved henholdsvis norske og svensk/danske rammebetingelser (jf. figur 8).

3. Matindustrileddet: Bearbeidingsverdi for matindustrien er beregnet som bruttoprodukt regnet i faktorpriser, dvs. inklusive næringssubsidier og avgifter. For beregning av forskjell mellom norsk og svensk/dansk matindustri bruker vi de prosentvise bearbeidingsverdiene regnet i prosent av omsetning på detaljistleddet, justert for effekten av eksport og eksportrettet sjømatindustri³ . Ved å bruke 
omsetningen på detaljistleddet som nevner i beregning av prosentvise marginer, begrenser vi virkningen av bransjeintern handel. Forskjellen i beregnet bearbeidingsverdi for norsk kontra svensk og dansk matindustri er således forskjellen mellom norsk og gjennomsnittlig svensk/dansk bearbeidingsverdi i prosent multiplisert med omsetning på detaljistleddet i Norge, regnet til norske og, alternativt, svensk/danske priser. Den differansen vi måler er altså effekten av ulike bearbeidingsverdier regnet i prosent av omsetning med henholdsvis norske og svensk/danske priser. Kilden til de prosentvise bearbeidingsverdiene er Eurostats foretaksstatistikk.

4. Distribusjonsleddene: Bruttomargin på henholdsvis engros- og detaljistledd er beregnet som bruttomarginer i prosent av omsetning. ${ }^{4}$ Kilden er også her Eurostats foretaksstatistikk. Den viktigste forskjellen mellom beregningen for industri- og handelsleddene er at vi bruker henholdsvis bearbeidingsverdi for førstnevnte og bruttomargin for de sistnevnte leddene. ${ }^{5}$ Dette betyr at vi inkluderer forbruk av varer og tjenester ut over forbrukte råvarer til foredling i marginberegningen på distribusjonsleddene, men ikke på industrileddet. Dvs. at analysen tar hensyn til en større del av kostnadsmassen på handelsleddene enn på industrileddet.

5. Annen, ufordelt ressursbruk i verdikjeden: Annen ressursbruk eller forbruk i verdikjeden er en residual. Typiske kostnadselementer som inngår her, vil være importerte matvarer regnet til importverdi med toll, prisforskjeller på norskproduserte mat- og drikkevarer som ikke er tollbeskyttet, samt alle kostnader til forbruk av varer og tjenester i matindustrien, ut over norskproduserte jordbruksvarer. Som nevnt regner vi med kun bearbeidingsverdien

4 Engrosleddet omfatter engroshandel med bredt vareutvalg med hovedvekt på matvarer og engroshandel med frukt og grønnsaker. Detaljistleddet består av detaljhandel med bredt vareutvalg med hovedvekt på matvarer. For Danmark må vi bruke en noe bredere næringsklasse av detaljutsalg med bredt vareutvalg generelt.

5 Når vi i artikkelen bruker begrepet margin, skyldes det språkbruken i internasjonal statistikk for varehandel hvor "gross margin» oversettes til bruttomargin. På norsk vil bruttoavanse brukes om samme. Margin og bearbeidingsverdier er altså ikke lønnsomhetstall; de inneholder kostnader til ansatte og kapital. Bruttomargin inneholder i tillegg til bearbeidingsverdien også kostnader til forbrukte varer og tjenester. 
på industrileddet, mens vi regner hele bruttomarginen i handelsleddene, dvs. inklusive forbruk av varer og tjenester.

6. Merverdiavgift: Konsekvensen av ulik merverdiavgift er beregnet som merverdiavgift med norsk og gjennomsnittlig svensk/dansk matmomssats for forbruksverdi regnet til henholdsvis norske og svensk/danske priser.

7. Hull i tallmaterialet: For enkelte variabler og år har det vært nødvendig å erstatte manglende tall med trendbaserte tall, dvs. med estimerte tall basert på lineære regresjoner.

Beregningen er også beskrevet i tabell 2.

Tabell 2 Fordeling langs verdikjeden av verdiforskjell for matvareforbruk regnet til norske og svensk/danske priser. Oversikt over beregningen. Fotskrift s betyr: beregnet på data for snitt Sverige og Danmark. Variabler uten fotskrift er beregnet med norske data.

\begin{tabular}{|c|c|c|c|c|c|}
\hline & Tegn & \multicolumn{2}{|c|}{ Verdi til norske priser } & \multicolumn{2}{|c|}{$\begin{array}{r}\text { Verdi av norsk forbruk regnet } \\
\text { til svensk/danske priser }\end{array}$} \\
\hline $\begin{array}{l}\text { Verdi av } \\
\text { jordbruksproduksjon til } \\
\text { internasjonale priser }\end{array}$ & $A$ & \multicolumn{2}{|c|}{ Fra OECDs PSE-database } & \multicolumn{2}{|l|}{ A (forutsatt lik for alle land) } \\
\hline Skjermingsstøtte & $\mathrm{B}$ & \multicolumn{2}{|c|}{ Fra OECDs PSE-database } & \multicolumn{2}{|l|}{$\left(B_{s} / A_{s}\right) * A$} \\
\hline $\begin{array}{l}\text { Bearbeidingsverdi, } \\
\text { industri }\end{array}$ & C & \multicolumn{2}{|c|}{$(K / I)^{\star}(H /(1+J))$} & \multicolumn{2}{|l|}{$\left(\mathrm{K}_{\mathrm{s}} / \mathrm{I}_{\mathrm{s}}\right)^{\star}\left(\mathrm{H}_{\mathrm{s}} /\left(1+\mathrm{J}_{\mathrm{s}}\right)\right)$} \\
\hline $\begin{array}{l}\text { Bruttomargin, } \\
\text { engrosleddet }\end{array}$ & $D$ & \multicolumn{2}{|c|}{$(L / I)^{\star}(H /(1+J))$} & \multicolumn{2}{|l|}{$\left(\mathrm{L}_{\mathrm{s}} / \mathrm{I}_{\mathrm{s}}\right)^{\star}\left(\mathrm{H}_{\mathrm{s}} /\left(1+\mathrm{J}_{\mathrm{s}}\right)\right)$} \\
\hline $\begin{array}{l}\text { Bruttomargin, } \\
\text { detaljistleddet }\end{array}$ & $E$ & \multicolumn{2}{|c|}{$(M / I)^{\star}(H /(1+J))$} & \multicolumn{2}{|l|}{$\left(M_{s} / I_{s}\right)^{\star}\left(H_{s} /\left(1+J_{s}\right)\right)$} \\
\hline $\begin{array}{l}\text { Annet merforbruk i } \\
\text { verdikjeden }\end{array}$ & $F$ & \multicolumn{2}{|c|}{$F=H-A-B-C-D-E$} & \multicolumn{2}{|l|}{$F_{s}=H_{s}-A_{s}-B_{s}-C_{s}-D_{s}-E_{s}$} \\
\hline Merverdiavgift & G & \multicolumn{2}{|c|}{$G=(A+B+C+D+E+F)^{\star} J$} & \multicolumn{2}{|c|}{$G_{s}=\left(A_{s}+B_{s}+C_{s}+D_{s}+E_{s}+F_{s}\right)^{\star} J_{s}$} \\
\hline $\begin{array}{l}\text { Verdi av forbruk av } \\
\text { mat- og alkoholfrie } \\
\text { drikkevarer }\end{array}$ & $\mathrm{H}$ & \multicolumn{2}{|c|}{$\begin{array}{l}\text { Hentet fra norsk statistikk, } \\
\text { og pr. def. } \\
\mathrm{H}=\mathrm{A}+\mathrm{B}+\mathrm{C}+\mathrm{D}+\mathrm{E}+\mathrm{F}+\mathrm{G}\end{array}$} & \multicolumn{2}{|c|}{$\begin{array}{l}H_{s}=H / p, p r \text {. def. } \\
H / p=A+B_{s}+C_{s}+D_{s}+E_{s}+F_{s}+G_{s}\end{array}$} \\
\hline \multicolumn{6}{|l|}{ Hjelpevariabler } \\
\hline \multicolumn{2}{|c|}{$\begin{array}{l}\text { Omsetning på detaljistleddet, } \\
\text { netto for mva. }\end{array}$} & I & \multicolumn{2}{|c|}{ Bruttomargin engroshandel } & $L$ \\
\hline \multicolumn{2}{|l|}{ Mva-sats, matvarer } & $J$ & \multicolumn{2}{|c|}{ Bruttomargin detaljhandel } & $M$ \\
\hline \multicolumn{2}{|c|}{ Bearbeidingsverdi, industri } & $\mathrm{K}$ & \multicolumn{2}{|c|}{$\begin{array}{l}\text { Relativ prisindeks for mat og alkoholfrie } \\
\text { drikkevarer; Norge / snitt Sverige og Danmark }\end{array}$} & $p$ \\
\hline
\end{tabular}




\section{Fordeling av forbruksverdi ved norske og svensk/ danske priser; nivåer og endringer}

Figur 11 viser forbruksverdi av matvarer i Norge, beregnet med norske priser og priser som gjenspeiler gjennomsnittet for Sverige og Danmark. Regnemåten er som beskrevet i tabell 2. Forbruksverdien er regnet som gjennomsnitt for to år og fordelt på seks elementer, herunder tre ledd i verdikjeden. For Norge viser figuren fordelingen med syv års mellomrom. Sammenligningen mellom Norge og gjennomsnitt for Sverige og Danmark gjelder snitt for 2015 og 2017.

Den prosentvise fordelingen langs den norske verdikjeden er ganske stabil over tid, men med økende andel for merverdiavgift, matmomsen er økt, og for markedsverdi av jordbruksproduksjonen regnet til internasjonale priser. Andelen for bruttomarginen i detaljhandelen faller mest, fra 15 til 13 prosent. Også andelen for skjermingsstøtte og annet forbruk i verdikjeden er redusert. Øvrige andeler er konstante. Det er mer markante forskjeller mellom den norske og svensk/danske verdikjeden.

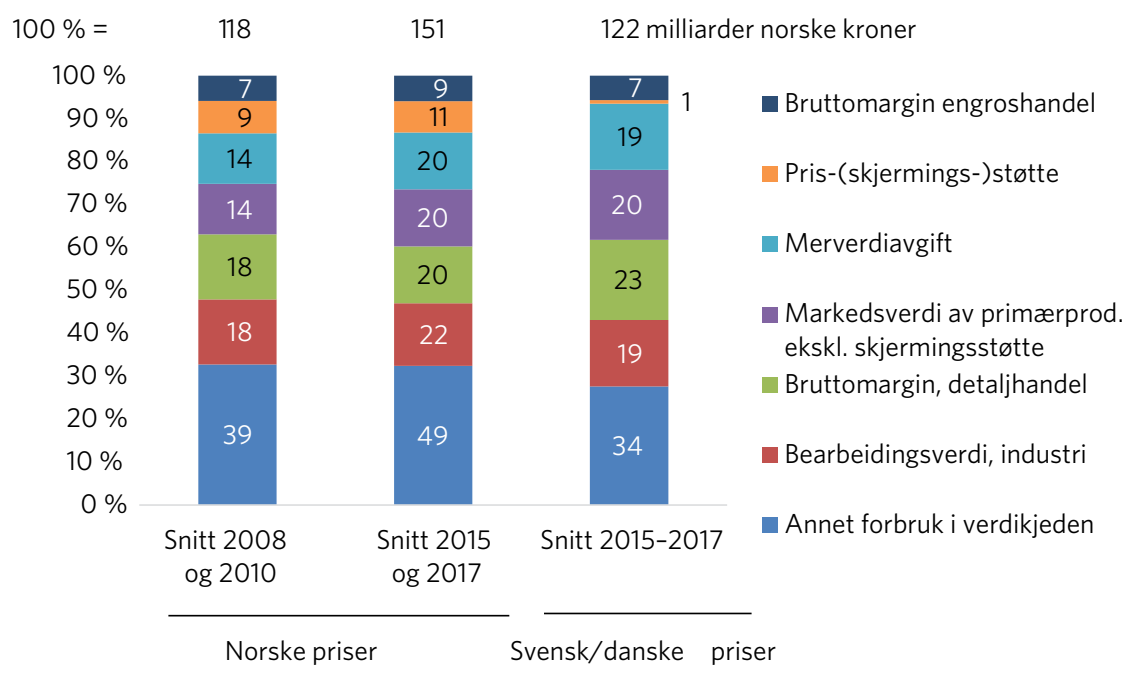

Figur 11 Verdi av forbruk av matvarer og alkoholfrie drikkevarer fordelt på enkeltledd i verdikjeden og ufordelt, annet forbruk i verdikjeden. Verdi i norske priser for snitt 2008 og 2010 sammenlignet med snitt 2015 og 2017, samt verdi i svensk/danske priser, snitt 2015 og 2017. 
Norge skiller seg fra gjennomsnittet av Sverige og Danmark ved lavere andeler for detaljhandel, merverdiavgift og markedsverdi av jordbruksproduksjon til internasjonale priser (i figuren: «Markedsverdi ekskl. skjermingsstøtte»). Bruttomarginen på detaljistleddet kommer ut med lavere prosentandel og lavere absolutt verdi for Norge enn for Sverige. Dette reflekterer betydelig lavere beregnet norsk bruttomargin i prosent av omsetningen på detaljistleddet. Av differansen på detaljistleddet på tre milliarder til fordel for lavere norsk prisnivå, motsvarer merkostnaden på engrosleddet to milliarder kroner. Forskjellen på industrileddet, som altså bare omfatter bearbeidingsverdiene, dvs. en mindre andel av kostnadsmassen på dette leddet enn på handelsleddet, er på tre milliarder som bidrar til høyere relativt norsk prisnivå. Andelen for bruttomargin i engroshandelen er også høyere i Norge enn i Sverige og Danmark. Engroshandelen bidrar med anslagsvis to milliarder til prisnivåforskjellen mellom Norge og Sverige/Danmark.

Andelen for uspesifisert, annet forbruk i verdikjeden, dvs. residualen i beregningen, er vesentlig lavere for Sverige og Danmark enn for Norge, mens skjermingsstøtten er så godt som uten betydning i våre naboland. Residualen utgjør også kostnader som fordeler seg gjennom verdikjeden. Som nevnt er det mer begrenset mulighet for at posten inngår i distribusjonsleddene enn i industrileddet. Siden skjermingsstøtten måler fulle prisforskjeller på primærleddet, er det trolig først og fremst andre kostnader på industrileddet og eventuelle prisforskjeller for importerte matvarer som kan forklare denne ufordelte merkostnaden.

Figur 11 viste altså ganske stabile andeler over tid i Norge. Figuren sammenlignet også Norge og gjennomsnitt for Sverige og Danmark i 2015 og 2017. Vi har også regnet på forskjellene for Norge sammenlignet med Sverige og Danmark for de enkelte ledd, ved starten og ved slutten av syvårsperioden. Når vi sammenligner disse forskjellene, får vi frem et bilde av hvilke ledd og faktorer som bidrar til eller demper økningen i prisforskjell mellom Norge og nabolandene. Utviklingen i differansene på de enkelte ledd kan indikere om det er enkelte ledd som synes å utvikle seg mer eller mindre ufordelaktig for forbrukere i Norge sammenlignet med Sverige og Danmark. 


\section{Markedsverdi ekskl. skjermingsstøtte \\ Pris-(skjermings-)støtte \\ Bearbeidingsverdi, industri \\ Bruttomargin engroshandel \\ Bruttomargin, detaljhandel \\ Annet forbruk i verdikjeden \\ Merverdiavgift \\ Konsum av matvarer og ikke- \\ alkoholholdige drikkeverar}

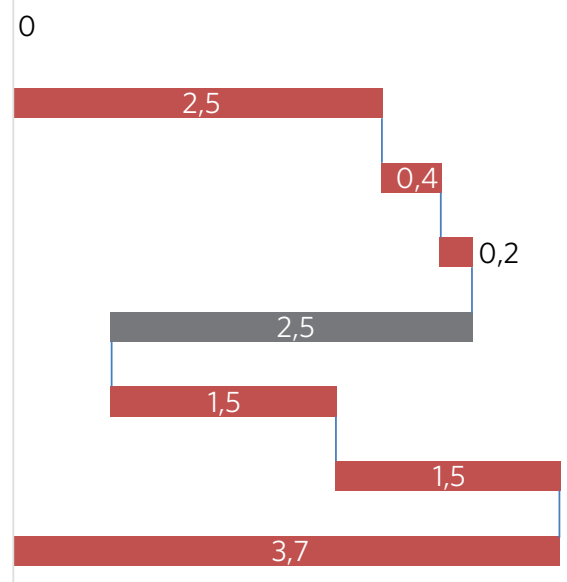

Figur 12 Differanse mellom norsk forbruk av matvarer og alkoholfrie drikkevarer regnet i norske kontra svensk/danske priser. Endring fra 2008/10 til 2015/17 fordelt på enkeltledd i verdikjeden, merverdiavgift og annet, ufordelt forbruk i verdikjeden.

Figur 12 viser derfor om norsk importvern, industri eller handel, over de siste syv årene, bidrar til å øke eller redusere prisulempen overfor våre naboland i EU. Figuren tar utgangspunkt $i$ at differansen mellom forbruk av matvarer og alkoholfrie matvarer er økt med ca. 3,7 milliarder kroner fra snitt 2008/2010 til snitt 2015/2017. Figuren viser hvilke elementer som har bidratt til denne endringen.

Det er tre store enkeltbidrag, samt en vesentlig motpost. De tre enkeltbidragene kommer først og fremst fra skjermingsstøtten til jordbruket, som har økt sitt bidrag til samlet prisforskjell med 2,5 milliarder kroner. I tillegg har annet, ufordelt forbruk i verdikjeden økt med 1,5 milliarder kroner. Det samme har bidraget fra merverdiavgiften grunnet økt matmoms i Norge. Bruttomarginen i detaljhandelen har, sammenlignet med en situasjon med uendrede relative, prosentvise bruttomarginer, redusert den samlede prisforskjellen med 2,5 milliarder kroner. 


\section{Hovedfunn, diskusjon og implikasjoner}

Analysen har seks hovedfunn: (1) Forskjellen i prisnivå for matvarer og alkoholfrie drikkevarer har vært moderat, men øker. (2) Skjermingsstøtten til jordbruket utgjør en betydelig og økende del av den samlede prisulempen på mellomlang sikt. (3) Dagligvarehandelen har, basert på sammenligning av prosentvise bruttomarginer, samlet sett ingen stor effekt på prisulempen i 2015/2017, men har over de siste syv årene redusert forskjellen mellom norsk og svensk/dansk prisnivå. (4) Bidragene fra henholdsvis engrosledd og detaljistledd har motsatt fortegn og ulik absolutt verdi; førstnevnte øker prisforskjellen, sistnevnte reduserer den og mer enn kompenserer for bidraget fra engrosleddet. (5) Bearbeidingsverdien i matindustrien bidrar moderat til økte prisforskjeller. (6) Økningen i prisdifferansen kan ikke forklares med valutakurseffekter. Her drøftes hvert av hovedfunnene før en avsluttende kommentar om implikasjoner av funn og metodevalg.

\section{Moderat, men økende prisforskjell}

Som vist i figur 6 har prisforskjellen mellom Norge og våre naboland, over tid, ligget noe over 20 prosent og steget til vel 30 prosent. Tabell 1 viser et betydelig avvik for 2015 sammenlignet med 2010 og 2017, som er kommentert ovenfor, men for øvrig er andelen i hovedsak gradvis $ø$ kende. Den beregnede forskjellen utgjør om lag to prosent av samlet forbruk i norske husholdninger.

Merkostnaden for norske forbrukere er betydelig, og fordelingen av merkostnaden kan være sosialt lite bærekraftig. Men i et historisk perspektiv er merkostnaden relativt moderat. Som vist i figur 6 var merkostnaden for norske matkonsum rundt 2005-2010 om lag prosentvis som for konsumvarer som klær og skotøy. Vi har også vist at forskjellen i prisnivå, vis-à-vis EU, også er stor for konsumvarer generelt. Dvs. det var ingen ekstraordinær situasjon i matsektoren, tross importvernet. 
At ikke utviklingen de senere årene, med synkende norsk krone, har redusert forskjellen, gir grunn til bekymring. Men bildet av årsaksforholdene har noen klare trekk. Vi har i løpet av syvårsperioden fått sterkere landbrukspolitisk prioritering av prisvirkemidler. Vi har trolig også hatt en relativt ugunstig prisutvikling for importerte matvarer eller anskaffelser av andre varer og tjenester til industrien. Det siste er faktorer som fortjener en mer selvstendig analyse. Vi har også fått økende matmoms.

\section{Skjermingsstøtten til jordbruket gir voksende prisforskjell}

Den økende relative verdien av skjermingsstøtten til jordbruket betyr økte prisgap for jordbruksråvarer mellom Norge og utlandet. Som vist i figurene 7 og 8 ser vi en endret tendens fra 2015-2017.

Den mer langsiktige økningen i skjermingen har trolig konsekvenser ut over selve priseffekten for norske konsumenter og råvareprisutviklingen for industrien. En konsekvens kan være at industrien får sterkere motiver for å erstatte norske matråvarer med andre innsatsvarer, spesielt innsatsvarer som kan importeres tollfritt. En slik effekt kan bidra til at det ufordelte merforbruket i verdikjeden øker, slik vi ser i analysen. Dersom f.eks. norske jordbruksråvarer erstattes av importerte syntetiske næringsmidler som følge av ekstra høyt importvern og relativt høye priser på jordbruksbaserte råvarer, vil forbruket av innsatsvarer drives opp sammenlignet med forbruket i våre naboland. Slikt merforbruk inngår her i restleddet for annet forbruk i verdikjeden.

En annen effekt er at det blir vanskeligere å sikre balanse i markedet, fordi mulighetene for eksport av råvarer svekkes. Fallhøyden og risikoen ved overproduksjon øker med store prisforskjeller, mens det ikke kan brukes tilskudd for å redusere prisen for eksport av produktoverskuddet. Dette vil igjen bidra til økte kostnader i en industri som i stor grad er eid av bøndene og har plikt til å motta de råvarene bøndene produserer (Asheim et al., 2019).

Det er også en sannsynlig sammenheng mellom konkurranse og importvern. Gaasland (2020) og Oslo Economics/Oeconomica (2017) viser at etableringsmulighetene for internasjonale dagligvareaktører blir 
svekket. Importvernet reduserer muligheten for å bruke internasjonale leverandørnettverk for internasjonale dagligvareaktører. Dermed må en utenlandsk kjede regne med relativt svake kjøpsbetingelser som liten aktør i en etableringsfase i det norske markedet.

Den økte skjermingsstøtten styrker grensehandelen, noe som demper merkostnaden for det norske matvareforbruket. De prisforskjellene vi har vist, tar ikke hensyn til effekt av grensehandel.

Den beregnede effekten av importvernet kan overdrive skjermingsstøttens betydning. Innledningsvis viste vi f.eks. at varegruppene med høyest relativt prisnivå, andre matvarer og alkoholfrie drikkevarer, er blant varegruppene hvor tollvernet er redusert eller fraværende. I tillegg kan, som nevnt, prisforskjeller mellom norske og internasjonale råvarer skyldes naturlige handelshindre og forbrukerpreferanser.

\section{Dagligvarehandelen har redusert prisforskjellen siste syv år}

Som vist i figur 11 har engros- og detaljistledd samlet sett noe lavere beregnet bruttomargin enn beregnet bruttomargin med svensk/ danske prosentvise marginer og svensk/dansk prisnivå. Vi finner altså ikke grunn til å hevde at ineffektivitet eller marginer i dagligvarehandelen bidrar til høye norske matvarepriser. Siden tallene for Danmark ikke er fullt ut sammenlignbare med Sverige og Norge, må vi imidlertid være forsiktig med bruken av de absolutte verdiene. I tillegg er det, som vist i figur 2, store endringer i relative prisnivåer for både Norge og Danmark i perioden $2015-2017$.

Det er grunn til å merke seg den indikerte forskjellen på grossist- og detaljistledd. Grossistleddet alene bidrar til økte prisdifferanser. Detaljistleddet demper prisforskjellen etter våre estimater. En forklaring kan være at merkostnaden i distribusjon til et mer spredt distribusjonsnett ligger på engros- og ikke detaljistleddet. En annen kan være forskjell i markedsmakt og lønnsomhet, som er blant årsakene vi ikke har drøftet. En tredje forklaringsfaktor kan være endring i arbeidsdelingen mellom enkeltledd i verdikjeden. Med økende andel egne merkevarer, nye systemer for logistikkstyring osv. (Pettersen, Steen \& Ulsaker, 2020), kan det være helt 
naturlig at det skjer forskyvning i marginer mellom leddene i dagligvarehandelen og mellom handel og industri. Både endringene i relative marginer og forskjeller i prisutvikling på engros- og detaljistledd, kan tyde på slike forskyvninger av arbeidsoppgaver fra detaljistledd til engrosledd. Begrenset sammenlignbarhet mellom tallene for detaljistleddet i Danmark og andre land i materialet skaper usikkerhet om nivåtallene, men i mindre grad om endringstallene de siste syv årene basert på snitt av to og to enkeltår. Våre tall indikerer at dagligvarehandelen totalt, over de siste syv årene, har gitt et vesentlig bidrag til å redusere prisforskjellene mellom Norge og gjennomsnittet av Sverige og Danmark. I vår regnemetode er årsaken at den prosentvise bruttomarginen både på detaljist- og engrosleddet har sunket sammenlignet med snittet for Sverige og Danmark. De danske prosentmarginene er også redusert, men det oppveies av økning i svenske marginer. Endringstallene er imidlertid følsomme for valg av år. I statistikken er det betydelig avvik mellom tallene for $2017 \mathrm{og}$ de to foregående årene. Oppdatering når 2018-tall foreligger, kan gi endringer i beregningene.

Normalt er det stor grunn til forsiktighet med analyser av engrosleddet. For det første viser vi bare konsekvensene av endringer i prosentvise bruttomarginer. Videre er prisutviklingen på mellomleddene vanskelig å dokumentere (Pettersen et al., 2020). En annen vesentlig kilde til usikkerhet gjelder bransjeinndelingen. I tidligere versjoner av pris- og marginanalysen har vi brukt tall for samlet engroshandel med næringsmidler, og fått resultater som var vanskelige å tolke. Her har vi kun regnet med engroshandel med bredt vareutvalg med hovedvekt på næringsmidler, som vi regner med primært dekker de landsdekkende grossistgrupperingene innenfor dagligvarehandelen, pluss engroshandel med frukt og grønt, som i Norge domineres av Bama-gruppen. Dermed har vi ikke med grossister som lever av eksport av sjømat eller spesialgrossister for smale grupper av næringsmidler. En siste grunn til forsiktighet er selve arbeidsdelingen mellom de to handelsleddene.

Detaljhandelen omfatter detaljhandel med bredt vareutvalg med hovedvekt på næringsmidler. Hoveddelen av denne næringsgruppen regner vi med består av supermarkedene. Detaljhandelskjeder med bredt vareutvalg uten hovedvekt på matvarer er i fremgang i Norge, men deres 
omsetning av matvarer er ikke medregnet i de beregnede bruttomarginene i handelen.

Et viktig usikkerhetsmoment ved sammenligningen mellom Norge og Sverige/ Danmark, er manglende statistikk for danske supermarkeder og noen hull i statistikken for enkeltår hvor vi må bruke trendberegninger. De bruttomarginene, regnet i prosent av omsetning, vi har benyttet for Danmark, er klart fallende over tid, slik at dansk detaljhandel isolert sett reduserer norsk dagligvarehandels dempende effekt for prisforskjellen.

Vi regner med hele bruttomarginen for dagligvarehandelen når vi skal forklare prisforskjellen for matvarer og alkoholfrie drikkevarer. Det overdriver mest sannsynlig effekten av dagligvareleddet, siden en vesentlig del av vareutvalget er andre varer enn næringsmidler. Dersom marginutviklingen for ulike deler av varesortimentet har vært sterkt varierende, vil en fordeling av bruttomarginen mellom næringsmidler og andre deler av vareutvalget gi andre resultater.

\section{Matindustrien står for liten del av økte prisforskjeller}

Matindustrien synes å ha høyere brutto bearbeidingsmarginer enn industrien i nabolandene, men er ingen vesentlig bidragsyter til de økte prisforskjellene mellom Norge og nabolandene over tid. Med økte differanser for bearbeidingsverdien for matindustrien på 0,4 milliarder, bidrar industrien til ca. ti prosent av økningen i samlet differanse over syv år, og mindre enn en femtedel av bidraget fra skjermingsstøtten.

Tolkningen av tallene bør ta hensyn til tre forhold: forskjellen mellom bearbeidingsverdi og bruttomargin, avgifter og subsidier og behandlingen av sjømatindustrien. Det er en betydelig del, kanskje 20-30 prosent, av kostnadsmassen ut over forbrukte råvarer, som ikke medregnes på industrileddet, til forskjell fra på handelsleddet. Dette er en av grunnene til at vi får en stor, ufordelt kostnadspost som vi her kaller annet forbruk i verdikjeden.

Det andre forholdet gjelder avgifter og subsidier. Når vi bruker bearbeidingsverdi til faktorpriser skal bearbeidingsverdien være beregnet netto for både produkt- og næringsavgifter og inklusive næringssubsidier og produktsubsidier. Vi regner altså med den verdien som 
tilfaller virksomhetenes egne innsatsfaktorer. Det beløpet som viser netto næringsavgifter i figur 9 er med andre ord inkludert i bearbeidingsverdien. Problemet med posten er imidlertid at det er vanskelig å kontrollere føringen og beregningen av netto-avgiftene. Det er f.eks. subsidier til kornsektoren, som prisnedskrivningstilskudd for korn og matkorntilskudd, som ifølge muntlige opplysninger fra SSB utbetales til markedsregulator Felleskjøpet og som føres som støtte til engrosleddet. Siden motposten til disse tilskuddene antagelig er noe høyere innkjøpspriser for korn fra bøndene, kan effekten på bearbeidingsverdi til faktorpriser være nøytral. Men siden vi regner med bruttomarginer i handelen, kan føringen av tilskuddene i Felleskjøpets regnskaper føre til undervurdering av bruttomarginer på engrosleddet. Et annet spørsmål er om støtten burde vært regnet til korn- og mølleindustrien, og ikke til engroshandel.

Produktavgifter for industrien, som sukkervareavgift osv., vil inngå som del av anskaffelsesprisene for engrosleddet uten å ligge inne i bearbeidingsverdien for industrileddet. Det betyr at produktavgiftene også blir en sannsynlig, betydelig bidragsyter til den ufordelte merkostnaden i verdikjeden. De betydelige særavgiftene for alkohol og tobakk ligger imidlertid utenfor beregningen.

Sjømatindustrien har betydning for gjennomsnittlige bearbeidingsverdier i matindustrien. Sjømatindustrien utgjør også vesentlig større andel av matindustrien enn det som gjenspeiler norsk matvarekonsum. Vi har derfor brukt tall for næringsmiddelindustri med en nedjustert andel sjømatindustri, hvor den andelen vi benytter gjenspeiler sjømatens andel av norsk matvareforbruk i kroner. Vi har også tatt ut industrisektoren produksjon av fôrvarer til husdyr, og inkludert kun mineralvannindustri og produksjon av øl blant drikkevarebransjene. For dansk og svensk matindustri har vi, som nevnt, redusert bearbeidingsverdiene med andelen eksport av bearbeidede matvarer. 


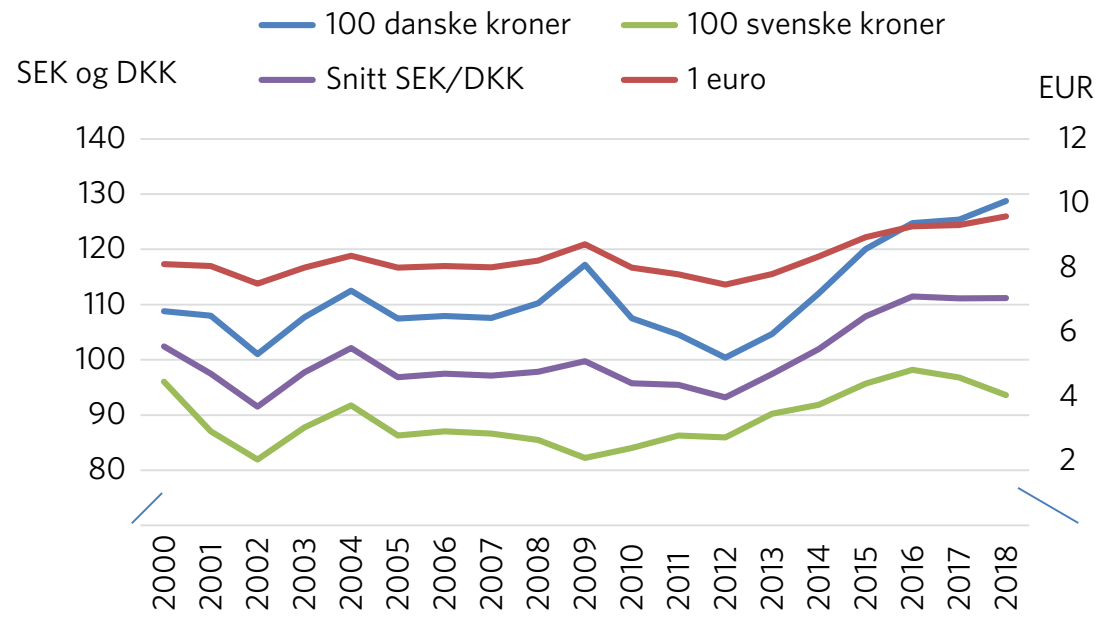

Figur 13 Valutakurser for svenske og danske kroner og euro, 2000-2018.

\section{Valutakurseffekter gir ingen forklaring}

Den generelle økningen i prisdifferansen kan ikke forklares med valutakurseffekter. Figur 13 viser at eurokursen i 2009 var på 8,73 og 2016 på 9,29, dvs. en kursstigning på ca. seks prosent. Stigningen for snitt svensk og dansk krone er noe større grunnet spesielt svak svensk krone i 2009. Det betyr at det norske kostnadsnivået omregnet til euro har hatt en vesentlig kostnadsreduserende effekt av valutakursendringene for perioden 2010-2017 under ett, med nøytral effekt etter 2016. Dersom hele det norske utlegget til matvarer og alkoholfrie drikkevarer var kronebasert og nominelt uendret, skulle valutakursen alene ha bidratt til en betydelig reduksjon i verdien av norsk forbruk, regnet i euro. I stedet har vi sett en $ø$ kning i merkostnaden på 3,7 milliarder.

\section{Mulige implikasjoner}

Analysen her gir grunn til å videreutvikle metoden og grunn til økt oppmerksomhet om noen enkeltfaktorer. Tilgjengelig statistikk gir mulighet for å belyse en større del av vareinnkjøpene ut over råvarene til industrien, og også for å belyse relativ prisutvikling for importerte matvarer i 
Norge og i våre naboland. Dermed kan det være mulig å forklare noe av det merforbruket i verdikjeden som utgjør sekkeposten, dvs. annet merforbruk i verdikjeden, i figur 11.

Våre analyser aktualiserer spørsmålet om hvorvidt norsk matindustri kan ha en betydelig kostnadsulempe både for importerte råvarer regnet før toll, og for kjøp av andre tjenester og forbruksvarer. Selv om statistikken for tollprovenyer er lite tilgjengelig, er det mulig å finne hvor mye betalte tollavgifter bidrar til prisforskjeller mellom Norge og våre naboland.

Statistikken gir mulighet til å skille ut driftsresultatene som forklaringsfaktor innenfor bruttomargin- eller bearbeidingsverdien, men vil i så fall aktualisere spørsmål om avgrensing av næringene ytterligere, f.eks. grensedragning mellom dagligvarehandel og eie og drift av forretningslokaler. Når vi bruker bruttomarginer i analysen, inkluderer vi også kostnader for leie av lokaler i marginberegningen for handelen, mens vi ikke gjør dette for matindustrien.

Videreutvikling av analysen bør også innebære en grundig gjennomgang av avgiftene på leddene i verdikjedene. Manglende gjennomsiktighet i føringen av avgiftene skaper stor usikkerhet. I figur 9 fremstår norsk matindustri som en netto subsidiert næring, i sterk kontrast til svensk matindustri. Det er grunn til å dokumentere denne forskjellen bedre, herunder grensedragningen mellom produkt- og næringsavgifter, samt hvor i verdikjeden avgifter og støtte plasseres.

I analysen bak figur 11 har vi sammenlignet prosentvise marginer og bearbeidingsverdier mellom land og over tid, og regnet synkende prosentvise relative bruttomarginer i detaljhandelen i Norge som en prisdempende effekt. Det er da viktig å være klar over at når prisnivået $\mathrm{i}$ Norge stiger relativt til prisnivået for gjennomsnittet av Sverige og Danmark, kan en redusert margin i prosent være forenlig med økt fortjeneste for samme omsatte mengde. Vi viser her bare effekten av endringer i prosentvise, relative marginer for gitte endringer i samlet forbruk.

Undersøkelsen skal, i tillegg til å bryte ned prisforskjeller på enkeltfaktorer, også styrke bakgrunnen for analyse av konkurranseforholdene i verdikjeden for matvarer. Marginbildet kan kun gi et begrenset bidrag til en full evaluering av relativ konkurranse. Resultatene fra vår pris- og 
marginanalyse styrker imidlertid ikke argumentene for å rette søkelyset mot detaljistleddet som årsak til relativ voksende ineffektivitet eller markedsmakt i verdikjeden for matvarer. Det er noe større grunn til å se på engrosleddet, dvs. leddet der forhandlingene med leverandørleddet utføres. Men engrosleddet har en begrenset bruttomargin sammenlignet med detaljistleddet, så effektene av markedsmakt blir begrenset for verdikjeden under ett. Sagt på en annen måte: konkurransen på detaljistleddet veier totalt sett tyngre for forbrukerne enn konkurransen på engrosleddet.

Med nedgangen i relative, prosentvise bruttomarginer for detaljistene, kan det også være mer sannsynlig at en kilde til relativt høye bruttomarginer for grossistene kan ligge i gunstig utvikling i engrosleddets avregningspriser nedstrøms. Det betyr i så fall at grossistleddet i dagligvarehandelen har hatt gunstigere utvikling i sine salgspriser mot både egne og selvstendige detaljistkjeder, enn detaljistene har hatt mot forbruker. For å se om det kan være økende utnyttelse av markedsmakt på engrosleddet i Norge sammenlignet med andre land, bør i det minste driftsresultatene trekkes inn.

Undersøkelsen av priser og marginer støtter opp om resultatene fra produktivitetsanalysen (Pettersen et al., 2020). Vi har ikke komparative produktivitetsanalyser for Norge og nabolandene, men nevnte artikkel viser høyere produktivitetsvekst i på detaljistleddet enn i engroshandel og matindustri.

Takk for nyttige kommentarer til kapitlet fra Per Ingvar Olsen, BI, Frode Steen, FOOD/NHH, til kollega Signe Kårstad for bidrag $i$ arbeidet, og til Siri Voll Dombu, Menon, Per Christian Rålm, Felleskjøpet, og kollegaene Øyvind Hoveid og Sjur Spildo Prestegard for kommentarer og bidrag til forutgående studier av prisutviklingen i verdikjeden for matvarer. 


\section{Referanser}

Asheim, L. J., Bakken, A. K., Mittenzwei, K., Pettersen, I. \& Prestegard, S. S. (2019). Konsekvenser av redusert kjøttforbruk: Scenarioanalyser med vekt på endringer i selvforsyning, arealbruk og struktur i jordbruk og kjøttindustri (NIBIO Rapport 5/170). Hentet fra http://hdl.handle.net/11250/2634831

Bergset, N. Ø., Svennerud, M., Pettersen, I. \& Kjuus, J. (2008). Marginer i egg- og kjøttsektoren - utvikling i priser fra bonde til butikk (NILF Notat 2008/20). Hentet fra http://hdl.handle.net/11250/2494649

EU/High Level Forum. (2014). High level forum for a better functioning food supply chain (Rapport HLF/o18). Hentet fra https://ec.europa.eu/transparency/ regexpert/index.cfm?do=groupDetail.groupDetailDoc\&id=25052\&no=2

Friberg, R., Pettersen, I., Steen, F. \& Ulsaker, S. A. (2020). Annerledeslandet Norge: butikktilgjengelighet og markedskonsentrasjon i Sverige og Norge. I F. Steen \& I. Pettersen (Red.), Mot bedre vitende i norsk matsektor (Kap. 2, s. 35-70). Oslo: Cappelen Damm Akademisk.

Gaasland, I. (2011). Jordbrukspolitikk, matvarepriser og vareutvalg. I I. Pettersen \& T. Gabrielsen (Red.), Dagligvarehandel og mat 2011. Perspektiver på verdikjedene for matvarer (NILF Rapport, s. 67-86). Oslo: Norsk institutt for landbruksøkonomisk forskning.

Gaasland, I. (2020). Verdikjeden for mat - importbeskyttelse eller konkurranse? I F. Steen \& I. Pettersen (Red.), Mot bedre vitende i norsk matsektor (Kap. 5, s. 158-192). Oslo: Cappelen Damm Akademisk.

Gabrielsen, T. S., Steen, F., Sørgard, L. \& Vagstad, S. (2013). Kjøpermakt $i$ dagligvaresektoren (Rapport skrevet for Fornyings-, administrasjons- og kirkedepartementet). Hentet fra https://www.regjeringen.no/no/dokumenter/ kjopermakt-i-dagligvaresektoren/id723054/

NOU 2007: 8. (2007). En vurdering av saravgiftene. Oslo: Finansdepartementet.

NOU 2011: 4. (2011). Mat, makt og avmakt - om styrkeforholdene i verdikjeden for mat. Oslo: Landbruks- og matdepartementet.

NOU 2019: 8. (2019). Saravgiftene på sjokolade- og sukkervarer og alkoholfrie drikkevarer. Oslo: Finansdepartementet.

Oslo Economics/Oeconomica. (2017). Etableringshindringer i dagligvaresektoren (Rapport utarbeidet på oppdrag fra Nærings- og fiskeridepartementet, 2017-46). Hentet fra https://osloeconomics.no/wp-content/uploads/Etableringshindringeri-dagligvaresektoren_ref2.pdf

Oslo Economics. (2015). Prisutvikling i dagligvaremarkedet (Rapport 2015/03). Oslo: Oslo Economics. 
Pettersen, I., Steen, F. \& Ulsaker, S. (2020). Produktivitetsutvikling i norsk matsektor. I F. Steen \& I. Pettersen (Red.), Mot bedre vitende i norsk matsektor (Kap. 3, s. 71-123). Oslo: Cappelen Damm Akademisk.

Pettersen, I., Kjuus, J. \& Lavik, R. (2011). Stor prisforskjell - med naturlige, politiske og strukturelle forklaringer. I I. Pettersen \& T. S. Gabrielsen (Red.), Dagligvarehandel og mat 2011. Perspektiver på verdikjedene for matvarer (NILF Rapport, s. 67-86). Hentet fra http://hdl.handle.net/11250/2463843

Pettersen, I. (2016). Markedsordning og regulering i jordbruket. I S. S. Prestegard, K. Mittenzwei \& A. K. Hegrenes (Red.), Norsk jordbrukspolitikk: Handlingsrom i endring. Bergen: Fagbokforlaget.

Rålm, P. C. (Red.).(2014). Mat og industri 2014. Status og utvikling i norsk matindustri (NILF Rapport). Hentet fra http://hdl.handle.net/11250/2447572

Strøm, Ø., Pettersen, I., Sandberg, L., Martinsen, T., Myran, K. \& Fløttum, E. J. (1999). Matens pris - Marginberegninger, sammenligninger, metodedrøfting (NILF-rapport 4/1999). Oslo: Norsk institutt for landbruksøkonomisk forskning. 


\title{
Verdikjeden for mat - importbeskyttelse eller konkurranse?
}

\section{Ivar Gaasland}

\section{Handelshøyskolen BI}

\begin{abstract}
In Norway, the consumers' food bill is 37 billion NOK (EUR 730 per capita in 2018) higher than in Sweden and Finland, who participate in free trade within the EU-market. Since the farmers' market price support only accounts for $1 / 4$ of this extra bill, the remaining $3 / 4$ arises from higher costs and mark-ups downstream in the value chain. In this chapter, I analyze how and through which channels the heavy Norwegian import barriers on food affect competition and efficiency in the value chain. The direct effect is high concentration and weak competition in the domestic food industry. Shortage of alternatives to large domestic food suppliers creates, as a side effect, severe entry barriers in the retail market. For foreign retail chains, it is not lucrative to establish activity in Norway as long as import barriers make it difficult to bring along their supply networks. With respect to competition among prevailing retail chains, I argue that lack of efficient alternatives to domestic food suppliers facilitates that large domestic suppliers can differentiate their prices according to buyers' individual bargaining power. A first step to strengthen competition in the value chain would be to bring down import tariffs so that import occurs for all product categories. This will expose the domestic food industry to more competition and provide real outside options to retail chains. Import protection of food is hard to defend from economic welfare theory. Farm-related policy objectives can more efficiently be achieved with direct payments rather than measures that hamper competition and distort markets.
\end{abstract}

Keywords: value chain for food, import barriers, competition, networks in trade, welfare theory

Sitering av denne artikkelen: Gaasland, I. (2020). Verdikjeden for mat - importbeskyttelse eller konkurranse? I F. Steen \& I. Pettersen (Red.), Mot bedre vitende i norsk matsektor (Kap. 5, s. 158-192). Oslo: Cappelen Damm Akademisk.

https://doi.org/10.23865/noasp.93.ch5

Lisens: CC BY-ND 4.0. 


\section{Introduksjon}

Over lang tid har det pågått en intens debatt om konkurranse og maktforhold i verdikjeden for mat. Endringer i maktforhold har vært en viktig pådriver for debatten. Mens leverandørsiden tradisjonelt har hatt selgermakt overfor mange små og uavhengige kjøpmenn, er dette over tid blitt motsvart av kjøpermakt fra butikksiden. Tre butikkjeder med vertikalt integrerte grossistfunksjoner har i dag kontroll over det meste av dagligvaremarkedet. I forhandlinger om innkjøpsbetingelser møter disse kjedene en leverandørside som også domineres av store aktører. Ikke overraskende kommer næringsinteressene på banen når maktforhold forskyves mellom store aktører i en verdikjede som i 2018 omsatte for 176 milliarder kroner.

Offentlige utredninger og ulike interessenter har kommet med mange forslag til tiltak for å skape mer like eller «rettferdige» konkurransevilkår. Mest omtalt er «Lov om god handelsskikk» (etter forslag fra Matkjedeutvalget; NOU 2011:4), forbud mot diskriminerende innkjøpspriser i dagligvarehandelen og mer aktiv bruk av Konkurranseloven. Diskriminerende innkjøpspriser har spesielt fått oppmerksomhet etter at Konkurransetilsynet påviste store forskjeller i dagligvarekjedenes innkjøpspriser (Konkurransetilsynet, 2019). Fra flere hold er det blitt hevdet at forskjeller i innkjøpspriser mellom kjedene hemmer konkurransen (Foros \& Kind, 2018) og kanskje er den viktigste etableringshindring i dagligvaresektoren (Oslo Economics, 2017). En arbeidsgruppe nedsatt av Nærings- og fiskeridepartementet har vurdert om prisdiskriminering bør forbys (Gabrielsen, Moen \& Nilssen, 2020). Gruppen konkluderer med at et forbud mot prisdiskriminering vil kunne gi høyere leverandørpriser og dyrere dagligvarer, og derfor ikke bør innføres. Samtidig erkjennes det at bransjen preges av konkurranseproblemer, men det poengteres at dette bør håndteres innenfor den eksisterende konkurranselovgivningen.

Et fellestrekk ved alle foreliggende utredninger og forskningsbidrag er at importvernet for matvarer tas for gitt og ikke drøftes spesifikt i sammenheng med konkurranseproblemene i verdikjeden. Det er da en fare for at de konkurransepolitiske analysene ikke konfronterer kjernen av 
problemet, men handler om å finne kompenserende tiltak for importvernets konkurransehemmende effekt. Et relevant spørsmål er om den akademiske og politiske debatten egentlig skjer på særinteressers og ikke forbrukernes premisser. Intensjonen med denne artikkelen er å gi en prinsipiell og helhetlig analyse av hvordan og gjennom hvilke mekanismer importvernet kan tenkes å påvirke konkurranse, samarbeidsformer og effektivitet i verdikjeden. I forlengelsen av analysen drøftes det om importvernet egentlig er nødvendig for å sikre nasjonale interesser eller oppfylle jordbrukspolitiske målsettinger. Til slutt skisseres en reform som kan gi gunstige konkurranseeffekter uten å være til hinder for bøndenes inntekter og jordbruksaktivitet.

Avsnitt 2 presenterer sentrale økonomiske kjennetegn ved verdikjeden for mat, og gjør rede for karakteristiske trekk som en forventer å finne i fravær av importbeskyttelse. Basert på en slik referanseramme, drøftes det i avsnitt 3 hvordan importvernet kan tenkes å påvirke konkurranse, samarbeidsformer og effektivitet i verdikjeden. Her benyttes den norske verdikjeden som gjennomgående eksempel. Avsnitt 4 dokumenterer graden av beskyttelse og faktisk handel for sentrale varegrupper. Mens det primære formålet med importvernet er å beskytte bøndene, argumenteres det for at bieffekten er svekket konkurranse i verdikjeden. Avsnitt 5 drøfter hva som vil skje hvis myndighetene, som et konkurransepolitisk virkemiddel, senker tollsatsene. Spesielt drøftes det om importvernet er nødvendig for å sikre nasjonale interesser eller for å oppfylle jordbrukspolitiske målsettinger. I avsnitt 6 oppsummeres viktige slutninger om sammenhengen mellom importvernet og konkurransen i verdikjeden. Med utgangspunkt i tall over prisforskjeller mellom Norge og EU, drøftes og problematiseres betydningen av de ulike mekanismene med særlig fokus på konkurransen i dagligvaremarkedet. 


\section{Karakteristiske trekk ved en velfungerende verdikjede for mat}

Som en referanseramme skal vi begynne med å drøfte karakteristiske trekk som en forventer å finne i en velfungerende verdikjede for matvarer $i$ et land. Med velfungerende mener vi en verdikjede som gjennom konkurranse i markedene gir forbrukerne høyest mulig overskudd gjennom en kombinasjon av variasjon, kvalitet og priser. ${ }^{1}$ Normal konkurransepolitikk og fravær av importvern og andre offentlig bestemte etableringshindringer tas som et premiss. Drøftingen baseres på sentrale kjennetegn ved sektorene i denne verdikjeden og ser dette i sammenheng med økonomisk teori og empiri.

Verdikjeden kan i grove trekk fremstilles som i figur 1. Oppstrøms finner en jordbruket (bønder), som leverer nedstrøms til matindustrien (f.eks. Tine). Matvarer kan også komme fra utlandet gjennom importører (uavhengige, datterselskap av utenlandske selskap eller dagligvarekjedenes egen import). Ferdige matvarer går deretter videre til grossistleddet (f.eks. Asko), som igjen leverer til butikkene nærmest forbruker (f.eks. Kiwi).

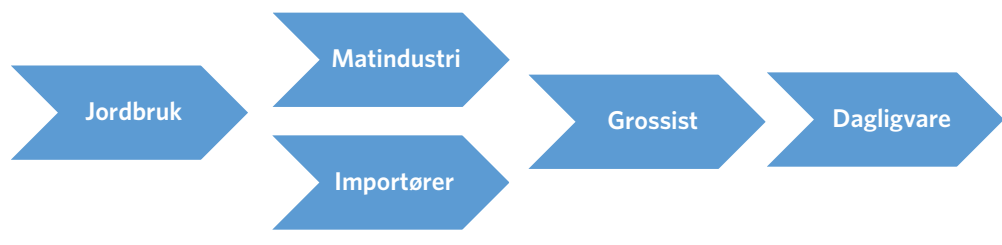

Figur 1 Jordbruksbasert verdikjede.

$1 \quad$ Mer presist kan verdikjedens funksjonsevne måles ut fra evnen til å generere samfunnsøkonomisk overskudd (produsentoverskudd pluss konsumentoverskudd), men hvor konkurranse i markedene legger begrensninger på produsentoverskuddet. 
På tilbudssiden kjennetegnes hvert av de tre siste leddene ved stordriftsfordeler. I industrileddet bunner dette i store, faste investeringer i produksjonsutstyr og produktutvikling. For importører er det faste kostnader ved å investere i relasjoner og nettverk. For multinasjonale selskap er det kostnader ved å etablere datterselskap for salg og markedsføring i et annet land. På grossist- og butikkleddet er det knyttet stordriftsfordeler til distribusjon og salg av et vidt produktspekter til spredte butikker og forbrukere, samt til markedsføring og innkjøpsfunksjoner. Følgelig er det en økonomisk fordel å være stor i bearbeiding, handel, distribusjon og salg av matvarer. Spesielt hvis markedet er lite, er det ikke «plass til» mange aktører, og en kan forvente en viss grad av naturlig konsentrasjon. Dette bidrar til å forklare at relativt få aktører i de fleste land står for brorparten av omsetningen i matindustrien og dagligvarehandelen, ofte i sameksistens med en rekke mindre aktører («competitive fringe») som normalt antas å være pristakere.

Matvarer kan typisk differensieres etter opprinnelse (spesielt nasjonalitet) og ulike attributter (f.eks. smaksnyanser, næringsinnhold, produksjonsmåte og innpakning). Ved å differensiere sitt produkt kan en produsent oppnå markedsmakt for den varianten han er eneselger av (f.eks. Pepsi Max), men må likevel konkurrere med andre varianter innenfor samme produktkategori (f.eks. Cola Zero). I litteraturen kalles dette monopolistisk konkurranse (Chamberlin, 1933; Krugman, Obstfeld \& Melitz, 2018). Kombinert med stordriftsfordeler forklarer det forekomsten av noringsintern handel, eller handel med «like» varer mellom land. Gjennom markedsintegrasjon blir markedet større. Stordriftsfordeler kan utnyttes bedre samtidig som konkurransen øker, og forbrukerne får tilgang til flere produktvarianter til lavere priser. I et velfungerende matmarked forventer en derfor innslag av næringsintern handel. ${ }^{2}$ Mellom land som er tett økonomisk integrert, for eksempel EU-land, kan en derfor observere betydelig import og eksport innenfor samme produktkategori.

Men empiri gir samtidig sterke holdepunkter for at det finnes en grenseeffekt som gir innenlandske aktører en fordel selv i fravær av

2 Om et land mangler komparative fortrinn innenfor en gitt produksjon, vil det normalt ikke skje eksport, og dermed vil det ikke være snakk om næringsintern handel. 
eksplisitte handelshindringer som toll, importkvoter eller byråkratiske forordninger (Evans, 2003; McCallum, 1995). Faste og ikke-gjenvinnbare investeringer ved å etablere nettverk og relasjoner i et annet land er en viktig forklaring (Melitz, 2003). Men også transportkostnader og forskjeller i valuta, standarder, forbrukerpreferanser og forretningskultur skaper handelskostnader. Behovet for investeringer i nettverk er typisk høyere for differensierte (heterogene) enn for homogene varer (Rauch, 1999). For homogene varer, f.eks. råvarer fra jordbruket, kobles selgere og kjøpere relativt lett siden det som regel eksisterer organiserte varebørser eller offentlig tilgjengelige referansepriser. Innenfor varegrupper hvor de enkelte produsenter tilbyr sine egne varianter, for eksempel bearbeidede næringsmidler, finnes det ikke slike lett tilgjengelige markedsplasser. Kjøpere og selgere må da søke seg frem til hverandre og investere i relasjoner. ${ }^{3}$ Geografisk nærhet og tilhørighet (kulturell og språklig) bidrar til å redusere nettverks- og handelskostnader. Dette forklarer i stor grad at mye av handelen i verden skjer mellom nærliggende land. Mer generelt bidrar grenseeffekter og handelskostnader til å begrense antall bedrifter som eksporterer. Empiri viser tydelig at internasjonal handel domineres av bedrifter med høy produktivitet, som regel store multinasjonale selskaper, mens mindre effektive bedrifter kun betjener hjemmemarkedet (Bernard, Jensen, Redding \& Schott, 2007).

Mens bedrifter som er på samme horisontale nivå i verdikjeden (f.eks. Tine og Q-meieriene) selger konkurrerende produkter og av hensyn til forbrukerne ikke bør samarbeide i markedet, stiller saken seg annerledes når det gjelder vertikale relasjoner. Bedrifter som opererer på forskjellig nivå i kjeden (f.eks. Orkla, Asko og NorgesGruppen) produserer nemlig komplementore varer og tjenester, som betyr at det er gjensidig avhengighet mellom partene. Om butikken på eget initiativ setter ned utsalgsprisen eller eksponerer varen bedre, opplever også leverandøren høyere etterspørsel. Tilsvarende vil høyere innkjøpspris eller dårlig kvalitet fra matprodusenten redusere salget til butikken. Slike eksterne virkninger gjør at partene kan tjene på samarbeid og koordinering. Det kan gi

3 Søkekostnadene, og dermed etableringshindringene, er normalt lavere for multinasjonale selskap som har velkjente og globale merkevarer. 
bedre samlet ressursbruk, og slik tjene forbrukerne (Joskow, 2008; Pepall, Richards \& Norman, 2014).

I en velfungerende verdikjede forventer en derfor et betydelig innslag av vertikalt samarbeid som kan spenne fra vertikal integrasjon til ulike kontrakter mellom uavhengige bedrifter. En kontrakt kan kalles effektiv hvis den bidrar til å internalisere eksterne virkninger mellom partene. I matsektoren omhandler kontraktene typisk forpliktelser og rettigheter knyttet til felles markedsføring, eksponering i butikk (hylleplass), produktutvikling, kvalitet, prispolitikk (unngå doble prispåslag) og overskuddsdeling. ${ }^{4}$ Siden effektive kontrakter er lønnsomt for partene, gir de et konkurransefortrinn. Muligheten til å inngå fleksible og effektive kontrakter er med andre ord en viktig konkurranseparameter som ikke bare effektiviserer virksomheten men kan tjene forbrukerne.

I et marked med sunn konkurranse forventes det dynamikk i form av nyetableringer og nedlegginger, oppkjøp, eierskifte og endrede samarbeidskonstellasjoner mellom bedrifter. Bedrifter vil i perioder kunne tjene mer enn normalt, men dette vil etter hvert trekke til seg nye aktører som igjen vil presse ned profitten. Over tid kan det forventes normal avkastning på investert kapital under forutsetning av at det ikke er spesielt høye etablerings- eller handelshindringer i markedet. Mulighetene for nye konkurrenter eller tilgangen til alternative leverandører vil disiplinere prissettingen til aktørene og stimulere til produktutvikling og effektiv drift. Effektive kontrakter og samarbeidsformer er en viktig del av et slikt konkurransebilde.

Men kontrakter og vertikalt samarbeid kan også brukes strategisk for å oppnå fordeler på bekostning av andre aktører, enten ved å svekke konkurransen på horisontalt nivå i kjeden (skaffe markedsmakt) eller for å oppnå en større andel av overskuddet i verdikjeden (skaffe forhandlingsmakt). Konkurranseskadelige effekter kan oppstå gjennom utestenging av konkurrenter, enten ved at en leverandør leverer eksklusivt til en butikkjede

4 I litteraturen omtales slike forpliktelser og rettigheter som vertikale bindinger (Tirole, 1988). 
og slik gir andre kjeder færre alternativ og høyere innkjøpspriser ${ }^{5}$ eller ved at en leverandør «kjøper seg» eksklusiv tilgang til en butikkjede og slik svekker sine konkurrenter (Hjelmeng \& Sørgård, 2014). Faren for at slik atferd skal være til skade for forbrukerne er først og fremst til stede hvis det i utgangspunktet er svak konkurranse på leverandørleddet.

\section{Mulige konsekvenser av handelshindringer - den norske verdikjeden for mat}

I den norske verdikjeden for mat er premisset om fri handel brutt. Som dokumentert i neste avsnitt, er det høye importbarrierer for de fleste matvarer som står i et konkurranseforhold til norske jordbruksvarer. Ifølge en undersøkelse utført av Orkla med informasjon fra AC Nielsen, står produkter som har toll for vel halvparten av omsetningen i norsk dagligvarehandel (Mageli, 2015). For viktige varegrupper, som meieri- og kjøttvarer, er tollsatsene stort sett prohibitive; det vil si at tollsatsene er så høye at de i praksis utelukker import. Spørsmålene vi stiller er hvordan det restriktive importvernet kan tenkes å påvirke konkurranse, samarbeidsformer og effektivitet i verdikjeden.

Begrensninger på handel med andre land er, spesielt for et lite land som Norge, en svært konkurransehemmende offentlig regulering. Den direkte virkningen er at dagligvarekjedene i stor grad begrenses til å kjøpe matvarer fra innenlandske bedrifter. Import og næringsintern handel er derfor på et svært lavt nivå (se avsnitt 4). I en industri som kjennetegnes med stordriftsfordeler, blir det heller ikke plass til mange store bedrifter i et lite marked som det norske. ${ }^{6}$ Etablerte aktører vil ha en naturlig fordel

5 Hvis en leverandør og en butikkjede integrerer vertikalt, vil andre butikkjeder få tilgang til færre leverandører som hver og en făr større selgermakt. Dette kan gi høyere innkjøpspriser for disse kjedene, mens den integrerte butikkjeden kan oppnå lavere priser gjennom mer effektivt samarbeid (f.eks. ved å unngå doble prispåslag). Uten mer informasjonen er det ikke mulig å si noe om hvordan disse to motstridende effektene vil påvirke forbrukerprisene (Salinger, 1988).

6 I tillegg til konkurranseutfordringer fører importvernet i seg selv til høyere priser og mindre vareutvalg. Prisene blir høye siden Norge ikke har fortrinn innenfor jordbruksbasert matproduksjon. Vareutvalget blir mindre som en direkte følge av at tilbudet i stor grad begrenses til innenlandske leverandører. Innenfor grensen av et lite marked er det kostbart å forsyne produktbredde i en matindustri som preges av stordriftsfordeler. 
i kraft av opparbeidet volum og produksjonskapasitet og innarbeidede merkevarer. I fravær av alternativer fra utlandet er det derfor ikke overraskende at konsentrasjonen i den norske matvareindustrien er høy, også sammenlignet med andre land (NOU 2011:4, avsnitt 3.5.4).

I hvilken grad kan det tenkes at importvernet også bidrar til å svekke konkurransen nedstrøms i dagligvareleddet? I det følgende fremsettes og drøftes to viktige mekanismer: 1) importvernet utgjør en sterk etableringshindring for utenlandske dagligvarekjeder, og 2) svak konkurranse og få alternativ til norsk matindustri legger til rette for at store norske leverandører kan differensiere prisene i henhold til kjøpernes individuelle forhandlingsstyrke, noe som kan skape ulike konkurransevilkår mellom kjedene.

En dagligvarekjede lever av å kjøpe inn varer fra leverandører og selge disse til forbrukerne med en margin. Følgelig blir kjedens relasjoner til og nettverk av leverandører viktig for lønnsomheten. Suksesskriterier vil være knyttet til sortiment, merke, kvalitet, pris og logistikk, og konkurransefortrinn kan oppnås gjennom koordinering og samarbeid om prispolitikk, produktutvikling og markedsføring (effektive kontrakter). Her ligger kjernen til å forstå at importvernet utgjør en sterk etableringshindring for utenlandske dagligvarekjeder. Dagligvarekjeder, norske som utenlandske, har sine etablerte nettverk med leverandører. Med hver leverandør er det fremforhandlet kontrakter om leveringsbetingelser, volumrabatter og samarbeid, eller produksjonen kan være integrert med grossist- og butikkvirksomheten. Det er med andre ord foretatt betydelige faste og ikke-gjenvinnbare investeringer i vertikale relasjoner som gjør at kjeden kan operere effektivt. Når importvernet hindrer en utenlandsk dagligvarekjede å ta med seg sitt nettverk av leverandører, er det mindre attraktivt å etablere seg i Norge. Uten dette nettverket vil kjeden i stor grad være prisgitt norske leverandører for sentrale varegrupper (f.eks. meieriprodukter, kjøttvarer og egg). Nye investeringer i nettverk

7 Matkjedeutvalget (NOU 2011:4) fant at markedsandelene til de tre største leverandørene er over $80 \%$ for de fleste viktige produktkategorier, og at varer som omfattes av importvern generelt skiller seg ut med høy konsentrasjon. Spesielt er konsentrasjonen høy for meierivarer, kjøtt og egg. Et fătall norske leverandører, spesielt Tine, Nortura og Orkla, står bak produkter som utgjør en betydelig del av omsetningen i dagligvarehandelen. Store internasjonale leverandører er Coca-Cola Company, Procter \& Gamble, Mondelez og Kellogg's, som alle selger produkter som ikke er tollbelagte eller som sorterer under RÅK-ordningen (beskrevet i avsnitt 4). Se Oslo Economics (2017) for en nærmere oversikt over markedsstrukturen i matindustrien. 
og relasjoner må foretas, og forhandlingsstyrken vil i utgangspunktet være svak på grunn av små volum og få alternativ.

Fravær av utenlandske dagligvarekjeder med sine etablerte nettverk og merkevarer kan på liknende måte bidra til å beskytte innenlandske næringsmiddelbedrifter. Hvis en utenlandsk dagligvarekjede etablerer seg, vil det følge med på kjøpet en rekke nye leverandører og merkevarer som vil utfordre etablerte merkevarer i det norske markedet. Det vil åpne en salgskanal som gir nye leverandører innpass i det norske markedet. Som redegjort for i avsnitt 2, kan dette spesielt være viktig for mer bearbeidede og differensierte varer (merkevarer) hvor handelen er avhengig av nettverk og relasjoner.

Innkjøpsprisen fra leverandør er naturligvis en svært viktig konkurranseparameter for en dagligvarekjede. Mens det frem til 1970-80 tallet typisk var mange små og uavhengige kjøpmenn som hver ikke kunne påvirke sine leveringsbetingelser, er butikkene i dag stort sett organisert i tre store dagligvarekjeder som har styrke til å påvirke innkjøpsprisene. ${ }^{8}$ Konsolideringen i dagligvaremarkedet har gjort at leverandørenes selgermakt i økende grad er blitt motsvart av kjøpermakt. Som tidlig argumentert for av Galbraith (1952), er kjøpermakt i sisteleddet i verdikjeden bra for forbrukerne så lenge det er tilstrekkelig konkurranse mellom dagligvarekjedene. Ved å utnytte kjøpermakt kan dagligvarekjedene presse ned innkjøpsprisene. Gjennom konkurranse i sluttmarkedet overføres dermed overskudd fra leverandørene til forbrukerne. ${ }^{9}$

8 Kapittelet «Annerledeslandet Norge» (Friberg, Pettersen, Steen \& Ulsaker, 2020) viser, med 2018-tall fra AC Nielsen, at de tre største kjedene i Norge har en samlet markedsandel på 96,2 \%. Denne er fordelt med 43,2 \% på NorgesGruppen, 29,3 \% på Coop og 23,7 \% på Rema 1000.

9 Konsolideringen i dagligvaremarkedet har sammenfalt med høy produktivitetsvekst (Pettersen, 2013). Dette gjenspeiler trolig bedre utnytting av stordriftsfordeler og effektivitetsgevinster ved integrering av grossist- og innkjøpsfunksjoner. Til sammenligning har produktivitetsutviklingen i den norske matindustrien vært relativt lav (Pettersen, 2013). Dette kan blant annet skyldes svak konkurranse, strukturproblemer knyttet til jordbrukspolitikk og kostnader ved markedsregulering. Det er sannsynlig at effektiviseringen i dagligvarebransjen og utviklingen i retning av økt kjøpermakt har tjent forbrukerne. Det vil si at deler av besparelsene gjennom effektivisering og lavere innkjøpspriser er blitt overført til forbrukerne gjennom priskonkurranse i sluttmarkedet. Høy og tiltakende konsentrasjon i dagligvaremarkedet kan imidlertid være et konkurransemessig faresignal. Avkastningen på anvendt kapital i dagligvarebransjen er relativt høy. Ifølge årsmeldingene har for eksempel NorgesGruppen hatt en avkastning på anvendt kapital på mellom 12 og $15 \%$ de siste 5-6 årene. Matkjedeutvalget (NOU 2011:4, Vedlegg 14) påviste at prisene i norske dagligvarebutikker er høyere enn i våre naboland også for varer som ikke er underlagt importvern. 
Kjøpermakt henger nøye sammen med hvilke alternativ og økonomiske pressmidler de involverte aktørene har. En stor dagligvarekjede som i møte med en leverandør kan vise til troverdige alternativ, har høy forhandlingsstyrke. Kjedens alternativ kan for eksempel være vertikal integrasjon med en konkurrerende leverandør (som gir egen produksjonskapasitet), produksjon av egne merkevarer, eller utvidet samarbeidet med andre norske leverandører. Pressmidler kan være knyttet til vareeksponering, mindre innkjøp eller total utestenging («delisting»). Søk etter alternativ og tilhørende bruk av økonomiske pressmidler er en viktig del av et sunt konkurransemarked. Det bidrar til å disiplinere leverandørenes prissetting og styrker deres insentiver til effektiv drift og produktutvikling.

Problemer oppstår når det som i Norge er sterke konkurransehemmende reguleringer på leverandørleddet. Som nevnt utelukkes i stor grad utenlandske leverandører gjennom importvernet slik at dette leddet domineres av noen få innenlandske aktører. Svak konkurranse og få alternativ til norsk matindustri kan legge til rette for at store norske leverandører kan differensiere prisene i henhold til kjøpernes individuelle forhandlingsstyrke. ${ }^{10}$ Dette kan forklare at dagligvarekjedene synes å oppnå forskjellige leveringsbetingelser, som indikert av Konkurransetilsynet (2019). Ved å legge til rette for effektive utsidealternativ gjennom lettelser i importvernet, og slik øke konkurransen på leverandørsiden, vil mulighetene til å diskriminere mellom dagligvarekjeder svekkes. ${ }^{11}$ Forskjeller i forhandlingsmakt mellom dagligvarekjedene vil dermed få mindre betydning. Konkurransen i dagligvaremarkedet vil kunne øke,

10 Når vi snakker om prisdiskriminering eller differensiering av innkjøpsbetingelsene, mener vi forskjeller som ikke kan forklares ved spesifikke kostnader eller motytelser, som for eksempel stordriftsfordeler i forsyning, markedsføring eller eksponering.

11 Anta for eksempel at Tine selger Norvegia billigere til NorgesGruppen enn til Rema. Siden Tine har en dominerende posisjon i det norske markedet, vil en slik prisdiskriminering kunne være mulig. Hvis tollsatsene på standard hvitost senkes såpass mye at det blir lønnsomt å importere f.eks. Gouda eller Emmentaler, vil Rema få kraftige utsidealternativ som kan brukes i forhandlingene med Tine. Utesidealternativene vil i stor grad bestemme prissettingen i det norske markedet, noe som betyr at Tine vil kunne bli tvunget til å sette ned prisene til både NorgesGruppen og Rema for å ikke miste betydelig salg. Også for mer differensierte produkter, som for eksempel pizza og ferdigmat, vil lettelser i etableringshindringer mot utlandet kunne begrense prissettingen til dominerende nasjonale aktører (jf. teorien om monopolistisk konkurranse beskrevet i avsnitt 2). 
først ved at de tre gjenværende kjedene får mer like konkurransevilkår og dernest ved at det kan bli lettere for nye aktører å etablere seg.

Mangel på utsidealternativ kan virke selvforsterkende på markedsposisjonen til den dagligvarekjeden som har størst forhandlingsmakt. ${ }^{12}$ Lavere innkjøpspriser gir større konkurransekraft. ${ }^{13}$ Dette legger til rette for høyere salg og økt markedsandel. I neste omgang vil dermed forhandlingsmakten være ytterligere styrket i forhold til konkurrerende kjeder. Asymmetrien mellom kjedene vil slik kunne øke gradvis over tid. Mangel på konkurranse i leverandørleddet kan legge til rette for en slik dynamikk.

I fravær av effektive utsidealternativ kan en også risikere at relasjonene mellom leverandører og butikkjeder drives av søken etter forhandlingsmakt (strategisk) heller enn å oppnå konkurransefortrinn gjennom samordnet og effektiv drift (effektive kontrakter). For å sikre seg en større del av overskuddet i verdikjeden, kan det være lønnsomt for en dagligvarekjede å foreta investeringer som skaper forhandlingsstyrke overfor en leverandør, selv om dette skulle redusere kakens totale størrelse. $\AA$ etablere egen produksjonskapasitet eller egne konkurrerende merkevarer kan på grunn av stordriftsfordeler være kostbart for en kjede, men likevel lønnsomt hvis det gir økt forhandlingsstyrke og slik bidrar til å presse ned innkjøpsprisene på varene til den etablerte leverandøren. Fordelingsspørsmålet kan dermed skygge for hensynet til effektivitet. Igjen er det mangelen på effektive utsidealternativ som kan skape en slik form for uproduktiv profittsøking. Som argumentert for ovenfor, vil økt konkurranse på leverandørleddet kunne redusere betydningen av forhandlingsmakt siden overskuddet på leverandørleddet vil avta og mulighetene til å diskriminere mellom dagligvarekjedene vil svekkes. Evnen til å inngå effektive kontrakter og samarbeidsformer vil dermed kunne få en mer sentral rolle som konkurranseparameter.

12 Det er rimelig å anta at forhandlingsstyrken generelt øker med en dagligvarekjedes størrelse eller innkjøp (Inderst \& Valetti, 2011). Konsekvensene for en leverandør blir større hvis en stor kunde finner alternativ. Det kan også tenkes at en stor dagligvarekjede har bedre muligheter til å fremskaffe alternativ; for eksempel vil det være lettere å utnytte stordriftsfordeler i egen produksjon, egne merkevarer e.l.

13 I et marked med priskonkurranse kan den aktøren som har lavest innkjøpspriser oppnå høyere enhetsmarginer enn konkurrerende kjeder selv med lavere utsalgspris (alt annet likt). 


\section{Importvern og handel}

Importvernet for matvarer består av tollsatser, kvoter og administrative ordninger som varierer mellom produktgrupper. Det kan skilles mellom varer fra jordbruk og tilhørende meieri- og kjøttindustri og mer bearbeidede næringsmidler. Førstnevnte er forholdsvis standardiserte varer som er intensive i bruk av råvarer fra norsk jordbruk og som beskyttes med svært høye tollsatser. Tollsatsene for mer bearbeidede og differensierte næringsmidler er lavere, men her krever handelen større investeringer i nettverk og relasjoner. Beskrivelsen av importvernet i dette avsnittet relateres spesielt til konkurransesituasjonen i verdikjeden.

\section{Varer fra jordbruk og meieri- og kjøttindustri}

Råvareintensive varer, som korn, stykningsdeler av kjøtt, melkepulver og ulike standarder av hvitoster, er relativt homogene. Standardiserte varer kan typisk handles i verdensmarkedene (uten spesielle investeringer i nettverk) til internasjonale priser som norske aktører må ta som gitt. Importpris inklusive toll (og andre variable handelskostnader som transport og forsikring) vil da sette en øvre grense på hvor høy pris innenlandske leverandører kan ta uten å miste betydelig salg. For slike varer kan gunstige konkurransevirkninger oppnås ved å redusere tollsatsene såpass mye at det kommer merkbar import innenfor alle produktkategorier. Norske leverandører vil da bli utsatt for konkurranse, og dagligvarekjedene vil få reelle utsidealternativ. Nedenfor skal vi se hvor mye importpris inklusive toll i dag overstiger norsk markedspris for en del viktige produkter. En alternativ indikasjon på om tollsatsene er prohibitive vil være om det faktisk kommer import til ordinære tollsatser. Vi vil derfor også se på tall for faktisk import av matvarer. Men først gis det en kort oversikt over de ulike importordningene. 
I bunn for importvernet ligger høye tollsatser som i prinsippet gjelder likt for alle handelspartnere ${ }^{14}$, men hvor utviklingsland som regel innrømmes en rabatt på 10 prosent. ${ }^{15}$ Ubegrenset import kan skje til disse tollsatsene, som for et utvalg av varer vises i tabell 1 (kolonne 3). Ved siden av tollsystemet finnes importkvoter regulert gjennom handelsavtaler, henholdsvis den multinasjonale WTO-avtalen og ulike bilaterale avtaler hvor EØS-avtalen er viktigst. Endelig skjer det import gjennom såkalte administrative importordninger, hvor det skilles mellom kvoteimport for produkter vi normalt ikke er selvforsynt med (som korn) og midlertidige tollnedsettelser når det i perioder er underdekning i det norske markedet relativt til avtalt målpris (som storfe de siste årene). En mer detaljert beskrivelse av de ulike importordningene er gitt i Gaasland (2011).

Det er viktig å være klar over at toll og kvoter kan virke ulikt på den innenlandske konkurransen. I et marked med perfekt konkurranse og homogene varer er disse instrumentene ekvivalente ved at de for samme importmengde vil gi identisk tilpasning i markedet (Bhagwati, 1965). Men når det er svak konkurranse, som i det norske leverandørmarkedet, vil en kvote gi høyere forbrukerpris enn en tollsats som gir samme importmengde (Corden, 1971). Årsaken er at en tollsats legger en øvre grense på hvor høy pris innenlandske aktører (også en monopolist) kan ta i markedet, mens en kvote gir en absolutt importmengde som ikke kan overstiges selv om de innenlandske aktørene øker prisen.

Naturligvis vil en importkvote, f.eks. for ost fra EU, redusere markedet for norske meierier, men den vil i liten grad påvirke konkurranseforholdene i meierisektoren. En bindende tollsats vil derimot utsette innenlandske meierier for konkurranse som setter en øvre grense på hvor høy pris innenlandske meierier kan ta uten å miste betydelig salg. Om tollsatsene settes så høyt at løpende import utelukkes (prohibitive satser), forsvinner stort sett konkurranseeffekten.

\footnotetext{
14 De såkalte MFN-tollsatsene («Most Favoured Nation») fastsatt i WTO som Norge er bundet til å ikke overskride.

15 WTO-avtalen tillater at det gis preferanser overfor utviklingsland gjennom den såkalte GSPordningen («Generalized System of Preferences»).
} 
Tabell 1 sammenligner priser mellom Norge og utlandet for et utvalg av sentrale jordbruksvarer. Norske priser er på engros- eller produsentnivå, mens de utenlandske prisene er registrerte enhetsverdier ved faktisk import i 2018 (se beskrivelsen under tabellen). Forskjellen mellom faktisk toll (kolonne 3) og prisforskjellen mellom Norge og utlandet (kolonne 5) utgjør overbeskyttelsen i tollvernet (kolonne 6). Den siste kolonnen viser hvor mye dagens tollsats må reduseres for at overbeskyttelsen skal tas ut. Hovedbildet som tabellen viser er at tollsatsene gir betydelig overbeskyttelse, både for varer som beskyttes med krone- og prosenttoll. For de fleste varer må dagens tollsats mer enn halveres for at importpris inklusive toll skal komme ned til norsk prisnivå. Det betyr at tollsatsene er så høye at de hindrer importkonkurranse. ${ }^{16}$

16 Importprisene i tabell 1 er generelt høyere enn verdensmarkedsprisene som OECD benytter i sine beregninger av jordbruksstøtte i sine medlemsland. Den viktigste forklaringen er trolig at vi har benyttet registrerte priser ved import til Norge som ofte gjelder små kvantum fra våre naboland, mens OECD samler inn realistiske importpriser på verdensmarkedet som helhet. Konklusjonen om at det er overbeskyttelse i tollsatsene er robust selv med OECDs priser. 
Tabell 1 Priser, tollsatser og beskyttelsesgrad for sentrale jordbruksvarer (2018).

\begin{tabular}{|c|c|c|c|c|c|c|c|}
\hline & 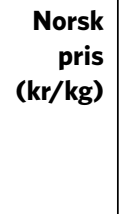 & $\begin{array}{r}\text { Import- } \\
\text { pris } \\
(\mathbf{k r} / \mathbf{k g})\end{array}$ & $\begin{array}{r}\text { Toll } \\
\text { (\% el. } \\
\text { kr/kg) }\end{array}$ & $\begin{array}{r}\text { Import- } \\
\text { pris pluss } \\
\text { toll } \\
(\mathbf{k r} / \mathbf{k g})\end{array}$ & $\begin{array}{r}\text { Norsk pris } \\
\text { minus } \\
\text { importpris } \\
(\mathrm{kr} / \mathrm{kg})\end{array}$ & $\begin{array}{r}\text { Overbes- } \\
\text { kyttelse i } \\
\text { tollvernet } \\
\text { (kr per kg) }\end{array}$ & $\begin{array}{r}\text { Nodvendig } \\
\text { tollreduks } \\
\text { jon for } \\
\text { fjerne ove } \\
\text { beskyt } \\
\text { telsen }\end{array}$ \\
\hline \multicolumn{8}{|l|}{ Meierivarer } \\
\hline Kumelk & 5,71 & 3,25 & $388 \%$ & 15,86 & 2,46 & 10,15 & $80 \%$ \\
\hline Hvitost & 96,00 & 67,59 & $277 \%$ & 254,81 & 28,41 & 158,81 & $85 \%$ \\
\hline Brie & $\mathrm{n} / \mathrm{a}$ & 67,05 & 27,15 & 94,20 & $\mathrm{n} / \mathrm{a}$ & $\mathrm{n} / \mathrm{a}$ & $n / a$ \\
\hline Smør & 69,00 & 54,89 & 25,19 & 80,08 & 14,11 & 11,08 & $44 \%$ \\
\hline Yoghurt, naturell & $\mathrm{n} / \mathrm{a}$ & 22,33 & 8,45 & 30,78 & $\mathrm{n} / \mathrm{a}$ & $\mathrm{n} / \mathrm{a}$ & $n / a$ \\
\hline \multicolumn{8}{|l|}{ Kjøtt } \\
\hline $\begin{array}{l}\text { Storfe: skrotter, } \\
\text { fersk/kjølt }\end{array}$ & 49,75 & 34,38 & 32,28 & 66,66 & 15,37 & 16,91 & $52 \%$ \\
\hline $\begin{array}{l}\text { Storfe: biffer, } \\
\text { fersk/kjølt }\end{array}$ & $\mathrm{n} / \mathrm{a}$ & 133,47 & $344 \%$ & 592,61 & $\mathrm{n} / \mathrm{a}$ & $\mathrm{n} / \mathrm{a}$ & $n / a$ \\
\hline $\begin{array}{l}\text { Svin: skrotter, } \\
\text { ferskt/kjølt }\end{array}$ & 24,57 & 18,07 & 24,64 & 42,71 & 6,50 & 18,14 & $74 \%$ \\
\hline $\begin{array}{l}\text { Svin: skinker, } \\
\text { saltet/tørket }\end{array}$ & $\mathrm{n} / \mathrm{a}$ & 83,00 & 60,32 & 143,32 & $\mathrm{n} / \mathrm{a}$ & $\mathrm{n} / \mathrm{a}$ & $n / a$ \\
\hline $\begin{array}{l}\text { Svin: sideflesk, } \\
\text { fersk/kjølt }\end{array}$ & $\mathrm{n} / \mathrm{a}$ & 33,26 & 64,96 & 98,22 & $\mathrm{n} / \mathrm{a}$ & $\mathrm{n} / \mathrm{a}$ & $n / a$ \\
\hline $\begin{array}{l}\text { Lam: skrotter, } \\
\text { fryst }\end{array}$ & 38,81 & 48,87 & $429 \%$ & 258,53 & $-10,06$ & 219,72 & $105 \%$ \\
\hline $\begin{array}{l}\text { Kylling: fersk, } \\
\text { kjølt }\end{array}$ & 26,41 & 22,57 & 48,40 & 70,97 & 3,84 & 44,56 & $92 \%$ \\
\hline \multicolumn{8}{|l|}{ Korn } \\
\hline Hvete & 3,32 & 2,09 & 2,13 & 4,22 & 1,23 & 0,90 & $42 \%$ \\
\hline Bygg & 2,79 & 2,12 & 1,74 & 3,86 & 0,67 & 1,07 & $62 \%$ \\
\hline Havre & 2,52 & 2,43 & 1,52 & 3,95 & 0,09 & 1,43 & $94 \%$ \\
\hline Egg & 19,16 & 11,14 & 12,59 & 23,73 & 8,02 & 4,57 & $36 \%$ \\
\hline
\end{tabular}

Kilder: Kolonne 1 viser engrospriser for hvitost, smør, storfe, svin, kylling og egg (2018), som for hvitost og smør er hentet fra Budsjettnemda for jordbruket (2019a) og for storfe, svin, kylling og egg (januar 2018) fra https://www.landbruksdirektoratet.no/no/statistikk/prisutvikling/svin. Prisene for korn og lam er produsentpriser oppgitt av Budsjettnemda for jordbruket (2019b). Importprisene er enhetsverdier for faktisk import i 2018 funnet i Statistikkbanken til SSB, unntatt for melk, som er produsentprisen i EU hentet fra Landbruksdirektoratet (2019a). Tollsatsene er hentet fra https://tolltariffen.toll.no/templates_TAD/Tolltariffen. 
En indikasjon på om tollsatsene er prohibitive kan en også få ved å se på tall for import. Tabell 2 viser at importen er svært lav for alle jordbruksvarer utenom hvete, storfekjøtt og ost. For de to førstnevnte er det snakk om administrativ import. Av naturgitte årsaker er det underdekning på mathvete i Norge, og det skjer derfor regelmessig kvoteimport til nedsatt toll. For storfekjøtt har det de senere år vært underdekning relativt til produsentprisen som er avtalt i Jordbruksoppgjøret («målprisen»), og tollsatsen har dermed vært satt ned. Under normale omstendigheter gir de ordinære tollsatsene for storfe, vist i tabell 1, intet realistisk rom for import. Som vist i den siste kolonnen i tabell 2, er ost den eneste produktkategorien hvor det skjer en del løpende import til ordinære tollsatser. Siden tollsatsen er svært høy for standard hvitost (277 prosent), er det hovedsakelig spesialoster som importeres til en toll på 27,15 kr per kg.

Tabell 2 Produksjon og handel med jordbruksvarer i 2018 (millioner kg).

\begin{tabular}{|l|r|r|r|r|r|}
\hline & $\begin{array}{r}\text { Norsk } \\
\text { produksjon }\end{array}$ & Import & Eksport & $\begin{array}{r}\text { Import- } \\
\text { andel }\end{array}$ & $\begin{array}{r}\text { Import til } \\
\text { ordinære } \\
\text { tollsatser }\end{array}$ \\
\hline Hvete $^{\star \star}$ ) & 399 & 303,8 & & 0,76 & \\
\hline Bygg $^{\star \star}$ ) & 576 & 0,1 & 0,1 & 0,00 & \\
\hline Havre ${ }^{\star \star}$ ) & 283 & 6,2 & & 0,02 & \\
\hline Kumelk & 1526 & & & 0,00 & \\
\hline Ost & 96 & 15,5 & 11,4 & 0,15 & \\
\hline Storfekjøtt & 27 & 10,6 & 0,6 & 0,11 & \\
\hline Fårekjøtt & 137 & 0,7 & 0,7 & 0,03 & \\
\hline Svinekjøtt & 90 & 2,0 & 6,6 & 0,02 & \\
\hline Kylling & 64 & 0,6 & 0,9 & 0,01 & \\
\hline Egg & & 0,4 & 0,4 & 0,01 & \\
\hline
\end{tabular}

*) Norsk konsum er anslått som norsk produksjon + import - eksport.

**) Tall for korn er fra 2017, siden 2018 var et spesielt år på grunn av tørke.

Kilder: Handelstall er hentet i Statistikkbanken til SSB. Tall for norsk produksjon er funnet i Totalkalkylen for jordbruket (Budsjettnemnda for jordbruket, 2019b).

Opplysninger om import til ordinære tollsatser er hentet fra Landbruksdirektoratet (2019b). 


\section{Bearbeidede næringsmidler}

Hvis en bedrift kan differensiere sitt produkt, vil den være eneselger av sin variant og dermed oppnå markedsmakt. Bedriften kan da påvirke markedsprisen på sin merkevare gjennom solgt mengde. Bearbeidede næringsmidler innenfor produktkategorier som pizza, knekkebrød, sjokolade, supper og ferdigmat, er typiske merkevarer. Selv om en merkevareprodusent er eneselger av sitt produkt (f.eks. Grandiosa fra Orkla), konkurrerer den med andre varianter innenfor samme produktkategori (f.eks. Rustica fra Dr. Oetker). For differensierte varer finnes det som tidligere nevnt ikke lett tilgjengelige markedsplasser eller internasjonale referansepriser. Handelen skjer i større grad gjennom nettverk og bedriftsspesifikke relasjoner som kan være kostbare å etablere og vedlikeholde i et annet land.

Handelen med bearbeidede næringsmidler mellom Norge og EU reguleres gjennom ordningen med råvarepriskompensasjon ( $\mathrm{R} \AA \mathrm{K}$ ) som er en del av EØS-avtalen. Formålet er å kompensere for prisforskjeller på jordbruksråvarer mellom Norge og EU slik at norsk næringsmiddelindustri ikke hemmes av det særnorske, høye prisnivået på råvarer. I møte med importkonkurranse benyttes det prisnedskriving for råvarer kombinert med tollsatser på import, mens det for eksport benyttes eksporttilskudd. Tollsatsene, prisnedskrivningene og eksporttilskuddene skal etter intensjonen være fastsatt slik at konkurransen mellom norske og europeiske næringsmiddelbedrifter ikke forstyrres av nasjonale forskjeller i råvarepriser. Som det fremgår av tabell 3, er tollsatsene ${ }^{17}$ mye lavere enn for kjøtt- og meierivarer, men likevel ikke ubetydelige. ${ }^{18}$ En mer detaljert beskrivelse av R̊̊K-ordningene er gitt i Gaasland (2011).

\footnotetext{
17 De oppgitte tollsatsene gjelder for import fra EU/EØS/EFTA-land som står for hele 92 prosent av importen av matvarer under RÅK-ordningen. Handel med bearbeidede næringsmidler skjer typisk mellom like og nære land.

18 Omregnet til prosent av gjennomsnittlig importpris, utgjorde tollen om lag 6o \% for yoghurt, $20 \%$ for pizza og $10 \%$ for knekkebrød, mens den var ubetydelig for supper og sauser.
} 
Tabell 3 Tollsatser ved import fra EU/EØS/EFTA-land for varer som inngår i ordningen med råvarepriskompensasjon ( $R \AA \AA K)$.

\begin{tabular}{|l|r|}
\hline & Tollsats mot EU/EøS/EFTA (kr per kg) \\
\hline Andre kaker & 1,49 \\
\hline Barnemat & 5,10 \\
\hline Brød og brødvarer & $\star)$ \\
\hline Deiger og mikser av mel & 2,27 \\
\hline Kakaoprodukter & 11,55 \\
\hline Kjeks og småkaker & 1,71 \\
\hline Knekkebrød & 2,33 \\
\hline Mel og flak av poteter & 11,41 \\
\hline Næringsmidler av korn & $\star$ \\
\hline Pasta & 2,33 \\
\hline Pizza & 5,76 \\
\hline Supper og sauser & 0,35 \\
\hline Sukkervarer & 2,18 \\
\hline Tilberedte næringsmidler & 4,00 \\
\hline Yoghurt & 12,33 \\
\hline Øvrig & 0,6 \\
\hline
\end{tabular}

*) Fastsettes ut fra vareinnhold

Kilder: https://lovdata.no/dokument/SF/forskrift/2012-12-20-1424 og https://tolltariffen.toll.no/templates_TAD/Tolltariffen/StartPage. aspx?id=358571\& epslanguage $=$ no

Tabell 4 viser at det skjer import innenfor alle varekategoriene som er definert som RÅK-varer. Totalt var importverdien på 10,8 milliarder kroner (2018) for produktutvalget i tabellen. I fravær av sammenlignbare tall for norsk produksjon er det vanskelig å vite hvor mye importen utgjør av norsk omsetning. Men ved å se på produksjonsmengder som har mottatt prisnedskrivningstilskudd (Landbruksdirektoratet, 2019b), kan importandelen anslås til om lag 30 \% for pizza, 30 \% for supper og nær $50 \%$ for sjokolade. Dette tyder på at importen er av en viss størrelse og slik gir dagligvarekjedene utsidealternativ.

Eksporten er til sammenligning lav og nærmest ubetydelig for de fleste varekategoriene. Men det finnes noen eksempler på varekategorier hvor 
det skjer næringsintern handel (merkbar eksport og import innenfor samme varekategori). Dette gjelder supper (samme verdi som importen), knekkebrød (2/3 av importverdien), sjokolade (1/3 av importverdien) og til en viss grad pizza ( $1 / 5$ av importverdien). Bak denne eksporten står det multinasjonale selskap som i Norge produserer i relativt stor skala (Orkla for pizza og suppe og Mondelez for sjokolade) og nasjonale United Bakery for knekkebrød.

Tabell 4 Handel med utvalgte RÅK-varer i 2018 (verdier i millioner kroner).

\begin{tabular}{|c|c|c|}
\hline Varegruppe & Import & Eksport \\
\hline Yoghurt & 97 & $<1$ \\
\hline Melkebaserte drikkevarer & 193 & $<1$ \\
\hline Osteerstatninger & 58 & $<1$ \\
\hline Barnemat & 158 & 3 \\
\hline Sukkervarer & 1145 & 54 \\
\hline Sjokolade & 1088 & 300 \\
\hline Sjokolademasse & 136 & 23 \\
\hline Iskrem & 179 & 13 \\
\hline Deiger & 288 & $<1$ \\
\hline Pasta & 443 & 5 \\
\hline Frokostblandinger & 370 & 4 \\
\hline Knekkebrød & 247 & 168 \\
\hline Kjeks & 376 & 8 \\
\hline Kake & 344 & 15 \\
\hline Pizza & 315 & 65 \\
\hline Brødvarer & 914 & 20 \\
\hline Øvrige bakverk & 894 & 89 \\
\hline Syltetøy & 70 & 2 \\
\hline Sauser & 970 & 55 \\
\hline Supper & 64 & 63 \\
\hline Modifisert stivelse & 41 & $<1$ \\
\hline Andre næringsmidler & 2388 & 1437 \\
\hline Total for utvalg & 10787 & 2397 \\
\hline
\end{tabular}

Kilde: Landbruksdirektoratet (2019b). 
Handelsmønsteret for bearbeidede næringsmidler er som forventet ut fra tidligere omtalt teori og empiri om monopolistisk konkurranse. At Norge verken har komparative fortrinn innenfor ordinær industriproduksjon eller jordbruksbasert matproduksjon, taler for et betydelig innslag av import men lite eksport. Grenseeffekter og spesielt behovet for faste investeringer i nettverk for å selge merkevarer i et annet land, kan forklare at norske bedrifter likevel har relativt høye markedsandeler i det hjemlige markedet. Det er også som forventet at import og eksport domineres av multinasjonale selskap som er i posisjon til å utnytte stordriftsfordeler i produksjon og salg av merkevarer.

At det, som vist i tabell 4, skjer løpende import innenfor alle produktkategoriene, sier lite om graden av konkurranse siden bearbeidede næringsmidler per definisjon er unike. Om konkurransen er tilfredsstillende, skulle en forvente at prisleiet på bearbeidede næringsmidler ligger på omlag samme nivå som i våre nærmeste naboland. Prissammenligninger på dette nivået i verdikjeden eksisterer ikke, men Eurostats sammenligninger av forbrukerpriser mellom europeiske land (se tabell 5) viser at prisforskjellene mellom Norge og naboland som har frihandel innenfor EU er spesielt høye for RÅK-varer og/eller næringsmidler som ikke er beskyttet av tollsatser (kategorien «Andre matvarer» i tabell 5). Sammenlignet med Sverige og Finland er norsk prisnivå om lag $65 \%$ høyere. For norske forbrukere utgjør dette en årlig merutgift på nær 14 milliarder kroner (se tabell 6).

Slike prisforskjeller kan vanskelig forklares på annen måte enn at det er konkurranseproblemer i verdikjeden. Men siden Eurostat måler prisforskjeller til forbruker, er det vanskelig å si om kildene ligger på leverandørsiden (RÅK-industrien og importører), butikkleddet eller en kombinasjon. På leverandørleddet er det spesielt to kilder til handelskostnader som er særegne for Norge. Først er det RÅK-ordningen som ikke bare inneholder tollsatser (og slik øker prisene og reduserer salget), men også skaper transaksjonskostnader ved at den er komplisert og byråkratisk. Ordningen er gjenstand for forhandlinger i jordbruksoppgjøret og 
innbyr til strategisk tilpasning (Gaasland, 2011). ${ }^{19}$ Empiri viser at diffuse byråkratiske ordninger («red-tape barriers») skaper handelskostnader som begrenser antall aktører som handler (Neary, Maggi \& Mrazova, 2018). For det andre bidrar det særnorske fraværet av utenlandske dagligvarekjeder til å fjerne konkurransepress fra utenlandske leverandører og merkevarer som naturlig følger med ved en etablering i Norge. Uten en salgskanal som gir nye leverandører innpass i det norske markedet, øker terskelen for etablering siden det må foretas nye faste og ikke-gjenvinnbare investeringer i nettverk og relasjoner. For merkevarer som ikke er kjente for norske forbrukere, kan det være vanskelig å opparbeide seg et volum som kan forsvare slike investeringer. En kan da risikere at markedet domineres av noen få aktører. ${ }^{20}$ Dette kan også gjelde for matvarer som ikke er beskyttet av importvern.

\section{Er importvernet på mat nødvendig for å sikre nasjonale interesser?}

\section{Gevinster ved handel}

Fra økonomisk teori er det velkjent at internasjonal handel er et effektivt virkemiddel for å sikre verdiskaping og økonomisk velferd (Krugman, Obstfeld \& Melitz, 2018). Gevinster ved handel kommer hovedsakelig gjennom tre kanaler. Den klassiske forklaringen er at land kan øke sin samlede kjøpekraft ved å spesialisere seg i produksjon og eksport av varer og tjenester som landet kan produsere billigere enn andre land, og importere varer og tjenester som landet er relativt dårlig til å produsere (utnytte komparative fortrinn). Den andre kilden til gevinster er at handel fjerner begrensingene som nasjonal markedsstørrelse legger på mulighetene til å utnytte stordriftsfordeler. Om nasjonale markeder integreres ved å fjerne

19 For noen varer beregnes for eksempel tollen etter en matrise som løper over råvarer (melkefett, melkeprotein, stivelse, mel, kjøtt, egg, ost og bær) og deres prosentmessige innhold i varen, mens den for andre varer fastsettes ut fra en standard resept. Tollsatsene kombineres med satser for prisnedskrivning for norske råvarer beregnet ut fra innholdet i ferdigvaren. Gjennom tilpasning av råvareinnholdet kan en produsent eller importør strategisk påvirke betingelsene.

På importsiden vil typisk store multinasjonale selskap som har høy produktivitet og kjente merkevarer ha et fortrinn, og vil gjerne kunne opptre i sameksistens med den dominerende norske aktøren. 
handelshindringer blir det samlede markedet større slik at stordriftsfordeler kan utnyttes bedre. Innenfor ulike bransjer (f.eks. bilproduksjon, elektronikk og næringsmidler) vil bedrifter i de enkelte land typisk kunne utnytte stordriftsfordeler siden produksjonen kan selges i hele det integrerte markedet. Slik næringsintern handel vil føre til at prisene blir lavere og utvalget større i alle land. Handelen mellom rike land domineres i dag av næringsintern handel. Endelig er handel et kraftig verktøy for å sikre konkurranse i nasjonale markeder, siden tilgangen på aktører $ø$ ker betydelig når markeder integreres. Som tidligere nevnt domineres internasjonal handel av store og effektive bedrifter. Dette bidrar sterkt til å utsette nasjonale aktører, som i utgangspunktet har en fordel gjennom grenseeffekten, for konkurranse.

Av flere grunner er gevinstene ved handel spesielt store for små land. Små land har et lite variert ressursgrunnlag. I Norge har vi for eksempel mer olje og fisk enn innbyggerne kan forbruke, men knapphet på mange andre ressurser. På etterspørselssiden utgjør markedsstørrelsen spesielt i et lite land en begrensning på mulighetene til å utnytte stordriftsfordeler. Endelig vil det i små markeder være plass til relativt få aktører, som kan gjøre det vanskelig å sikre god konkurranse.

Importvernet betyr at Norge for jordbruksbaserte matvarer i liten grad benytter seg av de nevnte gevinstmulighetene. Av naturgitte årsaker er det åpenbart at Norge ikke har komparative fortrinn innenfor volumproduksjon av melk, kjøtt, egg og korn. Likevel holdes produksjonen på et høyt nivå gjennom importvern og skattefinansiert støtte. Avsnitt 4 viste at gevinster ved næringsintern handel heller ikke utnyttes i særlig grad. Til tross for at næringsmiddelindustrien typisk kjennetegnes ved stordriftsfordeler i produksjonen, er det lite import av matvarer som står i et konkurranseforhold til norske jordbruksvarer. Som argumentert for i avsnitt 3, bidrar importvernet til sterk konsentrasjon og konkurranseproblemer i verdikjeden. Effektivitets- og konkurranseproblemene blir spesielt store i et lite land som Norge. 


\section{Er importvernet nødvendig for å sikre viktige nasjonale fellesgoder?}

Vurdert ut fra økonomiske og markedsmessige prinsipper for private goder, er det altså knyttet høye samfunnsøkonomiske kostnader til importvernet. Et omdiskutert spørsmål er om det er koblet fellesgoder som kulturlandskap, miljø, biodiversitet og matvaresikkerhet til matproduksjonen. Produksjonens virkning på verdien av slike goder kan i så fall betraktes som eksterne virkninger av jordbruksaktivitet og slik legitimere offentlige inngrep.

Et iboende problem ved slike fellesgoder er at de i fravær av markedssignaler er vanskelige å verdsette og definere. Men uansett vet en at prisstøtte, herunder importvern, bare vil være et treffsikkert virkemiddel hvis produksjonsteknologien er slik at matvarer og fellesgoder produseres i et fast forhold. Som det gis eksempler på nedenfor, er dette langt fra tilfellet for jordbruksrelaterte fellesgoder. Peterson, Boisvert \& de Gorter (2002) viser at slike goder mest effektivt kan forsynes ved en kombinasjon av subsidier og avgifter på innsatsfaktorer i produksjonen.

La oss ta noen eksempler. Eksisterende undersøkelser tyder på at verdien av kulturskapet høynes av variasjon, miljøvennlig drift, biodiversitet, beitende dyr og «nostalgiske attributter» (Drake, 1992). Selv om slike kjennetegn er koblet til matproduksjon, øker ikke verdien av disse godene proporsjonalt med mengden mat som produseres eller mengden jordbruksareal i drift. Prisstøtte stimulerer til høy intensitet som gjennom mekanisering, spesialisering, monokultur og forurensing bidrar til å forringe verdien av kulturlandskapet. Mer treffsikre virkemidler vil være å betale landeiere direkte for å holde areal og eiendom i hevd etter bestemte kriterier, som å hindre gjengroing, verne dyrkbar jord, ha et minimum av dyr på beite og generelt holde landbrukseiendommene i hevd. Direkte støtte til miljø og landskapspleie, heller enn produksjonsstøtte, er blitt mer og mer vanlig i andre land, som i Østerrike, Sveits og EU.

Matvaresikkerhet er en annen type fellesgode som kan legitimere offentlige inngrep. Det skilles mellom matvaretrygghet og forsyningssikkerhet. At maten er trygg å spise, kan best sikres gjennom kontroll av norskprodusert og importert mat, som i Norge er underlagt Mattilsynet. Forsyningssikkerhet handler om evnen til å sikre befolkningen 
mat under alle omstendigheter. Til enhver tid må behovet for kalorier og næringsstoffer kunne dekkes fra kilder som nasjonal produksjon, lagerhold, import og matvarehjelp. Tradisjonelt tenker en i denne sammenheng på avsperring fra omverdenen (bortfall av import og matvarehjelp). Men selv ikke overfor sistnevnte skrekkscenario vil en politikk som fokuserer på løpende høy selvforsyningsgrad på produktnivå være del av en effektiv forsyningsstrategi. Både konsum og forsyning kan omstilles om nødvendig, inntaket av energi kan reduseres betydelig under en krise, innslaget av fisk og planteføde kan økes på bekostning av mindre energieffektiv føde som kjøtt og melk, og lagerhold av energirike varer som korn og sukker er mulig (Brunstad, Gaasland \& Vårdal, 2005). Sammenvevde økonomier og samarbeid mellom land er kanskje likevel den beste forsikringen mot krig og sammenbrudd i viktige forsyningslinjer.

\section{Er importvernet nødvendig for å oppfylle jordbrukspolitiske mål?}

De høye samfunnsøkonomiske kostnadene ved importvernet kan altså ikke forsvares ut fra hensynet til økonomisk velferdsteori. Jordbrukspolitikk og importvern handler i stor grad om politisk økonomi og særinteresser (Gaasland, 2015). Gjennom selektiv næringspolitikk ønsker det politiske flertallet å opprettholde produksjon, sysselsetting og aktivitet som ikke er samfunnsøkonomisk lønnsom..$^{21}$ De politisk erklærte målene er hovedsakelig knyttet til produksjon av «norske» produkter (produksjonsmål) og jordbruksaktivitet i hele landet (distriktsmål). Er importvernet nødvendig for å oppfylle disse næringspolitiske målene? Hva skjer og hvilke alternative virkemidler finnes hvis myndighetene som et konkurransepolitisk virkemiddel velger å senke tollsatsene?

21 Støtten til jordbruket var i 2017 på 24 milliarder kroner (se OECDs årlige beregninger https:// www.oecd.org/norway/producerandconsumersupportestimatesdatabase.htm), hvorav 14 milliarder var skattefinansiert budsjettstøtte og 10 milliarder forbrukerfinansiert skjermingsstøtte. Støtten bidrar til å dekke forskjellen mellom norske produksjonskostnader og produktenes verdi til internasjonale priser. Støtten er først og fremst rettet inn mot næringspolitiske mål (produksjon og sysselsetting i jordbruket) og i mindre grad mot fellesgoder. En nærmere drøfting av samfunnsøkonomiske kostnader knyttet til jordbrukspolitikken er gitt i Produktivitetskommisjonens første rapport (NOU 2015:1, kapittel 13). 
Som argumentert for i avsnitt 4, vil et første steg for å øke konkurransen i verdikjeden være å redusere tollsatsene på jordbruksvarer så mye at det faktisk kommer import innenfor alle produktkategorier (dvs. eliminerer overbeskyttelsen i tollvernet). Det er i tillegg viktig å rette inn særskilte konkurransepolitiske tiltak mot markedet for bearbeidede næringsmidler, som er kjennetegnet ved spesielt høye prispåslag i verdikjeden sammenlignet med EU-land som kan handle fritt seg imellom. Handelen med bearbeidede næringsmidler krever nettverk og bedriftsspesifikke relasjoner som det er kostbart å etablere i et annet land. For å redusere terskelen for utenlandske merkevareleverandører er det viktig å fjerne ordninger som skaper unødige handelskostnader, som for eksempel RÅK-ordningen.

Gjennom slike tiltak vil norsk matindustri kunne bli utsatt for konkurranse, og dagligvarekjedene vil få reelle utsidealternativ. På leverandørsiden vil bøndene og matindustrien få kraftige insentiver til å differensiere sine varer gjennom produktutvikling og merkevarebygging. Samtidig vil konkurransen virke effektivitetsfremmende, for eksempel gjennom strukturtiltak og mer effektive samarbeidsformer i kjeden. På sluttleddet vil reelle importmuligheter svekke det viktigste etableringshinderet for utenlandske dagligvarekjeder. I tillegg kan en forvente mer like konkurransevilkår mellom dagens dagligvarekjeder når konkurranse på leverandørsiden gjør det vanskeligere å diskriminere mellom dagligvarekjeder.

En lettelse i importvernet vil naturligvis påvirke både virkemiddelbruk og tilpasning i jordbruket og matindustrien, først og fremst gjennom økt konkurranse og dynamikk. For eksempel vil det ikke lengre være mulig å detaljregulere produksjonen av de enkelte produktene slik det gjøres i dag. Det vil heller ikke være mulig å sikre full selvforsyning av produkter, siden dette ikke er forenlig med løpende import. Prisene vil også bevege seg mer i tråd med fluktuasjoner i importpriser. Løpende import vil med andre ord ikke være forenelig med dagens system for markedsregulering, hvor dominerende samvirkebedrifter har ansvar for å styre mot målpriser (fastsatt i jordbruksavtalen) ved hjelp av administrative tiltak (som lagring, eksport, administrativ import og omdirigering av produkter til industriformål). 
Likevel vil en slik reform ikke være til hinder for å opprettholde bøndenes inntekter og jordbruksaktivitet. Bøndene kan kompenseres for bortfall av markedsinntekter ved hjelp av direkte tilskudd. Tilskudd er generelt et mer effektivt virkemiddel for å oppfylle politiske målsettinger i primærjordbruket enn importvern og konkurransebegrensninger. Tilskudd kan rettes direkte mot politiske mål eller fellesgoder knyttet til primærjordbruket. Slik reduseres det samlede støttebehovet, og ikke minst unngås negative følgeeffekter på konkurranse og effektivitet nedover i verdikjeden. Tilskudd som finansieres gjennom progressiv beskatning har i tillegg bedre fordelingsvirkninger enn markedsprisstøtte, som i større grad rammer fattige husholdninger med en høy budsjettandel for mat.

\section{Diskusjon og konklusjoner}

I dette kapittelet er det gitt en prinsipiell og helhetlig analyse av hvordan og gjennom hvilke mekanismer importvernet kan tenkes å påvirke konkurranse og effektivitet i verdikjeden. Den sterke beskyttelsen mot utenlandske matvarer gir opphav til høy konsentrasjon på leverandørleddet. Mangelen på utenlandske alternativ og svak konkurranse på leverandørsiden bidrar igjen til å skape etableringshindringer i dagligvaremarkedet. Når en utenlandsk dagligvarekjede hindres i å ta med seg sitt nettverk av leverandører, er det lite attraktivt å etablere seg i Norge. Fravær av utenlandske dagligvarekjeder fjerner samtidig konkurransepress fra utenlandske leverandører og merkevarer som naturlig ville følge med ved en etablering i Norge. Med referanse til den pågående diskusjonen om diskriminerende innkjøpspriser, er det i kapittelet blitt argumentert for at svak konkurranse og få alternativ til norsk matindustri legger til rette for at store norske leverandører kan differensiere prisene i henhold til kjøpernes individuelle forhandlingsstyrke. Ved å åpne for effektive utsidealternativ gjennom lettelser i importvernet, og slik øke konkurransen på leverandørsiden, vil mulighetene til å diskriminere mellom dagligvarekjeder svekkes. Forskjeller i forhandlingsmakt mellom dagligvarekjedene vil dermed få mindre betydning. Konkurransen i dagligvaremarkedet vil kunne øke, først ved at de tre gjenværende kjedene 
får mer like konkurransevilkår, og dernest ved at det kan bli lettere for nye aktører å etablere seg.

Mens det er åpenbart at importvernet svekker konkurransen og effektiviteten i matindustrien, er det vanskeligere å avgjøre hvilken betydning de nevnte mekanismene har for konkurransen i butikkleddet. Som omtalt i avsnitt 2, er ikke importvernet den eneste hindringen for etablering i dagligvaremarkedet. Stordriftsfordeler i innkjøp, distribusjon og salg gjør at det kan forventes en viss grad av naturlig konsentrasjon. Også $\mathrm{i}$ våre nordiske naboland som har fri handel innenfor EU-markedet, er markedsstrukturen preget av få aktører. Som vist i kapittelet «Annerledeslandet Norge» (Friberg et al., 2020), med 2018-tall fra AC Nielsen, har de tre største kjedene i Sverige, Danmark og Finland en samlet markedsandel $\left(\mathrm{C}_{3}\right)$ på henholdsvis $86,2 \%, 81,6 \%$ og 92,1 \%, mens utenlandskeide dagligvarekjeder har markedsandeler på 4,7 \%, 17,7 \% og 9,6\%. Norge skiller seg likevel ut med spesielt høy $\mathrm{C}_{3}$-konsentrasjon (96,2 \%) og et totalt fravær av utenlandske dagligvarekjeder.

Det er omdiskutert hvorvidt få aktører gir svak konkurranse. I et marked som preges av priskonkurranse (Bertrand-konkurranse) kan konkurransen være sterk selv med få aktører. Om derimot kvantum er den strategiske variabelen (Cournot-konkurranse), vil få aktører normalt bety svak konkurranse. Priskonkurranse er karakteristisk for næringer som omsetter homogene varer, og hvor kapasitet og volum lett kan justeres. Innenfor dagligvarehandel er disse kjennetegnene bare delvis til stede. I betydelig grad selges det differensierte varer, og kapasiteten vil på kort sikt kunne være begrenset av leverandøravtaler og kapasitet hos norske leverandører. Dagligvaremarkedet kan kanskje best beskrives som et to-stegspill hvor kapasitet først settes (gjennom avtaler med leverandører eller egen produksjon), og kjedene deretter konkurrerer i pris. Det kan vises at markedsløsningen da blir omtrent som ved kvantumskonkurranse (Kreps \& Scheinkman, 1983). Få aktører bidrar også til å øke sannsynligheten for prissamarbeid.

Selv om markedsandelene til utenlandske dagligvarekjeder er relativt lave i våre naboland (bortsett fra Danmark), kan deres tilstedeværelse være viktig for konkurransen. For det første kan de bidra til sterkere priskonkurranse i lokale markeder. Hovedsakelig vil dette være i 
tettbefolkede områder hvor utenlandske kjeder typisk etablerer seg først. At utenlandske kjeder er til stede, kan også bidra til å eksponere innenlandske kjeder for latent konkurranse (Baumol, Panzar \& Willig, 1982). Når en utenlandsk kjede allerede har foretatt irreversible investeringer i et land, kan den lettere ekspandere om marginene eller profitten i bransjen blir unormalt høy. Endelig bringer som nevnt utenlandske dagligvarekjeder også med seg nye leverandører og merkevarer som utsetter innenlandske leverandører for konkurransepress.

I forhold til våre viktigste handelspartnere i $\mathrm{EU}$ er det norske importvernet for mat særegent. Mens norske butikkjeder i stor grad begrenses til innenlandske leverandører fra et lite land uten fortrinn innenfor jordbruksbasert matproduksjon, har svenske og europeiske dagligvarebutikker tilgang til leverandører fra 28 land gjennom et tett integrert frihandelsområde. Det er interessant å se hvilke utslag dette gir i form av prisforskjeller mellom Norge og EU-land.

Tabell 5 viser indekser for forbrukerpriser i en rekke europeiske land. Vi har tatt med matvarer som omsettes gjennom dagligvarekjeder, og for sammenligningens skyld noen grupper av detaljvarer som ikke omsettes gjennom dagligvarebutikker. Prisforskjellene fanger opp påslag gjennom hele verdikjeden og inkluderer eventuelle avgifter. Gjennomsnittet for de 28 EU-landene er normalisert til 10o. I tabellen har vi begrenset oss til nordeuropeiske land som vi generelt handler mye med og som har et lønnsnivå som ikke avviker alt for mye fra det norske. ${ }^{22}$ Den påfølgende tabell 6 viser hvor mye prisforskjellene mot Sverige utgjør i merutgifter for norske forbrukere. Merutgiftene er beregnet ut fra de oppgitte prisforskjellene i tabell 5 og opplysninger fra Eurostat om faktiske konsumutgifter i Norge for ulike kategorier av matvarer. ${ }^{23}$

22 En generell tendens er at forbrukerprisene øker med inntekten til et land. Balassa (1964) og Samuelson (1964) har forklart dette ved at det mellom rike og fattige land er større produktivitetsforskjeller i produksjon av varer som kan handles (f.eks. industrivarer) enn for tjenester som må forsynes innenlands (f.eks. dagligvarehandel). Noe av prisforskjellene mellom Norge og andre land skyldes altså at norsk lønnsnivå er høyere. Når en ser på prisforskjeller mellom EUland, kommer den såkalte Balassa-Samuelson effekten stort sett til syne ved at land sør og øst i Europa har indeksverdier lavere enn 100.

23 Merverdiavgiften på matvarer er omtrent den samme i Norge og Sverige, men det er for enkelte bearbeidede matvarer forskjellige særavgifter. 
Tabell 5 Prisforskjeller på forbrukernivå mellom Norge og EU-land (2018).

\begin{tabular}{|l|r|r|r|r|r|r|r|r|r|r|r|}
\hline & & \multicolumn{9}{|c|}{ Dagligvarehandel: Kategorier av matvarer } & \multicolumn{3}{|c|}{ Annen detaljhandel } \\
\hline varer & $\begin{array}{r}\text { Mat- } \\
\text { Nelk, } \\
\text { ost, } \\
\text { egg }\end{array}$ & Kjøtt & $\begin{array}{r}\text { Brød, } \\
\text { korn- } \\
\text { varer }\end{array}$ & $\begin{array}{r}\text { Frukt, } \\
\text { grønt, } \\
\text { potet }\end{array}$ & $\begin{array}{r}\text { Oljer, } \\
\text { fett }\end{array}$ & Fisk & $\begin{array}{r}\text { Andre } \\
\text { mat- } \\
\text { varer }\end{array}$ & $\begin{array}{r}\text { Klær, } \\
\text { sko }\end{array}$ & $\begin{array}{r}\text { Møbler } \\
\text { m.m. }\end{array}$ & $\begin{array}{r}\text { Hus- } \\
\text { holdn. } \\
\text { apparater }\end{array}$ \\
\hline Dange & 161 & 174 & 155 & 168 & 157 & 146 & 107 & 190 & 131 & 110 & 114 \\
\hline Finland & 119 & 118 & 121 & 152 & 117 & 111 & 128 & 165 & 139 & 99 & 115 \\
\hline Sverige & 118 & 112 & 119 & 123 & 126 & 120 & 110 & 116 & 126 & 103 & 116 \\
\hline Irland & 118 & 121 & 105 & 120 & 126 & 106 & 108 & 139 & 109 & 105 & 101 \\
\hline Frankrike & 116 & 100 & 131 & 112 & 127 & 110 & 115 & 109 & 110 & 104 & 108 \\
\hline Belgia & 114 & 112 & 126 & 115 & 108 & 114 & 111 & 107 & 106 & 106 & 105 \\
\hline Tyskland & 102 & 97 & 106 & 102 & 105 & 103 & 126 & 98 & 99 & 96 & 102 \\
\hline Nederland & 101 & 102 & 123 & 90 & 102 & 94 & 102 & 90 & 106 & 104 & 97 \\
\hline UK & 93 & 92 & 95 & 87 & 98 & 91 & 80 & 99 & 93 & 99 & 97 \\
\hline EU-28 & 100 & 100 & 100 & 100 & 100 & 100 & 100 & 100 & 100 & 100 & 100 \\
\hline
\end{tabular}

Kilde: Eurostat. Hentet fra statistikkbanken til Statistisk sentralbyrå (https://www.ssb.no/priser-og-prisindekser).

En første observasjon er at Norge har betydelig høyere matvarepriser (unntatt fisk) enn nordeuropeiske land som kan handle fritt seg imellom. For eksempel er norske matpriser 61 prosent høyere enn gjennomsnittet i EU, og 36 prosent høyere enn i Sverige og Finland. Tabell 6 viser at prisforskjellen mot Sverige (tilsvarende gjelder mot Finland) utgjør en årlig merutgift for norske forbrukere på 37 milliarder kroner. Siden skjermingsstøtten til norske bønder «bare» utgjør om lag 10 milliarder av dette beløpet, kan 27 milliarder tilskrives høyere marginer eller påslag videre nedover i verdikjeden.

Vi legger deretter merke til at prisforskjellene er spesielt høye for bearbeidede næringsmidler ( Andre matvarer»). Her er forbrukerprisene $90 \%$ høyere enn gjennomsnittet i EU, og om lag $64 \%$ høyere enn i Sverige og Finland. For bearbeidede matvarer utgjør prisforskjellen mot Sverige og Finland en årlig merutgift på om lag 14 milliarder kroner. Etter intensjonen skal det være fri konkurranse mellom norsk og europeisk næringsmiddelindustri for bearbeidede næringsmidler, enten ved at det kompenseres for nasjonale forskjeller i råvarepriser eller ved at varene 
ikke beskyttes mot import. De store prisforskjellene kan imidlertid vanskelig forklares på annen måte enn at det er konkurranseproblemer i verdikjeden.

En tredje observasjon er at detaljvarer som ikke omsettes gjennom dagligvarebutikker og som heller ikke møtes med særlig importvern i Norge, som møbler, husholdningsapparater, klær og sko, stort sett ligger på samme prisnivå som i våre nordiske naboland. Dette er som forventet for verdikjeder som typisk omsetter frihandelsvarer.

Tabell 6 Prisforskjellene mellom Norge og Sverige omregnet til merutgifter for norske forbrukere (beløp i milliarder kroner).

\begin{tabular}{|l|r|r|r|r|}
\hline & $\begin{array}{r}\text { Relativ } \\
\text { prisforskjell } \\
\text { (Norge/Sverige) }\end{array}$ & $\begin{array}{r}\text { Norske } \\
\text { forbruksutgifter }\end{array}$ & $\begin{array}{r}\text { Verdi av norsk } \\
\text { forbruksvolum til } \\
\text { svensk pris }\end{array}$ & $\begin{array}{r}\text { Merutgifter } \\
\text { for norske } \\
\text { forbrukere }\end{array}$ \\
\hline Andre matvarer & 1,64 & 35,4 & 21,7 & 13,8 \\
\hline Kjøtt & 1,30 & 28,1 & 21,7 & 6,5 \\
\hline $\begin{array}{l}\text { Frukt, grønt, } \\
\text { potet }\end{array}$ & 1,25 & 25,7 & 20,7 & 5,1 \\
\hline Melk, ost, egg & 1,55 & 22,1 & 14,3 & 7,8 \\
\hline $\begin{array}{l}\text { Brød og } \\
\text { kornvarer }\end{array}$ & 1,36 & 17,3 & 12,7 & 4,6 \\
\hline Fisk & 0,97 & 8,6 & 8,9 & $-0,2$ \\
\hline Oljer og fett & 1,21 & 2,3 & 1,9 & 0,4 \\
\hline Matvarer totalt & $\mathbf{1 , 3 6}$ & $\mathbf{1 3 9 , 7}$ & $\mathbf{1 0 2 , 5}$ & $\mathbf{3 7 , 2}$ \\
\hline
\end{tabular}

Kilde: Eurostat (https://ec.europa.eu/eurostat/statisticsexplained/index.php/ Comparative_price_levels_of_consumer_goods_and_services).

Et første steg for å øke konkurransen i verdikjeden vil være å redusere tollsatsene på jordbruksvarer så mye at det faktisk kommer import innenfor alle produktkategorier. Det er i tillegg viktig å rette inn særskilte konkurransepolitiske tiltak mot markedet for bearbeidede næringsmidler, som er kjennetegnet ved spesielt høye prispåslag i verdikjeden sammenlignet med EU-land som kan handle fritt seg imellom. Handelen med bearbeidede næringsmidler krever nettverk og bedriftsspesifikke relasjoner som det er kostbart å etablere i et annet land. For å redusere terskelen for utenlandske merkevareleverandører er det viktig å fjerne ordninger som skaper unødige handelskostnader, som for eksempel RÅK-ordningen. 
Slike tollreduksjoner vil utsette norsk matindustri for konkurranse, og dagligvarekjedene vil få reelle utsidealternativ. På leverandørsiden vil bøndene og matindustrien få kraftige insentiver til å differensiere sine varer gjennom produktutvikling og merkevarebygging. Samtidig vil konkurransen virke effektivitetsfremmende, for eksempel gjennom strukturtiltak og mer effektive samarbeidsformer i kjeden. På sluttleddet vil importmuligheter svekke den viktigste etableringshindringen for utenlandske dagligvarekjeder. I tillegg kan en forvente mer like konkurransevilkår mellom dagens dagligvarekjeder.

Fra økonomisk velferdsteori finnes det ingen vektige argumenter for å beskytte den jordbruksbaserte verdikjeden med importvern. Fellesgoder knyttet til jordbruksaktivitet, som kulturlandskap, miljøgoder og matvaresikkerhet, kan sikres både billigere og bedre med mer målrettede virkemidler. Direkte tilskudd er også et mer effektivt virkemiddel for å oppfylle næringspolitiske målsettinger i jordbruket enn importvern og konkurransebegrensninger. Tilskuddene kan rettes direkte mot politiske mål eller fellesgoder og slik redusere det samlede støttebehovet. I tillegg har skattefinansierte tilskudd en bedre fordelingsprofil enn markedsprisstøtte.

Takk til Teis Lunde Lømo, Arne Melchior, Klaus Mittenzwei, Ivar Pettersen, Frode Steen og Erling Vårdal for gode kommentarer. Forfatteren står selv ansvarlig for analyse og konklusjoner. 


\section{Referanser}

Balassa, B. (1964). The purchasing-power parity doctrine: A reappraisal. Journal of Political Economy, 72(6), 584-596. https://doi.org/10.1086/258965

Baumol, W. J., Panzar, J. C. \& Willig, R. D. (1982). Contestable markets and the theory of industry structure. New York: Harcourt Brace Jovanovich.

Bernard, A. B., Jensen, J. B., Redding, S. J. \& Schott, P. K. (2007). Firms in international trade. Journal of Economic Perspectives, 21(3), 105-130. http://doi.org/ 10.1257/jep.21.3.105

Bhagwati, J. N. (1965). On the equivalence of tariffs and quotas.

I Richard E. Baldwin (Red.), Trade, growth and the balance of payments - essays in honor of G. Haberler (s. 53-67). Chicago: Rand McNally.

Brunstad, R. J., Gaasland, I. \& Vårdal, E. (2005). Multifunctionality of agriculture: An inquiry into the complementarity between landscape preservation and food security. European Review of Agricultural Economics, 32(4), s. 469-488. https://doi.org/10.1093/erae/jbio28

Budsjettnemnda for jordbruket. (2019a). Utredning $n r$. 3. Resultatkontrollen for gjennomføring av landbrukspolitikken (Grunnlagsmateriale til jordbruksforhandlingene; UT-2012-3). Hentet fra http://hdl.handle. net/11250/2464862

Budsjettnemnda for jordbruket. (2019b). Totalkalkylen for jordbruket. Jordbrukets totalregnskap 2017 og 2018. Budsjett 2019 (Totalkalkylen for jordbruket). Hentet fra http://hdl.handle.net/11250/2608551

Chamberlin, E. (1933). The theory of monopolistic competition: A reorientation of the theory of value. Cambridge, Mass.: Harvard University Press.

Corden, W. M. (1971). The substitution problem in the theory of effective protection. Journal of International Economics, 1(1), 37-57. https://doi.org/10.1016/0022-1996(71)90015-8

Drake, L. (1992). The non-market value of Swedish agricultural landscape. European Review of Agricultural Economics, 19(3), 51-364. https://doi.org/10.1093/erae/19.3.351

Evans, C. L. (2003). The economic significance of national border effects. The American Economic Review, 93(4), 1291-1312. https://doi.org/ 10.1257/ooo282803769206304

Foros, Ø. \& Kind, H. J. (2018). Asymmetriske innkjøpspriser i dagligvaremarkedet. En vurdering av konsekvensene av et forbud mot prisdiskriminering fra dominerende leverandører (Rapport skrevet på oppdrag fra Rema 10oo). Hentet fra 
https://www.nhosh.no/contentassets/b3e107a9593e4b9c9285ofbod9a318ao/ 8033315_1_foros-kind-asymmetriske-innkjopspriser.pdf

Friberg, R., Pettersen, I., Steen, F. \& Ulsaker, S. A. (2020). Annerledeslandet Norge: butikktilgjengelighet og markedskonsentrasjon i Sverige og Norge. I F. Steen \& I. Pettersen (Red.), Mot bedre vitende i norsk matsektor (Kap. 2, s. 35-70). Oslo: Cappelen Damm Akademisk.

Gaasland, I. (2011). Jordbrukspolitikk, matvarepriser og vareutvalg. I I. Pettersen \& T. Gabrielsen (Red.), Dagligvarehandel og mat 2011. Perspektiver på verdikjedene for matvarer (NILF Rapport, s. 67-86). Oslo: Norsk institutt for landbruksøkonomisk forskning.

Gaasland, I. (2015). Fisk og jordbruk - hvem definerer Norges interesser? I A. Melchior \& U. Sverdrup (Red.), Interessekonflikter i norsk handelspolitikk (s. 35-58). Oslo: Universitetsforlaget.

Gabrielsen, T. S, Moen, E. R. \& Nilssen, T. (2020). Utredning om prisdiskriminering i dagligvarebransjen (Rapport, Nærings- og fiskeridepartementet). Hentet fra https://www.regjeringen.no/contentassets/deac14c2eeef 432487543fa5f7dedab5/ prisdiskriminering_170120.pdf

Galbraith, J. K. (1952). American capitalism: The concept of countervailing power. Boston: Houghton Mifflin.

Hjelmeng, E. J. \& Sørgard, L. (2014). Konkurransepolitikk: Rettslig og økonomisk analyse. Bergen: Fagbokforlaget.

Joskow, P. L. (2008). Vertical integration. I C. Ménard \& M. M. Shirley (Red.), Handbook of new institutional economics (s. 319-348). https://doi.org/10.1007/978-3-540-69305-5_14

Kreps, D. M. \& Scheinkman, J. A. (1983). Quantity precommitment and Bertrand competition yield Cournot outcomes. The Bell Journal of Economics, 14(2), 326337. https://doi.org/ 10.2307/3003636

Krugman, P. R., Obstfeld, M. \& Melitz, M. (2018). International economics: Theory and policy (11. utg.). Essex: Pearson.

Konkurransetilsynet. (2019). Kartlegging av innkjøpsbetingelser $i$ norsk dagligvaresektor (Rapport 2019). Hentet fra https://konkurransetilsynet.no/wpcontent/uploads/2019/11/Rapport-om-innkj\%C3\%B8psbetingelser_2019.pdf

Inderst, R. \& Valetti, T. M (2011). Buyer power and the 'waterbed effect'. The Journal of Industrial Economics, 59(1), 1-20. https://doi.org/10.1111/j.1467-6451.2011.00443.x

Landbruksdirektoratet. (2019a). Omverdenen til norsk landbruk og matindustri. Rapport for 2018 (Rapport nr. 2/2019). Hentet fra https://www. landbruksdirektoratet.no/no/produksjon-og-marked/egg/marknad-og-pris/ publikasjonar/_attachment/73785?_ts=16952849330\&download=true

Landbruksdirektoratet. (2019b). Markedsrapport 2018. Vurdering av markedene for norske landbruksvarer (Rapport nr. 3/2019). Hentet fra 
https://www.landbruksdirektoratet.no/no/dokumenter/publikasjoner/_ attachment/73784?_ts=1695282ed5o\&download=true

McCallum, J. (1995). National borders matter: Canada-U.S. regional trade patterns. American Economic Review, 85(3), 615-623. Hentet fra www.jstor.org/ stable/2118191

Mageli, H. (2015, 17. mars). Bør importvernet fjernes? Dagligvarehandelen.

Melitz, M. J. (2003). The impact of trade on intra-industry reallocations and aggregate industry productivity. Econometrica, 71(6), 1695-1725.

https://doi.org/10.1111/1468-0262.00467

Neary, P., Maggi, G. \& Mrazova, M. (2018). Choked by red tape? The political economy of wasteful trade barriers. Economics Series Working Papers 847. University of Oxford: Department of Economics.

NOU 2011:4. (2011). Mat, makt og avmakt - om styrkeforholdene i verdikjeden for mat. Oslo: Landbruks- og matdepartementet.

NOU 2015:1. Produktivitet - grunnlag for vekst og velferd Produktivitetskommisjonens første rapport. Oslo: Finansdepartementet.

Oslo Economics. (2017). Etableringshindringer i dagligvaresektoren (Rapport utarbeidet på oppdrag fra Nærings- og fiskeridepartementet, 2017-46). Hentet fra https://osloeconomics.no/wp-content/uploads/Etableringshindringer-idagligvaresektoren_ref2.pdf

Pepall, L., Richards, D. \& Norman, G. (2014). Industrial organization. Contemporary theory and empirical applications (5. utg.). Hoboken, NJ: Wiley.

Peterson, J. M., Boisvert, R. N. \& de Gorter, H. (2002). Environmental policies for a multifunctional agricultural sector in open economies. European Review of Agricultural Economies, 29(4), 423-443. https://doi.org/10.1093/eurrag/29.4.423

Pettersen, I. (Red.).(2013). Dagligvarehandel og mat 2013. Oslo: Norsk institutt for landbruksøkonomisk forskning. Hentet fra https://nnn.no/wp-content/ uploads/2013/11/DagligvarehandelOgMat2013.pdf

Rauch, J. (1999). Networks versus markets in international trade. Journal of International Economics, 48(1), 7-35. https://doi.org/10.1016/Soo221996(98)0ooo9-9

Salinger, M. (1988). Vertical mergers and market foreclosure. The Quarterly Journal of Economics, 103(2), 345-356. https://doi.org/10.2307/1885117

Samuelson, P. A. (1964). Theoretical notes on trade problems. The Review of Economics and Statistics, 46(2), 145-154. http://doi.org/10.2307/1928178

Tirole, J. (1988). The theory of industrial organization. Cambridge, MA: The MIT Press. 


\title{
Hvordan bygge sterke merkevarer med norsk identitet i dagligvarehandelen?
}

\section{Magne Supphellen}

Norges Handelshøyskole (NHH)

\begin{abstract}
Norwegian consumers tend to prefer Norwegian food products to imports. However, in order fully to exploit this preference, it is not sufficient to use Norwegian brand names or put a generic label with the Norwegian flag on the package. Food producers should integrate origin associations in the positioning of brands according to their specific characteristics and history. In this chapter, we offer some practical guidelines on how to do this.

Secondly, we evaluate two generic food brands, designed to stimulate the turnover of Norwegian food products: NytNorge and Matprat. For both brands, there is a need for more advanced measurement of effects. Evaluations of available data suggest that Matprat is effective and profitable, whereas NytNorge is not. A simulated store experiment showed no significant effects of NytNorge on choice of food products.
\end{abstract}

Keywords: generic marketing, generic labeling, country-of-origin effects, food labeling

Sitering av denne artikkelen: Supphellen, M. (2020). Hvordan bygge sterke merkevarer med norsk identitet i dagligvarehandelen? I F. Steen \& I. Pettersen (Red.), Mot bedre vitende i norsk matsektor (Kap. 6, s. 193-214). Oslo: Cappelen Damm Akademisk. https://doi.org/10.23865/noasp.93.ch6 Lisens: CC BY-ND 4.0. 


\section{Introduksjon}

Merkevarers potensial for verdiskaping knytter seg til tre hovedfaktorer: Kundenes kunnskap om merket (assosiasjonene), hvor langt fremme i hukommelsen merket ligger i forhold til konkurrentene (merkekjennskap) og hvor innarbeidet merkevaren er i kundenes handlevaner (Keller, 2012). Vi skal her konsentrere oss om den første faktoren, merkekunnskap, det vil si de assosiasjonene som knytter seg til merkevaren. Disse bør være konsistente, relevante og dels differensierende i forhold til konkurrentene. Merker som utvikler et tydeligere, mer positivt og differensierende meningsinnhold vil oftere bli valgt av kundene og derved styrke bedriftens inntekter og markedsverdi (Keller, 2012; Mizik \& Jacobson, 2008, 2009; Rego, Billett \& Morgan, 2009).

Et nøkkelspørsmål i all merkevarbygging er derfor hvilke assosiasjoner som bør knyttes til merkevaren for å gjøre den maksimalt attraktiv for kundene. Hvilke assosiasjoner som dannes, kan i stor grad styres av bedriften. En aktuell mulighet er å knytte merket til et kjent geografisk område, f.eks. et land (Norge), en region (Hardanger), eller en by (Trondheim). Hensikten vil være å utnytte spesifikke positive assosiasjoner som knytter seg til disse områdene. Vi kaller slike geografiske referanser for opphavsassosiasjoner (OA). Mange norske matvareprodukter benytter seg av denne strategien, og forskningslitteraturen viser at dette kan være en meget effektiv strategi (Koschate-Fischer, Diamonopoulos \& Oldenkotte 2012). I dette kapittelet skal vi se nærmere på hva som skal til for å lykkes med en norsk OA-strategi.

Et særpreg med OA-strategien er at den dels baseres på produktmerkenes egen merkevarebygging (f.eks. Gildes posisjonering) og dels på bruken av generiske virkemidler, det vil si felles tiltak for å holde oppe omsetningen av norske matvareprodukter. Vi skal konsentrere oss om to hovedaktører innen generisk markedsføring av norske matvarer: Matprat og NytNorge. Spørsmålet er om disse ordningene er effektive. Bidrar de reelt til å styrke preferansen for produktmerker med norsk identitet?

Første del av kapittelet handler om hvordan man kan lykkes med merkevarbygging som inkluderer OA. Som grunnlag for denne diskusjonen, gjør vi først kort rede for hvordan vi definerer en effektiv 
merkeposisjonering. Dette må til for å etablere en ramme for hvordan merkekunnskap (inklusive OA) bør bygges. Diskusjonen i andre del av kapittelet handler om hvorvidt Matprat og NytNorge gir effektiv drahjelp for merkevarer med en norsk OA-strategi.

\section{Merkeposisjonering: Målbildet for merkekunnskapen}

For å kunne arbeide rasjonelt med å bygge attraktiv merkekunnskap er det nødvendig med et tydelig målbilde; det vil si en spesifisering av målsatte assosiasjoner for merkevaren. Det er dette som kalles merkets posisjonering. De målsatte assosiasjonene bør dreie seg om forhold som er viktige for kundene. Noen av dem bør være differensierende i forhold til konkurrentene, og disse bør være godt forankret i bedriftens strategiske ressurser (Park, Jaworski \& MacInnis, 1986; Supphellen, 2014). Som eksempel skal vi se nærmere på merkevaren Nordfjordkjøtt.

Før innholdet i målsatt nettverk kan avklares, må kategorien og målgruppen defineres. Nordfjordkjøtt er i hovedsak kjøttprodukter til hverdagsbruk, primært til middag og pålegg. I hverdagen søker folk flest etter enkle, rimelige og lett tilgjengelige matvarer med tilfredsstillende kvalitet. Hovedmålgruppen er nettopp «folk flest»: Prisbevisste forbrukere med en positiv holdning til kjøttmat og med ansvar for å handle inn til husholdningen.

En aktuell (fiktiv) posisjonering for Nordfjordkjøtt er illustrert i figur 1. Målbildet er et enkelt assosiasjonsnettverk, beskrevet slik man ønsker at merkevaren skal oppfattes av kundene. De første assosiasjonene som knyttes til merket er sentrale nytteassosiasjoner, det vil si assosiasjoner som beskriver hvilket utbytte kunden har av å bruke merket (Keller, 2012). Tre typer nytte er særlig viktige i kategorien kjøttprodukter til hverdagsbruk: At produktene smaker godt, har god kvalitet og en «grei pris». På neste nivå ligger de sekundære assosiasjonene, som definerer meningsinnholdet i nytteassosiasjonene. De sekundære sier noe om hvordan eller hvorfor Nordfjordkjøtt gir kunden de tre formene for nytte. Det er sjelden at enkeltassosiasjoner kan differensiere et merke. Som regel 
må flere assosiasjoner kombineres. For Nordfjordkjøtt kan vi tenke oss at kombinasjonen med «greie priser» og "god kvalitet», støttet av assosiasjoner til Vestlandet, vil kunne differensiere merket. Smaksopplevelsen skal være på nivå med konkurrentene i kategorien (i paritet). Her har ikke Nordfjordkjøtt forutsetninger for å differensiere seg over tid, men må være på nivå med konkurrentene for at differensieringen skal gi uttelling.

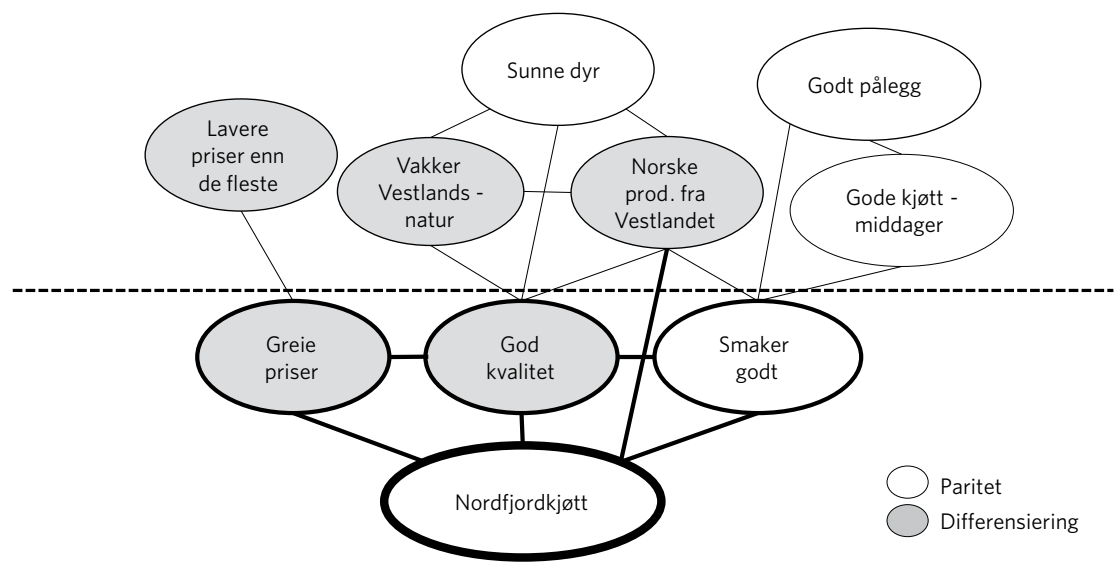

Figur 1 Merkeposisjonering for Nordfjordkjøtt (forfatterens illustrasjon). Assosiasjoner i grått er differensieringsfaktorer, de øvrige er paritetsfaktorer.

Merkeposisjoneringer slik den vi har beskrevet i figur 1 er nyttige i arbeidet med å bygge sterke merkevarer. Det målsatte nettverket gir fokus på de viktigste elementene i kundens nytteopplevelse og klargjør hva merket skal skille seg ut på. Det gir også en ramme for kommunikasjon og innovasjon som sikrer en tydelig merkevare over tid, samtidig som utvalgte deler av nettverket kan vektlegges i enkeltkampanjer for å oppnå tilstrekkelig presisjon.

Det sentrale spørsmålet i vår sammenheng er hvordan opphavsassosiasjoner (OA) kan eller bør inkluderes i slike posisjoneringer. I eksempelet med Nordfjordkjøtt er assosiasjonene til Vestlandet knyttet til kvalitet og smak. Dette er bare én av mange muligheter. I det følgende bretter vi ut disse mulighetene og diskuterer prinsipielt hvordan opphav kan utnyttes for å styrke merkevaren. 


\section{Hvordan kan norsk opphav styrke merkevaren?}

Forskning på opphavseffekter viser at opphavsassosiasjoner (OA) kan påvirke merkepreferanser på minst fem forskjellige måter (Hong \& Wyer, 1989; Li \& Wyer, 1994).

For det første kan opphav fungere som en generell tommelfingerregel (heuristikk). I slike tilfeller fungerer opphavsassosiasjonen som eneste basis for beslutningen. I områder av Spania hvor det er mange norske turister, er det ikke uvanlig at butikker fører enkelte norske matvarer. Her vil nok en del sette pris på å finne norske varer og kjapt velge disse uten nærmere overveielse. I den hjemlige handelen vil noen kunne velge frukt på samme måte - de velger den norske. For de fleste matvarekategoriene er imidlertid denne mekanismen mindre relevant. Flere ting vil spille inn enn opphavet, og opphavsinformasjonen vil kunne påvirke vurderingen på ulike måter.

Andre ganger kan opphav fungere som en sammenligningsstandard i etterkant av kjøpet. Dette skjer når man oppdager eller lærer om opphavet etter kjøpet. I slike tilfeller kan opphavsinformasjonen bli brukt som grunnlag for vurdering av produktopplevelsen: «Dette var norske epler på sitt beste», eller «Til å være norske, var de litt spesielle på smaken».

For det tredje kan opphav fungere som en selvstendig egenskap ved produktet i tillegg til andre egenskaper. Det vil si at forbrukeren vurderer en rekke egenskaper som smak, kvalitet, sunnhet osv., og blant disse egenskapene inngår også norsk opphav. Denne mekanismen er særlig relevant for kundegrupper med stor interesse og kunnskap for produktene. Slike forbrukere har en tendens til å ta utgangspunkt i enkeltegenskaper når de vurderer alternativer. Mekanismen er også spesielt relevant for merkevarer som vektlegger funksjonell nytte, det vil si produktenes problemløsende egenskaper (f.eks. unngå sukker, tilføre proteiner for å bygge muskler, etc.). Funksjonelle merker vurderes oftere på egenskapsnivå enn merker med fokus på sensorisk nytte (f.eks. smak, nytelse, eller kognitiv stimulans). Sistnevnte evalueres oftere på et overordnet (holistisk) nivå, og emosjoner spiller en større rolle (Botti \& McGill, 2011).

Den fjerde typen opphavseffekt er halo-effekten. I dette tilfellet vekker opphavsinformasjonen emosjoner som farger vurderingen av alle 
egenskapene, positivt eller negativt (Han, 1989). Eksempelvis kan gode følelser for Norge og norsk landbruk føre til oppvurderinger av alle egenskaper ved Jarlsberg. Motsatt kan kunnskapen om at en biff kommer fra Usbekistan gjøre forbrukeren utrygg og svekke vurderingen av alle egenskaper ved produktet. Halo-effekten er mer fremtredende for sensoriske merkevarer (holistisk vurdering) og for konsumenter med lav produktkunnskap, som stoler mindre på egne vurderinger av produktegenskaper.

Den femte og siste mekanismen dreier seg om opphavsinformasjon som egenskaps-signal. Flere studier viser at opphav kan brukes som grunnlag for å utlede informasjon om spesifikke egenskaper ved produktet (Hong \& Wyer, 1989). Her kommer eksempelet med Nordfjordkjøtt inn i bildet (figur 1). I dette eksempelet fungerer det vestlandske opphavet som et signal om god kvalitet og smak. Denne mekanismen er særlig relevant for kundegrupper som har god kunnskap om både produktet og opphavet.

Gjennomgangen viser at opphavsinformasjon kan påvirke produktvurderinger på ulike måter. Kobler vi denne innsikten med rammeverket for merkeposisjonering, kan vi gi noen retningslinjer for hvordan matvareindustrien og handelen kan gå frem for å bygge merkevarer med norsk identitet. Vi fokuserer på hvordan opphavsassosiasjoner kan integreres i målbildet for merkevaren (posisjoneringen).

\section{Retningslinjer for utvikling av merkevarer med norsk identitet i dagligvarehandelen}

Skal en merkevare gis en tydelig norsk identitet, må norske opphavsassosiasjoner (OA) integreres i målbildet for merkevaren. Her følger noen praktiske retningslinjer for hvordan dette kan gjøres.

Grunnlaget for vurderingen av hvordan opphav kan integreres er tre typer innsikt. I første omgang må vi forstå hvilke assosiasjoner som knytter seg til vår merkevare og konkurrentenes merkevarer i utgangspunktet, samt hvilke former for nytte som driver merkepreferansene (Keller, 2012). Dette gir oss et detaljbilde av merkevarens stilling i dag, med styrker og svakheter i forhold til de viktigste formene for nytte. OA kan være en del av dette bildet, eller helt fraværende. 
For det andre trengs innsikt om hvilke (nye) opphav som kan knyttes til merkevaren (Norge, Vestlandet, Lofoten, etc.) og hvilke kategoribetingede assosiasjoner slike opphav aktiverer. I eksempelet med Nordfjordkjøtt er det ikke tilstrekkelig å vite hva folk assosierer med Vestlandet generelt; vi må også vite noe om hva de assosierer med mat/kjøtt fra Vestlandet. Denne typen innsikt bidrar til å brette ut mulighetsrommet for bruk av OA i merkevarebyggingen.

Den tredje typen innsikt dreier seg om mekanismene for bruk av OA i beslutningsprosessen. Dersom OA er til stede i nettverket for merkevaren, bør man teste hvilken rolle OA spiller inn mot de faktorene som driver preferansene (i vårt eksempel vil vi teste om assosiasjoner til Vestlandet reelt påvirker smaken og kvaliteten, jf. figur 1). Alle de fem mekanismene vi diskuterte ovenfor bør testes i slike analyser.

Hvis OA ikke finnes for egen merkevare, kan man gjøre tilsvarende analyser for andre merker som har OA, eller gjøre enkle eksperimenter med kommunikasjonskonsepter som gjenspeiler de mest aktuelle mekanismene. Hensikten er å få innsikt i hvordan kundene naturlig bruker OA i vurderinger av merkevarene. Fungerer OA som selvstendig egenskap eller i samspill med andre egenskaper, som i eksempelet med Nordfjord? Ser vi spor av halo-effekter?

Til sammen gir disse tre formene for innsikt et grunnlag for å vurdere om (nye) OA skal integreres i målbildet, samt hvordan dette kan og bør gjøres. OA bør bare tas inn dersom de, med grunnlag i analysene, kan forventes å påvirke merkepreferansen direkte eller indirekte. Det kan skilles mellom fire typer tilpasninger:

1. OA legges inn som selvstendig driver på primærnivå i målbildet, eksempelvis som nytteassosiasjon ved siden av «smak», «kvalitet» og «grei pris» for Nordfjordkjøtt (se figur 1).

2. OA integreres i målbildet på sekundært nivå og gis rollen som støtteassosiasjoner for drivere på primærnivå i posisjoneringen, slik Vestlandsassosiasjonene støtter «god smak» og «god kvalitet» for Nordfjordkjøtt (se figur 1).

3. OA gis en mer perifer rolle på tertiærnivå (nivå 3) som støtte for andre assosiasjoner på sekundært nivå. I figur 1 kan vi tenke oss at 
vi bak assosiasjonene «gode kjøttmiddager» og «godt pålegg» la inn opphavsassosiasjonen «norske tradisjoner».

4. Kombinasjoner av 1-3.

Et femte alternativ er selvsagt å holde OA helt utenfor posisjoneringen.

For å hente ut potensialet som ligger i OA, er det avgjørende at nye OA, eller nye måter å integrere etablerte OA på, vurderes og testes ut. Begrenses analysen til etablerte OA og kjente effekter i historiske data, kan man gå glipp av nye og mer effektive alternativer til posisjonering av merkevaren. Slike nye muligheter avdekkes best gjennom eksperimenter hvor man tester ut serier av budskap som representerer ulike OA-tilpasninger.

Vi vet lite om hvordan norsk industri og handel jobber i praksis med å utnytte potensialet i norske OA. Med utgangspunkt i det vi ser av markedskommunikasjon på TV, aviser, internett og i andre kanaler, er det grunn til å anta at mange har et betydelig forbedringspotensial. Det er få norske produktmerker som tydelig og systematisk spiller på OA i kommunikasjonen. I stedet overlater mange OA-kommunikasjonen til den generiske merkeordningen NytNorge og opplysningskontorenes generiske markedsføring av norsk mat. Neste spørsmål er om dette er en effektiv strategi.

\section{Får merkevarer med norsk identitet effektiv drahjelp av NytNorge og Matprat?}

I tillegg til kommunikasjonen for enkeltmerker som Gilde, Tine, Nordfjordkjøtt o.a., finner vi i Norge (og i mange andre land) to typer generisk kommunikasjon som har til hensikt å styrke produktenes nasjonale identitet og stimulere omsetningen av norske matvareprodukter. Begrepet generisk kommer av latinske genus eller gener - og betyr art, type eller kategori. Formålet med norsk generisk markedsføring er å øke totalomsetningen for visse matkategorier produsert i Norge (f.eks. kylling eller egg). Reklamen fokuserer på kategorien, ikke spesifikke merkevarer, og skal etter hensikten ikke påvirke markedsandelene for produsentene innen kategorien (Crespi \& Sexton, 2013). 
I Norge har vi for det første opplysningskontorer som driver både med faktaformidling om norske matvarer samt aktiv påvirkning med hensikt å stimulere etterspørselen på kategorinivå. Vi skal se nærmere på Matprat, tidligere Opplysningskontoret for kjøtt og egg. For det andre har vi merkeordningen NytNorge, som forvaltes av stiftelsen Matmerk. NytNorge er et merke som har til hensikt å «hjelpe folk å velge norsk» i butikken. Norsk industri og handel betaler en avgift for å bruke NytNorge-merket på emballasjen.

Matprat og NytNorge har dels overlappende formål (styrke omsetningen av norske matvarer), men ulike roller. Fungerer ordningene etter hensikten? Er de lønnsomme? Vi begynner med Matprat.
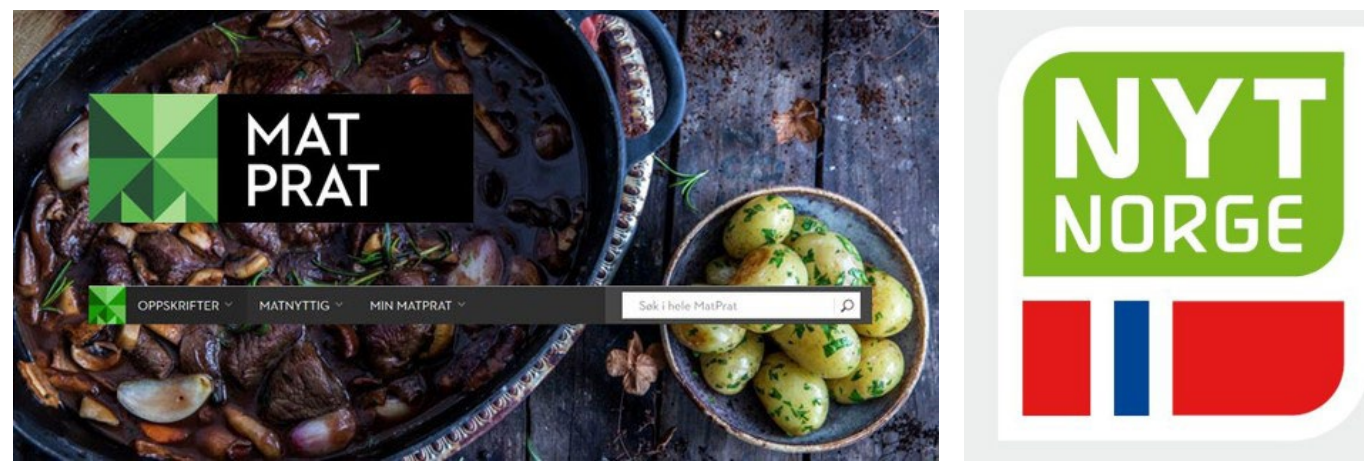

Bilde 1. To generiske virkemidler: Matprat og NytNorge-merket.

\section{Matprat: Økt attraktivitet og omsetning på kategorinivå?}

Hovedmotivasjonen bak generisk markedsføring er knyttet til antagelsen om at mange matprodukter er relativt homogene. Den enkelte produsent har da svake insentiver tilå bruke penger på reklame, fordi konkurrentene vil høste den samme effekten uten å betale for den («free-riding»). Konsekvensen av manglende insentiver blir lav reklameintensitet og svekket konkurransekraft for kategorien samlet sett. For å øke reklameintensiteten og styrke omsetningen etableres derfor programmer hvor næringen 
går sammen om felles generisk reklame for kategorien, som regel finansiert via en liten omsetningsavgift (typisk under $1 \%$ av omsetningen).

Reklamebegrepet omfatter i denne sammenheng mange typer kommunikasjonsaktiviteter i ulike kanaler: Internett, TV, radio, aviser, ukeblader og utendørsreklame, samt PR, sponsing, rabattkuponger (særlig i USA/Australia), sponsing og sisteledds-reklame i butikk.

Generiske markedsføringsprogrammer er vanlige i mange land. I Norge er Sjømatrådet ansvarlig for generisk markedsføring av norsk sjømat i eksportmarkedene, mens opplysningskontorene forvalter ansvaret for den generiske markedsføringen av norske kjøtt- og jordbruksprodukter i det norske markedet. Matprat har som nevnt ansvar for den generiske markedsføringen av kjøtt og egg. Ifølge årsrapportene har budsjettene ligget $\mathrm{i}$ intervallet 70-79 millioner de siste årene. Om lag 40-46 millioner er brukt på generisk markedsføring (Matprat har også andre oppgaver). Inntektene kommer fra en omsetningsavgift på bøndenes salg av kjøtt og egg til industrien. Har Matprats aktiviteter vært lønnsomme?

Vi er kjent med at Matprat arbeider med å utvikle en modell for økonometriske lønnsomhetsberegninger. Før denne modellen tas i bruk, må en lønnsomhetsvurdering baseres på analyser av lignende aktiviteter i andre land samt grove overslag. Konklusjonene vil ha en foreløpig karakter, og må etterprøves når modellen og datagrunnlaget er på plass.

\section{Virker generisk markedsføring?}

For å gi et foreløpig svar på dette spørsmålet, skal vi se nærmere på hovedfunn i den internasjonale forskningslitteraturen på effekter av generisk matreklame. Tyngden av denne forskningen er amerikansk. Hovedgrunnen til dette er at USA var tidlig ute med generiske kampanjer (1920-årene), og siden har det vært brukt store beløp årlig på denne typen markedsføring. Satsingen har også inkludert registrering av kostnader og omsetningstall, og med dette skapt et solid datagrunnlag for analyse av effekter. Vi har imidlertid også relevant forskning basert på data fra Canada, Storbritannia og Australia. I Norge har vi noe dokumentasjon på effekter av generisk markedsføring av norsk sjømat i eksportmarkedene. Siden vårt fokus er rettet mot innenlands generisk markedsføring av 
kjøtt- og jordbruksprodukter, vil vi ikke gå gjennom disse analysene her. Det er likevel verdt å nevne at flere analyser viser at den generiske reklamen for norsk sjømat har vært meget lønnsom (se Kaiser, 2015; Myrland, Emaus, Roheim \& Kinnucan, 2004).

Ulike tilnærminger er benyttet i analysene av effekter i forskningslitteraturen. De fleste studiene er basert på økonometriske analyser av tidsseriedata og har til hensikt å teste om inntektseffekten av en generisk kampanje overstiger kostnaden. De fleste av disse studiene rapporterer Average Benefit Cost Ratio (ABCR), det vil si det gjennomsnittlige forholdet mellom inntektseffekten og kostnaden i den aktuelle perioden. Så lenge ABCR er større enn 1, er inntektseffekten større enn kostnaden og markedsføringen lønnsom. Mange rapporterer også Marginal BenefitCost Ratio (MBCR), det vil si benefit-cost ratioen for en marginal økning i kostanden. Dersom MBCR er større enn 1, vil det være lønnsomt å utvide kampanjen og bruke mer penger fordi inntektseffekten av de ekstra kronene overstiger kostnaden (se figur 2).

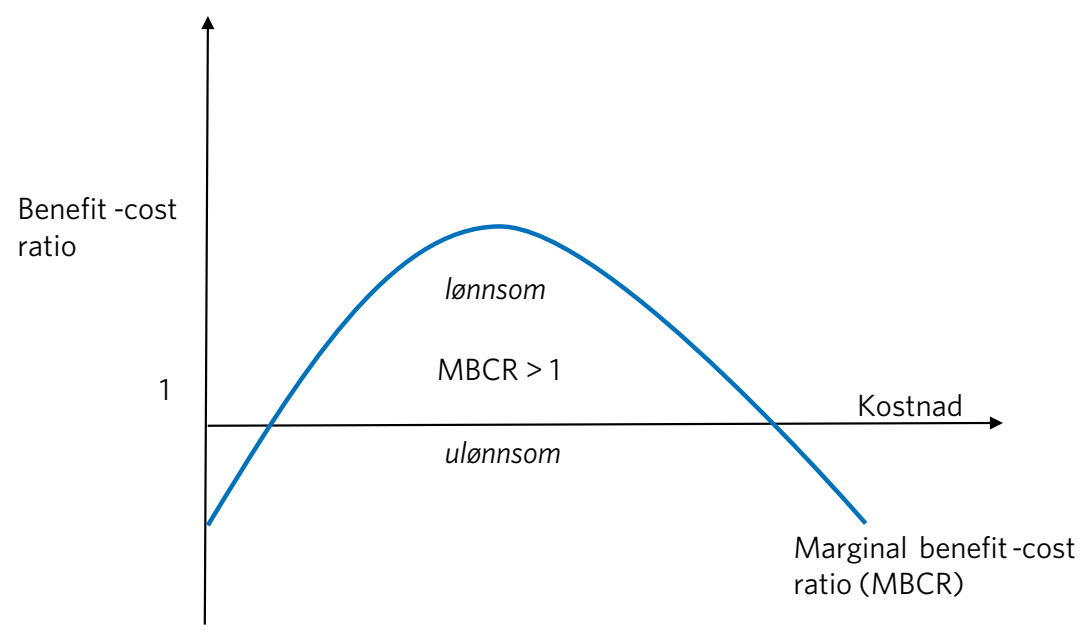

Figur 2 Vurderinger av generisk markedsføring: Sammenhengen mellom kostnadsnivå og benefit-cost ratio. MBCR=Marginal Benefit-Cost Ratio.

De økonometriske modellene gir relativt gode svar på det sentrale spørsmålet om hvorvidt den generiske markedsføringen er lønnsom. Det må 
likevel understrekes at slike analyser har sine begrensninger. Ikke minst er det en utfordring å isolere effekten av den generiske markedsføringen. Det er svært mange faktorer som påvirker omsetningen av kjøtt- og jordbruksprodukter. Selv om man forsøker å ta hensyn til alle kjente faktorer i modellene, vil det hefte usikkerhet ved estimatene.

Ifølge Crespi og Sexton (2013) var det i 2007 publisert mer enn 250 studier på effekter av generisk markedsføring av matprodukter. Den mest sentrale review-artikkelen for denne perioden er Alston, Crespi, Kaiser og Sexton (2007). Williams, Capps og Hanselka (2017) har siden gjennomgått 27 ytterligere studier, publisert i perioden 2007-2016. Konklusjonen i alle review-artiklene på feltet er entydig: Den generiske markedsføringen har i hovedsak vert meget lønnsom for produsentene (bøndene). Analyser av en lang rekke generiske markedsføringskampanjer i Australia viser lignende resultater.

Den ferskeste amerikanske analysen av 27 studier for perioden 20072016 (Williams et al., 2017) viser en gjennomsnittlig benefit-cost ratio (ABCR) på 9,69. Det betyr at man i gjennomsnitt fikk igjen mer enn ni ganger innsatsen i disse programmene. Variasjonen er imidlertid stor $(3,1$ til 15,55). Tar vi med resultatene fra tidligere perioder, finner vi også noen få eksempler på ulønnsomme kampanjer, men disse er unntak. Det er også interessant å notere at gjennomsnittlig marginal benefit-cost ratio (MBCR) for perioden 2007-2016 var 8,70. Dette betyr at den typiske kampanjen i tallmaterialet kunne oppnådd større effekter ved å utvide budsjettene og bruke mer penger på den generiske markedsføringen.

I tillegg til inntektseffekten for produsenter og detaljister, tyder forskningen på at den generiske markedsføringen gir betydelige ringvirkninger for andre næringer (Williams et al., 2017). Flere studier viser at effekten av generisk markedsføring ikke er lineær. I likhet med reklameforskning på andre områder, finner man at effekten av økte reklamekostnader er fallende ("the law of diminishing returns» - se Williams et al. 2017). Bildet er imidlertid mer nyansert enn dette. Når innsatsen på generisk markedsføring er liten, er den ofte ulønnsom. Den marginale benefit-cost-ratioen (MBCR) er da stigende ved økt pengebruk inntil et visst punkt hvor «the law of diminishing returns» slår inn. MBCR blir 
gradvis lavere inntil den faller under 1 igjen, og ytterligere pengebruk blir ulønnsom (se figur 2).

Dette bildet samsvarer også med reklameforskning på andre områder. Bruker man for lite penger på markedsføring, trenger man ikke gjennom støyen og når ikke ut til mange nok. Effekten uteblir. Kommer man over visse terskelverdier, blir kommunikasjonen sterk nok og effektene betraktelig bedre. Ut over dette vil en kunne høste stadig større effekter totalt sett, men effekten av den ekstra reklamekrona går gradvis ned.

Generisk markedsføring av nye kategorier synes å være særlig effektiv. Dette er ikke overraskende, siden markedet i slike tilfeller helt mangler kjennskap til produktene i utgangspunktet. Et godt eksempel er en amerikansk studie av generisk markedsføring av melkeproteiner (Balagtas \& Sumner, 2005). Gjennomsnittlig benefit-cost ratios (ABCR) for produsentene i denne studien lå $\mathrm{i}$ intervallet 40-79.

Flere studier viser at generisk markedsføring kan være meget effektivt for å redusere skadevirkningene av negativ publisitet. En generisk kampanje for å kontre negativ presseomtale for bringebær i California (19961997) var meget lønnsom, og reduserte inntektstapet anslagsvis med over 100 millioner USD (Richards \& Patterson, 2005). Et annet eksempel er en eksperimentell studie av effekten av kontrakommunikasjon mot negative presseoppslag om kugalskap (Messer, Kaiser, Payne \& Wansink, 2011). I kontrollgruppen falt betalingsviljen for hamburgerkjøtt med hele 58,9\% som følge av den negative informasjonen. I en gruppe hvor denne informasjonen ble kontret med positiv generisk kommunikasjon om hamburgerkjøtt, falt betalingsviljen bare med 3,3\%.

\section{Er det sannsynlig at Matprats generiske markedsføring er lønnsom?}

I perioden 2014-2018 har omsetningen økt for flere av varekategoriene Matprat har ansvar for, spesielt for svin og fjærkre. Det er imidlertid misvisende å kun fokusere på vekst når en skal vurdere effektene av Matprats virksomhet. Noen av matkategoriene har i perioden vært under negativt press i mediene, med dels sterk kritikk fra ulike perspektiver: dyrevern, miljø/klima og kosthold. Kritikken har særlig vært rettet mot rødt kjøtt, 
men også mot kjøttproduksjon generelt. Stabile omsetningstall for disse kategoriene er sannsynligvis uttrykk for betydelige positive effekter av den generiske markedsføringen, fordi man uten denne antagelig ville sett fall i omsetningen. Både den internasjonale forskningslitteraturen og markedsutviklingen for de aktuelle matvarekategoriene tyder altså på at Matprats aktiviteter kan være lønnsomme. Analyser av aktiviteten på Matprats hjemmesider, hvor forbrukerne henter oppskrifter og annen informasjon, drar i samme retning. Hjemmesiden har en sterk posisjon og aktiviteten er betydelig, med 36 millioner «økter» i 2017. Eksperimenter viser også at Matprats reklame oppfattes å være mer troverdig og overbevisende enn reklame for produktmerkene (Jakubanecs \& Skjeret, 2015). Matprat er i ferd med å utvikle økonometriske modeller som skal brukes i fremtidige analyser av effekter og lønnsomhet. I fravær av slike analyser, har vi gjort en enkel regneøvelse for å danne oss et grovt bilde av lønnsomheten.

Vi gjorde først et overslag på hva bonden satt igjen med basert på omsetningen i 2017. Vi hentet tall fra SSB, Landbruksdepartementet og NIBIO og gjorde et overslag på forbruket i markedet (i kilo) i de aktuelle matkategoriene i 2017. Deretter brukte vi de samme kildene til å lage grove overslag på hvilken pris bonden får, inklusive tilskudd, for en kilo av de samme produktene (overslag storfe: $50 \mathrm{kr} / \mathrm{kg}$, svin: $25 \mathrm{kr} / \mathrm{kg}$, lam: $40 \mathrm{kr} / \mathrm{kg}$, kylling: $20 \mathrm{kr} / \mathrm{kg}$, egg: $15 \mathrm{kr} / \mathrm{kg}$ ). Til sammen gav dette en samlet verdi til bonden på ca. 11,4 milliarder i 2017. Matprats budsjett på generisk markedsføring rettet mot forbruker lå på 40-46 millioner, antagelig 50-60 millioner dersom vi tar hensyn til lønnskostnader.

Dersom vi da antar at Matprats aktiviteter representerer en beskjeden effekt på $3 \%$ av omsetningen, tilsvarer dette en verdi på 342 millioner ( $3 \%$ av 11,4 milliarder), altså 5-6 ganger mer enn Matprats budsjett. Selv en marginal effekt på kun $1 \%$ svarer til 141 millioner - det dobbelte av budsjettet. Disse grove estimatene har sine begrensninger, men indikerer likevel at Matprats aktiviteter med høy sannsynlighet er lønnsomme. 


\section{Fører bruken av NytNorge-merket til at flere forbrukere velger norske produkter?}

NytNorge-merket ble introdusert i 2009 av Matmerk, en stiftelse etablert av Landbruks- og matdepartementet. NytNorge brukes som generisk merke på emballasjen og skal bidra til at flere forbrukere velger norske matprodukter oftere i butikken. For å benytte NytNorge-merket, må produktet bestå av norske råvarer, bonden må følge norske regler (KSL) og produktet må være pakket og produsert i Norge.

Ifølge årsrapporten for 2018 ble NytNorge-merket brukt på emballasjen til 3830 norske matprodukter i 2018. Det er et betydelig antall. Matmerk krever en avgift for denne eksponeringen, som delvis finansierer merkeordningen. I tillegg støttes ordningen via omsetningsavgiften og statsbudsjettet. Siden introduksjonen i 2009 er det investert godt over 100 millioner kroner i utvikling og markedsføring av merket.

\section{Problemer ved merkeordningen i lys av moderne reklame- og merkevareforskning}

NytNorge brukes ikke som hovedmerke, men som støttemerke underordnet produktmerket (f.eks. Gilde), plassert på et mer perifert sted på emballasjen enn produktmerket. For at eksponeringen av støttemerket skal ha noen effekt, må to hovedbetingelser oppfylles: Forbrukeren må legge merke til det i valgsituasjonen, og merket må representere informasjon som er relevant og komplementor i forhold til produktmerkets signaler. Det er fare for at NytNorge-merket kommer til kort med hensyn til begge disse betingelsene.

Forskning viser at forbrukernes oppmerksomhet først rettes mot emballasjens overordnede utseende/attraktivitet (gestalt) og deretter mot dominerende, kjente visuelle elementer (Palmer, 1999; Pieters \& Warlop, 1999). Innpakningen for de fleste kjøttprodukter domineres av kjente norske produktmerker som Nordfjordkjøtt, Finnsbråten, Gilde og Den Stolte Hane. Disse merkene er som regel plassert på det mest sentrale stedet, det vil si høyt oppe eller i midten, og med større font enn andre elementer på innpakningen. Når vi i tillegg observerer at det er mange 
andre visuelle elementer på pakningen enn NytNorge-merket, og legger til at beslutninger i butikk typisk skjer i løpet av få sekunder (Clement, Kristensen \& Grønhaug, 2013), skal det mye til for at NytNorge-merket fanger kundenes oppmerksomhet.

Dersom NytNorge-merket likevel legges merke til, er det grunn til å tro at merket sjelden bringer vesentlig ny og viktig informasjon. Det sentrale signalet merket sender ut handler om norsk opphav og identitet (navnet og flagget). Spørsmålet er om dette har noen tilleggseffekt ut over produktmerkenes signaler. Svært mange matvarekategorier domineres av kjente norske produktmerker. I disse kategoriene gir neppe NytNorgemerket vesentlig ny informasjon. Derfor vil vi forvente at NytNorgemerket gir ubetydelige tilleggseffekter. Vi utsatte denne antagelsen for en test i form av et simulert butikkeksperiment.

\section{Effekter av NytNorge-merket: En simulert butikktest}

Matmerks årsrapport for 2018 avsluttes med slagordet: «Får folk til å velge norsk». Stemmer dette for NytNorge-merket? Vi engasjerte Norstat til å gjennomføre et simulert butikkeksperiment. ${ }^{1} \mathrm{Vi}$ avgrenset studien til tre typer kjøttprodukter og eksponerte forbrukerne for valgsituasjoner hvor NytNorge-merket enten var med på emballasjen eller utelatt. Når NytNorge-merket var med på emballasjen, var eksponeringen identisk med den reelle eksponeringen på emballasjen i butikken (samme font og plassering). Deltagerne var helt eller delvis ansvarlige for innkjøp av mat til husstanden og alle hadde et kosthold som inkluderte kjøttprodukter.

Tre hundre deltagere ble bedt om å forestille seg at de var i butikken og at de skulle kjøpe tre typer produkter: entrecote, bacon og salami. I hver kategori fikk de velge mellom fire alternativer: tre norske og ett utenlandsk produkt. Ett av de norske produktmerkene i hver kategori var private label (handelens egne merkevarer). Følgende produktmerker var med i studien: bacon: Gilde, Finsbråten, First Price og Tulip; salami: Gilde, Frilstad, First Price og Tulip; entrecote: Gilde, Nordfjord, Folkets

1 Eksperimentet ble finansiert av Opplysningskontoret for egg og kjøtt. Opplysningskontoret hadde ingen innflytelse på valg av design eller gjennomføring av studien. 
og Pampas. Gjeldende priser ble vist på en prislapp under emballasjen. Hvilket norsk produkt som hadde NytNorge-merket ble systematisk variert og deltagerne ble tilfeldig fordelt på de ulike eksponeringsvariantene. På denne måten kunne vi for hvert norsk produktmerke i alle de tre kategoriene (til sammen 9 produktmerker) teste effekten av å bruke NytNorge-merket.

Resultatene var entydige: NytNorgemerket hadde ikke en eneste signifikant effekt på valg av produkt $(\mathrm{p}<, 05)$ for noen av de ni norske produktmerkene i testen. Selv da vi testet effekten på de mest etnosentriske forbrukerne (som særlig foretrekker nasjonale merker), fant vi ingen effekter. På spørsmål i etterkant av testen om hvilken informasjon på innpakningen deltagerne
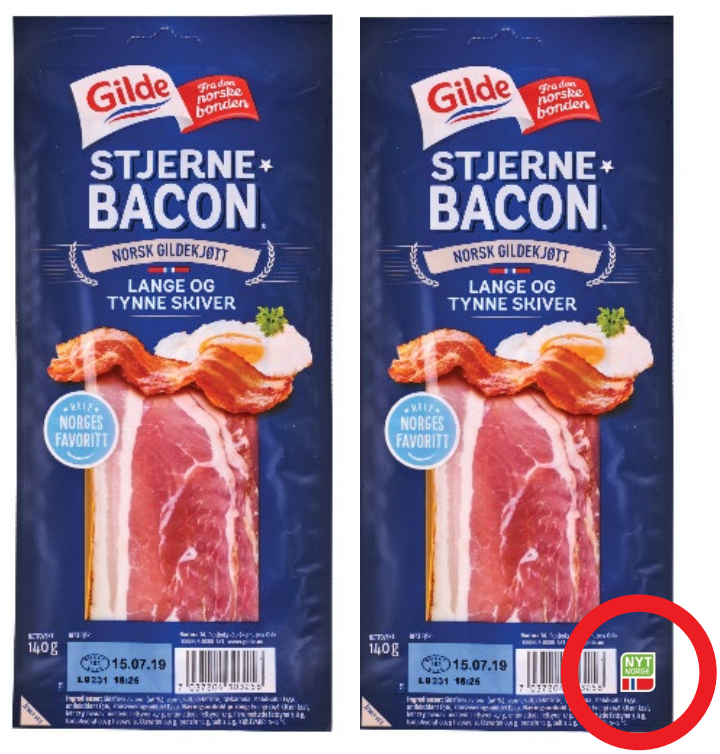

Bilde 2. Eksempler på stimuli i eksperimentet: Emballasje med og uten NytNorge-merket. (Foto: BRAND COGNITION AS, gjengitt med tillatelse). la vekt på da de valgte produkter (uhjulpet test, det vil si uten alternativer), var responsen dominert av produktmerket («godt merke», «kjent merke»), emballasjens attraktivitet («så godt ut») og pris (for lavprisvariantene). Dette er konsistent med tidligere forskning på hvilke emballasjeelementer som tiltrekker seg forbrukernes oppmerksomhet. At produktet var «norsk» ble nevnt av en del (typisk 10-15\%), men ikke av signifikant flere når NytNorge-merket var med på emballasjen enn når den var utelatt. Selve NytNorge-merket ble nevnt av svært få. For kun for 2 av 9 merker var det noen som nevnte NytNorge i det hele tatt. Den høyeste responsen var på beskjedne 3,8 \% (for Gilde entrecote).

Testen ble gjennomført på tre produktkategorier. Det er ikke utenkelig at NytNorge-merket kan ha en viss effekt for svake/ukjente produktmerker i andre kategorier, hvor konkurransen fra utenlandske alternativer er større. Svært mange matkategorier i norsk dagligvarehandel er imidlertid dominert av sterke norske produktmerker. Våre resultater tyder på at effekten av NytNorge-merket vil være minimal i disse kategoriene. 
Våre resultater harmonerer dårlig med Matmerks egne påstander om ordningens effektivitet. Hvilken dokumentasjon legger Matmerk til grunn for sine påstander? På Matmerks hjemmesider finner vi tre typer dokumentasjon (se f.eks. https://www.matmerk.no/no/matmerk/aktuelt/ flere-velger-norsk-mat-naar-de-kan). For det første refereres det til tall på merkekjennskap. Det rapporteres at kjennskapen til NytNorge-merket er høy og stabil, 88 \% i 2017 og 89 \% i 2018. Slike kjennskapstall er imidlertid uegnet til å si noe om effekten av merket i reelle valgsituasjoner i butikken. Høy kjennskap er en betingelse for at merket skal ha en effekt, men ikke en tilstrekkelig betingelse. Dessuten er det uklart hva kjennskapstallene egentlig representerer. Forbrukerne har svart på følgende spørsmål: «Hvilke informasjons- og kvalitetsmerker for mat kjenner du til?». Så har deltagerne fått se visuelle presentasjoner av logoene og krysset av for logoer de kjente igjen (såkalt hjulpen kjennskap). Dette er en meget svak kjennskapstest og overrapportering er et velkjent problem i slike tester (Aribarg, Pieters \& Wedel, 2010). Det er også uklart hva responsen egentlig betyr. Halvparten av NytNorge-merket består av det norske flagget (eller deler av dette). Alle kjenner det norske flagget. Hvor høye tall hadde man fått om man bare brukte det norske flagget $\mathrm{i}$ testen?

For det andre oppgir Matmerk andelen som sier at de ser aktivt etter NytNorge-merket i en kjøpssituasjon. Denne indirekte måten å måle effekt på har også en rekke metodiske svakheter. Det kan forventes betydelig overrapportering. Det er velkjent at deltagere i undersøkelser gjetter på hva som er «ønskelige responser» og tilpasser seg dette (Bearden, Netemeyer \& Haws 2011). Det er åpenbart ønskelig i vår sammenheng at man «ser aktivt etter NytNorge-merket». Dette fører til overrapportering. For det andre er det også her uklart hva deltagerne egentlig svarer på. Når de bekrefter at de «ser etter NytNorge-merket» som eksponeres visuelt med et norsk flagg i testen, mener de da at de sjekker om produktet er norsk, eller at de ser etter dette spesifikke merket på emballasjen? Det er sannsynlig at begge tankeprosesser gjør seg gjeldende. Dette vil også føre til overrapportering. For det tredje har forbrukere en generell tendens til å rasjonalisere egne valg i etterkant for å fremstå rasjonelle i egne og andres øyne. Dette vil kunne lede noen til å bekrefte at de ser etter 
NytNorge-merket i butikken, uten at så er tilfelle i virkeligheten. Også denne mekanismen medfører overrapportering.

Matmerk rapporterer for det tredje andelen forbrukere som bekrefter/ avkrefter følgende påstand: «NytNorge gjør at jeg får lyst til å kjøpe norsk mat». Igjen benyttes spørsmål som ber om aktiv bekreftelse på ønskelig atferd. De samme innvendingene vi hadde til forrige spørsmål gjelder også her.

Det er særlig to typer metodikk som er egnet til å teste årsakvirkningssammenhenger, som effekten av NytNorge-merket på valg av matvareprodukt: Eksperimenter og økonometriske analyser av tidsseriedata (Wiedermann \& von Eye, 2016). Dette er velkjent i faglitteraturen. I stedet for slike tester har Matmerk i flere år rapportert resultater fra uegnede undersøkelser som med stor sannsynlighet overrapporterer merkets betydning. Mangelen på effekter i vårt eksperiment styrker denne mistanken.

\section{Konklusjoner}

Mange forbrukere setter pris på at matvarene de finner i butikkene har norsk opprinnelse. Opphavsassosiasjoner (OA) kan påvirke både merkepreferansen og betalingsvilligheten. Skal man hente ut dette potensialet, er det ikke tilstrekkelig å bruke et norsk produktnavn eller henge på et generisk merke med norkk flagg, som NytNorge. Merkevareforskningen har vist oss at OA kan påvirke merkepreferanser på mange ulike måter. OA må knyttes til nytteassosiasjonene i produktmerkets posisjonering med utgangspunkt i de spesielle særtrekkene ved den enkelte merkevare. Dette krever innsikt i etablerte merkeassosiasjoner, forbrukernes beslutningsprosesser og effektene av aktuelle OA (Norge, Trøndelag, Lofoten, etc.). I dette kapittelet har vi gjort rede for hvordan man kan utforske dette potensialet for å styrke merkevarens identitet med opphavsassosiasjoner.

For det andre stilte vi spørsmålet om NytNorge-merket og Matprat bidrar effektivt til å gjøre norske produkter mer attraktive og derved stimulerer etterspørselen. Matprats virksomhet er sammensatt og vanskelig å vurdere uten gode økonometriske analyser. Det er likevel sannsynlig at Matprats aktiviteter bidrar positivt til å gjøre kategorien «norsk kjøtt»og 
underkategoriene «norsk kylling», «norsk svinekjøtt» osv. mer attraktive, og derved stimulerer etterspørselen i tilstrekkelig grad til at virksomheten er lønnsom. Grove beregninger viser at selv ved beskjedne effekter av den generiske markedsføringen på bare $1 \%$ av omsetningen, er lønnsomheten god.

Satsingen på merkeordningen NytNorge bør på den annen side revurderes. I tråd med vurderinger av ordningen basert på innsikter fra internasjonal emballasje- og merkevareforskning, fant vi ingen effekter av NytNorge-merket $i$ et simulert butikkeksperiment, ikke en gang $i$ undergrupper som er særlig opptatte av opphav. Matmerks egen dokumentasjon av effekter er utilstrekkelig og dels misvisende. Det bør snarlig gjennomføres nye eksperimenter som tester de reelle effektene av NytNorge-merket i flere varekategorier. Det bør også gjennomføres slike tester for de andre generiske merkene Matmerk forvalter (Spesialitet og Beskyttede Betegnelser). Eksperimentene vil danne grunnlag for grove lønnsomhetsvurderinger. Dersom det ikke kan vises til betydelige effekter, bør virksomheten saneres eller legges om, med fokus på utvalgte kategorier og produktmerker som får beviselig drahjelp av NytNorge-merket.

Det er grunn til å tro at Matmerk ikke er alene i bransjen om å benytte uegnede metoder for å dokumentere effekter. Det positive er at det finnes gode løsninger på dette problemet. Dagens omfattende digitalisering av data samt nye økonometriske og eksperimentelle metoder muliggjør analyser som er langt mer presise og etterrettelige enn enkle korrelasjoner og sammenligninger av gjennomsnitt (på ledende spørsmål). Presis informasjon om effekter er nødvendig for å vurdere den reelle lønnsomheten, men også for å utvikle kunnskap om hvilke virkemidler eller aktiviteter som gir best effekt. 


\section{Referanser}

Alston, J.M., Crespi, J.M., Kaiser, H.M. \& Sexton, R.J. (2007). An evaluation of California's mandated commodity promotion programs. Review of Agricultural Economics, 29(1), 40-63. https://doi.org/10.1111/j.1467-9353.2006.00329.x

Aribarg, A., Pieters, R. \& Wedel, M. (2010). Raising the BAR: Bias adjustment of recognition tests in advertising. Journal of Marketing Research, 47(3), 387-400. https://doi.org/10.1509/jmkr.47.3.387

Balagtas, J. V. \& Sumner, D. A. (2005). Returns to the dairy check-off investment in research for new uses of whey. I H. M. Kaiser, J. M. Alston, J. M. Crespi, \& R. J. Sexton (Red.), The economics of commodity promotion programs: Lessons from California (s. 315-338). New York: Peter Lang Publishing.

Botti, S. \& McGill, A. L. (2011). The locus of choice: Personal causality and satisfaction with hedonic and utilitarian decisions. Journal of Consumer Research, 37(6), 1065-1078. https://doi.org/10.1086/656570

Clement, J., Kristensen, T. \& Grønhaug, K. (2013). Understanding consumers' in-store visual perception: The influence of package design features on visual attention. Journal Retailing and Consumer Services, 20(2), 234-239. https://doi.org/10.1016/j.jretconser.2013.01.003

Crespi, J. M. \& Sexton, R. J. (2013). US generic advertising and promotion programs. I W. J. Armbruster \& R. D. Knutson (Red.), US programs affecting food and agricultural marketing (s. 171-194). Springer: New York.

Han, C. M. (1989). Country image: Halo or summary construct? Journal of Marketing Research, 26(2), 222-229. https://doi.org/10.1177/002224378902600208

Hong, S. \& Wyer, R. S. (1989). Effects of country-of-origin and product-attribute information on product evaluation: An information processing perspective, Journal of Consumer Research, 16(2), 175-187. https://doi.org/10.1086/209206

Jakubanecs, A. \& Skjeret, F. (2015). Effekter av generisk markedsføring av Matprat. Rapport, prosjekt 0153/o154. Bergen: Stiftelsen Næringsforskning

Kaiser, H. (2015). Econometric analysis of Norwegian seafood council salmon export promotion to the European Union. Unpublished report. Ithaca: Cornell University.

Keller, K. L. (2012). Strategic brand management (4. utg.). Upper Saddle River, NJ: Prentice-Hall.

Koschate, N., Diamantopoulos, A. \& Oldenkotte, K. (2012). Are consumers really willing to pay more for a favorable country image? A Study of country-of-origin effects on willingness to pay. Journal of International Marketing, 20 (1), 19-41. https://doi.org/10.1509/jim.10.0140 
Li, W-K. \& Wyer jr., R. S. (1994). The role of country of origin in product evaluations: Informational and standard-of-comparison effects. Journal of Consumer Psychology, 3(2), 187-212. https://doi.org/10.1016/S1057-7408(08)80004-6

Messer, K. D., Kaiser, H. M., Payne, C. \& Wansink, B. (2011). Can generic advertising alleviate consumer concerns over food scares? Applied Economics, 43(12), 1535-1549. https://doi.org/10.1080/00036840802600616

Mizik, N. \& Jacobson, R. (2008). The financial value impact of perceptual brand attributes. Journal of Marketing Research, 45(1), 15-32. https://doi.org/10.1509/ jmkr.45.1.015

Mizik, N. \& Jacobson, R. (2009). Valuing branded businesses. Journal of Marketing, 73(6), 137-153. https://doi.org/10.1509/jmkg.73.6.137

Myrland, Ø., Emaus, P-A., Roheim, C. \& Kinnucan, H. W. (2004). Promotion and consumer choices: Analysis of advertising effects on the Japanese market for Norwegian Salmon.Aquaculture Economics \& Management, 8(1-2), 1-18. https://doi.org/10.1080/13657300409380350

Park, C. W., Jaworski, B. J. \& Maclnnis, D. J. (1986). Strategic brand concept-image management. Journal of Marketing, 50(4), 135-145. https://doi.org/10.1177/002224298605000401

Pieters, R. \& Warlop, L. (1999). Visual attention during brand choice: The impact of time pressure and task motivation. International Journal of Research in Marketing, 16(1), 1-16. https://doi.org/10.1016/So167-8116(98)ooo22-6

Pieters, R. \& Wedel, M. (2004). Attention capture and transfer in advertising: Brand, pictorial, and text-size effects. Journal of Marketing, 68(2), 36-50. https://doi.org/10.1509/jmkg.68.2.36.27794

Rego, L. L., Billett, M. T. \& Morgan, N.A. (2009). Consumer-based brand equity and firm risk. Journal of Marketing, 73(6), 47-6o. https://doi.org/10.1509/jmkg.73.6.47

Richards, T. J. \& Patterson P. M. (2005). The economic value of spin control: Food safety and the strawberry case. I H. M. Kaiser, J. M. Alston, J. M. Crespi, \& R. J. Sexton (Red.), The economics of commodity promotion programs: Lessons from California (s. 315-338). New York: Peter Lang Publishing.

Supphellen, M. (2014). Merkeposisjonering. I M. Supphellen, H. Thorbjørnsen \& S. V. Troye (Red.), Markedsføring: Verdibasert forventningsledelse. Bergen: Fagbokforlaget.

Wiedermann, W. \& von Eye, A. (Red.) (2016). Statistics and causality: Methods for applied empirical research. New York: Wiley.

Williams, G. W., Capps jr., O. \& Hanselka, D. (2018). U.S. national economic contribution of generic food and agricultural product advertising. Journal of International Food \& Agribusiness Marketing, 3o(2), 191-210. https://doi.org/10.1080/o8974438.2017.1402729 


\title{
KAPITTEL 7
}

\section{Det store forhandlingsspillet: vinnere, tapere og reguleringsbehovet}

\section{Erling Hjelmeng}

Universitetet i Oslo/Norges Handelshøyskole ${ }^{1}$

\begin{abstract}
This chapter takes the negotiations between suppliers and grocery chains as a starting point and discusses its impact on competition at the retail level. The aim is to analyse the potential for regulatory intervention, both with regard to unfair practices as well as competition, and also to discuss the application of the prohibition on abuse of dominant position in the grocery market. Several aspects are discussed; price discrimination, access to distribution and the use of vertical restraints. The main insight is that as no consistent theory of harm has yet been defined, it is not possible to give recommendations as to regulatory intervention.
\end{abstract}

Keywords: price discrimination, unfair trade practices, abuse of dominance

1 Forfatteren ledet Dagligvarelovutvalget som fremla NOU 2013:6 God handelsskikk i dagligvarekjeden, og har senere bistått Nærings- og fiskeridepartementet med oppfølgningen av lovforslaget. Videre har han arbeidet for NorgesGruppen, Dagligvareleverandørenes forening (DLF) og Virke i forbindelse med forslag om å innføre et forbud mot prisdiskriminering.

Sitering av denne artikkelen: Hjelmeng, E. (2020). Det store forhandlingsspillet: vinnere, tapere og reguleringsbehovet. I F. Steen \& I. Pettersen (Red.), Mot bedre vitende i norsk matsektor (Kap. 7, s. 215-266). Oslo: Cappelen Damm Akademisk. https://doi.org/10.23865/noasp.93.ch7 Lisens: CC BY-ND 4.o. 


\section{Innledning}

I dette kapittelet utforskes forhandlingene innenfor dagligvaresektoren nærmere, og da fra et reguleringsperspektiv. Fra Steensnæsutvalgets rapport Mat, makt og avmakt i 2011, via Dagligvarelovutvalgets forslag om lov om god handelsskikk (2013) og Stortingets vedtak om lov om god handelsskikk og utredning av konkurransefremmende tiltak av 28. mai 2018, til proposisjonen om lov om god handelsskikk av 6. desember 2019, har det vært fremmet en rekke forslag til ulike reguleringer i bransjen. ${ }^{2}$ Forslagene har vært motivert ut fra to ulike forhold; påstander om uredelige/uetiske metoder i forhandlinger, og påstander om konkurransepolitiske utfordringer, særlig knyttet til prisdiskriminering og etableringsbarrierer. ${ }^{3}$

Det er særlig følgende fem idéer og forslag som settes under lupen, hvorav det første gjelder effektivitet i kontraktsforhandlinger, mens de fire siste har en konkurransepolitisk begrunnelse:

- Lov om god handelsskikk,

- forbud mot prisdiskriminering,

- åpen tilgang til grossist/distribusjonsfunksjon,

- ekstra begrensninger på vertikalt samarbeid og

- maksimalgrenser for markedsandeler.

Disse fem forslagene til økt effektivitet og konkurranse gjennomgås med vekt på forhold til eksisterende rett og mulige effekter for effektivitet og konkurranse. Tilnærmingen er juridisk, men fremstillingen trekker også veksler på økonomisk teori.

2 Hhv. NOU 2011:4, NOU 2013:6, Innst. 292 S (2017-2018) og Prop. 33 L (2019-2020) Lov om god handelsskikk i dagligvarekjeden (til den siste se også Høringsnotat: Forslag til lov om god handelsskikk i dagligvarekjeden, 26.4.19, https://www.regjeringen.no/no/dokumenter/horing-omforslag-til-lov-om-god-handelsskikk-i-dagligvarekjeden/id2641752/).

3 De konkurransepolitiske innspillene har særlig sammenheng med Oslo Economics' rapport «Etableringshindringer i dagligvaresektoren», utredning på oppdrag for Nærings- og fiskeridepartementet, 2017 (https://osloeconomics.no/wp-content/uploads/Etableringshindringeri-dagligvaresektoren_ref2.pdf). Dette er også bakgrunnen for Stortingets vedtak om å be om en utredning av bl.a. forbud mot prisdiskriminering overfor dominerende leverandører (Dokument 8:170 S (2017-2018), Innst. 292 S (2017-2018). 
For å kunne drøfte både reguleringsbehov og reguleringsmuligheter under de alternativene som er skissert ovenfor, er det nødvendig først å gi en beskrivelse av egenarten i forhandlingene mellom leverandører og kjeder i det norske markedet.

\section{Forhandlingsspillet og konkurransepolitiske problemstillinger}

Forhandlingene mellom leverandører og kjeder i det norske markedet omtales gjerne som «høstjakta», og har et skjær av mystikk over seg. ${ }^{4}$ Det som er klart, er at kjedenes innkjøp av varer omfatter mye mer enn dette, ikke minst innenfor non-food. Det er heller ikke grunn til å tro at alle leverandørkontrakter gjenåpnes fullt ut hvert år, men det er lite tilgjengelig offentlig informasjon om dette. Fokuset i debatten rundt forhandlingsspillet i norsk dagligvare har imidlertid vært sentrert rundt «høstjakta», og som det er dokumentert gjennom Steensnæs-utvalgets arbeid har det fra leverandørhold vært utstrakt misnøye både mht. regi og gjennomføring av forhandlingene.5 Dagligvarelovutvalget (NOU 2013:6) tok ikke stilling til de mange historiene som ble formidlet til Steensnæs, men antok at uroen i bransjen indikerte at den hadde kjørt seg inn i et spor som i alle fall ikke fremmet effektivitet i forhandlingene. Dette utvalget fant det også vanskelig å skille mellom klagemål som skyldtes misnøye med forhandlingsresultatet og genuin frykt og uakseptable forretningsmetoder. Forslaget til lov om god handelsskikk og hvordan dette tar sikte på å løse disse (mulige) problemstillingene tas opp nedenfor.

Det er uansett ingen grunn til å betvile at forhandlinger er viktige. For det første vil forhandlinger normalt bidra til effektive kontraktsløsninger og dermed verdiskapning, som forhandlingspartene har en felles interesse i (mer om dette nedenfor). For det andre opptrer dagligvarekjedene som agenter for forbrukerne, noe som dels er viktig for at forbrukerpreferanser skal kommuniseres tydelig tilbake til leverandørene

\footnotetext{
4 Faktumbeskrivelsen som presenteres her bygger på samtaler med kjeder, leverandører og organisasjoner. Det er ikke foretatt noen vitenskapelig empirisk spørreundersøkelse. 
(noe som også inkluderer å velge bort produkter), dels for å oppnå lave priser som kan føres videre til forbrukerne. Det siste betinger imidlertid at konkurransen mellom kjedene fungerer, slik at verdiskapningen ikke avleires i kjedeleddet. Dette poenget bringer oss videre til spørsmålet om sammenhengen mellom konkurransen på kjedeleddet og måten prisene fremforhandles på.

I alle markeder kan det være kilder til konkurransemessige utfordringer, her definert slik at konkurransen ikke fungerer optimalt. Slike utfordringer kan skyldes strukturelle forhold i markedet, at det er faktiske eller regulatoriske etableringsbarrierer, eller at ett eller flere foretak agerer på en konkurransebegrensende måte. Sistnevnte kan enten være å hindre at andre får tilgang til markedet, eller at konkurransen mellom aktørene på markedet begrenses.

Konkurransepolitisk er det særlig to spørsmål som kan knyttes til forhandlingsspillet: Hvordan er forholdet mellom forhandlingssystemet og den asymmetrien i priser mellom ulike kjeder som Konkurransetilsynet har avdekket? ${ }^{6}$ Vil forhandlingssystemet også på andre måter kunne ha betydning for konkurransen mellom kjedene? Spørsmålet om asymmetri kan relateres både til en mulig konkurranseulempe for andre etablerte kjeder, eller som en etableringsbarriere for nykommere.

Sentralt for forhandlingsspillet er modellen det forhandles etter. Modellen her varierer mellom kjedene, men samtlige prismodeller tar utgangspunkt i G-pris (leverandørens listepris). Denne er så langt jeg kjenner til identisk overfor alle kjedene. Fellestrekket er at prisforhandlingene mellom kjeder og leverandører hovedsakelig dreier seg om rabatter på G-pris. Enkelte kjeder (NorgesGruppen) har historisk likevel ikke forhandlet direkte på G-pris, men på en intern avregningsfaktor som kalles D-pris (detaljistpris). Dette innebærer at det har blitt forhandlet rabatter i \% av en pris som settes av NorgesGruppen, mens kronebeløpet trekkes fra i G-pris.? Avhengig av utviklingen i forholdet mellom G- og D-pris, vil dette kunne føre til skjevheter mellom kunder over tid samt ved pris- eller avgiftsøkninger som legges på G-pris, jf. nedenfor. Generelt

6 Tilsynets rapport av 13. november 2019 er tilgjengelig på https://konkurransetilsynet.no/wpcontent/uploads/2019/11/Rapport-om-innkjøpsbetingelser_2019.pdf.

7 Systemet er beskrevet i NOU 2013:6, s. 61-62. 
gjelder at ulike størrelse på de samlede rabattene vil gi kjedene ulike vilkår (netto salgsverdi eller NSV). ${ }^{8}$

Forhandlingsformen med utgangspunkt i G-pris og rabatter har noen implikasjoner som er svært relevante for en konkurransepolitisk og konkurranserettslig forståelse av det norske markedet. Leverandørene har naturlig nok et incitament til å tilby en høy G-pris, siden dette flytter utgangspunktet for forhandlingene. Dermed vil man også være villig til å strekke seg lenger mht. rabattytelser i forhandlingene. Det er dette som omtales som «luft» i kalkylene, siden G-prisen representerer et utgangspunkt for forhandlingene (som settes likt overfor ulike kunder).

Rabattene som gis, allokeres til ulike nivåer i kjedene; noen gis til butikk, andre til sentralledd og andre til distribusjonsleddet. De langt fleste forhandles av kjedenes sentralledd, men det er også eksempler på at rabatter i form av felles markedsføring (joint marketing, JM) forhandles av profilhuset, f.eks. KIWI eller Meny. ${ }^{9}$ Så vidt jeg vet regnes de langt fleste rabatter i prosent av G-pris (ev. D-pris), eller som faste kronebeløp. ${ }^{10}$ Dette fører til effekter som at rabatt til enkeltledd i verdikjeden, dvs. betaling til disse leddene, blir høyere jo høyere G-prisen settes. Dette kan redusere kjedenes incentiver til å protestere på økninger i prisgrunnlaget, siden fokuset i forhandlingene uansett ligger på rabattene.

Effektene av en felles bruk av forhandlingsmodell kan ha betydning for pris til sluttkunde. En inflatert G-pris vil kunne virke som et fokalpunkt som skaper en felles forståelse mellom kjedene om at deler av denne består i rabatter som allokeres til f.eks. sentralledd og ikke tas ut i konkurranse

8 En reell prissammenligning mellom kjeder må nødvendigvis ta utgangspunkt i prisene etter at rabatter, samarbeidsbonuser etc. er fratrukket (med unntak selvsagt for fradrag som representerer genuine motytelser). Konkurransetilsynet foretar sin kartlegging på tre størrelser: «netto innkjøpspris», «variabel innkjøpspris» og «motytelsesjustert innkjøpspris», se rapporten pkt. 2.2.1.

9 Også Bunnpris, som har et innkjøpssamarbeid med NorgesGruppen, forhandler JM separat.

10 Fordelingen mellom prosentvise rabatter og faste beløp er usikker. Det har tidligere vært antatt at kontraktene er ikke-lineære, og derfor effektive, se for eksempel Gabrielsen (2013) s. 106-109 (hylleplassbetaling og JM), med henvisning til Matkjedeutvalget (NOU 2011:4). Jf. videre NOU 2013:6, s. 51 ff. Sannsynligvis forekommer begge former for kontrakter i det norske markedet, men det er ikke mulig å si noe om fordelingen mellom dem. 
nedstrøms. ${ }^{11}$ Skal dette være tilfelle må det foreligge en eller annen form for koordinert likevekt mellom kjedene. (Koordinert likevekt benyttes her i økonomisk forstand, dvs. at det ikke ligger noen implikasjoner om kontakt mellom kjedene, noe som i tilfelle ville vært i strid med konkurranseloven.) En slik forhandlingsstruktur kan således i prinsippet føre til $ø$ kte sluttbrukerpriser og en avleiring av profitt i den kjedekontrollerte delen av verdikjeden, forutsatt at strukturen påvirker konkurransen mellom kjedene.

Samtidig har modellen noen egenskaper som både vil kunne bidra til å forsterke eventuelle prisforskjeller mellom kjedene ved prisjusteringer fra leverandør $i$ «prisvinduene». Ved en avgiftsøkning (der avgiften er del av forhandlingsgrunnlaget) vil f.eks. en økning av G-pris reelt sett øke distribusjonsleddets inntekter (siden «rabatten» eller distribusjonsvederlaget regnes i prosent av denne prisen). ${ }^{12}$ For å oppnå en inndekning av avgiftsøkningen (i vederlaget kjedene reelt sett betaler (netto salgsverdi)), vil leverandør således måtte øke G-pris utover den nominelle avgiftsøkningen (siden mye «forsvinner» i rabatter). Dette kan slå ulikt ut overfor ulike kunder, avhengig av hvilke rabatter og rabattstruktur som er fremforhandlet. Paradoksalt nok kan derfor en kunde som har oppnådd best betingelser (rabatter) i forhandlingene, ende opp med å bære en mindre andel av avgiftsøkningen enn konkurrentene.

Selv om forhandlingene foregår på prosentvise rabatter av G- eller D-pris, gir ikke dette i seg selv en kjede en fordel overfor andre - siden alle står fritt til å forhandle på disse parametrene. Riktignok ble det under behandlingen av lov om god handelsskikk hevdet at D-prismodellen til NorgesGruppen ga slike fordeler. Forutsetningen må da være at NorgesGruppen ensidig kan endre D-pris, eller som nevnt ovenfor at forskjellen mellom G- og D-pris øker skjevheter ved pris- eller avgiftsendringer. Forskjellen mellom G- og D-prismodell kan imidlertid ikke i seg selv

11 Dagligvarelovutvalget drøftet dette spesifikt bare for D-prismodellen, og kom til at denne modellen neppe i seg selv ville ha prisdrivende virkninger dersom den bare ble anvendt av én leverandør. Utvalget påpekte likevel at en felles prismodell som ble benyttet av samtlige kjeder ville kunne ha slik virkning. (s. 62).

12 Så vidt jeg har forstått, inngår visse avgifter, f.eks. sukkeravgift, i forhandlingsgrunnlaget. Nettopp sukkeravgiften er ellers et interessant eksempel, da denne ble økt i 2018 ga det umiddelbart utslag på forbrukerpriser, mens reduksjonen i 2019 ikke ga tilsvarende utslag. 
forklare betydelige prisforskjeller, så dersom NorgesGruppen oppnår bedre betingelser enn andre kjeder innenfor de rammene for forhandlinger som er skissert, er bedre forhandlingsteknikk/forhandingsmakt også sannsynligvis et betydelig bidrag. Det er likevel vanskelig å utelukke at innenfor en struktur der alle kjedene benytter en prismodell som virker prisdrivende på denne måten, vil $\mathrm{D}$-prismodellen kunne representere en forsterket effekt for NorgesGruppen (i den forstand at modellene samlet virker prisdrivende overfor sluttkunde og at NorgesGruppen samtidig sitter igjen med mer enn øvrige kjeder). ${ }^{13}$

Spørsmålet er hvordan en slik forhandlingsstruktur kan opprettholdes i et marked med presumtivt sterke leverandører og konkurranse mellom kjedene. Her skal det bare angis et par utgangspunkter.

For det første er det grunn til å sette spørsmålstegn ved leverandørmakten i det norske markedet, spesielt dersom det ses på leverandører med en variert produktportefølje. En dominerende leverandør kan utnytte markedsmakt i et marked man er dominerende i til å øke markedsandel i et annet marked. Tilsvarende vil en kjøper med kjøpermakt kunne utnytte denne i et marked leverandøren er svak i til å skaffe kontroll over et marked hvor leverandøren er sterk (en slags omvendt leveraging). Dette er ikke i seg selv et problem, men mer et eksempel på at motstående kjøpermakt («countervailing buyer power») kan anta ulike former, som ikke nødvendigvis kan henføres til markeder for enkeltprodukter. Dette representerer en tentativ forklaring for hvorfor leverandørsiden ikke kan kvitte seg med den forhandlingsstrukturen som er rådende på markedet, jf. nedenfor om dominans vs. kjøpermakt.

For det andre er spørsmålet hvorfor ikke konkurransen mellom kjedene avhjelper de mulige prisdrivende effektene som er forklart ovenfor. I denne sammenheng er det viktig å understreke at det norske dagligvaremarkedet er svært gjennomsiktig, jf. ordningen med prisjegere og tidligere Konkurransetilsynets påpekning av skadevirkningene av systemet med informasjonsutveksling via AC Nielsen. Det kan altså

13 Dagligvarelovutvalget vurderte D-prismodellen isolert, og ikke den samlede effekten av G- og D-prismodell. Lovutvalget aksepterte, jf. rett ovenfor, at kollektiv bruk av en prismodell kunne virke prisdrivende. Det bør understrekes at utvalgets forutsetning var velfungerende konkurranse mellom kjedene. 
foreligge koordinerte virkninger mellom kjedene, men det må understrekes at dette vil være et strukturelt problem i markedet, og ikke vil representere et brudd på konkurranseloven.

At en felles prismodell anvendt av kjedene vil kunne fungere som en koordineringsmekanisme ble påpekt av Dagligvarelovutvalget. ${ }^{14}$ Utvalget drøfter dette i sammenheng med vurderingen av NorgesGruppens D-prismodell. Her heter det:

Dersom det hadde vært slik at samtlige kjeder brukte en tilsvarende modell, kan det tenkes at kjedene kollektivt sett kunne ha kommet bedre ut ved at modellen virker som en koordineringsmekanisme i markedet. En slik koordinering vil antakeligvis måtte basere seg på enten stilltiende eller eksplisitt enighet om å bruke denne eller tilsvarende prisingsmodeller, og vil være utsatt for de samme stabilitetsbetraktningene som omgir vanlig koordinering. Utvalget understreker at det er en premiss for diskusjonen at konkurransen mellom kjedene fungerer. Dersom kjedene samlet benytter prismodeller som koordineringsmekanisme, bør dette adresseres etter konkurranseloven, sannsynligvis som et spørsmål om misbruk av kollektiv dominans.... ${ }^{15}$

Det påpekes her at forhandlingsmodellen kan fungere som en «koordineringsmekanisme i markedet» og da basert på en stilltiende enighet om å benytte modellen. Dersom prismodellen også har en prisdrivende effekt, innebærer dette en risiko for at sluttbrukerprisen økes. Poenget er at alle har kjennskap til den felles (kunstig høye) G-prisen, og at det fra denne trekkes ulike rabatter/vederlag som allokeres til ulike punkter i verdikjeden (for eksempel distribusjonsvederlag). Dette vil muligens kunne gi opphav til en felles forståelse om at ikke alle rabatter skal tas ut i konkurranse på pris overfor forbruker. Det kan også reises spørsmål om hvordan modellen påvirker incentivene til å effektivisere for eksempel distribusjonsleddet.

I en situasjon med slike asymmetriske priser som er påvist av Konkurransetilsynet, skulle en forvente at forskjellene ville bli tatt ut i økt

\footnotetext{
14 NOU 2013:6, s. 62.

15 NOU 2013:6, s. 62.
} 
konkurranse av aktøren med best vilkår, dvs. NorgesGruppen. ${ }^{16}$ Det kan imidlertid stilles spørsmål om hard konkurranse basert på full videreføring av innkjøpsfordeler til forbrukerne, ville gjort det mulig å overleve i markedet for kjeder med presumptivt dårligere vilkår, jf. her ICAs exit fra markedet. En slik strategi ville neppe vært i noens interesse. Ved asymmetriske innkjøpspriser, er det da grunn til å tro at den aktøren som har dårligst vilkår vil representere en form for «prisgulv» i markedet. Aktører med bedre vilkår vil simpelthen ikke ha incentiver til å underkutte denne aktøren for mye (selv om man har mulighet), siden dette på sikt sannsynligvis ville ført til sistnevntes exit fra markedet. En bedre strategi er da å legge seg tett på/matche denne aktørens priser, i forvissning om at man vil generere et betydelig overskudd gjennom de rabattene man er tilstått i forhandlingene. Eksempelvis vil KIWI selvsagt ha interesse av å matche Rema 1000 s priser, men vil ikke ha incentiver til å konkurrere prisen betydelig lenger ned enn det Rema 1000 kan matche. Paradokset blir altså at aktøren med dårligst vilkår fungerer som et prisgulv. Innsatsen til de kjedene med best vilkår føres derfor ikke videre til konsumentene, som ville vært tilfelle i et ordinært marked. Normalt ville en forvente at en rasjonell aktør ville ha tatt ut konkurransefordelen for å øke sin markedsandel. At dette ikke skjer, kan imidlertid forklares med mulig frykt for regulatoriske virkemidler (kanskje etablert i tilstand av politisk panikk), eller frykt for at en ny og mer aggressiv konkurrent vil etablere seg dersom Coop eller Rema skulle forsvinne. ${ }^{17}$

Et sentralt poeng her er at disse forholdene gjør det vanskelig å snakke om en egentlig konkurranseulempe for de to mindre kjedene, dersom konkurransefordelen ikke tas ut i reell konkurranse. I stedet kan situasjonen bli at Rema og Coop konkurrerer mindre hardt overfor NorgesGruppen, fordi NorgesGruppen velger å konkurrere mindre hardt enn

16 Konkurransetilsynets rapport avdekket imidlertid også at for to av seksten leverandører betalte andre kjeder mindre for sitt innkjøpsvolum enn de ville ha gjort med NorgesGruppens betingelser. Bildet er således ikke entydig. Konkurransetilsynets rapport på https://konkurransetilsynet.no/wp-content/uploads/2019/11/Rapport-om-innkjøpsbetingelser_2019.pdf.

17 På dette punktet kan aktørene ha lært av SAS sitt feilgrep ved å konkurrere Braathens mot konkurs; utfallet ble at en langt mer effektiv konkurrent (Norwegian) ble etablert. 
det konkurransefordelen gir dem mulighet til. ${ }^{18}$ Coops og Remas konkurranseulempe vil i så fall veltes over på kundene, samtidig som få aktører og etableringshindringer kan forsterke effekten.

Dersom kjeden med best vilkår er ineffektiv, vil dette selvsagt kunne forklare en slik konkurransesituasjon. I Norge bør man sannsynligvis også se hen til måten detaljistleddet drives på, der det skjer en betydelig duplisering av ressursbruk gjennom overetablering av utsalgssteder. ${ }^{19}$

I diskusjonen om markedet har det også vært fremhevet at asymmetriske priser representerer en etableringshindring for nye aktører, som ikke får tilgang til tilsvarende rabatter som de etablerte kjedene. På dette punktet vil kjedene kunne ha en felles interesse av å opprettholde modellen, og i stedet forsøke å tilknytte seg nykommere gjennom innkjøpssamarbeid. Leverandørene på sin side vil neppe ha noen egeninteresse i å ekskludere nykommere.

Etter denne beskrivelsen av forhandlinger, kontrakter og mulige implikasjoner på konkurransen, er det vanskelig å stille noen form for diagnose, dvs. påpeke en form for dysfunksjonalitet i konkurransen som enkelt kan rettes opp ved konkurransepolitiske virkemidler.

Ser man på markedets struktur, er det to forhold som peker seg ut; konsentrasjon både på kjede- og leverandørnivå, og etableringshindringer. Førstnevnte kan gi opphav til koordinerte virkninger mellom kjedene (uten at dette rammes av krrl. forutsatt at det ikke er direkte eller indirekte kontakt mellom kjedene), samt mulige spørsmål om dominans og misbruk (som kan omfatte både selger- og kjøpermakt). Etableringshindringer i markedet skyldes at man må nå en viss størrelse for å kunne konkurrere effektivt, mht. innkjøp, distribusjon og lokasjoner. Samtidig spiller selvsagt importvernet en viktig rolle, som ikke behandles videre her.

18 I senere tid kan det se ut som om KIWI har overtatt rollen som «prisleder» i markedet. Prisøkningene sommeren 2019 ble f.eks. først iverksatt av KIWI, deretter fulgte de andre aktørene umiddelbart. (Påstanden bygger på samtaler med aktører både på kjede- og leverandørnivå).

19 Se f.eks. oppslag i Dagens Næringsliv 21. februar 2019, s. 4-8 med overskrift «Overetablering av dagligvarebutikker» og E24 27. februar 2019: «Kiwi-sjefen: Rema bygger seg til vekst» (https:// e24.no/naeringsliv/dagligvarebransjen/kiwi-sjefen-etter-daglivarerapporten-rema-bygger-segtil-vekst/24569670). Se også kapittel 2, Friberg et al. (2020), i denne boken. 
Ser man på markedsaktørenes adferd kan denne relateres enten til horisontale forhold (mellom konkurrenter) eller vertikale (mellom aktører på ulike trinn i omsetningskjeden). Horisontalt kan det settes spørsmålstegn ved hvor godt konkurransen mellom kjedene egentlig fungerer, uten at det i dette ligger noen antydninger om brudd på konkurranseloven. Eksempler kan være at NorgesGruppen tilsynelatende konkurrerer mindre hardt mot Rema 1000 og Coop enn det de har mulighet for, og den gjensidige tilretteleggingen for prisjegere som kan øke gjennomsiktigheten i markedet og dermed risikoen for koordinering. Samtidig legger som påpekt markedsstrukturen og også forhandlingsmodellen forholdene til rette for koordinerte virkninger. Vertikalt er det neppe grunn til å tro at det foreligger særlig mange restriksjoner (se s. 260 ff. nedenfor), men dersom det i forhandlingene med leverandørene skulle uttrykkes eksplisitte eller implisitte føringer på hvilke vilkår andre kjeder kan tilbys vil dette selvsagt være et problem.

\section{Reguleringsbehov og reguleringsmuligheter: Oversikt}

Når man vurderer reguleringsbehovet, må det gjøres et skille mellom effektivitet $\mathrm{i}$ forhandlingene (dvs. at forhandlingene maksimerer verdiskapningen i kontraktene), og konkurransepolitiske hensyn (som sikrer at verdiskapningen kommer frem til forbrukerne). Spørsmålet om reguleringsbehov er dermed todelt: For det første: Er det nødvendig å regulere forhandlingene for å legge til rette for maksimert verdiskapning? Forutsetningen er da at dagens forhandlinger og kontrakter ikke er optimale. Og for det andre: Er det konkurransepolitiske utfordringer i markedet som ikke kan løses etter gjeldende konkurranselov?

Behovet for regulering av forhandlingene har vært omstridt helt siden Steensnæs-utvalget lanserte idéen om en lov om god handelsskikk. Dette utvalgets forslag var imidlertid innrettet mot leverandørbeskyttelse, og gikk således også inn på fordelingen av verdiskapningen i kontraktene. Det forslaget som nå er fremmet for Stortinget, dreier seg i likhet med 
Dagligvarelovutvalgets forslag seg utelukkende om å legge til rette for maksimert verdiskapning i kontraktene, jf. nærmere s. 231 ff. nedenfor. ${ }^{20}$

I utgangspunktet er en slik maksimering noe partene selv skulle ha incentiver til å komme frem til, gitt rasjonell atferd. Selv om man forhandler hardt på fordelingen av overskuddet, vil det likevel være bedre å fordele en større kake enn en liten. Dersom aktørene ikke skulle opptre på en slik måte (f.eks. ved at kortsiktig gevinst vedsettes høyere enn langsiktig utvikling av forretningsforholdet), kan det være et behov for bedre å legge til rette for effektive forhandlinger. Dette er, jf. nedenfor, siktemålet med forslaget til lov om god handelsskikk.

Det har vært uttrykt skepsis mot behovet for en slik lovgivning, jf. særlig argumentet om at partene bør ha felles incentiver til å opptre på en verdimaksimerende måte. Så lenge loven ikke griper inn i fordelingen av verdier under kontrakten, og partene allerede etterlever de forpliktelsene loven oppstiller, vil den likevel kunne ha en verdi som retningsgivende for hva som faktisk bidrar til effektive kontrakter. Dette kan være alt fra bedre tilretteleggelse for investeringer til prismodeller som unngår f.eks. dobbeltmarginaliseringsproblematikk og dermed maksimerer overskuddet i verdikjeden.

Behovet for konkurransepolitisk regulering (i motsetning til regulering av forhandlingenes effektivitet), er langt mer komplekst. Hvis konkurransen $i$ et marked ikke fungerer, kan dette ha flere årsaker, som også kan opptre sammen. Markedsstrukturen er grunnleggende; jo mer konsentrert markedet er, jo dårligere vil konkurransen ofte fungere. Det norske dagligvaremarkedet fremstår som konsentrert både på leverandør- og kjedenivå. I markeder med homogene produkter vil kombinasjonen med konsentrasjon, gjennomsiktighet og jevnstore aktører kunne lede til såkalte koordinerte virkninger, dvs. at ingen vil ha incentiver til å senke pris fordi man vet at de andre aktørene følger slik at alle kommer dårligere ut.

Etableringshindringer vil være sentralt for en mulighet til å opprettholde en slik koordinert likevekt. I dagligvaremarkedet synes det å være betydelige etableringshindringer bl.a. knyttet til fysiske butikklokaler

20 Prop. 33 L (2019-2020) Lov om god handelsskikk i dagligvarekjeden. 
og landsdekkende distribusjon og logistikk. ${ }^{21}$ Samtidig vil størrelse og mulighet til å oppnå konkurransedyktige betingelser fra leverandørene være en utfordring.

Slike forhold vil knytte seg til markedets struktur og egenart. Her finnes det kun ett verktøy for konkurransemyndighetene: fusjonskontrollen. Selv om krrl. $\$ 12$ i prinsippet gir hjemmel for såkalte strukturelle tiltak (i ytterste konsekvens tvungen oppsplitting av et dominerende foretak), forutsetter dette både forutgående overtredelse av krrl. og dessuten en vurdering av proporsjonalitet. Selv om det f.eks. kunne vært fristende å pålegge NorgesGruppen å skille ut kjedehuset KIWI og ev. børsnotere dette rekker hjemmelen i $\$ 12$ neppe så langt.

Konkurransen kan også være begrenset gjennom markedsaktørenes atferd, f.eks. utveksling av informasjon horisontalt, vertikale restriksjoner inntatt i kontrakter eller etter en gjensidig forståelse, ev. ensidig bruk av markedsmakt. Slike forhold vil imidlertid fanges opp av konkurranseloven $\$ \$ 10$ og 11. Konkurransebegrensende atferd er det altså kun grunn til å regulere dersom den ikke fanges opp av konkurranseloven eller terskelen for å gripe inn etter loven er for høy.

For konkurransepolitisk regulering eksisterer det også EØS-rettslige skranker iht. EØS-konkurranseloven $\$ 7$. Andre ledd forbyr anvendelse av nasjonal konkurranselovgivning som er strengere enn EØS art. 53 på avtaler og samordnet praksis, noe som i utgangspunktet er til hinder for en strengere konkurranserettslig regulering av krrl. $\$ 10 .{ }^{22}$ For regulering av ensidig adferd eksisterer det derimot ikke skranker mot strengere nasjonal lovgivning. ${ }^{23}$

Dette innebærer at EØS-avtalen ikke er til hinder for en regulering som forbyr en leverandør å ta eller kreve diskriminerende eller ulike priser, mens det ikke kan vedtas et generelt forbud mot avtaler som inneholder diskriminerende eller ulike vilkår.

Den naturlige hjemmelen for konkurransepolitisk regulering er krrl. $\$ 14$. Bestemmelsen lyder:

21 Importvernet bør selvsagt også nevnes, siden det representerer en betydelig etableringshindring for utenlandske kjeder. Denne problemstillingen er det imidlertid avgrenset mot her.

22 Skrankene her er identiske under EØS-avtalen og EU-reglene.

23 Om hva som ligger i begrensningen til «ensidig adferd» se Gjendemsjø/Anchustegui (2017), s. 11. 
Dersom det er nødvendig for å fremme konkurransen i markedene, kan Kongen ved forskrift gripe inn mot vilkår, avtaler og handlinger som begrenser eller er egnet til å begrense konkurransen i strid med lovens formål.

Kompetansen er delegert til Nærings- og fiskeridepartementet. ${ }^{24}$ Det er således departementet som gir forskrift, som vanligvis utarbeides og forberedes av Konkurransetilsynet. Hittil er det gitt to forskrifter under $\$ 14$; om bonusprogrammer i innenriks luftfart og om eiendomsannonsering over internett. ${ }^{25}$ Førstnevnte ble opphevet i 2013.

Hjemmelen tar sikte på å fylle et hull i konkurranselovens EØSharmoniserte forbudsregler. Behovet for en slik hjemmel som kunne utfylle lovens forbudsbestemmelser ble først påpekt av et mindretall i lovutvalget som forberedte krrl. 2004. Denne fraksjonen pekte først på svakheter i forbudet mot misbruk av dominerende stilling, før behovet for en særlig hjemmel ble løftet frem:

Bestemmelsen forbyr ikke skadelig atferd når det ikke kan påvises ensidig eller kollektiv markedsdominans. Ei heller gir den konkurransemyndighetene hjemmel til å (forskrifts-)regulere rammevilkårene generelt for alle aktører. Dette kan for eksempel være aktuelt når samfunnsøkonomiske hensyn tilsier at insentivene til alle aktørene i bestemte markeder eller bransjer bør reguleres. Etter disse medlemmenes oppfatning er den viktigste grunnen til at det er behov for en hjemmel til å regulere markedene gjennom generelle bestemmelser gitt i forskrift, at det kan være behov for å iverksette konkurransefremmende tiltak i et marked selv om det ikke foreligger dominans eller kan bevises utilbørlig utnyttelse av dominerende stilling. Det vil for eksempel kunne være tilfelle dersom det i hele eller store deler av en bransje har utviklet seg en salgs- eller innkjøpspolitikk som stenger konkurransevillige aktører ute eller som låser kunder inne på en slik måte at konkurransen begrenses uten at det kan påvises at noen aktør har en dominerende posisjon eller at de har samarbeidet innbyrdes. I slike tilfeller vil det kunne være aktuelt å gripe inn og forby en innarbeidet konkurransebegrensende praksis i bransjen for å 
legge til rette for å stimulere til effektiv konkurranse. En generell regulering kan også være mest hensiktsmessig fordi den sikrer like rammebetingelser for alle aktører i vedkommende bransje. ${ }^{26}$

Synspunktene vant gehør hos departementet, som sluttet seg til mindretallets vurdering. ${ }^{27}$ Bestemmelsen er ment brukt i markeder der det har utviklet seg en praksis som er konkurransebegrensende uten at forbudene i $\$ \$ 10$ og 11 nødvendigvis kommer til anvendelse. ${ }^{28}$ Det er imidlertid ikke slik at en mulig anvendelse av $\$ 10$ er til hinder for bruk av $\$ 14$ - i så fall ville den vært uten praktisk betydning.

I NOU 2012:7, der det foretas en generell gjennomgang av virkemidlene i konkurranseloven, fremheves $₫ 14$ som viktig for å regulere ensidige handlinger der det ikke foreligger dominerende stilling. ${ }^{29}$ Bestemmelsen ble styrket ved lovendringen 1. januar 2014, ved at Konkurransetilsynet fikk mulighet til å pålegge opphør også ved overtredelser av $\$ 14$-forskrifter (dvs. at $\$ 12$ også omfatter brudd på $\$ 14$-forskrifter).

Samlet sett innebærer dette at krrl. $\$ 14$ representerer et fleksibelt reguleringsverktøy for tilfeller hvor konkrete konkurranseproblemer ikke kan løses ved anvendelse av lovens forbudsbestemmelser.

Bestemmelsen er knyttet opp mot noen spesifikke vilkår. ${ }^{30}$ Det sentrale er at det må foreligge «vilkår, avtaler og handlinger» som «begrenser eller er egnet til å begrense» konkurransen. Ved første øyekast kan hjemmelen virke overflødig ved siden av $\$ \$ 10$ og 11 , som nettopp retter seg mot avtaler eller handlinger med konkurransebegrensende virkning. I tilfeller hvor det ikke foreligger individuell eller kollektiv dominans, vil bestemmelsen imidlertid kunne være viktig, først og fremst der konkurransestridige handlinger eller adferd ikke kommer til uttrykk i avtaler eller samordning mellom foretak. Samtidig er terskelen lavere etter $\$ 14$ enn etter misbruksforbudet; det er tilstrekkelig at adferden er egnet til å begrense konkurransen. Man behøver m.a.o. ikke å etablere at det foreligger misbruk av en dominerende stilling.

\footnotetext{
26 NOU 2003:12, s. 69.

27 Ot. prp. nr. 6 (2003-04), s. 73.

28 Ot. prp. nr. 6 (2003-04), s. 228.

29 NOU 2012:7, s. 159.

30 Se nærmere Evensen/Sæveraas (2009), s. 463 ff.
} 
At adferden også kan omfattes av forbudsbestemmelsene, er ikke til hinder for at man benytter $\$ 14$. Dette kan f.eks. være praktisk der man etter $\$ 11 \mathrm{er}$ nødt til å påvise en kollektivt dominerende stilling, noe som kan være vanskelig, eller der inngrep i enkeltsaker etter $₫ 10$ fremstår som lite praktisk eller effektivt. Består det et reelt konkurransemessig problem i et slikt marked, vil en konkret regulering etter $₫ 14$ kunne være mer effektivt enn inngrep gjennom enkeltsaker.

Videre må forskrifter ta sikte på å «fremme konkurransen». Dette vilkåret vil normalt være oppfylt der det er tale om å gripe inn med forbud mot tiltak med konkurransebegrensende virkning. Derimot vil ikke $\$ 14$ gi adgang til å regulere et marked utelukkende for å skape økt konkurranse, hvis det ikke foreligger en konkret konkurranseskadelig (eller potensielt konkurranseskadelig, jf. «egnet til»), praksis blant foretakene.

Endelig kreves det at adferden det gripes inn mot er i strid med lovens formål, jf. $\$ 1$. Dette innebærer at det ikke vil kunne gripes inn mot forhold som, tross deres konkurransebegrensende virkning, gir effektivitetsgevinster som mer enn oppveier tapet. Ut fra den gjennomgående harmoniseringen av konkurranseloven med EØS-reglene innebærer dette sannsynligvis at det kan gripes inn dersom fordelene ikke føres videre til forbrukerne, jf. formuleringen i $\$ 10$ tredje ledd. Paragraf 14 er som utgangspunkt en forbudshjemmel. Bestemmelsen gir imidlertid ikke bare hjemmel til å nedlegge forbud, men også til å pålegge positive tiltak. Dette eksemplifiseres ved forskriften om tilgang til eiendomsannonsering på internett, der aktører pålegges positive forpliktelser til å gi tilgang til tjenesten. På denne måten kan hjemmelen sammenlignes med Konkurransetilsynets alminnelige påleggskompetanse i $\$ 12$.

Oppsummeringsvis gir krrl. $\$ 14$ hjemmel til å forby eller regulere adferd som begrenser eller er egnet til å begrense konkurransen. Terskelen for $\$$ 14-regulering er lavere enn for forbudsvedtak etter krrl. $\$ 12$, siden det da må etableres overtredelse av en forbudsbestemmelse. Dessuten gir $\$ 14$ hjemmel for å forby ensidige handlinger som skader konkurransen uten at det er nødvendig å påvise en dominerende stilling. 


\section{Idéen bak lov om god handelsskikk - og hva kan forventes?}

Forhandling av en kontrakt kan sies å ha to elementer: Utformingen av samarbeidet og fordelingen av overskuddet kontrakten genererer. Aktørene vil ha felles interesse $\mathrm{i}$ at samarbeidet skal generere så store verdier som mulig, og rasjonelle aktører vil nå frem til optimale løsninger. Forhandlinger er altså grunnleggende effektive. Dette fordi det er partene selv som er nærmest til, og normalt også har incentiver til, å komme frem til de mest effektive løsningene. For at dette skal slå til, er det imidlertid flere forutsetninger som må være til stede, jf. nedenfor. Dersom disse ikke er til stede, vil ikke det resultatet forhandlingene genererer nødvendigvis være effektivt. Når det gjelder fordelingen av verdiene som skapes, vil partene ha motsatte interesser. ${ }^{31}$ Denne fordelingen er det imidlertid ikke grunn til å legge seg opp i, med mindre det er ønskelig å gi én part en særlig beskyttelse. Her fremstår Steensnæsutvalget og Dagligvarelovutvalget som uenige; mens Steensnæsutvalget ønsket en lov som ville beskytte leverandørene, var Dagligvarelovutvalget kun opptatt av å legge til rette for effektive forhandlinger. ${ }^{32}$ Fra et forbrukerperspektiv er det på det rene at dagligvarekjedene fungerer som forbrukernes agenter, dvs. at jo mer av verdiskapningen som havner hos kjedene, jo mer kan føres videre til forbrukerne gjennom lavere priser. Forutsetningen da er selvsagt at konkurransen mellom kjedene fungerer slik at overskuddet ikke avleires hos kjedene og bidrar til økt utbytte og ineffektiv drift. Arbeidsdelingen mellom konkurransepolitikken og effektivitet i forhandlingene kan illustreres som følger:

31 Se nærmere NOU 2013:6 pkt. 6.3.2 om rimelighet vs. effektivitet. I litteraturen om forhandlinger er dette kjent som skillet mellom «integrasjonsforhandlinger» og «fordelingsforhandlinger».

32 EU-direktivet om «unfair trading practices in business-to-business relationships in the agricultural and food supply chain» (Parlaments- og Rådsdirektiv (EU) 2019/633), er mer utydelig på dette punktet, selv om direktivet på mange punkter er sammenfallende med lov om god handelsskikk. Det er fremdeles usikkert om direktivet vil bli innlemmet i EØS-avtalen. 


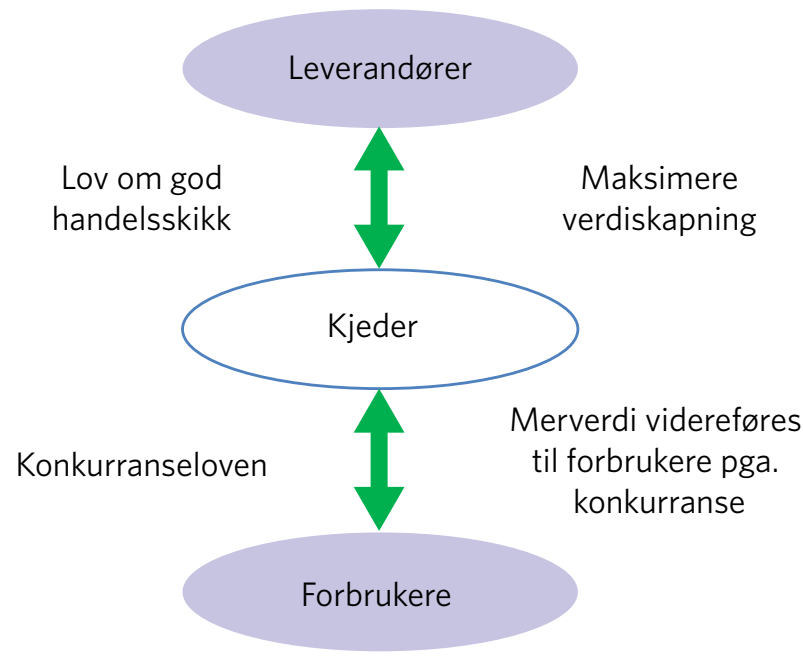

Figur 1 Arbeidsdeling mellom lov om god handelsskikk og konkurransepolitikken.

Dagligvarelovutvalgets forslag til lov om god handelsskikk søker å redusere reguleringen til det som er nødvendig for å legge til rette for effektive forhandlinger - i motsetning til f.eks. å regulere forhandlingsresultatet direkte eller å beskytte en presumtivt «svakere» part i forhandlingene. ${ }^{33}$

Matmaktutredningen (NOU 2011:4) gjennomførte en empirisk spørreundersøkelse der man søkte å kartlegge misnøye knyttet til forhandlingene. Denne ga inntrykk av at det var mange klager på avtaler man var misfornøyd med, og det var vanskelig å skille ut hva som var reelle problemer i den forstand at de hadde betydning for effektiviteten i kontraktene. ${ }^{34}$ Likevel var det indikasjoner på ineffektivitet, f.eks. at usikkerhet om forpliktelser kunne føre til at investeringer ikke ble foretatt. Selv om slik dysfunksjonalitet normalt vil håndteres av alminnelige rettsregler (som f.eks. prinsippet om at avtaler skal holdes), vurderte utvalget det slik at det kunne være et behov for lov om god handelsskikk, dersom det er slik at forhandlingene tross det man skulle forvente ikke gir effektive resultater.

\footnotetext{
33 NOU 2013:6 s. 116 (pkt. 13.6.1).

34 NOU 2013:6, s. 67 (pkt. 7.4 andre avsnitt).
} 
Nærings- og fiskeridepartementets forslag til lov om god handelsskikk i Prop. L 33 (2019-2020) inneholder mest språklige justeringer av forslaget fra Dagligvarelovutvalget. Forslaget er konsistent med idéen om aktørnøytralitet og effektive forhandlinger. Utover en generell formulering av god handelsskikk i $\$ 4$ («Forretningsforhold skal bygge på redelighet, forutberegnelighet og gjensidig respekt for immaterielle rettigheter»), inneholder forslaget spesifikke bestemmelser om skriftlighet og fullstendighet $(\$ 5)$, informasjon i forhandlinger $(\$ 6)$ beskyttelse av forretningshemmeligheter $(\$ 7)$, beskyttelse av investeringer $(\$ 8)$, svinn og reklamasjoner $(\$ 9)$, oppsigelse og delisting $(\$ 10)$ og angivelse av forretningsmetoder som ikke er tillatt $(\$ 11)$. Sistnevnte er mer eller mindre identisk med straffeloven (2005) $\$ 263$ om straffbare trusler.

Bestemmelsene er først og fremst ment å skape forutberegnelighet i kontraktsrelasjonene. Dette kan selvsagt hevdes å være overflødig, siden det følger av kontraktsrettens alminnelige prinsipper at avtaler skal holdes, jf. også Norske Lov (1687) 5-1-2. Loven går likevel lenger enn dette, siden det dels oppstilles krav om hva som skal være regulert i avtalen (f.eks. delisting), og utvider også immaterialrettens beskyttelse for forretningshemmeligheter.

Lovens kanskje viktigste potensial ligger i opprettelsen av et Dagligvaretilsyn $^{35}$ som kan stå for en helhetlig tilnærming og håndhevelse av lovens bestemmelser - selv om flere av forpliktelsene allerede må anses å følge av gjeldende rett. I høringsnotatet av 26. april heter det:

En viktig begrunnelse for lovforslaget, er å samle reglene om god handelsskikk for dagligvareaktørene, som nå er spredt ut over flere regelverk og i ulovfestet rett, i én lov. Videre bør loven håndheves av et organ med en helhetlig tilnærming og spesialkompetanse innenfor lovens bestemmelser og denne bransjen. Et offentlig tilsynsorgan med tilgang til et bredt spekter av virkemidler vil være en forutsetning for å oppnå lovens formål. ${ }^{36}$ 
Det er neppe grunn til å forvente de helt store endringene i måten kontrakter forhandles på, eller i kontraktenes innhold. At det etableres et eget tilsyn som fokuserer på nettopp disse aspektene i kontraktene, må imidlertid anses å ha en preventiv effekt dersom det først skulle foreligge brudd på standarden. Samtidig vil nok saker for Dagligvaretilsynet være av interesse for media, slik at loven kan få en sterkere effekt. ${ }^{37}$ Uansett er nok suksessraten avhengig av personen som bekler rollen som direktør, jf. erfaringene i England der Christine Tacon synes å ha oppnådd respekt både hos kjeder og leverandører.

\section{Konkurransepolitikk: Virkemidler i konkurranseloven}

Konkurranseloven $₫ 11$ forbyr misbruk («utilbørlig utnyttelse») av dominerende stilling. Bestemmelsen skal forstås identisk med det tilsvarende misbruksforbudet i EØS-avtalen art. 54 og Traktaten om den Europeiske Unions Virkemåte art. 102. ${ }^{38}$ Dette innebærer at praksis fra EU-domstolen er avgjørende for forståelsen av bestemmelsen.

Definisjonen på dominerende stiling ble gitt av EU-domstolen i United Brands-saken. Her heter det at dominerende stilling innebærer:

...a position of economic strength enjoyed by an undertaking which enables it to prevent effective competition being maintained on the relevant market by giving it the power to behave to an appreciable extent independently of its competitors, customers and ultimately of its consumers. ${ }^{39}$

Det er i alminnelighet lagt til grunn at $40 \%$ markedsandel representerer en slags nedre grense for dominans, men det kan ikke utelukkes at en slik stilling kan etableres også under denne terskelen. ${ }^{40}$ Et viktig forhold

37 Jf. effektene av Konkurransetilsynets offentliggjøring av prisforskjeller i november 2019.

38 Ot.prp. nr. 6 (2003-04), s. 224.

39 Sak 27/76 United Brands, [1978] ECR 207 (ECLI:EU:C:1978:22), prem. 65.

40 Se nærmere Hjelmeng/Sørgard (2014), s. 255-56. I sak C-95/o4 British Airways v Kommisjonen, [2007] ECR I-2331 (ECLI:EU:C:2007:166) ble dominans etablert med 39,7 \% markedsandel. 
er sammenhengen mellom dominansterskelen og hva som utgjør et misbruk; mange av de typer adferd som karakteriseres som misbruk, vil bare være skadelige for konkurransen dersom det foreligger markedsmakt. ${ }^{41}$ Det er også eksempler på at dominansterskelen har påvirket det nærmere innholdet i misbruksvurderingen; når det for eksempel ikke kreves bevis for at et foretak som gjør seg skyldig i prisdumping eller rovprising er i stand til å sette monopolpris (såkalt «recoupment» etter at konkurrenter er drevet ut fra markedet), skyldes dette nødvendigvis at en slik evne ligger implisitt i konklusjonen om dominans. Disse sammenhengene er særlig viktige dersom det vurderes å gi misbruksforbudet anvendelse også på ikke-dominerende foretak.

Samtidig eksisterer det åpenbart en hårfin balanse mellom selgermakt og kjøpermakt i det norske markedet. Kjøpermakt kan oppheve en dominerende stilling på leverandørnivå, og kjøpermakt kan også misbrukes. Om det eksisterer kjøpermakt eller selgermakt vil dette også kunne ha avgjørende betydning for spørsmålet om hvordan misbruksforbudet $\mathrm{i}$ krrl. $\$ 11$ slår inn. Det er flere indikasjoner på kjøpermakt i det norske dagligvaremarkedet, bl.a. at leverandørene ikke har maktet å kvitte seg med en forhandlingsstruktur som neppe er til fordel for dem. Jeg går ikke nærmere inn på disse spørsmålene, men det er klart at spørsmålet om hvem som er dominerende vil være avgjørende for Konkurransetilsynets inngrepsmuligheter i markedet. ${ }^{42}$

Misbruksforbudet kan anvendes både på individuell og kollektivt dominerende stilling. Vedr. det siste finnes det imidlertid begrenset rettspraksis, og det virker anstrengt å skulle anvende dette konseptet i det norske dagligvaremarkedet.

Misbruk defineres gjerne som adferd som avviker fra normal forretningspraksis. I Hoffmann-La Roche ga Domstolen følgende beskrivelse av hva som utgjør et misbruk:

\footnotetext{
41 Se Guidance on the Commission's enforcement priorities in applying Article 82 of the EC Treaty to abusive exclusionary conduct by dominant undertakings, OJ C 45, 24.2.2009, s. 7, pkt. 10 og 11. 42 Se drøftelsen av dette i lagmannsrettens dom i Tine-saken; LB-2009-89085 pkt. 11 d). Vurderingen fikk tilslutning av Høyesterett, se Rt. 2011 s. 910 prem. 65.
} 
The concept of abuse is an objective concept relating to the behaviour of an undertaking in a dominant position which is such as to influence the structure of a market where, as a result of the very presence of the undertaking in question, the degree of competition is weakened and which, through recourse to methods different from those which condition normal competition in products or services on the basis of the transactions of commercial operators, has the effect of hindering the maintenance of the degree of competition still existing in the market or the growth of that competition. ${ }^{43}$

Diskriminerende adferd er nevnt i ordlyden i $₫ 11$ bokstav c), der det som eksempel på misbruk nevnes «å anvende overfor handelspartnere ulike vilkår for likeverdige ytelser og derved stille dem ugunstigere i konkurransen». Dette kommer jeg tilbake til nedenfor.

Det vil bare foreligge overtredelse hvis foretaket ikke er i stand til å fremføre en saklig og objektiv begrunnelse for sin adferd. Hvis det først foreligger en vesentlig forskjellsbehandling som også har konkurransevridende virkninger mellom kundene, skal det nok en del til før praksisen vil kunne begrunnes. Typiske tilfeller vil være ulike rabattordninger med lojalitetsskapende virkninger, hvor forskjellene overfor den enkelte kunde kan begrunnes i relasjonsspesifikke forhold. Rettspraksis gir også eksempler på at objektive faktorer som ulikheter i transportkostnader, avgifter, markedsføringsvilkår og konkurranseintensitet vil kunne rettferdiggjøre også geografisk prisdiskriminering. ${ }^{44}$ Tilsvarende uttalte Domstolen i STIM at ulikheter mellom offentlige og private kringkastere kunne anføres som objektiv begrunnelse for ulike beregningsmodeller for opphavsrettsvederlag. ${ }^{45}$

Det norske dagligvaremarkedet er konsentrert, både på leverandør- og kjedesiden. Det vil absolutt kunne være et potensial for å anvende $₫ 11$ på dominerende foretak, enten dette gjelder leverandører som karakteriseres som dominerende eller kjeder - der dominans kan diskuteres både på detaljistleddet og på innkjøpssiden. ${ }^{46}$ Nedenfor diskuteres anvendelsen

\footnotetext{
43 Sak 85/76 Hoffmann-La Roche, [1979] ECR 461 (ECLI:EU:C:1979:36), prem. 91.

44 Sak 27/76, United Brands v Kommisjonen, [1978] ECR 207 (ECLI:EU:C:1978:22), prem. 22.

45 Sak C-52/o7 Kanal 5 og TV4 v STIM, [2008] ECR I-9275 (ECLI:EU:C:2008:703), prem. 47.

46 Nærmere om kjøpermakt under misbruksforbudet se Anchustegui (2017).
} 
av $\S 11$ på de problemstillinger og reguleringsidéer som er identifisert i innledningen.

Også krrl. $§ 10$ om konkurransebegrensende samarbeid vil selvsagt være relevant i det norske dagligvaremarkedet. Som nevnt ovenfor benyttet Konkurransetilsynet allerede i $2006 \$ 10$ som brekkstang for å få brakt kjedenes informasjonsutveksling gjennom AC Nielsen til opphør. Gjennomsiktighet mellom kjedene og dermed koordinerte virkninger er også en aktuell problemstilling i tilknytning til gjensidig tilrettelegging for såkalte prisjegere.

Endelig vil $₫$ 1o kunne fange opp vertikale restriksjoner, dvs. restriksjoner avtalt mellom uavhengige foretak på ulike ledd i verdikjeden. De fleste slike restriksjoner er unntatt fra forbudet etter forskriften om vertikale restriksjoner (forutsatt en markedsandelsterskel på $30 \%$ ), mens prisbindinger i form av faste priser eller minimumspriser rammes av forbudet. Disse forholdene kommer jeg tilbake til i på s. 260 ff. nedenfor.

\section{Konkurransepolitisk regulering}

\section{Innledning}

Innledningsvis er det pekt på fire mulige reguleringer av konkurransepolitisk art: forbud mot prisdiskriminering, regulering av tilgang til distribusjon, strengere tilnærming til vertikale restriksjoner og tak på eller restriksjoner knyttet til markedsandel. En drøftelse av slike ulike virkemidler kan imidlertid bli hengende litt i luften, all den tid det ikke er mulig innenfor rammene av dette kapittelet å stille en konkurransepolitisk diagnose på at noe bestemt er galt og eventuelle årsaker til dette. Konkurransetilsynets avdekking av asymmetri i innkjøpspriser representerer f.eks. et faktum som må vurderes nærmere både mht. virkninger, årsaker og betydning for konkurransen samt opp mot de rettslige terskler som finnes i konkurranseloven. Innenfor rammene av dette arbeidet kan det beskrives hvilke rettslige terskler som gjelder, og det kan antydes mulige virkninger av, og ikke minst utfordringer knyttet til, ulike reguleringer. Gjennomgående vurderes først bestående virkemidler i konkurranseloven, før jeg ser nærmere på spesifikke reguleringsmuligheter. 


\section{Forbud mot prisdiskriminering}

\section{Prisdiskriminering etter gjeldende konkurranselov}

I prinsippet kan asymmetriske priser angripes på to måter etter $\$$ 11: For det første som klassisk annenlinjes prisdiskriminering, eller som misbruk av kjøpermakt. Sistnevnte innebærer at en dominerende kjøper benytter kjøpermakten til å påføre konkurrenter en konkurranseulempe («raising rivals' costs»). ${ }^{47}$ Misbruk i en slik relasjon må forutsette at det foreligger eksplisitt eller implisitt enighet eller krav om at konkurrenter skal ha dårligere vilkår. Det er vanskelig å karakterisere det som misbruk at en aktør fremforhandler så gode vilkår som mulig for seg selv - med mindre det skulle være tale om en form for omvendt predasjon. I det følgende fokuseres det på diskriminering og dominans på selgersiden.

Ved vurdering av prisdiskriminering under misbruksforbudet er det helt essensielt å definere skadehypotesen riktig. Det finnes flere former for diskriminering som kan omfattes av misbruksforbudet i konkurranseretten, og som kan være relevant for den foreliggende problemstillingen:

1. Diskriminering mellom kunder for å svekke en konkurrent (slik at konkurrentens kunder gis bedre vilkår)

2. Diskriminering mellom kunder der det dominerende foretaket ikke selv er til stede på nedstrømsmarkedet (såkalt ren annenlinjes diskriminering). ${ }^{48}$

Primært gjelder problemstillingen knyttet til asymmetriske innkjøpspriser i dagligvaremarkedet ren annenlinjes diskriminering, jf. kategori nr. 2. I den utstrekning det foreligger diskriminering som også fører til at mindre leverandører stenges ute eller hindres i å ekspandere, vil det også kunne foreligge førstelinjesvirkninger (kategori nr. 1). Hypotesen kunne da være at den største kjeden promoterer merkevarer fra leverandører hvor de oppnår størst prisfordel, som i sin tur kan hevdes å styrke disse

47 Se nærmere Anchustegui (2017), s. 241 ff. om «buyer induced price discrimination».

48 I tillegg kan misbruksforbudet ramme nasjonalitetsbestemt forskjellsbehandling og diskriminering mellom egen nedstrømsvirksomhet og konkurrenter som er avhengige av å kjøpe tjenester fra det dominerende foretaket (typisk tilgang til infrastruktur). Ingen av disse kategoriene behandles nærmere her. 
merkevarene også i andre kjeder. ${ }^{49}$ En slik hypotese fremstår imidlertid som svært usikker, siden leverandøren også vil kunne tape salg i andre kjeder til mindre leverandører, og "promoteringseffekten» dessuten vil være begrenset til den favoriserte kjeden. Dessuten kan det selvsagt være et utslag av nettopp ønsket konkurranse mellom leverandører, så lenge det ikke går over i predasjon. En annen førstelinjeshypotese kunne være at rabattene som ytes anses som en form for lojalitetsrabatter, for eksempel dersom rabattene ytes retroaktivt først når et bestemt kvantum er oppnådd over en viss periode..$^{\circ}$ En tredje skadehypotese kan være at prisene representerer predasjon, men heller ikke her er det indikasjoner på at dette skulle være tilfelle.

Forbud mot ren annenlinjes diskriminering er omstridt, dels fordi skadevirkningene for konkurransen og forbrukerne ikke er entydige, dels fordi vurderingen i praksis synes å fokusere mer på «like vilkår» og rettferdighet enn konkurranse og effektivitet, og endelig at ren annenlinjes diskriminering ikke nødvendigvis kan forklares som rasjonell atferd fra et dominerende foretak (i fravær av førstelinjesvirkninger)..$^{1}$

Det foreligger også meget begrenset med praksis om ren annenlinjes diskriminering; i de langt fleste sakene hvor diskriminering har vært oppe har det vært i kombinasjon med andre misbruksformer. O’Donoghue/ Padilla oppsummerer som følger:

49 Se f.eks. høringsuttalelse fra kolonial.no til Rapport om etableringshindringer i dagligvaresektoren, s. 3 (https://www.regjeringen.no/contentassets/4c26fo95eaaa4f 9 c9doo $1762 \mathrm{f} 78 \mathrm{bcc} 72 /$ kolonial.no-as.pdf?uid=Kolonial.no_AS.pdf).

50 Se allerede sak 85/76 Hoffmann-La Roche \& Co. AG v Kommisjonen [1979] ECR 461 (ECLI:EU:C:1979:36), prem. 90, der Domstolen sidestiller en lojalitetsrabatt (knyttet til eksklusivitet) med diskriminering. Virkningene av retroaktivitet må vurderes konkret. Dersom en kunde først oppnår rabatt på hele kvantumet der vedkommende har nådd et salgsmål som ligger opp mot kundens estimerte behov over en periode («all-unit rebate»), vil dette f.eks. kunne representere et misbruk.

51 Se O’Donoghue og Padilla (2013), s. 784 ff. Også generaladvokat Nils Wahl uttrykker ganske bastant at incentiver til å diskriminere ikke foreligger, jf. forslag til avgjørelse i MEO avsnitt 76: «a distinction must immediately be drawn between undertakings that are vertically integrated and will therefore have an interest in displacing competitors on the downstream market and those that have no such interest.» (Sak C-525/16, ECLI:EU:C:2017:1020). Et poeng her er at de vilkårene som ble vurdert i MEO var fastsatt av leverandør, i motsetning til det som diskuteres i det norske dagligvaremarkedet der vilkårene variere iht. forhandlingsstyrke og forhandlingsdyktighet fra kjedenes side. 
...in each case in which secondary-line discrimination was considered an abuse in itself, the dominant firm was also found guilty of a series of other abuses. In many cases, the other abuse was the primary conduct complained of and the secondary-line discrimination merely a logical consequence of that conduct. This suggests that the Community institutions are generally unlikely to take action where the only allegation is that the dominant firm has charged different prices to non-associated companies. ${ }^{52}$

Det er likevel ingen tvil om at ren annenlinjes diskriminering representerer en selvstendig misbruksform. I MEO oppsummerer Domstolen som følger:

In accordance with the case-law of the Court, the specific prohibition of discrimination under subparagraph (c) of the second paragraph of Article 102 TFEU is intended to ensure that competition is not distorted in the internal market. The commercial behaviour of the undertaking in a dominant position may not distort competition on an upstream or a downstream market, in other words, between suppliers or customers of that undertaking. Co-contractors of such undertakings must not be favoured or disfavoured in the area of the competition which they practise amongst themselves. Thus, it is not necessary that the abusive conduct affects the competitive position of the dominant undertaking itself on the same market in which it operates, compared with its own potential competitors..$^{53}$

Fokuset til diskrimineringsforbudet (mot ren annenlinjes diskriminering) er således å hindre at handelspartnere til dominerende foretak påføres ulemper i konkurransen med hverandre.

Konseptet diskriminering under misbruksforbudet krever for det første en vurdering av om de aktuelle transaksjoner er sammenlignbare eller ikke, det vil si at forhold knyttet til den enkelte kunde, typisk betalingssikkerhet eller kvantum, vil spille inn. ${ }^{54}$ Egenskaper ved kundene vil

52 Op.cit. s. 814 .

53 Se sak C-525/16 MEO (ECLI:EU:C:2018:270), prem. 24.

54 Se nærmere O'Donoghue og Padilla (2013), s. 792: «...the key issue is whether the "transactions" are "equivalent", which suggests that the commercial context of the compared transactions plays a paramount role.» 
kunne føre til at situasjonene ikke anses som sammenlignbare; typisk gjelder dette der enkelte kunder kjøper større kvanta og dette gjenspeiles i kostnadsbesparelser hos det dominerende foretaket. For eksempel kan man ikke si at en opphavsrettsorganisasjon som benytter ulike modeller for å kalkulere vederlag til ulike kunder nødvendigvis diskriminerer, hvis ulikheter ved kundene (f.eks. at én er en offentlig finansiert allmennkringkaster og en annen er en reklamefinansiert kommersiell kanal), tilsier ulike modeller.55

Videre kreves det at diskrimineringen er av en slik art at handelspartneren påføres en konkurranseulempe. På dette punktet vil det bl.a. ses hen til graden av diskriminering, hvor stor andel av den diskriminertes kostnader det gjelder osv., jf. Domstolens nylige veiledning om dette i MEO-saken..$^{6}$

Vurderingen må iht. prem. 28 «examine all the relevant circumstances in order to determine whether price discrimination produces or is capable of producing a competitive disadvantage». I prem. 30 listes det følgende kriterier:

...the competition authority or the competent national court is required to take into account all the circumstances of the case submitted to it. It is open to such an authority or court to assess, in that context, the undertaking's dominant position, the negotiating power as regards the tariffs, the conditions and arrangements for charging those tariffs, their duration and their amount, and the possible existence of a strategy aiming to exclude from the downstream market one of its trade partners which is at least as efficient as its competitors.

I tilknytning til siste setning viser Domstolen til Intel-dommen. ${ }^{57}$ Den saken gjaldt utestengende misbruk rettet mot en konkurrent, men det sentrale her vil være at konkurranseulempe ikke nødvendigvis vil vurderes for det diskriminerte foretaket; for at det skal foreligge en konkurranseulempe må vilkårene være slik at de utgjør en konkurranseulempe for et like effektivt foretak som det favoriserte. Tilnærmingen med en

57 Sak C-413/14 P Intel v Commission (ECLI:EU:C:2017:632), prem. 139. 
«as efficient competitor» kan ses på som et generelt utviklingstrekk ved Domstolens art. 102-praksis.

Kravet om konkurranseulempe har blitt håndhevet med varierende styrke av Domstolen i ulike situasjoner. For eksempel har det knapt blitt stilt krav om slik «ulempe» i saker hvor det har dreid seg om forskjellsbehandling etter nasjonalitet,,$^{58}$ eller diskriminering som tar sikte på å hindre «lekkasjer» mellom ulike handelsområder.59 Tilsvarende gjelder saker hvor adferden anses (også) å falle i en annen misbrukskategori, for eksempel lojalitetsrabatter. I British Airways, der misbruket først og fremst hadde karakter av lojalitetsrabatter, påpekte EU-domstolen at det var tilstrekkelig å etablere at adferden «tends to» vri konkurransen, og at «In such a situation, it cannot be required in addition that proof be adduced of an actual quantifiable deterioration in the competitive position of the business partners taken individually». ${ }^{60}$ Dette er på linje med MEO, der Domstolen benytter uttrykket «capable to».

Ikke enhver forskjellsbehandling vil fanges opp av forbudet. For det første vil ikke all forskjellsbehandling kvalifisere som «diskriminering» etter bestemmelsen. Typisk vil forskjeller som kan begrunnes saklig og objektivt, i tråd med EU-rettens alminnelige diskrimineringskonsept, ikke fanges opp. Typisk kan dette gjelde kostnadsbesparelser. ${ }^{61}$ Selve konseptet diskriminering fremstår som ganske rett frem. I praksis kan det imidlertid være utfordrende å anvende, særlig fordi det kan være tvil om hva som utgjør sammenlignbare transaksjoner og også hva som utgjør ulike vilkår.

58 Se for eksempel sak 27/76 United Brands, [1978] ECR 207 (ECLI:EU:C:1978:22), jf. videre Whish/ Bailey (2018), s. 781). Forbudet mot diskriminering iht. nasjonalitet virker parallelt med det generelle EØS-rettslige prinsippet om ikke-diskriminering, jf. art. 4, og også de generelle reglene om fri bevegelighet for varer, tjenester, personer og kapital. Se også Kommisjonens vedtak i Deutsche Post ([2001] OJ L 331/40, avsnitt 120-134), om diskriminerende vilkår for postforsendelser avhengig av opprinnelse.

59 Se for eksempel sak T-228/97 Irish Sugar [1999] ECR II-2969 (ECLI:EU:T:1999:246).

60 Sak C-95/04 British Airways v Kommisjonen (ECLI:EU:C:2007:166), prem. 145, jf. også sak C-52/o7 Kanal 5 og TV4 v STIM, [2008] ECR I-9275 (ECLI:EU:C:2008:703), prem. 44.

61 Det er ikke helt klart hvordan diskrimineringskonseptet forholder seg til læren om «objektiv begrunnelse», dvs. om en relevant kostnadsfordel fører til at det ikke anses å foreligge diskriminering eller om kostnadsfordelen først kommer inn som «defence» etter læren om objektiv begrunnelse - slik at det dominerende foretaket vil ha bevisbyrden. I praksis vil dette sannsynligvis spille en mer begrenset rolle, idet det uansett vil være naturlig at det dominerende foretaket må dokumentere relevante gevinster. 


\section{Misbruksforbudet i konkurranseloven ( $\$$ 11) og dagligvaremarkedet}

På grunn av måten kontrakter forhandles på i bransjen, er det neppe riktig å foreta en diskrimineringsvurdering etter $\$ 11$ ned på enkeltproduktnivå, med mindre det nettopp er enkeltprodukter som utgjør hoveddelen av kontraktsforholdet. Der det forhandles om en portefølje i den forstand at produktene ses i sammenheng, vil det gi liten mening å sammenligne vilkår for enkeltprodukter. På dette punktet synes en mer helhetlig tilnærming til forholdet mellom leverandør og kunde å være fornuftig, jf. den danske Arla-saken:

For at afdække om Arla Foods rabatter og tilskud diskriminerer mellem de enkelte detailhandelskæder, er det derfor nødvendigt at sammenholde den umiddelbart skæve fordeling af de samlede rabatter og tilskud mellem kæderne med omfanget og arten af de ydelser, som Arla Foods leverer til de enkelte kæder. ${ }^{62}$

Som påpekt ovenfor forhandles priser som rabatter av G-pris eller D-pris. Ulikheter i forhandlingsstyrke vil gi seg utslag i ulike rabattsatser. Slike ulikheter vil typisk være avhengig av forhandlingsstyrke og forhandlingsdyktighet fra kjedene, og dersom rabattene er knyttet til volum, vil slike ulikheter ikke i seg selv representere diskriminering. (Med mindre rabattordningene er utformet på en diskriminerende måte.)

Samtidig er ikke rabattstrukturen nødvendigvis lik for hver enkelt kjede, hvilket i seg selv kan forsterke ulikheter. Rabattstrukturen dikteres av kjedene. Forskjellen mellom rabatter på G-pris vs. D-pris vil for eksempel kunne føre til en reelt sett ulik prisutvikling mellom kjedene ved økninger i leverandørens listepris. Dette skyldes at leverandøren vil være bundet av rabattene, men ikke vil ha herredømme over utviklingen i D-pris (som settes av kjeden). Samtidig vil innslaget av faste betalinger sannsynligvis variere mellom kjedene. 
Her blir det etter min oppfatning for enkelt å anvende diskrimineringstesten automatisk. Det er tale om ulike rabattmodeller som bestemmes av kjedene. Leverandørene vil ha begrenset mulighet til a påvirke det som kan betegnes som kjedenes netto salgsverdi (dvs. G-pris fratrukket alle rabatter). Samtidig kan det anføres at dominerende leverandører har et særskilt ansvar for å sørge for at konkurransen ikke begrenses, og at dette også må gjelde å sikre ikke-diskriminerende vilkår for sine kunder. En slik vurdering har imidlertid kun blitt benyttet overfor et dominerende foretaks plikt til å ivareta «restkonkurransen» $\mathrm{i}$ markedet, dvs. en plikt til ikke å ekskludere like effektive konkurrenter. Vurdering må dessuten ta i betraktning dominerende foretaks rett til å beskytte legitime kommersielle interesser.

Det er vel etablert at det ikke vil frita et dominerende foretak fra ansvar etter $\S 11$ at det er kunden selv som har bedt om en avtale som innebærer misbruk. ${ }^{63}$ Det foreligger imidlertid, så langt jeg kjenner til, ikke praksis som bekrefter at dette gjelder automatisk også der kontrakten er forhandlet frem med en aktør med kjøpermakt. Det «særlige ansvaret» kan neppe strekkes så langt at leverandøren må avslutte kundeforholdet dersom man ikke kommer til enighet. På dette punktet kan det også argumenteres for at kundenes forhandlingsstyrke må komme inn i vurderingen av hvorvidt det faktisk dreier seg om «like tilfeller».

All den tid den omtalte rabattstrukturen og forhandlinger knyttet opp mot rabatter (og ikke listepris) fremstår som generell i bransjen, er det også et spørsmål om konkrete utslag kan tilskrives enkeltforetak som «misbruk». Snarere synes asymmetriske priser (dersom det representerer et reelt konkurransepolitisk problem), å kunne føres tilbake til en generell praksis som har utviklet seg i bransjen over år, og som ikke begrenser seg til enkelte dominerende leverandører men gjelder helt generelt - uavhengig av leverandørens størrelse og uavhengig av hvor stor andel av sin omsetning leverandøren har med den aktuelle kjeden. ${ }^{64}$

63 Sak 85/76 Hoffmann-La Roche \& Co. AG v Kommisjonen [1979] ECR 461 (ECLI:EU:C:1979:36), prem. 89 .

64 Konkurransetilsynets rapport gir heller ikke uttrykk for noen sammenheng mellom leverandørens markedsstyrke og graden av differensiering. 
Jf. ovenfor kreves det i en tradisjonell vurdering av annenlinjes prisdiskriminering også at den eller de diskriminerte påføres en konkurranseulempe. Konkurranseulempe kan ses på som en kostnadsulempe som påføres den som diskrimineres. Hvis det er tale om en dominerende leverandør som selger et identisk produkt til to aktører nedstrøms og diskrimineringen utgjør en vesentlig del av kostnadene og produktene videreselges, vil det foreligge en konkurranseulempe dersom forskjellen hindrer den diskriminerte i å foreta konkurransehandlinger overfor den favoriserte. Iht. EU-domstolens uttalelser i MEO vil vurderingen knytte seg til konkurranseulempe for en like effektiv aktør som den favoriserte. ${ }^{65}$ Det er ikke nødvendig å påvise konkrete vridninger i konkurransesituasjonen mellom foretak nedstrøms.

I det norske dagligvaremarkedet er det på det rene at innkjøpspris representerer $70-80 \%$ av totale kostnader. Nettopp graden av kostnadsdekning er i praksis fremhevet som en sentral faktor ved spørsmålet om konkurranseulempe. Det er imidlertid på det rene at den enkelte kjedes konkurransekraft ikke er knyttet til enkeltprodukter, men til «handlekurven», slik at en mulig konkurranseulempe ikke nødvendigvis kan knyttes opp til én bestemt leverandør.

Uansett kan det være vanskelig å anvende en tradisjonell tilnærming til diskriminering pga. de mange mulighetene som er til å kryssubsidiere mellom produkter. En egentlig konkurranseulempe i markedet oppstår neppe før det er tale om en systematisk diskriminering som gjennomføres av et flertall leverandører og som har likeartede effekter for de de forskjellige kjedene eller nykommere. For eksempel vil JM (rabatter som motytelse for såkalt felles markedsføring) på noen produkter kunne aggregeres og benyttes til å subsidiere sesongsalg på andre varer. Den reelle konkurransesituasjonen befinner seg dermed langt fra pris på enkeltprodukt. I slike tilfeller - som er situasjonen i norsk dagligvare - er det ikke slik at en konkurranseulempe vil «følge» produktet (like lite som rabatter gjør det), og i den store sammenheng må det betydelig diskriminering på et produkt med både høy verdi og volum for at forskjellsbehandlingen

65 Dette innebærer sannsynligvis at for eksempel et argument om at Rema 1000 ikke påføres en reell konkurranseulempe fordi de er mer effektive enn NorgesGruppen ikke er relevant. 
skal kunne gi en slik konkurranseulempe som er angitt i MEO. Satt på spissen vil enkeltleverandører verken ha «skadeevne» eller «årsaksevne». Akkurat som man i Arla-saken så hen til den totale rabatten på leverandørens produkter, vil man i vurderingen av konkurranseulempe måtte se på totaliteten i kundens videresalg.

Til dette kommer at kjeder og kjedehus har noe ulik praksis når det gjelder hvilke kampanjer som dekkes av den enkelte kjøpmann (samt at kjedene har ulike strukturer der noen, for eksempel Rema 1000, primært har frittstående kjøpmenn mens andre har kjedeeide butikker), og hvilke som dekkes sentralt og dermed typisk av felles markedsføringsmidler (JM). Med en slik forutsetning, der asymmetrien er systematisk mellom samtlige leverandører, blir det vanskelig å henføre en konkurranseulempe til dominerende enkeltleverandørers adferd i markedet. Snarere representerer problemstillingen et bransjeproblem knyttet til rabattstrukturer og måten kontrakter forhandles på.

Dersom hele eller store deler av leverandørsiden systematisk diskriminerer (slik at diskriminering gjelder en betydelig del av verdiene), er det klart at den kumulative effekten vil kunne være en relevant konkurranseulempe ${ }^{66}$ Spørsmålet da blir hvorvidt dominerende enkeltleverandørers årsaksbidrag er tilstrekkelig til å etablere et misbruk. Svaret er usikkert. Under krrl. $₫ 10$ er det veletablert at en avtale vil kunne falle innenfor forbudet på bakgrunn av at den bidrar til en kumulativ effekt sammen med lignende avtaler. Et tilsvarende resonnement kan ikke overføres automatisk til misbruksforbudet. Klart nok vil et dominerende foretak være ansvarlig for ikke å misbruke sin dominerende stilling innenfor den strukturen markedet har. Spørsmålet her er imidlertid hvorvidt et enkelt foretak vil kunne misbruke sin dominerende stilling ved - kanskje marginalt - å bidra til en samlet konkurranseulempe skapt av et kollektiv av både dominerende og ikke-dominerende leverandører, og der den utløsende faktoren vil være den sterkeste kjedens evne til å oppnå best vilkår i forhandlingene (sannsynligvis som en kombinasjon

Konkurransetilsynets kartlegging, som omfattet 16 leverandører, viste at 14 av disse ga NorgesGruppen bedre betingelser, se https://konkurransetilsynet.no/wp-content/uploads/2019/11/ Rapport-om-innkjøpsbetingelser_2019.pdf. To leverandører ga NorgesGruppen dårligere betingelser. 
av forhandlingsdyktighet og -makt). Også under misbruksforbudet må det oppstilles et krav om årsakssammenheng mellom adferden som karakteriseres som misbruk og relevante skadevirkninger. ${ }^{67}$

Rettslig sett må spørsmålet om dominerende aktørers bidrag til en samlet konkurranseulempe, der leverandøren presses av en aktør med kjøpermakt til å innvilge bedre betingelser, anses som uavklart. Klart nok kan det argumenteres med at dominerende foretak har et særlig ansvar for ikke å begrense konkurransen, og at foretaket da også må søke å ivareta konkurransen på markedet selv om det er andre foretaks adferdsmessige (og ikke strukturelle) forhold som gjør markedet sårbart for ytterligere bidrag til en konkurranseskadelig eller -vridende effekt. Et slikt resonnement setter imidlertid få skranker for dominerende foretaks ansvar. I ytterste konsekvens kunne man tenkt seg at en dominerende leverandør måtte drive omvendt diskriminering for å motvirke en konkurranseulempe skapt av andre leverandører (som følge av den største kjedens forhandlingsmakt). Dette kan åpenbart ikke være riktig. Dersom prisene fra leverandørene systematisk er asymmetriske, og dette samlet sett skaper en konkurranseulempe for de minste kjedene, er det usikkert om dette vil innebære et misbruk fra enkeltaktører på leverandørsiden.

Drøftelsen viser således at strukturen i det norske dagligvaremarkedet, i kombinasjon med øvrige leverandørers og kjedenes adferd, gjør det usikkert om $₫ 11$ faktisk vil omfatte enkeltleverandørers asymmetriske priser. Særlig sentralt er at en relevant konkurranseulempe vanskelig kan føres tilbake til enkeltleverandørers priser, men til den kumulative effekten av samtlige leverandørers vilkår. Videre vil betydningen av kjøpermakt være sentral for vurderingen av hvorvidt det foreligger en relevant form for diskriminering.

Det kan endelig reises spørsmål om prisfordeler for NorgesGruppen faktisk «tas ut» i direkte konkurranse med andre kjeder, og hvis ikke, hvorfor. En mulig forklaring kan være at disse i tilfelle delvis dekker opp mindre effektiv drift og overetablering i detaljistleddet. Dette kan indikere at konkurransen fungerer dysfunksjonelt på kjedeleddet. Det er

67 Se nærmere Hjelmeng (2016), pkt. 3.1. Ved typer av adferd der det bare kreves at adferden er «egnet til» å begrense konkurransen e.l., kan dette ses på som et krav om at adferden konkret må ha årsaksevne i det konkrete tilfellet. 
imidlertid vanskelig å hevde at dette nøytraliserer en type konkurransefordel ift. andre kjeder. Dersom sviktende konkurranse nedstrøms (f.eks. i form av at det favoriserte foretaket velger ikke å konkurrere hardt overfor det diskriminerte fordi det er i dets interesse å beholde diskriminerte aktører i markedet snarere enn å slippe til nykommere), gjør at det diskriminerte foretaket vil overleve i markedet, innebærer dette likevel en konkurranseulempe siden det diskriminerte foretaket settes ute av stand til å foreta konkurransehandlinger det ellers ville kunne gått inn på.

\section{Eget forbud mot prisdiskriminering?}

\section{Innledning}

Diskusjonen om et eget forbud mot prisdiskriminering reiser egentlig to spørsmål: om det lar seg gjøre å utforme en regel som er praktikabel, og dessuten hvilke effekter en regulering vil ha. I det følgende diskuteres først utfordringer knyttet til det å finne en praktikabel regel, med sammenligning til den amerikanske Robinson-Patman Act. Deretter drøftes mulige virkninger av et forbud.

\section{Praktisk gjennomføring}

Enhver regulering vil stå overfor i alle fall to utfordringer: hvilke varer som skal sammenliknes, og hva prisen for varen er. Samtidig vil det være flere variabler knyttet til kontraktsvilkårene, for eksempel varighet, kreditt og tilleggstjenester.

Disse utfordringene er svært tydelige i den amerikanske RobinsonPatman Act. $^{68}$ De sentrale delene av bestemmelsen lyder (mine understrekninger):

It shall be unlawful for any person engaged in commerce, in the course of such commerce, either directly or indirectly, to discriminate in price between different purchasers of commodities of like grade and quality, where either or any of the purchases involved in such discrimination are in commerce, where such commodities are sold for use, consumption, or resale within the United

68 15 U.S.C. $\$$ 13. Tilgjengelig her: http://codes.findlaw.com/us/title-15-commerce-and-trade/15usc-sect-13.html. 
States or any Territory thereof or the District of Columbia or any insular possession or other place under the jurisdiction of the United States, and where the effect of such discrimination may be substantially to lessen competition or tend to create a monopoly in any line of commerce, or to injure, destroy, or prevent competition with any person who either grants or knowingly receives the benefit of such discrimination, or with customers of either of them: Provided, That nothing herein contained shall prevent differentials which make only due allowance for differences in the cost of manufacture, sale, or delivery resulting from the differing methods or quantities in which such commodities are to such purchasers sold or delivered...

Iht. ordlyden forbyr loven prisdifferensiering eller prisulikhet, men inneholder noen tilleggsvilkår som gjør at forbudet ikke blir absolutt. ${ }^{69}$ Både kravet om konkurranseskade og «defensen» knyttet til kostnadsulikhet har imidlertid - i alle fall tidligere - blitt tolket slik at bestemmelsen har rammet svært vidt. Supreme Court har lagt til grunn at det også etter RPA kreves såkalt «antitrust injury», det vil si en eller annen form for skade på konkurransen. ${ }^{70}$ Dette kriteriet har imidlertid ikke blitt konsekvent anvendt i saker om «secondary line injury», det vil si nettopp der ulike kjøpere stilles ulikt i konkurransen.

Flere av vilkårene i bestemmelsen har gitt opphav til tvister for amerikanske domstoler. Dette gjelder for eksempel spørsmålet om hva som kan karakteriseres som «like grade and quality»?11 Fysiske ulikheter vil typisk føre til at produktene ikke er sammenlignbare. At produkter selges under ulike merkenavn, vil likevel ikke føre til at de automatisk anses som ulike. ${ }^{72}$ I senere praksis synes kriteriet å ha blitt noe oppmyket, eksempelvis har salg av egg til høy pris der kjøper kunne velge størrelse og leveringstidspunkt ikke blitt ansett sammenlignbart med salg til lavere pris der kjøper

69 Om konseptet diskriminering etter loven sier Hovenkamp (2016), s. 777 følgende: «The Act directly condemns price differences, and only indirectly and haphazardly reaches economic discrimination.»

70 J. TRUETT PAYNE CO. v. CHRYSLER MOTORS CORP., 451 U.S. 557, 564 (1981), og VOLVO TRUCKS NORTH AMERICA, INC. v. REEDER-SIMCO GMC, INC., (2006) No. 04-905 (January 10, 2006), flertallsvotumet pkt. II. Se nærmere Glick et al. (2015), s. 307.

71 Som påpekt av O’Donoghue Padilla (2013), s. 792, er RPA her snevrere enn den potensielle rekkevidden til det europeiske misbruksforbudet. Se Hovenkamp (2016), s. 781, med henvisning til FTC v. BORDEN, 383 U.S. 637 (1966). 
måtte akseptere tilbudt størrelse og leveringstidspunkt. ${ }^{73}$ Det er likevel ikke tvil om at tolkningen innebærer at identiske eller tilnærmet identiske produkter solgt under ulike merker (for eksempel merkenavn vs. egne merkevarer), vil kunne falle innenfor bestemmelsen.

Når det gjelder prisen, vil denne kunne reflektere andre elementer enn bare varekostnad, for eksempel distribusjons- og markedsføringstjenester. Dette er formulert som et spørsmål om det foreligger «funksjonelle rabatter» (sml. felles markedsføring/JM i norsk dagligvare). I Texaco v. Hasbrouck hadde bensinforhandlere klaget over at grossister fikk kjøpe bensin til lavere pris. Supreme Court ga sin tilslutning til at rabatter som «merely accords due recognition and reimbursement for actual marketing functions» ikke ble rammet av loven. ${ }^{74}$ På dette punktet kreves det imidlertid forholdsmessighet, det vil si at rabatten må være begrenset til reelle tjenester. ${ }^{75}$

Også «cost justification defence» har vært omstridt. Som utgangspunkt skulle denne kunne bringe loven i retning av et forbud mot økonomisk prisdiskriminering, det vil si at prisulikheter som gjenspeiler ulikheter i marginale kostnader knyttet til levering til ulike kunder ikke omfattes. Dette vilkåret i loven har imidlertid ikke blitt tolket slik, men tvert imot dithen at en leverandør har vært nødt til å påvise at lavere pris stod i et proporsjonalt forhold til lavere kostnader ved leveranse til kunden. ${ }^{76}$

Endelig vil et foretak kunne reise et såkalt «meeting competition» forsvar, det vil si at priskutt representerer legitime svar på konkurranse fra andre («was made in good faith to meet an equally low price of a competitor»), ikke rammes. I tidligere praksis ble det krevet faktisk kunnskap om lavere priser fra konkurrenter, noe som skapte utfordringer med hensyn til informasjonsdeling mellom konkurrenter. ${ }^{77}$ I senere praksis er dette myket opp, slik at det er tilstrekkelig at kunder påstår de kan oppnå lavere

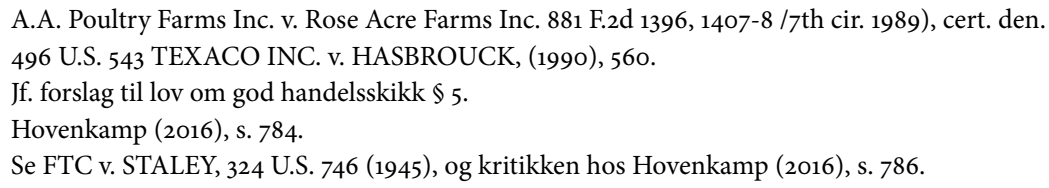


priser hos andre og selger ikke har noen plausibel grunn til å tvile på dette..$^{7}$

Denne gjennomgangen, samt behovet for flikking på bestemmelsen som rettspraksis dokumenterer, vitner om at det er betydelige praktiske utfordringer med å etablere en regel som faktisk virker etter sin hensikt.

Det er klart at et diskrimineringsforbud enkelt kan anvendes der det er tale om merkevarer i standardforpakninger, for eksempel Gilde 400 gr. kjøttdeig eller lettmelk i 1,75 liters kartonger. En sammenlikning blir vanskeligere der det er tale om avvikende forpakninger eller ulike kvaliteter, for eksempel der det er inngått avtaler om egne merkevarer eller særlige samarbeid som for eksempel NorgesGruppens «Folkets»-samarbeid med Nortura. En omregning til for eksempel kilopris vil ikke gjenspeile kommersielle forhold knyttet til salgspotensialet for ulike forpakningsstørrelser. Slik markedet fungerer, må det anses som meget vanskelig å komme frem til «omregningsfaktorer» på tvers av ulike kvaliteter eller varianter av tilsvarende produkter.

Spørsmålet om hva prisen egentlig er, fremstår som enda mer komplekst. I bransjen er det i tillegg til rene prosentvise rabatter bruk av det som i økonomisk teori omtales som «todelt tariff», det vil si en kombinasjon av faste beløp og en pris pr. enhet. I henhold til økonomisk teori er dette noe som kan stimulere konkurransen nedstrøms. ${ }^{79}$

Slike fastledd kan typisk representere en betaling for tjenester, da typisk i form av at kjedene yter markedsføringstjenester mot rabatter (JM/felles markedsføring). Å fastsette en verdi på slike tjenester, som varierer mellom kjeder og også mellom leverandører, vil gjøre det ytterligere vanskelig å komme frem til objektive sammenligningsgrunnlag for

\footnotetext{
78 Se UNITED STATES v. US GYPSUM, 438 U.S. 22 (1978) og FALLS CITY INDUSTRIES v. VANCO BEVERAGE, 46o U.S. 428 (1983). Se også Hovenkamp (2016) s. 787. 
pris. Alternativet ville selvsagt vært å forby denne typen rabatter, men det ble frarådet av Dagligvarelovutvalget som vurderte problemstillingen. ${ }^{8 \circ}$

I denne bransjen vil det også i mer begrenset utstrekning dreie seg om enkeltstående kjøp og salg av varer eller varepartier, men typisk om leveransekontrakter av i alle fall ett års varighet der pris justeres underveis. Også kontraktenes varighet vanskeliggjør en sammenlikning krone for krone og enhet for enhet. ${ }^{81}$

Konklusjonen er at det er svært vanskelig å operasjonalisere en tanke om «like priser» innenfor dagligvaremarkedet. En bestemmelse vil uansett ikke kunne fange opp eller regulere spørsmålet om hvilke varer som er sammenlignbare, eller spørsmålet om hva som er «prisen» for varen. En forpliktelse til like priser vil generere en rekke konflikter.

En bestemmelse som krever ikke-diskriminering eller like priser i kontrakter mellom leverandører og dagligvarekjeder, krever nødvendigvis en form for offentlig håndhevelse, da det er nødvendig å kjenne til innhold og vilkår i ulike kontrakter for å kunne vurdere om bestemmelsen overtres. Å basere håndhevelsen på private søksmål fremstår som tungvint og vanskelig, idet en misfornøyd kjøper dels vil måtte saksøke egen leverandør, dels vil måtte fremprovosere bevis om avtaler med andre kjøpere.

Det bør imidlertid utvises forsiktighet med å opprette et organ som risikerer å fungere som en «klagemur» for kjøpere som er misfornøyde med sine kontrakter. Liknende problemstillinger ble behandlet i forarbeidene til lov om god handelsskikk. Her sies det:

80 NOU 2013:6, s. 51-52: «Sett fra et samfunnsøkonomisk ståsted vil ikke-lineære kontrakter i utgangspunktet være effektive for den vertikale kjeden som helhet, og i mange tilfeller også for konsumentene. Dette er fordi denne typen fleksible kontrakter skiller de to hovedmålsettingene som aktørene i den vertikale kjeden har: i) sikre at detaljprisen settes på et nivå som maksimerer den vertikale kjedens fortjeneste, og ii) fordeler denne gevinsten mellom leverandøren og kjeden. Dersom ikke faste betalinger (som kan være mer eller mindre knyttet til motytelser) kan avtales, vil en lineær grossistpris måtte løse begge disse målsettingene. Normalt vil dette føre til ineffektiviteter som både leverandører, kjeder og konsumenter fort kan komme til å lide under.»

81 Også ved enkeltstående kjøp og salg vil det for øvrig være en utfordring å definere en grense for «nærhet i tid» mht. sammenligning av kjøp. Under RPA kreves det for eksempel at transaksjonene må være gjennomført innenfor «reasonable time», se Hovenkamp (2016), s. 780 med henvisninger. O’Donoghue og Padilla (2013), s. 795 oppstiller et tilsvarende krav under art. 102 TEUV. 
Det er grunn til å utvise en viss skepsis overfor et forslag om å opprette et sektorspesifikt tilsyn med oppgave å håndheve kontrakts-, markedsføringsog immaterialrettslovgivning, jf. Matkjedelovutvalgets forslag. Årsakene til dette er flere. For det første kan det lede til en unødig byråkratisering og rettsliggjøring av forhandlingsprosesser og kommersiell utvikling. For det andre vil det måtte foretas en lang rekke avklaringer av forholdet til andre myndigheters kompetanse, i særlig grad konkurransemyndighetene. For det tredje vil et offentlig tilsyn kunne bli en arena for strategisk atferd og rent-seeking. ${ }^{82}$

Dersom terskelen senkes for å klage til et organ, vil risikoen for misbruk $ø$ ke. Nedsiden ved å igangsette prosesser for å avdekke mulige overtredelser, vil være liten, mens oppsiden kan fremstå som stor dersom man har mistanke om at andre kunder oppnår bedre vilkår. Gitt de komplekse vurderingene som enhver slik regulering vil innebære vil dette nødvendigvis påfre leverandører som kommer i søkelyset betydelige kostnader. $^{83}$ Samtidig vil selve risikoen for slike prosesser måtte komme til å påvirke forhandlingsspillet.

\section{Mulige effekter}

Virkningen av en regulering er høyst usikker. ${ }^{84}$ At enkelte tar til orde for prislikhet, behøver heller ikke å bety godt nytt for forbrukerne; mindre kjeder og nettbutikker kan ha en interesse av like priser, mens nivået er mindre vesentlig. Selv om det ikke er empirisk belegg for at et diskrimineringsforbud alltid vil føre til at alle kunder får de samme dårlige vilkår, er det flere momenter som indikerer at gjennomsnittet blir dårligere.

Det kan tas utgangspunkt i en tenkt situasjon der man har to aktører som betaler en høyere pris, og én aktør som betaler en lavere. Et enkelt resonnement er da at et påbud om prislikhet vil gi alle aktører de sammen

\footnotetext{
82 NOU 2013:6 s. 108.

83 Uten sammenligning for øvrig kan det trekkes en parallell til Nasjonal Kommunikasjonsmyndighets håndhevelse av tilgangsforpliktelser etter ekomloven. Der genereres det en rekke klager, siden det ikke eksisterer noen nedside, og oppsiden ved å skaffe seg bedre vilkår i konkurransen er betydelig. (Uten at det med dette tas stilling til substansen i klagene.)

84 Se senest rapport fra en ekspertgruppe til Nærings- og fiskeridepartementet (17. januar 2020): Utredning om prisdiskriminering i dagligvarebransjen, av Tommy S. Gabrielsen, Espen R. Moen og Tore Nilssen (leder), tilgjengelig på https://www.regjeringen.no/no/dokumenter/ utredning-om-prisdiskriminering-i-dagligvarebransjen/id2686234/.
} 
gode vilkårene. Dette resonnementet overser likevel hvordan et slikt forbud vil påvirke incentivene og dynamikken i forhandlingene..$^{85}$

Dersom leverandøren vet at de vilkårene som fremforhandles med f.eks. den kjeden som har størst forhandlingsmakt og vil gjelde for alle andre aktører, vil dette selvsagt svekke incentivene til å gi en god pris, siden den største kjeden nå forhandler «på vegne av hele markedet». Krav om bedre betingelser kan imøtegås under henvisning til at andre kunder ikke har oppnådd bedre vilkår, og at det å imøtekomme kravet, vil føre til at de samme betingelser må tilbys andre. Dersom reguleringen utformes slik at de beste betingelsene blir gjeldende for alle, vil leverandøren selvsagt ha alle incitamenter til å unnga å gi etter i forhandlingene med kunden.

Samtidig vet den største kjeden at den ikke kan skaffe seg en konkurransefordel i forhandlingene, siden konkurrentene vil få den samme fordelen gjennom påbudet om like priser. Resultatet er at leverandørene vil stå hardere på sine krav, mens den kjeden som kanskje er mest forhandlingsdyktig ikke vil ha incentiver til å stå like hardt på sine. Det er mer sannsynlig at slike aktører vil søke å oppnå fordeler på andre måter som ikke inngår i det direkte sammenlikningsgrunnlaget, for eksempel gjennom integrasjon med leverandører eller økt satsning på egne merkevarer.

Dessuten vil de øvrige kjedene vite at de alltid vil få like gode betingelser som konkurrenten, og dermed er det liten grunn til å bruke mye ressurser på å forbedre sine egne (og konkurrenters) betingelser. Poenget er at et forbud mot prisdiskriminering vil fjerne innkjøpspris som en konkurransefaktor for dagligvarekjedene; det blir ikke lenger mulig å oppnå en konkurransefordel gjennom lavere innkjøpspriser. Dermed reduseres også incitamentet for kjedene til å forhandle om pris, siden den nedsettelsen man eventuelt forhandler seg frem til, automatisk vil bli gjort

85 Se Hjelmeng/von der Fehr (2018), s. 31, med henvisning til O’Brien (2014), s. 93: «[F]orbidding price discrimination raises the average wholesale price for a wide range of parameters that determine relative bargaining powers». O’Briens forutsetning er at det ikke foreligger realistiske «utsidealternativer» for kjeden, jf. straks nedenfor. 
gjeldende for de andre kjedene også. Dette indikerer at et forbud mot prisdiskriminering vil ha en prisdrivende effekt. ${ }^{86}$

Det er videre et spørsmål hvordan prislikhet vil påvirke konkurransen mellom kjedene. Det norske markedet er allerede gjennomsiktig, og dersom innkjøpsprisene blir like (slik at alle kjenner hverandres varekostnader), kan dette ytterligere bidra til å legge til rette for koordinerte virkninger.

Selv om det ikke entydig lar seg påvise at resultatet av en generell ikke-diskrimineringsregel alltid vil bli høyere priser, er det en tendens i de incitamenter og sammenhenger som er påpekt at prisene vil presses oppover. Økonomisk teori har da også jevnt over vært skeptisk til forbud mot prisdiskriming. Avhengig av hvilke forutsetninger man legger til grunn, er teorien imidlertid ikke fullstendig entydig om en prisdrivende effekt.

Nylig har f.eks. Foros og Kind, basert på arbeider av Katz og O’Brien, påvist at et forbud mot prisdiskriminering under spesielle omstendigheter vil ha som effekt at prisene blir lavere. ${ }^{87}$ Dette scenarioet bygger på visse forutsetninger: for det første at den største kjeden har et troverdig «utsidealternativ», dvs. har mulighet til å kjøpe fra andre kilder enn aktuell leverandør, ev. produsere selv. De artiklene man bygger på, altså Katz og O'Brien, forutsetter dessuten at kontraktene er lineære (kun pris pr. enhet og ikke faste betalinger). ${ }^{88}$

Det er neppe grunn til å trekke modellen i tvil, gitt at forutsetningene slår til. ${ }^{89}$ Det er likevel svært usikkert om disse forutsetningene kan leg-

86 Herbert Hovenkamp sier følgende om Robinson-Patman Act: «Low prices, not discriminatory prices, are the chief evil condemned by the Act. ... It was designed to protect small businesses from larger, more efficient businesses. A necessary result is higher consumer prices.» (Cit., s. 774).

87 Se Foros/Kind (2018), Katz (1987) og O’Brien (2014). Se også Foros/Kind (2019) for vurderinger under mer varierte forutsetninger.

88 Se Foros/Kind (2018), s. 14.

89 Når Foros og Kind avviser at størrelse i seg selv har betydning for vilkårene (Foros/Kind 2018, s. 11), fortjener dette likevel en kommentar. Deres resonnement går ut på at det selvsagt svir mer for en leverandør å miste en stor kunde enn en liten kunde, men at man i for liten utstrekning har sett på det motsatte: at det også svir for kjeden å kaste ut en leverandør. Disse effektene skal visstnok nøytralisere hverandre. Resonnementet er sannsynligvis bare valid dersom det gjelder «musthave» varemerker. Men dersom det først er slik, forutsetter dette markedsmakt på leverandørsiden, hvilket er inkonsistent med deres forutsetning om et troverdig «utsidealternativ». 
ges til grunn i norsk dagligvare..$^{90}$ For det første er ikke kontraktene i markedet entydig lineære. Faste betalinger (dvs. volumuavhengige betalinger f.eks. for joint marketing-tjenester), er fremdeles utbredt i bransjen. For det andre er det usikkert i hvilken utstrekning det foreligger slike realistiske utsidealternativer som modellen forutsetter. Dersom det tas for gitt at det foreligger asymmetriske priser i det norske markedet, og det innenfor en rekke produktkategorier ikke foreligger reelle utsidealternativer (f.eks. Coca-Cola (pga. branding), Grandiosa (pga. branding) eller Tine melk (pga. kapasitetsbegrensninger og samvirkemodell)), er det liten grunn til å tro at et generelt forbud mot prisdiskriminering kan forsvares etter modellen til Foros og Kind.

Foros og Kind baserer også sin diskusjon på at det foreligger en rasjonell forklaring på eksisterende asymmetri (de anfører to alternativer: ulikheter i diskonteringsfaktor hos kjedene (som avvises) og utsidealternativer). Slik Matkjedeutvalget dokumenterte, fremstår det imidlertid som at leverandørene frykter delisting uavhengig av om slike alternativer finnes, og dette indikerer at det kan være vanskelig å oppstille rasjonelle forklaringsmodeller på fenomener i bransjen. Og selv om det skulle finnes situasjoner der forutsetningene til Foros og Kind gjør seg gjeldende, må reguleringen for å treffe disse måtte differensieres tilsvarende, noe som nødvendigvis vil gjøre reguleringsobjektet til et bevegelig mål. Dette både fordi forutsetninger for økonomiske modeller vanskelig lar seg omforme til reguleringskriterier, dels fordi partene selv vil kunne påvirke forutsetningene (f.eks. lineære vs. ikke-lineære kontrakter). Risikoen for å regulere for bredt blir da overhengene.

Det er også grunn til å reise spørsmål om forutsetningen om et troverdig «utsidealternativ» $\mathrm{i}$ en situasjon der reguleringen er ment avgrenset til dominerende leverandører. Som påpekt ovenfor innebærer den rettslige definisjonen av dominans at foretaket er i stand til å opptre uavhengig av kunder, konkurrenter og forbrukere. Kommisjonen forklarer i sine retningslinjer for håndhevelsesprioriteringer under misbruksforbudet $\mathrm{i}$ EU-retten at

90 Se også diskusjonen i ekspertgrupperapporten av 17. januar 2020. 
This notion of independence is related to the degree of competitive constraint exerted on the undertaking in question. Dominance entails that these competitive constraints are not sufficiently effective and hence that the undertaking in question enjoys substantial market power over a period of time..$^{91}$

Dersom det først foreligger et realistisk utsidealternativ som gjør at kjeden kan skifte ut hele volumet fra leverandøren, vil det vanskelig kunne sies å foreligge en slik uavhengighet, og dermed heller ingen dominerende stilling. Foros og Kinds hypotese tilsier derfor paradoksalt nok at en gunstig effekt av et forbud mot prisdiskriminering bare vil inntre der det ikke foreligger dominans hos leverandør. Dette er imidlertid ikke overraskende; dersom foretaket først er dominerende vil det også ha muskler nok til å drive gjennom høyere priser for alle, mens det motsatte er tilfelle der leverandøren ikke har en slik posisjon. Om noe, tilsier arbeidet til Foros og Kind at man bør unngå å regulere dominerende foretaks prissetting, utover de tilfellene hvor en vurdering etter $\$ 11$ faktisk identifiserer en relevant konkurranseulempe..$^{2}$

\section{Oppsummering}

Fremstillingen har vist at det er vanskelig å anvende krrl. $\$ 11$ på mulig prisdiskriminering i det norske dagligvaremarkedet, noe som både skyldes vanskeligheter med sammenligning av kontrakter og varer, at konkurransen skjer på varekurvnivå (slik at vilkårene ikke følger varen), og at en eventuell konkurranseulempe ikke nødvendigvis kan henføres til én dominerende leverandør. Til dette kommer spørsmål om dominans gitt kjøpermakt.

En særregulering med krav om like priser vil ha usikre virkninger, men tendensen er en prisdrivende virkning gitt påvirkningen av forhandlingsincentiver. Selv om økonomisk teori indikerer at effekten under

91 Guidance on the Commission's enforcement priorities in applying Article 82 of the EC Treaty to abusive exclusionary conduct by dominant undertakings, OJ C 45, 24.2.2009, s. 7, pkt. 10.

92 Ev. at skadehypotesen må begrunnes i misbruk av kjøpermakt. Tilsvarende vil en regulering kunne begrenses til tilfeller som involverer kjøpermakt (enten den baseres på størrelse eller «utsidealternativer»), men dette vil være vanskelig å administrere, dels pga. utfordringene med å vurdere dette fra sak til sak, dels fordi reguleringen på et eller annet vis uansett må knyttes opp mot leverandør. 
gitte forutsetninger kan være lavere pris, er disse meget spesielle og neppe tilstede i det norske markedet. Til dette kommer at forutsetningen om et troverdig «utsidealternativ» tilsier at konklusjonen bare slår til der det ikke foreligger dominans.

\section{Regulering av tilgang til distribusjon}

Frem til ca. 2015 var det en hard kamp mellom kjeder og leverandører om distribusjonen av varer. Dette skyldtes primært to forhold: ønsket om kontroll på verdiskapningen i det leddet, og leverandørens ønske om å ha kontroll på varepåfylling i butikk. Leverandørene tapte denne kampen, og i dag er det vel bare Tine som fortsatt har egen distribusjon til butikk. For bryggeriene representerte omlegningen til PET-flasker (engangsflasker) spikeren i kisten.

I NOU 2011:4 lanserte Steensnæsutvalget en idé om et «non-profit» distribusjonsselskap. Dette ble mottatt med skepsis, og i etterpåklokskapens lys må man være glad for at dette aldri ble noe av. Dagligvarekjedene kniver i dag om å effektivisere distribusjonen, og kjedenes sentrallagre bygges også på en måte som gir betydelige miljøgevinster f.eks. gjennom bruk av robotteknologi og fornybar energi. Det er grunn til å være skeptisk til at en slik utvikling ville funnet sted innenfor en slik enhet som Steensnæsutvalget så for seg. Konkurranse driver også innovasjon.

Tilgang til distribusjon har imidlertid også en konkurransepolitisk side, siden nettopp etablering av et distribusjonsnettverk representerer en etableringshindring i markedet. På dette punktet er det grunn til å kritisere Konkurransetilsynets aksept av Coop/ICA-sammenslåingen, fordi med ICAs exit forsvant også et landsdekkende distribusjonsnettverk (og butikknettverk) som kunne representert et avgjørende «toehold» for en utenlandsk aktør. Dette aspektet ble imidlertid ikke vurdert av Konkurransetilsynet, som utelukkende fokuserte på lokal konkurranse mellom etablerte kjeder.

Slik situasjonen er i dag, er spørsmålet om regulering av tilgang til distribusjon kan bidra til å forbedre konkurransen i markedet. Svaret er sannsynligvis nei, av flere grunner. For det første er det riktignok slik at tilgang til et distribusjonsnettverk representerer en betydelig 
etableringshindring dersom man ønsker å etablere en fjerde kjedestruktur. Betydningen er sannsynligvis mindre dersom man ønsker å starte opp hjemlevering eller pick-up i tett befolkede områder. For det andre representerer den eksisterende butikktettheten i detaljistleddet sannsynligvis en mer alvorlig etableringshindring, noe som forsterkes av at attraktive lokasjoner allerede kontrolleres av dagligvaregrupperinger.

Krrl. $\$ 11$ vil i visse tilfeller kreve at konkurrenter gis tilgang til distribusjonssystemer. Terskelen er imidlertid høy, og det er vanskelig å se for seg at slik tilgang skulle kunne begrunnes i $\$ 11$ i det norske markedet. «The leading case» fra EU-domstolen her er fortsatt Bronner fra 1997. Saken gjaldt en tvist om tilgang til et distribusjonsnettverk for aviser i Østerrike. En konkurrent ønsket tilgang til nettverket for å få distribuert sine aviser. EU-domstolen avviste dette med flere argumenter:

In the first place, it is undisputed that other methods of distributing daily newspapers, such as by post and through sale in shops and at kiosks, even though they may be less advantageous for the distribution of certain newspapers, exist and are used by the publishers of those daily newspapers.

Moreover, it does not appear that there are any technical, legal or even economic obstacles capable of making it impossible, or even unreasonably difficult, for anyother publisher of daily newspapers to establish, alone or in cooperation with other publishers, its own nationwide home-delivery scheme and use it to distribute its own daily newspapers.

It should be emphasised in that respect that, in order to demonstrate that the creation of such a system is not a realistic potential alternative and that access to the existing system is therefore indispensable, it is not enough to argue that it is not economically viable by reason of the small circulation of the daily newspaper or newspapers to be distributed.

For such access to be capable of being regarded as indispensable, it would be necessary at the very least to establish, ..., that it is not economically viable to create a secondhome-delivery scheme for the distribution of daily newspapers with a circulation comparable to that of the daily newspapers distributed by the existing scheme. ${ }^{93}$

93 Sak C-7/97 Oscar Bronner (ECLI:EU:C:1998:569), prem. 43-46. 
Terskelen for å pålegge et foretak å gi en konkurrent tilgang til distribusjonsnettverket er iht. Domstolens praksis således høy. Dette omtales i konkurranseretten gjerne som «the essential facility doctrine», dvs. at tilgang må være absolutt nødvendig for tilgang til markedet, og at det samtidig ikke må være økonomisk lønnsomt («viable» i den engelske versjonen, «rentabelt» i den danske), å etablere et ytterligere nettverk.

Selv om det har skjedd betydelige effektiviseringer i de tre eksisterende kjedenes distribusjon, er det neppe grunnlag for å hevde at Bronner-vilkårene skulle være oppfylt i den forstand at en nykommer i markedet skulle kunne kreve tilgang til en av de etablerte kjedenes distribusjonsnettverk.

Spørsmålet er dermed om det er grunn til særreguleringer på dette punktet, f.eks. at den største aktøren innenfor distribusjon og logistikk (ASKO) skulle pålegges å distribuere varer også for kjeder/aktører utenfor NG-paraplyen. En slik løsning foreligger for så vidt allerede i dag, i og med at ASKO distribuerer varer til de få uavhengige aktørene som ennå er igjen. Konkurransepolitisk måtte en slik plikt ha innebåret en distribusjon på like vilkår. Dette ville imidlertid ikke etter $₫ 11$ ha betydd en plikt til å dele gunstigere innkjøpsvilkår med den nye aktøren. Slik bruk av krrl. $\$ 11$ vil dermed neppe representere en løsning på problemstillingen knyttet til tilgang til distribusjon.

Samtidig må ikke betydningen av kontroll med distribusjon overvurderes i en konkurransepolitisk kontekst. Transportnæringen i Norge ville sannsynligvis kunne håndtert de fleste behov for bulk-, kjøle-, og frysetransport. Ut fra et optimaliseringssynspunkt ville et system basert på et nettverk av kontraktører likevel neppe vært i stand til å realisere slike stordriftsfordeler som vi ser innenfor de eksisterende kjedenes systemer. Et effektivt logistikk- og distribusjonssystem må derfor anses for å representere en betydelig etableringshindring i markedet.

\section{Begrensninger på vertikale restriksjoner}

Et annet forslag er økte begrensninger på vertikale restriksjoner, dvs. ulike kontraktsklausuler avtalt mellom ulike ledd i distribusjonskjeden som legger begrensninger på adgang til eller vilkår for salg til andre. Eksempler er eksklusivavtaler, begrensninger på videresalg og 
restriksjoner på videresalgspris. Iht. det EØS-harmoniserte regelverket er slike restriksjoner iht. forskrift om vertikale restriksjoner tillatt, med unntak av bindinger av faste eller minimums videresalgspriser. ${ }^{94}$ Denne liberale tilnærmingen til vertikale restriksjoner i europeisk konkurranserett er et resultat av utviklingen i USA.95

Uten gruppefritaket ville vertikale restriksjoner vært gjenstand for en konkret vurdering av konkurranseskade og mulige effektivitetsgevinster. Gruppefritaket er også begrenset til aktører med maks. 30 \% markedsandel. Dersom det foreligger vertikale restriksjoner som ikke oppfyller de effektivitetskrav som ligger bak gruppefritaket, har Konkurransetilsynet kompetanse til å trekke dette tilbake, jf., krrl. $₫$ 10 fjerde ledd.

Det er usikkert om det benyttes særlig mange vertikale restriksjoner i det norske markedet. Muligens foreligger det slike overfor selveide detaljister (f.eks. Rema 10oos franchisetakere), men det er neppe grunn til å tro at disse representerer særlig mer enn f.eks. maksimalpriser (som er lovlig etter gruppefritaket). Jeg er heller ikke kjent med at det foreligger vertikale restriksjoner i forholdet mellom leverandører og kjeder. Skulle det gjøre det, f.eks. i form av bestevilkårsklausuler (at f.eks. andre kjeder ikke skal kunne få bedre vilkår), kan det likevel ligge et potensial i håndhevelse. ${ }^{96}$

Konkurransetilsynet kan trekke gruppefritaket tilbake dersom vertikale restriksjoner ikke er konsistente med effektivitetsmålsetningen som begrunner det generelle fritaket, jf. krrl. $\$$ 10 fjerde ledd: «Konkurransetilsynet kan bestemme at et gruppefritak ikke skal være anvendelig overfor bestemte foretak i den utstrekning avtaler, beslutninger og samordnet opptreden har virkninger som ikke er forenlige med tredje ledd.» Situasjonen vil da være at restriksjonene ikke lenger er automatisk fritatt, men at foretaket som opererer med dem selv å vise at vilkårene for det såkalte effektivitetsforsvaret i $\$ 10$ tredje ledd er oppfylt. Dersom dette ikke skulle

94 Forskrift nr. 898 av 21. juni 2010 om anvendelse av konkurranseloven $\$ 10$ tredje ledd på grupper av vertikale avtaler og samordnet opptreden.

95 Se Hjelmeng/Sørgard (2014), s. 567 ff.

96 Dette siste er likevel neppe et problem med mindre det foreligger en dominerende stilling på kjøpersiden, jf. ovenfor, og i tilfelle vil $\$ 11$ om misbruk kunne benyttes. 
slå til, vil restriksjonen være forbudt dersom den begrenser konkurransen iht. $\$ 10$ første ledd.

En strengere regulering av vertikale restriksjoner, f.eks. ved bruk av krrl. $\$ 14$, ville raskt komme i strid med det EØS-rettslige forbudet mot strengere nasjonal regulering av avtaler og samordnet praksis, jf. ovenfor s. 227.97

Det er neppe konkurransepolitiske grunner til å forvente at strengere tilnærming til vertikale restriksjoner vil løse konkurransepolitiske utfordringer i markedet. Dersom det foreligger mistanke om dette, vil et første skritt være at Konkurransetilsynet trekker gruppefritaket tilbake.

\section{Tak på markedsandeler}

Tak på markedsandeler kan tenkes i to relasjoner: enten ved at enkeltaktører forbys å vokse utover en viss størrelse, eller at det legges særskilte forpliktelser på foretak som oppnår et visst nivå på markedsandel. Dette kan f.eks. innebære å fiksere en bestemt grense for «dominerende stilling» dvs. innslagspunktet for misbruksforbudet. Dette har bl.a. vært gjort i Finland.

Det er en felles innvending mot begge idéer: Hvis foretak enten forbys å overskride én bestemt markedsandelsterskel eller vil møte et strengere regime, vil det miste incentivene til å konkurrere for å øke markedsandelen når det nærmer seg terskelen. Et forbud mot å overskride f.eks. en markedsandel på 30 \% betyr at et foretak som ligger på 29 \% vil konkurrere akkurat hardt nok til å beholde denne, men heller ikke mer. Effekten vil være som en slags kvotefordeling av markedet, som hvis aktørene selv hadde avtalt det ville vært et markant brudd med konkurranselovens kartellforbud. Et forbud mot å vokse over visse markedsandeler ville derfor vært drepen for konkurransen i markedet. Redusert konkurranse mellom de eksisterende aktørene og dermed økte priser kunne selvsagt gjort det mer attraktivt for nykommere å etablere seg. Dette ville imidlertid vært en gambling med forbrukernes interesser med et potensielt svært usikkert utkomme.

97 Se Gjendemsjø/Anchustegui (2017). 
$\AA ̊$ senke terskelen for dominans for å fange opp foretak som ikke når opp til definisjonen av dominerende foretak vil heller ikke bidra til å redusere mulig konkurranseskade i markedet. Dominerende stilling er etter $\$ 11$ formulert fleksibelt og nettopp knyttet til muligheten for å påføre konkurranseskade gjennom ensidig adferd. En terskel fiksert til en bestemt markedsandel (for eksempel $30 \%$ slik tilfellet er i Finland), ${ }^{98}$ vil nettopp risikere at handlenormen etter misbruksforbudet anvendes i en markedskontekst der det ikke er fare for skade på konkurransen. Dette vil ikke bare være sløsing med tilsynsressurser, men vil også kunne føre til at det slås ned på adferd som faktisk er effektiv for samfunnet.

\section{Vinnere, tapere og reguleringsbehovet}

Forhandlingene mellom kjeder og leverandører kan sies å være motoren i det norske dagligvaremarkedet. Det er der forbrukernes ønsker og preferanser spilles tilbake til leverandørene, det er der leverandørene kommer frem med sine nyvinninger, og det er der pris og andre vilkår fastsettes. Det er dermed også på denne arenaen at konkurransen mellom leverandørene viser seg.

Vellykkede forhandlinger representerer i utgangspunktet en vinn-vinn situasjon, fordi det er i begge partenes interesse å maksimere verdiskapningen. Dersom dette ikke fungerer, blir det to tapere ved forhandlingsbordet, fordi man ikke får ut det potensialet man ellers kunne. Om lov om god handelsskikk vil løse slike mulige problemer gjenstår å se, men lovens tanke er i alle fall å skape vinnere på begge sider av bordet. Fordelingen av verdiene som skapes skal og må det forhandles hardt om. I det spillet finnes det ikke optimale standarder, utover at helst ingen av partene bør være $100 \%$ fornøyde. Denne fordelingen griper da lov om handelsskikk heller ikke inn i.

Skal resultatene som skapes komme frem til forbrukerne, som skal være de egentlige vinnerne, må ikke gevinstene bli liggende igjen hos

98 Se https://www.kkv.fi/en/facts-and-advice/competition-affairs/legislation-and-guidelines/ competition-act/, $\$ 4$ a om «Dominant position in daily consumer goods trade». Se også Representantforslag til Stortinget 170 S - 2017-2018, s. 3. (https://www.stortinget.no/globalassets/pdf/ representantforslag/2017-2018/dok8-201718-170s.pdf). 
kjedene gjennom svak konkurranse dem imellom. Det foregående har gitt noen antydninger om at det $\mathrm{i}$ alle fall er noen utfordringer her. Konkurransen fremstår som skarp hvis man bare ser på detaljistleddet, men ser man kjedene under ett, kan det f.eks. reises spørsmål om mulige konkurransefordeler for enkeltkjeder virkelig kommer frem til forbruker. Er det tapere her, vil det være forbrukerne. Konkurransepolitisk finnes det egentlig ikke tapere når vi snakker om foretak. Utgangspunktet er at det er likegyldig hvem som konkurrerer, så lenge det faktisk er konkurranse.

Kapittelet her har ikke fokusert særlig på etableringshindringer og muligheten for nykommere. Det er klart nok store etableringsbarrierer i det norske dagligvaremarkedet, bl.a. knyttet til distribusjon, fysiske lokasjoner og det å få store nok volumer til å være konkurransedyktig på pris. Innkjøpssamarbeid med større kjeder har vært svaret både for Bunnpris og kolonial.no. Om løsningen er å pålegge leverandørene å gi alle like vilkår, er imidlertid høyst usikkert.

Dette bringer oss til reguleringsbehovet. En regulering må være basert på et klart definert problem, være målrettet og treffsikker, og ikke skape nye utfordringer og konflikter. Foreløpig er ikke det konkurransepolitiske problemet klart definert, og det foreligger derfor heller ingen åpenbare løsninger. 


\section{Referanser}

Anchustegui (2017): Ignacio Herrera Anchustegui: Buyer Power in EU Competition Law, disputasutgave, Bergen 2017.

Evensen/Sæveraas (2009): Harald Evensen og Eivind Sæveraas: Konkurranseloven og EØS-konkurranseloven med kommentarer, Oslo 2009.

Foros/Kind (2018): Øystein Foros og Hans Jarle Kind: Innkjøpspriser i dagligvaremarkedet. Samfunnsøkonomen, nr. 4, 2018.

Foros/Kind (2019): Øystein Foros og Hans Jarle Kind: Størrelsesbasert prisdiskriminering i det norske dagligvaremarkedet: Teori og terreng, Samfunnsøkonomen, nr. 5, 2019.

Friberg et al. (2020): Richard Friberg, Ivar Pettersen, Frode Steen og Simen A. Ulsaker (2020), Annerledeslandet Norge: butikktilgjengelighet og markedskonsentrasjon i Sverige og Norge, i Steen og Pettersen (red.): Mot bedre vitende $i$ norsk matsektor (2020).

Gabrielsen (2013): Tommy Staahl Gabrielsen: Lov om god handelsskikk

- En vurdering av virkninger for norske forbrukere av utvalgte forslag, i Pettersen (red.): Dagligvarehandel og mat, 2013.

Gjendemsjø/Anchustegui (2017): Ronny Gjendemsjø og Ignacio Herrera Anchustegui, Utredning av muligheten for å etablere en inngrepshjemmel mot ensidige handlinger i verdikjeden for mat som ikke rammes av konkurranseloven $\$ 11$, utredning for NFD, 2017. (https://www.regjeringen.no/contentassets/ eab200712f20412c997da6dee6ced5e6/utredning-av-inngrepshjemmel-motensidige-handlinger-1.pdf)

Glick et al. (2015): Glick, Mark A., David G. Mangum og Lara A. Swensen (2015), Towards a More Reasoned Application of the Robinson-Patman Act: A Holistic View Incorporating Principles of Law and Economics in Light of Congressional Intent. The Antitrust Bulletin, 60(4), 279-317.

Hjelmeng (2016): Erling Hjelmeng, Årsaksvurderinger i konkurranseretten, TfF 2016, s. 10-45.

Hjelmeng/von der Fehr (2018): Forbud mot prisdiskriminering - en overordnet og prinsipiell analyse, rapport utarbeidet for NorgesGruppen, 2018.

Hjelmeng/Sørgard (2014): Konkurransepolitikk - rettslig og økonomisk analyse, Bergen, 2014.

Hovenkamp (2016): Herbert Hovenkamp: Federal Antitrust Policy, The Law of Competition and its Practice, $5^{\text {th }}$ ed., 2016.

Katz (1987): Michael Katz: The Welfare Effects of Third-Degree Price Discrimination in Intermediate Goods Markets. American Economic Review, 77, 154-167. 
O'Brien (2014): Daniel P. O'Brien: The Welfare Effects of Third-Degree Price

Discrimination In Intermediate Good Markets: The Case of Bargaining. RAND Journal of Economics, 45, 92-115.

O’Donoghue/Padilla (2013): Robert O'Donoghue og Jorge Padilla: The Law and Economics of Article 102 TFEU, $2^{\text {nd }}$ ed., 2013.

von der Fehr (2013): Vertikale relasjoner - Noen prinsipielle betraktninger, i

Pettersen (red.): Dagligvarehandel og mat, NILF (2013), s. 117-134.

Whish/Bailey (2018): Richard Whish og David Bailey, Competition Law, $9^{\text {th }}$ ed., Oxford, 2018. 


\section{Forfatterbiografier}

Richard Friberg innehar Jacob Wallenbergs professorat ved Handelshögskolan i Stockholm. Hans forskning dreier seg først og fremst om internasjonal økonomi og empiriske studier av konkurranse. Han har også arbeidet med hvordan bedrifter håndterer risiko, som for eksempel hvordan valutakurser påvirker priser og markedsavgrensning. Flere av arbeidene analyserer dagligvare- og varehandelsmarkeder. Han har publisert bl.a. i American Economic Review, Journal of Finance og Marketing Science.

Erling Hjelmeng er professor ved Institutt for privatrett ved UiO og professor II ved Norges Handelshøyskole. Hjelmengs vitenskapelige produksjon har i hovedsak knyttet seg til spørsmål innenfor konkurranserett, EØS-rett og erstatningsrett. Store deler av produksjonen innenfor konkurranserett har skjedd i samarbeid med økonomer fra NHH og UiB. Et av hans hovedverk er Konkurransepolitikk - rettslig og økonomisk analyse, skrevet sammen med Lars Sørgard (2014). Han har også publisert artikler i tidsskrifter som Common Market Law Review, European Law Review og World Competition. Hjelmeng har ledet flere offentlige utvalg; utvalget som gjennomgikk konkurranseloven (2012), dagligvarelovutvalget (2013), markedsbalanseringsutvalget (2015) og utvalget som vurderte konkurranseforholdene mellom offentlige og private aktører i lys av EØSavtalens statsstøtteregler (2018).

Ivar Gaasland er førsteamanuensis i samfunnsøkonomi ved Handelshøyskolen BI. Hans spesialområde er handelspolitikk og næringsøkonomi, med spesiell vekt på jordbruk og matindustri. Han har ph.d. fra Universitetet i Bergen, og har tidligere vært forsker på Samfunns- og næringslivsforskning AS i Bergen.

Ivar Pettersen er seniorrådgiver ved Norsk institutt for bioøkonomi, NIBIO, og arbeider i dag med forskning og utredning innenfor verdikjeden for matvarer og moderne bioøkonomi. Han har bakgrunn fra 
forskning på markeds- og distribusjonsøkonomi, internasjonal økonomi og næringspolitikk, førsteamanuensstilling i matvaremarkeder og politikk ved Norges miljø- og biovitenskapelige universitet, internasjonal konsulentvirksomhet i McKinsey og internasjonalt økonomisk samarbeid. Fra 2004 til 2012 var han leder av Norsk institutt for landbruksøkonomisk forskning, en av forløperne til NIBIO.

Frode Steen er professor ved Institutt for samfunnsøkonomi ved Norges Handelshøyskole og Research Associate ved Centre for Economic Policy Research (CEPR). Han sitter i et gaveprofessorat finansiert gjennom NorgesGruppen og Norges forskningsråd og leder forskningsprosjektet FOOD, som analyserer ulike problemstillinger innenfor dagligvaremarkedet; herunder spesielt empiriske spørsmål relatert til konkurranse og produktivitet. Steen sine vitenskapelige arbeid har i hovedsak analysert spørsmål knyttet til konkurransestrategi og regulerings- og konkurransepolitikk. Han har publisert i kjente internasjonale tidsskrift som bl.a. American Economic Review, American Economic Journal: Microeconomics og The Economic Journal.

Magne Supphellen er professor i markedsøkonomi ved Institutt for strategi og ledelse ved Norges Handelshøyskole. Supphellen forsker og underviser innen temaområdene merkevarebygging, forbrukeratferd og kommersialisering av innovasjoner. Hans vitenskapelige arbeider er publisert i en rekke internasjonale tidsskrift, blant annet i Journal of Marketing, Journal of Consumer Psychology, Psychology and Marketing, Journal of Business Research og Public Opinion Quarterly. Supphellen er også aktiv som rådgiver og styrerepresentant for kommersielle og ideelle virksomheter.

Simen Ulsaker er postdoktor ved Institutt for samfunnsøkonomi ved Norges Handelshøyskole. Han er en del av forskningsprosjektet FOOD. I sine vitenskapelige arbeider har Ulsaker jobbet med konkurransepolitikk, handel og dagligvarer. Han har publisert forskningsarbeider i bl.a. American Economic Journal: Microeconomics, International Journal of Industrial Organization og Journal of Industrial Economics. 